FACULDADE DE FILOSOFIA LETRAS E CIÊNCIAS HUMANAS

\title{
Maquiavel e o trágico
}

\author{
Jean Gabriel Castro da Costa
}

Orientador: Prof. Dr. Cícero Romão Resende de Araújo

Tese apresentada ao Programa de Pós-

Graduação em Ciência Política do

Departamento de Ciência Política da

Faculdade de Filosofia, Letras e Ciências

Humanas da Universidade de São Paulo, para obtenção do título de Doutor em Ciência Política

\section{São Paulo}


“CORO [Sobre Dionísio]:

(...) Ao demo-deus,

filho de Zeus,

alegra a flor da festa,

apraz a Paz,

doadora-de-riqueza,

deusa nutriz de jovens.

Equânime,

ele concede ao rico a ao pobre

o júbilo antimágoa do vinho!

Mas odeia quem insiste,

à luz do dia

e à noite amiga,

no estar de mal com a vida.

Sábio é manter

o coração e a mente

longe do cerco de arrogantes.

O que o vulgo,

a massa mais depauperada

recolhe e acolhe

para mim é dádiva!"

(Eurípides. As Bacantes, 416-433)

"Mas como poderia a língua alemã, mesmo na prosa de um Lessing, imitar o tempo de Maquiavel, que no seu Príncipe nos faz respirar o ar fino e seco de Florença, e só consegue expor o assunto mais sério num indomável allegrissimo - talvez com maliciosa percepção artística do contraste que ousa: os pensamentos, difíceis, prolongados, duros, perigosos, e um tempo de galope e do bom humor mais caprichoso" (Nietzsche, Além do Bem e do Mal, aforismo 28) 


\section{Agradecimentos}

Agradeço ao Professor Cicero Araújo, por sua orientação atenta e estimulante e pela inspiração para percorrer os caminhos da teoria política, inspiração despertada ainda na graduação, por seus cursos instigantes e seu domínio da arte de ser professor.

À Professora Eunice Ostrensky e ao Professor Modesto Florenzano, pela leitura cuidadosa, as críticas e sugestões durante o exame de qualificação, fundamentais para a conclusão deste trabalho.

Ao Professor Fernando Limongi, por sua orientação valiosa durante a disciplina Seminário de Pesquisa e Tese. Ao Professor Adrian Gurza Lavalle, pelas ricas discussões surgidas em seu curso Teoria e Metodologia em Ciência Política e suas observações sobre o projeto deste trabalho. Ao Professor Rubem Barboza Filho, por sua leitura e comentários do paper relacionado a este trabalho, que foi apresentado no Encontro da ABCP de 2010.

Aos funcionários do Departamento de Ciência Política da USP, Rai, Márcia, Ana Maria, Vivian e Leonardo, por todo apoio prestado, sempre com competência e boa vontade.

Aos meus pais, José Castro e Maria Lenilce, pelo apoio, amor e formação, à Samara, pelo nosso amor constante, à minha querida filha Sophia, aos meus queridos irmãos, Carlos Eduardo e Ana Carolina. Agradeço a todos eles pelo apoio, formação, estímulos intelectuais e comunidade feliz. Agradeço aos meus grandes amigos, entre eles, Alex, Poline, Cecília, Tiago, Zé César, Tatiana, Luciano, Xande, Rodrigo, Clayton, Flávio, Manduco, Andréa, Akamine. Todos contribuíram para minha formação, para que eu conseguisse terminar este trabalho e para a alegria compartilhada.

À CAPES, pela bolsa de estudos concedida durante o doutorado. 


\title{
RESUMO
}

No Renascimento, o surgimento de um senso histórico que pensava os antigos em seus termos próprios, e a ideia de que seria preciso imitar os antigos, não resultaram em apenas uma posição humanista, qual seja, aquela tendência que foi predominante e que enfatizava o poder da liberdade humana sobre os caprichos da Fortuna. Também surgiu um ponto de vista trágico, no qual se insere Maquiavel e que possuirá importantes aspectos comuns com a recuperação do trágico entre os alemães do século XIX. O ponto de vista trágico levou Maquiavel a pensar a república como arena institucional-legal que permite um equilíbrio tenso e criativo entre forças sociais opostas, capaz de canalizar as ambições para o bem comum, fazendo com que a vitalidade expansiva dos cidadãos colabore para a vitalidade expansiva da república.

Palavras-chave: liberdade, Maquiavel, republicanismo, trágico

\begin{abstract}
In the Renaissance, the emergence both of a historical sense that made it possible to regard the Ancients according to their own standards, and of the notion that it would be necessary to emulate them resulted not only in a humanist attitude, i.e. the predominant disposition at that time, which emphasized the power of human freedom over the whims of Fortune. It also brought to light a tragic point of view, in which Machiavelli partakes, which will have important common traits with the retrieval of the tragic among the XIX century Germans. The tragic point of view lead Machiavelli to think the Republic as a legal-institutional arena which allows a taut and creative equilibrium between opposite social forces, capable of directing the aspirations for the common good, making the expansive vitality of the citizens collaborate with the expansive vitality of the Republic.
\end{abstract}

Keywords: freedom, Machiavelli, republicanism, tragic 


\section{SUMÁRIO}

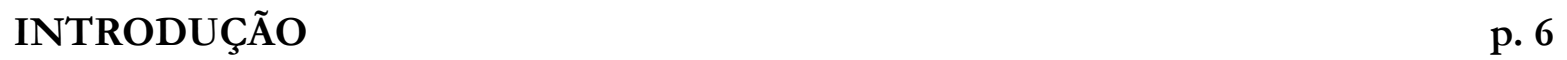

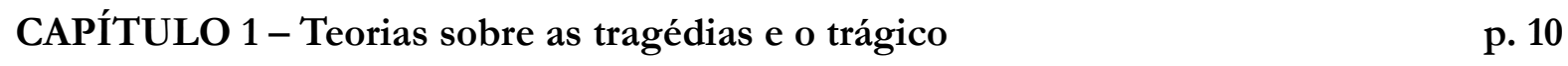

CAPÍTULO 2 - Fontes do ponto de vista trágico na cultura antiga p. 80

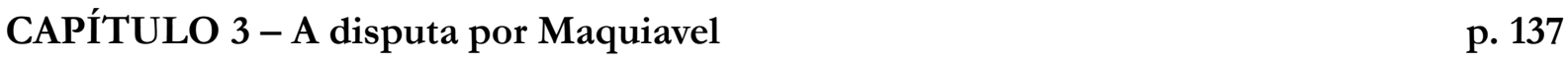

CAPÍTULO 4-Maquiavel e o ponto de vista trágico $\quad$ p. 172

$\begin{array}{ll}\text { REFERÊNCIAS BIBLIOGRÁFICAS } & \text { p. } 227\end{array}$ 


\section{INTRODUÇÃO}

Um Maquiavel trágico? Trágico em que sentido? Se for mesmo um autor trágico, em que isto contribui para a nossa compreensão de sua teoria política? Adicionemos ainda o tamanho do desafio, em se tratando de Maquiavel, autor com uma obra suficientemente aberta e instigante para produzir um intenso debate acadêmico entre diferentes, e por vezes opostas, correntes de interpretação. Para alguns, como Croce e Cassirer, Maquiavel seria, acima de tudo, um realista, um autor do pensamento estratégico, um técnico da política. Para os straussianos, Maquiavel seria mais bem caracterizado como um "professor do mal", um autor anti-cristão que pretendia demolir a "grande tradição" ocidental. Para os seguidores da "Cambridge School” e associados, Maquiavel seria um republicano, restando ainda saber se esse republicanismo era de origem aristotélica, como queria Pocock, ou neo-romano, como preferia Skinner. As pretensões normativas e preferências políticas dos intérpretes influem em suas escolhas e as diferentes interpretações reforçam uma ou outra alternativa teórico-política contemporânea, contribuindo para "esquentar" o debate, fazendo com que ele não seja de interesse apenas daqueles que se dedicam a produção de um conhecimento de "antiquário", como é pejorativamente dito por aqueles que são demasiado ansiosos para se interessar pelas nossas ligações com o passado.

O presente trabalho resultou da confluência de duas áreas de interesse: o pensamento trágico e a obra de Maquiavel. Nossa curiosidade inicial sobre a obra do florentino se deu por meio dos estudos sobre o republicanismo, especialmente, dos trabalhos de J.G.A Pocock e Quentin Skinner. A medida que prosseguia nas leituras, encontrava um Maquiavel mais original e intrigante, que não se enquadrava facilmente no nosso modo habitual de pensar. Tampouco parecia inserir-se de modo ortodoxo em seu próprio meio intelectual, o que já era percebido por Skinner. Mais leve em relação à posições anteriores, retornei aos trabalhos de Isaiah Berlin e Leo Strauss e encontrei interpretações que enfatizavam a originalidade de Maquiavel em relação ao 
seu próprio contexto e levantavam problemas que, para mim, aproximavam o florentino das questões que apareciam nas minhas leituras sobre as tragédias e o trágico, especialmente a partir da perspectiva de Nietzsche. A partir de então, resolvi investigar mais a obra do próprio Maquiavel e minhas suspeitas pareciam se confirmar: Maquiavel aparecia cada vez mais como um autêntico pensador trágico. Neste trabalho, procuro expor as ligações que encontrei entre Maquiavel e o trágico e tento mostrar que essa dimensão trágica do pensamento de Maquiavel pode nos ajudar a iluminar alguns impasses acerca da interpretação da obra do florentino.

No primeiro capítulo do presente trabalho, Teorias sobre a tragédia e sobre o trágico, o surgimento de um ponto de vista trágico, no Renascimento, é apresentado como um dos resultados intelectuais da intensificação do contato com as obras dos antigos, pensados em termos próprios, separados do contexto cristão, e pelo surgimento da ideia de que seria preciso imitar os antigos. Em seguida, procuramos expor as teorias sobre a tragédia e a filosofia trágica que surgem na Alemanha a partir de fins do século XVIII, movidas por uma "nostalgia da Grécia" e pela ideia de imitar os antigos. Dedicamos atenção especial ao trágico de Nietzsche, em razão de ter sido ele um leitor e admirador da obra de Maquiavel e de havermos encontrado proximidade entre suas posições.

O segundo capítulo procura as Fontes do ponto de vista trágico na cultura antiga, expondo aspectos dessa cultura que foram lidos pelos modernos em contextos de crise dos pressupostos da tradição judaico-cristã e os levaram a um ponto de vista trágico. A primeira parte deste capítulo trata da cosmologia trágica, da ideia de Caos, da compreensão trágica acerca dos limites do conhecimento humano, do agonismo antigo, do "naturalismo", elementos da liberdade trágica e a ideia de enfrentamento com o destino. Em seguida, procuramos contextualizar esses elementos que foram apresentados na história das cidades-estado gregas no momento em que começaram as encenações de tragédias. Nesse momento, a tragédia é pensada como uma terceira 
via entre a ética heroica da poesia épica e o racionalismo moral. Por fim, apresentamos as críticas de Platão ao trágico e a análise de Aristóteles sobre as tragédias.

No terceiro capítulo, A disputa por Maquiavel, procuramos expor algumas posições do debate contemporâneo em torno da obra de Maquiavel. Apresentamos em linhas gerais as interpretações de Pocock, Hans Baron, Najemy, Hirschmann, Skinner, McCormick e Leo Strauss. Tentamos mostrar aspectos relevantes dessas posições e como elas nos permitem negar ou defender a existência da dimensão trágica do pensamento de Maquiavel. Expusemos o debate entre Pocock, Skinner e McCormick sobre o conceito de liberdade do florentino e levantamos problemas que acreditamos que podem ser iluminados pela explicitação do trágico em Maquiavel, especialmente em relação ao conceito de liberdade, visto que não estamos satisfeitos com a inclusão, sem mais, do florentino na concepção de liberdade como não-dominação e tampouco com sua inserção no paradigma de uma teoria da liberdade ligada a uma concepção desinteressada de vida boa. Por fim, resolvemos tentar tirar Leo Strauss do ostracismo, por acreditarmos que ele é um grande adversário, e sua leitura ainda tem muito a nos ensinar, desde que afastemos nossas pré-noções e procuremos desvendar sua intenção, por meio da análise do entrelaçamento entre os níveis esotéricos e exotéricos de seu discurso.

O quarto capítulo, Maquiavel e o ponto de vista trágico, começa com uma apresentação de alguns trabalhos que relacionaram Maquiavel com o trágico, em seguida apontamos os méritos e limitações deles. Depois, procuramos mostrar os aspectos trágicos do pensamento de Maquiavel, com destaque para: seus juízos não utilitários e não morais sobre a performance dos agentes e sua simpatia pelo lado derrotado em alguns conflitos; sua cosmologia trágica, segundo a qual nada é permanente no mundo, que move-se por uma luta entre forças e é marcado pela combinação entre necessidade e acaso; sua valorização positiva da grandeza, que aparece na sua preferência pelo modelo popular e expansivo da república romana, considerado melhor mesmo 
sendo definido por ele como menos duradouro que os modelos aristocráticos e contidos de Esparta e Veneza; o dionisismo na vida de Maquiavel, que aparece em suas biografias; sua preferência pela moralidade pagã; o conflito trágico entre bem e bem, visível no conflito entre virtude republicana e virtude moral, entre bem comum e virtudes cristãs; seu naturalismo e sua distância em relação à teoria do livre-arbítrio; sua noção das limitações trágicas da ação humana; seu vitalismo trágico e agonismo, que aparece em sua ideia de que a virtù precisa ser testada, na necessidade da refundação contínua e de seus efeitos catárticos, na visão da república como equilíbrio tenso entre forças sociais opostas e na ideia de liberdade como vitalidade expansiva, expansão que é sempre positiva e que requer a liberdade negativa como o seu instrumento, e, por fim, a ideia de que é necessária uma bela ilusão, uma religião cívica, como estimulante para a ação e para estilizar as vontades de um modo favorável ao bem comum.

Longe de pretender ter esgotado o assunto, nosso propósito foi levantar questões, tentar pensar em saídas para alguns problemas nas interpretações contemporâneas da obra do florentino e apresentar um Maquiavel que tem sido escondido, numa tentativa, talvez, de amansar seu pensamento subversivo, alegre e instigante. 


\section{CAPÍTULO 1 - TEORIAS SOBRE AS TRAGÉDIAS E O}

\section{TRÁGICO}

Uma filosofia trágica é obra dos modernos. ${ }^{1}$ Para os antigos, a tragédia era um gênero teatral, distinto da comédia, da poesia épica e da lírica. O "trágico" não era uma posição a se defender contra outra. Não era uma bandeira existencial, teórica, política, como se tornou no mundo moderno, especialmente a partir de Nietzsche, quando "o trágico" passou a representar uma alternativa à visão judaico-cristã do mundo - religiosa ou laica - e à metafísica que dominou a filosofia ocidental desde Platão. Tentaremos mostrar que Maquiavel foi um autor trágico nesse sentido moderno. A ruptura de Maquiavel com a filosofia metafísica e com o cristianismo, também sofreu influência de uma determinada leitura dos antigos, e também, como em Nietzsche, trata-se da leitura dos antigos desvinculados do platonismo, especialmente os poetas, como Homero, Hesíodo e os poetas trágicos, que eram os representantes por excelência da tradição cultural hegemônica nas cidades-estado gregas. Também profundamente enraizados neste universo cultural estavam os filósofos pré-socráticos, com destaque para Heráclito, e os historiadores Heródoto, Tucídides e Xenofonte. Os valores centrais desta cultura (pagã, heroica, "trágica”) também eram hegemônicos em Roma e aparecem nas obras de Virgílio, Ovídio e Horácio, assim como em historiadores como Salústio.

A filosofia de Platão expressava uma posição minoritária em relação à tradição cultural hegemônica em seu mundo. As posições de Platão e da Academia eram as posições de uma pequena elite intelectual, não eram amplamente partilhadas em seu tempo (FINLEY, 1983, p. 41;

\footnotetext{
1 "Há algo, sem dúvida, que podemos afirmar com inteira segurança: os gregos criaram a grande arte trágica e, com isso, realizaram uma das maiores façanhas no campo do espírito, mas não desenvolveram nenhuma teoria do trágico que tentasse ir além da plasmação deste no drama e chegasse a envolver a concepção do mundo como um todo". (LESKY, 2006, p. 27). Ver também: "Since Aristotle we have a poetics of tragedy, only since Schelling a philosophy of the tragic". (GOLDHILL, 2008, p. 52). A mesma avaliação encontramos em Szondi: "Desde Aristóteles, há uma poética da tragédia; apenas desde Schelling, uma filosofia do trágico” (SZONDI, 1961, p. 23). Ver também: (MACHADO, 2006).
} 
MOMIGLIANO, 2004, p. 54). Isto deve ser levado em conta quando nós modernos pensamos no que seria mais representativo "dos antigos". Destoavam do que era hegemônico na cultura popular antiga características que nós modernos em geral atribuímos como típicas dos antigos, como a teleologia, a busca pelo governo ideal, a subordinação da política ao mundo suprapolítico de uma moral transcendental, a defesa categórica da moderação, a sobrevalorização da alma e da razão, em detrimento do corpo e das paixões, a distinção entre essência e aparência, entre outros pontos mais próprios de alguns filósofos antigos do que da tradição antiga.

Se para os antigos a tragédia era apenas um gênero artístico e não uma filosofia a se defender contra outra, é apenas porque este gênero estava firmemente fundado na tradição cultural hegemônica de seu tempo. Portanto, não havia necessidade, para os poetas trágicos, de assumir uma posição polêmica, já que eram amplamente partilhados os pressupostos cosmológicos e normativos centrais e não-conscientes (não questionados) desta cultura, pressupostos que se manifestavam no teatro trágico. Platão, por defender posições minoritárias e novas, é que precisou assumir estilo polêmico e construir sua filosofia contra a tradição, embora utilizando, como não poderia deixar de ser, características da própria tradição que estava atacando, pois Platão também foi um homem de seu tempo, conhecia e citava Homero e também elaborava mitos, como a alegoria da caverna ${ }^{2}$.

O inverso ocorre entre os “trágicos modernos”, pois estes estão em posição minoritária no interior da cultura judaico-cristã, cujos pressupostos cosmológicos e normativos possuem mais afinidade com Platão e sua escola do que com a tradição cultural hegemônica do mundo antigo, que era pagã, heroica e "trágica". Por isso os trágicos modernos são frequentemente polêmicos e performáticos, pois se movem contra a cultura que é hegemônica em seu mundo. É de se

\footnotetext{
${ }^{2}$ Há controvérsias a respeito da crença de Platão na sua teoria da alma e no modo como usava os mitos. Alguns comentadores defendem que Platão não acreditava nesses mitos, mas os considerava "úteis" para a boa ordem da cidade. Quer dizer, tratavam-se de ensinamentos exotéricos destinados aos leigos, enquanto aos iniciados poderiam ser dispensáveis os mitos. (KAUFMANN, 1968, p. 10 e 22-23; GOLDHILL, 2008, p. 48). Não é toda mímesis que é condenada por Platão, a própria Politeia, constituição perfeita, é descrita por Platão como o drama mais belo e mais excelente por ser a mímesis da existência mais bela e excelente (PLATÃO. As Leis, VII, 603c)
} 
considerar também que, quando estes trágicos modernos buscam inspiração na tradição do mundo antigo, eles estão fazendo uma escolha consciente por determinados valores em detrimento de outros, enquanto os antigos seguiam estes valores de modo natural, e nesta escolha e apropriação dos antigos se produz algo novo, e não a simples retomada quixotesca de valores e ideais que morreram.

É por aí que podemos encontrar pistas para entender o aparente paradoxo de que autores tidos como os mais modernos sejam, ao mesmo tempo, autores que valorizam uma tradição mais antiga do que a de Platão, como é o caso de Maquiavel e Nietzsche. Mais "modernos" porque teriam rompido com aquilo que Leo Strauss chamou de "grande tradição", quer dizer, com os filósofos, em especial Platão, Aristóteles e os estoicos, e com a tradição bíblica judaico-cristã. Nos momentos de crise desta tradição, os trágicos modernos buscaram em uma tradição ainda mais antiga fontes de inspiração para uma alternativa ${ }^{3}$.

Foi em períodos de transformação social e cultural que as tragédias e o "trágico" apareceram com mais intensidade no mundo moderno. Como notou Raymond Williams, "As eras de crenças relativamente estáveis não produzem tragédias de intensidade", ao contrário, "seu solo comum é um período de quebra ou transformação de uma cultura importante" (WILLIAMS, 2001, p. 54). No Renascimento, período em que, procuraremos mostrar, Maquiavel assume um "ponto de vista trágico", as cidades-estado italianas viviam grave crise em virtude dos intensos conflitos civis e da dificuldade de concorrer com os Estados territoriais centralizados que se formavam na época. No plano cultural, a visão cristã tradicional, agostiniana, experimentava um abalo, acompanhado de um interesse pelas obras antigas,

\footnotetext{
${ }^{3} \mathrm{Na}$ introdução dos Discorsi, Maquiavel se pergunta porque os modernos não imitam a "antiga virtù", e, depois de ironicamente dizer que isso não se deve "à fraqueza à qual a atual religião conduziu o mundo", afirma que o motivo deve ser o desconhecimento das coisas antigas, então Maquiavel afirma que resolveu escrever os Discorsi para "afastar os homens desse erro", que consistia em desconhecer as coisas antigas e não imitar a antiga virtù. (MAQUIAVEL, 1519a, pp. 5-7). O trecho é comentado por Strauss como mais uma demonstração de antagonismo de Maquiavel com a "grande tradição". Strauss diz que Maquiavel recorreu "a mais antiga das antiguidades" contra os modernos, identificados por Maquiavel com os homens da "moderna religião" (cristianismo). STRAUSS, 1958, p. 37.
} 
pensadas, pela primeira vez, em seus termos próprios, isto é, entendidas como obras de um tempo cortado do presente, separado do contexto cristão.

A Alemanha do século XIX - onde o trágico será recuperado e surgirá, pela primeira vez, uma filosofia do trágico - também vivia um período de transformações sociais e de retomada no interesse pelas obras dos antigos. As origens do trágico na Alemanha remontam ao século XVIII, quando os alemães já viviam um considerável desenvolvimento da vida burguesa, mas as formações sociais anteriores ainda estavam presentes e o país estava longe de se unificar politicamente. Foi um período de efervescência artística e cultural e de uma busca pela identidade nacional. Nesse contexto, artistas e intelectuais se voltaram para os antigos, especialmente os gregos, procurando inspiração para a construção dessa identidade e de um novo ideal estético. Winckelmann, considerado o pai da história da arte, foi o primeiro grande expoente desse movimento, com a publicação de seu livro Reflexões sobre a imitação da arte grega na pintura e na escultura, em 1755.

\section{O ponto de vista trágico e o renascimento italiano}

É importante, para os nossos propósitos, situar melhor estes dois momentos em que um ponto de vista trágico aparece: o Renascimento italiano e a Alemanha do século XIX. Skinner nos fornece a chave para compreendermos em que consistiu a retomada dos clássicos no Renascimento italiano. Ele procura corrigir os exageros dos estudos anteriores sobre o Renascimento, que estabeleciam uma ruptura radical entre a Idade Média e a Renascença e consideravam a escolástica como sendo exclusivamente ligada à visão medieval do mundo. Skinner, seguindo a perspectiva inaugurada por Kristeller, nos mostra como a escolástica, ao descobrir as obras éticas e políticas de Aristóteles, traduzidas para o latim no século XIII, já começa um processo de distanciamento em relação ao agostinismo. 
Segundo Skinner, "logo se notou que a filosofia moral e política de Aristóteles questionava a fundo o agostinismo que então predominava na concepção do que seria uma vida política cristã", pois se Agostinho "representava a sociedade política como uma ordem determinada por Deus e imposta aos homens, decaídos, como remédio para seus pecados", a Política de Aristóteles, por sua vez, "trata a pólis como uma criação puramente humana, destinada a atender a fins estritamente mundanos", e, em Agostinho, a "sociedade política está subordinada a uma escatologia, que considera a vida do peregrino na Terra pouco mais que uma preparação para a vida por vir", enquanto Aristóteles "ao contrário, afirma no livro I da Política que a arte de 'viver e viver bem' na pólis é um ideal auto-suficiente, que não necessita de qualquer finalidade ulterior para adquirir sua plena significação" (SKINNER, 2000, p. 71).

Para Skinner, foi da maior importância para o "desenvolvimento da concepção moderna, leiga e naturalista da vida política" que não tivessem prosperado os sentimentos iniciais de hostilidade com que foi acolhida a redescoberta dos escritos morais e políticos de Aristóteles. Skinner enfatiza que, em vez dessa hostilidade inicial, fizeram-se esforços para reconciliar a concepção aristotélica com as preocupações mais "voltadas para o outro mundo", típicas do cristianismo agostiniano, esforço intelectual que teve como seu maior expoente, Santo Tomás de Aquino, com sua obra Suma Teológica, que pretendia oferecer uma "completa filosofia cristã" fundada em uma “integral aceitação do pensamento moral e político de Aristóteles” (SKINNER, 2000, p. 71).

Esse movimento intelectual provocado pela redescoberta das obras de Aristóteles se disseminou entre os escolásticos, nas novas ordens da Igreja (em especial entre os dominicanos), nos currículos escolásticos de algumas universidades como a de Paris, e nas escolas de direito e retórica. Skinner destaca o papel de Marsílio de Pádua na difusão do aristotelismo na Itália e defende que a escolástica já formulava então um discurso da liberdade para as cidades-estado 
italianas e já prepara o terreno para a concepção de liberdade do humanismo cívico, entendida como "independência e o autogoverno" e "igual oportunidade para participar ativamente dos negócios do governo" (SKINNER, 2000, p. 98-99).

O que queremos destacar nessa abordagem de Skinner é que o início do pensamento político moderno se deve a um afastamento da visão cristã tradicional, que era a agostiniana, ocorrido por meio da intensificação do contato dos europeus com as obras da cultura antiga. Esse contato já existia na Idade Média, entretanto, houve uma rápida expansão da informação material sobre o mundo antigo com as descobertas de textos que haviam permanecido no esquecimento durante séculos e com a tradução de obras gregas para o latim.

Seguindo os estudos de Panofsky, Skinner considera que o resultado mais importante da aquisição de tantos textos novos, que haviam sido escritos em uma sociedade tão diferente, foi que "os humanistas gradualmente começaram a adotar uma nova atitude em face do mundo antigo", pois, defende Skinner citando Panofsky, na "Idade Média nunca encontramos tentativa alguma de se abordar a cultura do mundo antigo em seus termos próprios", em vez disso ocorria o que Panofsky chamou de "princípio da disjunção", que consistia na mistura eclética e anacrônica entre elementos antigos e medievais-cristãos, que aparecia, por exemplo, na arquitetura e decoração, quando elementos gregos e romanos apareciam misturados e figurados como "barões" e "donzelas" em paisagens medievais e muitas vezes praticando rituais cristãos (SKINNER, 2000, p. 106).

No fim do Trezentos, a atitude em relação ao mundo antigo já era totalmente diferente, pois "o passado clássico era considerado, pela primeira vez, uma totalidade cortada do presente" (PANOFSKY, citado em SKINNER, 2000, p. 107) Para Skinner, "um novo senso de distanciamento histórico foi assim alcançado, dele resultando que a civilização da Roma antiga começou a ser vista como uma cultura completamente distinta, merecendo - e mesmo exigindo - 
ser reconstruída e apreciada, sempre que possível, em seus termos próprios”. (SKINNER, 2000, p. 107). Skinner destaca o papel de Petrarca nessa mudança, que foi o primeiro que "conseguiu superar a disjunção entre as fundações clássicas da Ars Dictaminis e os propósitos práticos que era seu principal intuito atender. Repelindo todas as tentativas de enquadrar as obras de Cicero nas tradições vigentes de instrução nas tradições vigentes de instrução nas artes retóricas" (SKINNER, 2000, P. 108). Petrarca foi, segundo Skinner, o primeiro a redescobrir o senso que Cicero tinha do papel da educação, cujo principal objetivo seria produzir o vir virtutis, o homem verdadeiramente viril, por meio do estudo de filosofia moral e da retórica antigas.

Para os humanistas, esses "estudos clássicos" constituiriam não apenas a única forma de escolaridade considerada adequada a um cavalheiro, mas também a melhor preparação possível para o seu ingresso na vida pública. Começa a se formar a concepção renascentista de homem, que, ao contrário da concepção agostiniana de homem decaído, afirmava que, por meio da educação adequada, o homem era capaz de alcançar a virtus e desenvolver seus talentos de modo "universal" - de modo a tornar-se um bom cortesão, letrado, guerreiro e artista - em vez de se restringir ao desenvolvimento de apenas uma especialidade técnica. Ainda que essa visão mais "otimista" do homem não significasse que os humanistas tivessem abandonado o cristianismo, segundo Skinner, "não pairam dúvidas de que, ao restaurar o ideal clássico, eles efetuavam uma rejeição completa da tese agostiniana, então dominante, da natureza decaída do homem" (SKINNER, 2000, p. 114).

O otimismo renascentista acerca da liberdade e das capacidades do homem não deve, entretanto, ser exagerado, pois, ao mesmo tempo em que os humanistas recuperam a concepção clássica da virtus, e defendem a capacidade do homem de alcançá-la, recuperam também a noção clássica dos limites da ação humana, que aparece na importância que se atribuía ao papel da "Fortuna" entre os antigos. Apesar da dominação da Fortuna não ser considerada como 
inexorável, pois a Fortuna poderia se deixar seduzir pelo homem de "autêntica virtus", não haveria, entretanto, nenhuma garantia a priori de sucesso nessa empreitada, de modo que a arbitrariedade da Fortuna não poderia ser de todo eliminada ou controlada. Essa recuperação do papel da Fortuna, do arbitrário na vida humana, representou mais uma ruptura com o cristianismo agostiniano, pois, em seu ataque ao politeísmo, Santo Agostinho havia defendido que a deificação da Fortuna implicava uma negação do "caráter benfazejo da providência divina". Além disso, para Agostinho, o mundo inteiro era governado pela Providência, não tendo cabimento a pretensão do homem de pretender "esculpir o seu próprio destino" (SKINNER, 2000, p. 116). Os humanistas, por sua vez, recuperam a crença na capacidade do homem alcançar a virtù, desenvolvem a noção de que o homem é capaz de "esculpir o seu destino", e também a ideia de que o limite a esta pretensão não é nenhuma Providência, mas o "poder caprichoso da Fortuna" (SKINNER, 2000, P. 117).

Outra ruptura importante com o cristianismo agostiniano é a ideia, com origem na antiga cultura pagã, de que o mais alto bem que um homem de virtude (vir virtutis) pode alcançar é a "honra, glória e fama" mundanas. Como se sabe, a busca de glória foi considerada por Santo Agostinho como um pecado, pois "o amor ao louvor é um vício" e a busca de honra "é uma ideia pestilenta", e "não há genuína virtude quando a virtude está subordinada à glória humana" (Agostinho citado em SKINNER, 2000, p. 121). A glória para Agostinho estava reservada apenas a Deus. O homem decaído deveria, com humildade, se preocupar com a salvação da alma e não com a busca de glória neste mundo.

Skinner afirma que a ideia de um poder caprichoso da Fortuna levou alguns humanistas a um "extremo pessimismo" (SKINNER, 2000, p. 117), e cita como exemplo a obra de Poggio, $A$ miséria da condição humana, na qual Poggio, "lamentava a licença e poder da Fortuna sobre as coisas humanas". Mas, ao mesmo tempo, prossegue Skinner, “o retorno à imagem clássica dos 
predicados humanos" também teve o efeito de produzir nos humanistas "uma noção nova e instigante das capacidades do homem para lutar contra a maré da fortuna, para canalizar e dominar seu poder, e dessa maneira se tornar, pelo menos em certa medida, senhor do próprio destino" (SKINNER, Id). Essa tendência se tornou dominante entre os humanistas, pois “o motivo que melhor distingue a renascença", defende Skinner citando Garin, é "a convicção de que os homens podem utilizar sua virtus de modo a triunfar sobre os poderes da Fortuna" (SKINNER, 2000, p. 119).

Queremos destacar o fato de que Skinner notou que, embora a tendência predominante entre os humanistas fosse "otimista" a respeito do alcance da liberdade humana frente aos poderes da Fortuna, houve também um desenvolvimento mais "pessimista" a respeito da condição humana, tendência que apareceu, por exemplo, na obra de Poggio. Skinner também cita Maquiavel entre os que seriam "céticos" em relação à concepção mais "otimista" de homem predominante no Renascimento:

“A figura arrogante do gentil-homem renascentista continuou a valer como ideal, em que pese o ceticismo de Maquiavel, pelo menos até o final do século XVI" Grifos nossos. (SKINNER, 2000, p. 122)

O que queremos sugerir é que o aprofundamento do contato com as obras dos antigos e o desenvolvimento de um senso histórico que procurou pensar os antigos em seus termos próprios, separados do contexto cristão, não resultaram em apenas uma posição humanista, qual seja, aquela tendência que foi predominante, a "otimista", que enfatizava o poder da liberdade humana sobre os caprichos da Fortuna. Também surgiu uma tendência mais "pessimista" ou cética, que Skinner identificou em Poggio e Maquiavel. Esse outro desenvolvimento intelectual relaciona-se ao que chamamos de ponto de vista trágico, que consideramos estar presente em Maquiavel e que possuirá importantes aspectos comuns com a recuperação do trágico entre os alemães do século XIX. Estas semelhanças são possíveis em virtude do "ponto de vista trágico" surgir, em ambos os casos, em conjunturas sociais críticas associadas a um abalo ou crise nos pressupostos 
da visão judaico-cristã tradicional do cosmos e do homem, abalo que vem acompanhado, tanto no Renascimento como entre os alemães, por uma retomada do contato com as obras dos antigos, pensadas em termos próprios, e pela ideia de que seria preciso imitar os antigos.

A diferença na seleção de autores antigos ajuda a explicar os desenvolvimentos intelectuais diferentes. Se os humanistas cívicos em geral selecionaram como mais representativos daquilo que deveria ser imitado nos antigos os ensinamentos de Aristóteles, Cicero, os moralistas romanos e os retores, Maquiavel, por sua vez, preferirá os historiadores e poetas antigos, em detrimento dos filósofos e de Cícero, que seriam mais facilmente incorporáveis dentro da visão judaico-cristã do mundo. Esta diferença na seleção é semelhante àquela que encontraremos entre Hegel e Nietzsche, por exemplo, o primeiro preferindo entre os antigos Platão e Aristóteles, e o segundo preferindo Homero, Hesíodo, Heráclito, Ésquilo, os sofistas e Tucídides.

\section{As tragédias e o trágico no pensamento alemão}

Na Alemanha, a reflexão sobre o "trágico" teve sua origem com a obra de Winckelmann, que havia lançado aos seus contemporâneos, em 1755, a exigência: "O único meio de nos tornarmos grandes e, se possível, inimitáveis é imitar os antigos”. (Winckelmann, citado em MACHADO, 2006, p. 13). Machado aponta que Winckelmann foi o primeiro de uma série de alemães dominados pela "nostalgia da Grécia”. Segundo Machado:

“É na sequência desse movimento cultural de valorização do ideal grego de beleza e da necessidade de sua retomada pela arte alemã - movimento que se inicia com Winckelmann e tem Goethe como principal expoente - que nasce, principalmente a partir de Schelling, Hölderlin, e Hegel, colegas no seminário de Tübingen, uma reflexão sobre a essência do trágico, relativamente independente da forma da tragédia” (MACHADO, 2006, P. 22)

Essa reflexão sobre a "essência do trágico", dará origem a uma “filosofia do trágico", que será uma novidade dos alemães modernos. Entretanto, isso não significa que a "filosofia do 
trágico" não tenha nenhuma ligação com o gênero trágico ou com a "poética da tragédia". Entre os alemães, a "filosofia do trágico" começa a partir de uma reflexão sobre a Poética de Aristóteles, obra que já vinha balizando o debate europeu sobre as tragédias desde o Renascimento, ao lado da Arte Poética, de Horácio ${ }^{4}$. A primeira tradução latina da Poética de Aristóteles foi feita por Lorenzo Valla, em 1498, e impressa pela primeira vez em 1503 (MACHADO, 2006, p. 30). A partir do Renascimento tem início um longo debate sobre a Poética, sobre as tragédias e sobre o significado da catarse em Aristóteles ${ }^{5}$. Szondi também destaca que, embora distintas, a poética trágica e a filosofia do trágico estavam ligadas, e a filosofia do trágico "sobressai como uma ilha", nessa "poderosa zona de influência de Aristóteles, que não possui fronteiras nacionais ou temporais” (SZONDI, 1961, 24)

No Renascimento, surgiram tragédias modernas, algumas delas escritas e encenadas na Itália, mas sem grande repercussão. Na Inglaterra, com Shakespeare (1564-1616), é que a tragédia moderna assume maior importância. Na França do século XVII, destacaram-se Corneille (1606-1684) e Racine (1639-1699) como autores de tragédias. Entretanto, os franceses tendiam a produzir tragédias a partir de uma interpretação moral da análise aristotélica da tragédia - leitura que na verdade estava mais próxima à posição de Horácio - e interpretavam a catarse produzida pela tragédia como purgação moral. Para estes autores franceses do século XVII, a finalidade da tragédia era "melhorar os homens", livrando-os das paixões, finalidade muito diferente daquela pensada pelos poetas trágicos gregos ou mesmo da interpretação que Aristóteles fez das tragédias ${ }^{6}$.

\footnotetext{
${ }^{4}$ Essas duas obras eram bem diferentes a respeito das tragédias, pois para Horácio a tragédia tinha uma finalidade moral e a queda do herói seria fruto de uma falha moral, enquanto Aristóteles entendia a queda do herói como fruto de um erro (hamartia) que não possuía um sentido moral (discutiremos melhor este ponto na parte específica sobre Aristóteles).

${ }^{5}$ Machado menciona que em 1928 foi publicada uma Bibliografia da Poética, por Cooper e Gudeman, que catalogou 150 posições a respeito da catarse, do século XVI até 1928. MACHADO, 2006, p. 248.

${ }^{6}$ Sobre a tragédia moderna francesa escreve Machado: "Acontece que já podemos discernir na sua formulação ao menos duas diferenças em relação à aristotélica. Primeiro, uma concepção das paixões profundamente diversa do que são as emoções. Pois, na perspectiva cristã, que é a do classicismo francês, são as próprias paixões, e não apenas o seu excesso, que são consideradas más. Traduzindo pathos por passion, Corneille está transformando as emoções, pensadas por Aristóteles sem significado moral, em sentimentos irracionais que encarnam no amor profano e cegam
} 
Quando os alemães do século XVIII começam a elaborar uma dramaturgia nacional e moderna, já existiam os modelos inglês e francês de tragédia. Entretanto, como os alemães estavam fortemente vinculados ao projeto de Winckelmann, de imitar os gregos, tornaram-se críticos do modelo excessivamente moralizante dos franceses e reabilitaram Shakespeare. Lessing, crítico e dramaturgo que teve um papel fundamental na elaboração da moderna dramaturgia alemã, foi o primeiro a dar esse direcionamento. Segundo Machado, o texto mais esclarecedor sobre essa mudança de direção é a Dramaturgia de Hamburgo, livro publicado por Lessing em 1769. Lessing critica os franceses por haverem "distorcido as ideias de Aristóteles e serem por natureza profundamente não-clássicos e não-gregos” (MACHADO, 2006, p. 38).

Para Lessing, Aristóteles não pensava que a catarse produzida pela tragédia tivesse a função de nos livrar das paixões e emoções. A tragédia deveria suscitar a compaixão e o temor para nos purificar dessas emoções. Segundo Lessing, Aristóteles não escreve sobre outras emoções a serem purificadas e não diz que "purificar" ou "purgar" signifique eliminar essas emoções. Machado cita a Dramaturgia de Hamburgo:

"Visto que, para dizê-lo concisamente, esta purificação não consiste em nada mais do que na transformação das paixões em qualidades virtuosas - havendo porém em cada virtude, segundo o nosso filósofo, de um lado e de outro um extremo entre o qual a virtude se situa -, a tragédia, se é que deve transformar a nossa compaixão em virtude, precisa ser capaz de nos depurar de ambos os extremos da compaixão, o que também se refere ao temor. A compaixão trágica não deve, com respeito à compaixão, purificar apenas a alma daquele que sente compaixão demais, mas também daquele que sente de menos. O temor trágico não deve, com respeito ao temor, purificar apenas a alma daquele que não teme nenhum infortúnio, mas também a daquele ao qual todo infortúnio, até o mais remoto, até o mais improvável, deixa a alma angustiada. Do mesmo modo, a compaixão trágica, relativamente ao temor, deve remediar o que é demais e o que é de menos; assim como, por sua vez, o temor quando não são dominados. Pensado como paixão amorosa o pathos aristotélico torna-se em Corneille desregramento, uma paixão irracional perigosa ou imoral na medida em que ofusca a razão. Segundo, a ideia de que não se trata mais de purificar as paixões, mas de se purificar ou, para usar seu termo, se purgar das paixões. Mudança na maneira de conceber tanto o objeto da catarse quanto o seu próprio conceito, que é um bom exemplo de como a influência exercida pela Poética de Aristóteles sobre a teoria francesa do poema dramático é retomada de uma temática antiga em função de novos problemas, profundamente distanciada da teoria e da prática do teatro grego". (MACHADO, 2006, p. 33) 
trágico no que diz respeito à compaixão". (Lessing, citado em: MACHADO, 2006, p. 42) Grifos nossos.

Portanto, segundo Lessing, a catarse para Aristóteles não visava à eliminação das emoções, mas nos purgar do excesso, dos extremos, e assim transformar as emoções e paixões em qualidades virtuosas. A partir das reflexões de Lessing e dos problemas postos pela filosofia de Kant, tem início uma reflexão sobre o trágico como visão de mundo. Essa nova abordagem ganha autonomia em relação à discussão sobre o gênero trágico (finalidade da tragédia e efeitos da catarse), e, nessa busca pela "essência do trágico", de certa forma, se retoma a abordagem de Platão sobre as tragédias, que estava mais preocupada com o conteúdo do trágico do que com a discussão estética sobre o gênero trágico propriamente dito.

No contexto alemão do fim do século XVIII e início do XIX, a reflexão sobre o trágico apareceu como uma chave para resolver problemas colocados pela filosofia de Kant. Segundo Machado,

“em primeiro lugar, que a tragédia foi vista como modelo de uma solução ao que Kant chamou de 'antinomia', no segundo capítulo, 'A antinomia da razão pura', do Livro II da 'Dialética transcendental', da Crítica da razão pura; em segundo lugar, que o conflito trágico apresentado pela tragédia foi pensado a partir da teoria kantiana do sublime, exposta na 'Analítica do sublime' da Crítica da faculdade do juizo, por um deslocamento do privilégio que Kant concede à natureza, quando trata dos juízos de beleza e de sublime para o campo da arte" (MACHADO, 2006, p. 49) 7 .

A partir desse enquadramento surgiram as teorias do trágico de Schiller, Schelling, Hölderlin, Goethe, Hegel, Kierkegaard, Schopenhauer e Nietzsche. Para Schiller, o essencial do trágico era o conflito entre liberdade e necessidade que aparecia no sofrimento trágico e na representação da resistência ao sofrimento, para chamar a atenção à consciência da liberdade

\footnotetext{
${ }^{7}$ Terry Eagleton também considera que o "trágico" entre os alemães foi pensado como uma solução para as antinomias kantianas, como, por exemplo, a antinomia entre "liberdade" e "necessidade", e cita como exemplo a reflexão que Hegel fez sobre as tragédias: "It can be claimed that it is tragedy, rather than Kant, which supplies the solution. It is a solution which Hegel finds physically incarnate in Greek theatre, as the free activity of Spirit is distanced by masks, ritual, dance and Chorus into the anonymous image of destiny. Fate is just the outer garb of freedom, the expressionless features it turns to the world. If tragedy reconciles freedom and necessity, then it bridges the gap between pure and practical reason which the critical philosophy itself could never span". (EAGLETON, 2003, p. 119)
} 
interior de ânimo. Por esse motivo, Schiller preferia tragédias modernas como El Cid. A tragédia grega, para ele, deixava sempre a desejar em virtude "da importância que concede ao destino, isto é, por apresentar uma sujeição cega do homem à fatalidade, o que é humilhante para a liberdade e incompreensível para a razão" (MACHADO, 2006, p. 73).

Schiller recorrerá à teoria kantiana do sublime para entender o trágico. Tanto o belo como o sublime seriam expressões da liberdade, mas "no belo o sentimento de liberdade provém da harmonia, da consonância, entre os impulsos sensíveis e a lei da razão, entre a determinação natural e a determinação moral", já no caso do sublime, "o sentimento de liberdade se deve a que, havendo contradição entre os impulsos e a razão, os impulsos perdem toda influência sobre a legislação da razão: o caráter sublime se revela na adversidade. Como no caso de Jó, o personagem bíblico que, mesmo perdendo tudo, não perde a dignidade" (Schiller, citado em MACHADO, 2006, p. 66). Machado cita texto de Schiller em que o sublime é caracterizado em distinção com o "grande": "Grande é quem vence o que é pavoroso. Sublime é quem não o teme, mesmo vencido por ele... Grande foi Hércules, que realizou os 12 trabalhos. Sublime foi Prometeu, que, acorrentado no Cáucaso, não se arrependeu do seu ato e não admitiu o seu erro" (Schiller, citado em MACHADO, 2006, p. 70)

Enquanto Schiller preferia as tragédias modernas, pelo peso excessivo do "destino" nas tragédias antigas, Schelling, por sua vez, enxerga a importância dada ao destino nas tragédias gregas como uma homenagem à liberdade, pois, o que a tragédia apresentaria não seria uma aceitação do destino, mas um conflito entre liberdade e destino, pois o herói não sucumbe sem combate. O herói, atingido pelo destino, suporta voluntariamente a punição por um crime inevitável e quando morre prova essa liberdade com uma declaração de vontade livre. O herói enfrenta o destino e ao morrer perde a liberdade, mas ele escolheu o enfrentamento. O destino e a liberdade aparecem como vencedores e como vencidos. Segundo Szondi, o trágico está no centro 
do sistema de Schelling, cuja essência é a identidade entre liberdade e necessidade:

“Assim, todo o sistema de Schelling, cuja essência é a identidade de liberdade e necessidade, culmina em sua concepção do processo trágico como o restabelecimento dessa indiferença no conflito. Com isso o trágico é compreendido, mais uma vez, como um fenômeno dialético, pois a indiferença entre liberdade e necessidade só é possível pagando-se o preço de o vencedor ser ao mesmo tempo o vencido, e vice-versa". (SZONDI, 1961, p. 32)

Para Hegel, Schelling “caminha rápido demais para a harmonia", como sugeriu em prefácio da Fenomenologia do Espírito. Em Schelling já apareceria "de modo imediato" o “elemento dialético do trágico”, mas, para Hegel, era necessário elucidá-lo melhor. Para Szondi, é justamente "esse fator dialético que expõe o denominador comum das diversas definições idealistas e pós-idealistas do trágico e, com isso, constitui uma possível base para o seu conceito geral” (SZONDI, 1961, p. 81). Segundo Szondi, o elemento dialético já estava presente de modo implícito na discussão pré-filosófica sobre as tragédias, na "Poética de Aristóteles e nas obras de seus discípulos", o que se manifestaria na caracterização do conflito trágico como um conflito não em consequência de erros morais, mas de um erro cometido por pessoa de qualidade mediana, quer dizer, não se tratava de um conflito entre o bem e o mal, mas já se sugeria um conflito/contradição entre bem e bem e aparecia a ideia de que o bem pode se inverter, que o bem também "deve causar algum dano" (SZONDI, 1961, p. 81), quer dizer, o antagonismo, a contradição, estariam no centro das tragédias.

Hegel possui uma análise do gênero trágico, entendido como um gênero da poesia dramática (dividida em tragédia, comédia e drama), e esta era entendida como a síntese da poesia épica e da poesia lírica, quer dizer, a reunião do princípio épico da ação, considerada como "uma totalidade substancial de um espírito nacional" - tal como aparece na poesia épica - com a subjetividade, os "sentimentos interiores" da poesia lírica (Hegel, citado em: MACHADO, 2006, p. 125). No gênero trágico, especificamente, Hegel enxerga duas características principais: o conflito entre bem e bem e o conflito entre o que o herói faz com consciência e o 
que faz sem saber. Mas é o primeiro conflito, entre bem e bem, que recebe destaque nas análises de Hegel sobre as tragédias.

A peça Antígona, de Sófocles, seria um exemplo típico deste conflito entre dois direitos, ambos justos $^{8}$. Antígona, de acordo com o direito familiar e religioso, queria enterrar o seu irmão Polinices, morto na guerra. Entretanto, o rei Creonte, de acordo com o direito da cidade, havia ditado um decreto que proibia o enterro com honras de Polinices, pois ele havia traído a pátria, juntando-se ao inimigo na guerra contra sua própria terra natal. Direito contra direito. Duas potências éticas se enfrentam, família e religião por um lado, contra Estado e pátria por outro. Um conflito tenso, por serem duas dimensões importantes para um grego. É trágico o conflito entre duas opções boas, porque não tem solução simples ou não tem solução onde "os dois lados saiam ganhando", todo ganho envolveria uma perda. Antígona e Creonte estão certos, cada um representando uma potência ética diferente, mas ambos estão equivocados em virtude de sua unilateralidade. Esta unilateralidade não é superada preservando os dois lados, mas pela destruição mútua das unilateralidades. Antígona morre. Creonte é punido com a morte do filho e da mulher. Os indivíduos agindo por um pathos único tiveram que ser sacrificados para que a unilateralidade fosse abolida e se produzisse uma reconciliação, um retorno das forças éticas à harmonia. Mas até que ponto a destruição mútua significa reconciliação? Sempre o antagonismo é superado em uma unidade superior? Nesse aspecto, Goethe tinha avaliação diferente. Para ele, não há reconciliação no trágico: “Todo o trágico baseia-se em uma oposição irreconciliável [unausgleichbar]. Assim que surge ou se torna possível uma reconciliação [Ausgleichung], desaparece o trágico." (Goethe, citado em SZONDI, 1961, p. 48).

Para Hegel, o princípio da poesia dramática era o da contradição e reconciliação.

\footnotetext{
${ }^{8}$ Lesky e Kaufmann discordam da interpretação hegeliana de Antígona. Para eles, a peça seria claramente favorável a Antígona, e Creonte teria sido apresentado como tirano. Kaufmann considera que o conflito entre bem e bem destacado por Hegel como característico da tragédia se aplica melhor a outras peças trágicas como Oréstia, Prometeus, Hippolito e As Bacantes. Apenas em menor grau ajudaria a compreender a Antígona, Édipo Tirano e Filoctetes. KAUFMANN,1992, p. 204.
} 
Entretanto, como se sabe, esse não é apenas o princípio da poesia dramática, mas o princípio do próprio real. O real em processo entendido como autodivisão e autoconciliação do espírito, passando pelo movimento da eticidade, também ele um processo dialético de autodivisão e autoconciliação. Na Estética, Hegel expõe este processo:

"Nessa forma, a substância espiritual da vontade e da realização é o elemento ético... Portanto, tudo o que se exterioriza na objetividade real está submetido ao princípio da particularização; sendo assim, tanto os poderes éticos quanto o caráter ativo são diferenciados em relação a seu conteúdo e sua manifestação individual. Mas se, como reivindica a poesia dramática, essas potências particulares são incitadas a aparecer em atividade e se realizam como a meta determinada de um pathos humano que age, então sua harmonia é suprimida [aufgehoben] e elas aparecem em isolamento recíproco, umas contra as outras. A ação individual pretende então, sob determinadas circunstâncias, realizar uma meta ou um caráter que é unilateralmente isolado em sua completa determinação. De acordo com tais pressupostos, esse caráter necessariamente incitará o pathos oposto contra si, provocando conflitos inevitáveis. Assim, o trágico consiste originalmente no fato de que, em tal colisão, cada um dos lados opostos se justifica, e no entanto cada lado só é capaz de estabelecer o verdadeiro conteúdo positivo de sua meta e de seu caráter ao negar e violar o outro poder, igualmente justificado. Portanto, cada lado se torna culpado em sua eticidade" (Hegel na Estética, citado em SZONDI, 1961, p. 42)

O espírito se exterioriza na "objetividade real", e ao fazer isso necessariamente se particulariza. O universal nunca aparece em si na objetividade, mas sempre por meio do particular. O particular é sempre unilateral e incitará "o pathos oposto contra si”, a harmonia se quebra, surgem conflitos inevitáveis entre os particulares, e cada um dos opostos "se justifica", mas, ao mesmo tempo, cada um dos opostos, por sua unilateralidade, está errado. As unilateralidades não superam a situação preservando sua identidade, mas destruindo-se mutuamente, por meio da contradição que leva a superação da unilateralidade numa unidade superior. O processo se reinicia, contudo, caminha progressivamente para a reconciliação final do espírito consigo mesmo.

Quer dizer, a "trágica" autodivisão do espírito e os choques entre unilateralidades foram 
momentos necessários que serviam a um fim maior e se resolvem no tempo. Na "fenomenologia do espírito" os momentos da consciência são: certeza sensível ou "saber imediato", a percepção, o discernimento ou "entendimento" (Verstand), a autoconsciência, a razão (Vernunft) e o “espírito" (HEGEL, 2002). No plano do "espírito objetivo", a autodivisão e reconciliação ocorrem por meio do movimento da eticidade que comporta três momentos: a família (princípio da união, "comunidade", eticidade "substancial"), a sociedade civil-burguesa (princípio da desunião, da diferenciação individual, atomismo e liberdade subjetiva) e o Estado, que realizaria a "união da união com a desunião", a reconciliação do indivíduo com a comunidade, no máximo nível possível no plano do espírito objetivo (HEGEL, 1942). Esse movimento da eticidade corresponde a diferentes momentos históricos na Filosofia da História: O "mundo oriental", o "mundo grego", o "mundo romano" e o "mundo germânico", e este realizaria a reconciliação final, pois seu fim seria "a realização da verdade absoluta como a infinita autodeterminação da liberdade, que tem por conteúdo a sua própria forma absoluta” (HEGEL, 1999, p. 291).

O sentido desse processo histórico é a progressiva realização da liberdade desde o "despotismo oriental" até o mundo germânico protestante. Os choques entre particulares, as guerras, as mortes, o sofrimento, foram necessários para a realização de um fim maior: a liberdade. Quer dizer, a liberdade não é o oposto abstrato da necessidade, mas se realiza por meio da necessidade (um hegeliano de esquerda dirá mais tarde a "liberdade contém a necessidade enquanto superada"). Para Hegel, a posição de Kant era abstrata por pressupor que a liberdade exigiria um completo domínio da razão sobre os impulsos, interesses, paixões e determinações sociais (vida ética, costumes). Como isso é impossível, a liberdade permanecia inefetiva. Hegel quer tornar efetiva a ideia ética, quer realizar a liberdade no mundo, para tanto precisa reconciliar liberdade com necessidade, razão com sensibilidade ("Nada de grande se fez no mundo sem paixão"), de modo que as paixões e interesses particulares sirvam de instrumento para realizar o 
universal. Esse processo de realização do universal, da liberdade, da reconciliação do espírito consigo mesmo, é realizado de modo "trágico", pois a liberdade não se apresenta por si e de imediato, mas se realiza de modo progressivo por meio da contradição entre "particulares", o que ocorre frequentemente de modo violento. Essas contradições e sua necessidade constituem o elemento "trágico" do processo. Mas a ideia de uma reconciliação final, por sua vez, deve sua origem ao cristianismo, o que é constantemente reconhecido por Hegel desde suas obras de juventude até os seus últimos escritos. Não apenas a ideia de um fim tem origens na escatologia cristã, mas, em Hegel, a própria religião cristã é associada ao fim da história. Na Filosofia da História diz Hegel: "Essa relação para fora é, portanto, bem diversa da dos gregos e dos romanos, pois o mundo cristão é o mundo da perfeição; o princípio está cumprido, e com isso completou-se o fim dos tempos: a ideia não pode ver nada insatisfeito no cristianismo" ${ }^{" 9}$ Grifos nossos (HEGEL, 1999, p. 291).

Se retiramos o cristianismo de Hegel, retornamos a Heráclito: o fluxo eterno e inocente do devir por meio da luta de contrários, luta que exibe "a mais bela harmonia". Isto seria pagão demais para Hegel. Não é que o trágico seja incompatível com qualquer reconciliação ou consolação metafísica, muitos mencionam as peças de Ésquilo onde as colisões trágicas servem a um fim maior, a uma justiça divina. Algumas tragédias tinham final feliz. A épica era em grande medida "otimista", a Odisséia tinha final feliz. O que é incompatível com o trágico é a ideia de um fim, de uma interrupção final do fluxo, uma reconciliação definitiva.

Schopenhauer também pensou o trágico, mas já estava distante do idealismo de Schiller, Fichte, Schelling e Hegel. Schopenhauer rompe com "a teologia e com a imortalidade da alma" e começa uma denúncia da metafísica pela prioridade que atribui à razão, defendendo uma

\footnotetext{
${ }^{9}$ Há uma divergência entre a posição de Szondi e Deleuze. A dialética é vista por Szondi como característica do trágico. Para Deleuze, a dialética é oposta ao trágico em virtude da ideia de reconciliação final e do peso do negativo: "A dialética em geral não é uma visão trágica do mundo, mas ao contrário da morte da tragédia, a substituição da visão trágica por uma concepção teórica (com Sócrates), ou melhor ainda por uma concepção cristã (com Hegel)". (DELEUZE, 2001, p. 30)
} 
"subordinação da razão à intuição" e uma "subordinação da representação à vontade" (MACHADO, 2006, p. 170-1). Nesse movimento, Schopenhauer inicia um processo de "naturalização" da existência, pois a alma e o consciente perdem o status que possuíam entre os filósofos idealistas, que estavam empenhados "no velhíssimo erro" de procurar o "ser verdadeiro do homem no conhecimento consciente", com o objetivo de "tornar o homem o mais distinto possível do animal" (Schopenhauer, citado em: MACHADO, 2006, p. 171). O animal, o corpo ${ }^{10}$, assume um papel que não tinha a partir dessa maneira de ver a representação como fundada na vontade (abre-se o caminho para o modo de pensar da psicanálise). Nesse afastamento do idealismo, o trágico assume papel de destaque em sua filosofia. Para Schopenhauer, é a própria vida que é trágica:

“A vida de cada um de nós, se a abarcarmos no seu conjunto com um só olhar, se apenas considerarmos os traços marcantes, é uma verdadeira tragédia; mas quando é preciso, passo a passo, esgotá-la em pormenor, ela toma a aparência de uma comédia. Cada dia traz o seu trabalho, a sua preocupação; cada instante, o seu novo engano, cada semana o seu desejo, o seu temor; cada hora os seus desapontamentos, visto que o acaso está lá, sempre à espreita para fazer qualquer maldade: tudo isto são puras cenas cômicas. Mas os desejos nunca atendidos, a dor sempre gasta em vão, as esperanças quebradas por um destino impiedoso, os desenganos cruéis que compõem a vida inteira, o sofrimento que vai aumentando, e, na extremidade de tudo, a morte, eis o bastante para fazer uma tragédia. Dir-se-á que a fatalidade quer, na nossa existência, completar a tortura com o escárnio: ela coloca-lhe todas as dores da tragédia, mas, para não nos deixar ao menos a dignidade da personagem trágica, reduz-nos, nos pormenores da vida ao papel de bobo" (SCHOPENHAUER, 2001, parágrafo 58, p. 338).

Para Schopenhauer, o homem vive governado pela vontade, mas enquanto viver governado pela vontade não poderá ter felicidade duradoura, pois a vontade, entendida sem relação com o conceito racionalista de vontade, é o querer, o desejo. O desejo almeja um objeto,

\footnotetext{
${ }^{10}$ A importância causal do corpo já havia sido notada por Espinosa (conatus). Segundo Deleuze: "Espinosa abriu às ciências e à filosofia uma nova via: não sabemos sequer o que pode um corpo, dizia ele; falamos da consciência, e do espírito, tagarelamos sobre tudo isso, mas não sabemos do que um corpo é capaz, quais são as suas forças nem o que é que elas preparam. Nietzsche sabe que é chegada a hora: 'Estamos na fase em que a consciência se torna modesta'. Chamar a consciência à modéstia necessária, é tomá-la por aquilo que ela é: um sintoma" (DELEUZE, 2001, p. 61-2)
} 
a satisfação de uma necessidade, para com isso obter prazer, mas assim que alcança a satisfação, o desejo satisfeito cede lugar a outro desejo. A totalidade dos desejos nunca é satisfeita e a vontade é mais contrariada do que satisfeita. O que leva Schopenhauer a concluir que a vontade é uma fonte inesgotável de sofrimento. Quando o desejo é alcançado vem em seguida o tédio ou aborrecimento, quando não é alcançado tem-se sofrimento ${ }^{11}$. O conhecimento dessa "essência das coisas", que é a vontade e o sofrimento produzido por ela, leva a própria vontade a se negar, a nada querer ou a querer desligar-se do mundo fenomenal. Por isso Schopenhauer admira o asceta, seja ele hindu, budista ou cristão. O sofrimento é visto por Schopenhauer como necessário para se alcançar esse conhecimento que leva à negação da vontade. Por esse motivo, Schopenhauer considera que o papel da catarse produzida pelas encenações trágicas é levar o espectador a esse conhecimento que concluirá pela negação da vontade:

"É o antagonismo da vontade consigo mesma que entra em cena aqui [na tragédia], desdobrado da maneira mais completa, com todo o pavor desse conflito, no mais alto grau de sua objetividade [Objektität]. Esse antagonismo torna-se visível no sofrimento da humanidade que é produzido, em parte, pelo acaso e pelo erro, que aparecem como dominadores do mundo, personificados como o destino em sua perfídia, quase com a aparência de uma vontade deliberada. Por outro lado, esse antagonismo também é produzido pela própria humanidade, pelo entrecruzamento dos esforços voluntários dos indivíduos, por meio da maldade e da tolice da maioria. É uma única vontade que vive a aparece em todos eles, mas as suas manifestações lutam entre si e se despedaçam mutuamente... Tudo o que é trágico, não importa a forma como apareça, recebe o seu característico impulso para o sublime com o despontar do conhecimento de que o mundo e a vida não podem oferecer nenhum prazer verdadeiro, portanto não são dignos de nossa afeição. Nisso consiste o espírito trágico: ele nos leva, assim, à resignação". (Schopenhauer, citado em SZONDI, 1961, p. 52)

As tragédias são estimadas por Schopenhauer porque levariam à resignação, à nada querer, ao niilismo. Essa posição de Schopenhauer será duramente criticada por Nietzsche. É sintomático que Schopenhauer tivesse preferência pelas tragédias modernas, porque nas

\footnotetext{
11 "Portanto, a vida oscila, como um pêndulo, da direita para a esquerda, do sofrimento para o aborrecimento: estes são os dois elementos de que ela é feita, em suma" (SCHOPENHAUER, 2001, p. 327)
} 
tragédias gregas antigas dificilmente se encontrava o espírito de resignação, pois seus heróis em geral morriam desafiando o destino, os deuses, ou mesmo no caso de Édipo em colono, onde Édipo morre serenamente, não há propriamente resignação. Machado cita texto de Schopenhauer defendendo sua preferência pelas tragédias modernas:

"Enquanto os heróis trágicos da Antiguidade se submetiam com constância aos golpes inevitáveis do destino, a tragédia cristã nos dá o espetáculo da renúncia total à vontade de viver, do abandono alegre do mundo, na consciência de sua ausência de valor e de sua nulidade. Estimo a tragédia moderna bem superior à dos antigos. Shakespeare é bem maior do que Sófocles. Perto da Ifigênia de Goethe, poder-se-ia considerar a de Eurípides quase grosseira e comum. As Bacantes de Eurípides é uma obra medíocre e revoltante em favor dos padres pagãos” (SCHOPENHAUER, A. Citado em: MACHADO, 2006, p. 185)

O objetivo de Nietzsche será reabilitar o mundo, a vontade e a alegria de viver ${ }^{12}$, que Schopenhauer provavelmente consideraria algo "revoltante e em favor dos padres pagãos". Como é conhecido, Nietzsche começa sua reflexão sob forte influência da filosofia de Schopenhauer - o que marcará suas primeiras análises sobre o trágico -, entretanto, Nietzsche afasta-se de Schopenhauer, especialmente a partir de Humano, Demasiado Humano, obra de 1878. Mas mesmo em $O$ Nascimento da Tragédia, de 1872, já havia uma crítica à interpretação de Schopenhauer sobre finalidade da tragédia como sendo produzir resignação. Desde o princípio, Nietzsche posiciona-se contra a doutrina da negação da vontade. Segundo Szondi, já nas primeiras obras de Nietzsche é possível perceber que "em contraposição à dialética negativa de Schopenhauer, encontra-se em Nietzsche uma dialética positiva, que lembra a interpretação de Schelling nas Cartas” (SZONDI, 1961, p. 69). Para compreendermos o significado do trágico em Nietzsche, e as alterações e continuidades do trágico em sua filosofia, precisamos antes enfrentar alguns equívocos comuns a respeito de seu pensamento: 1) Nietzsche é pessimista. 2) Nietzsche é niilista 3) Nietzsche é um defensor da desmedida (hybris) dionisíaca e de uma visão

\footnotetext{
${ }^{12}$ No aforismo 338, de Gaia Ciência: "Eu quero fazê-los mais corajosos, mais resistentes, mais simples, mais alegres! Eu quero ensinar-lhes o que agora tão poucos entendem, e os pregadores da compaixão menos que todos: a partilha da alegria!" (NIETZSCHE, 1882, p. 228)
} 
"libertária”, de matiz "individualista". Tentemos primeiro nos desfazer dessas interpretações para entendermos o trágico em Nietzsche.

Nietzsche não é um pessimista à maneira de Schopenhauer, nem um otimista ao modo socrático. O seu "pessimismo" é algo bem distinto do que normalmente se entende pelo termo. Na Gaia Ciência, Nietzsche denomina sua posição como “pessimismo dionisíaco". Toda arte ou filosofia poderia ser vista como um remédio para o sofrimento, mas existiriam dois gêneros de sofrimento:

“Toda arte, toda filosofia pode ser vista como remédio e socorro, a serviço da vida que cresce e que luta: elas pressupõem sempre sofrimento e sofredores. Mas existem dois tipos de sofredores, os que sofrem de abundância de vida, que querem uma arte dionisíaca e também uma visão e compreensão trágica da vida - e depois os que sofrem de empobrecimento de vida, que buscam silêncio, quietude, mar liso, redenção de si, mediante a arte e o conhecimento, ou a embriaguez, o entorpecimento, a convulsão, a loucura" (NIETZSCHE, 1882, aforismo 370, p. 272)

Para Nietzsche, este último tipo de sofrimento levaria ao "pessimismo romântico", entendido por ele como "o último grande acontecimento no destino de nossa cultura" e que estaria expresso na filosofia de Schopenhauer e na música de Wagner. Entretanto, prossegue Nietzsche, ainda pode haver um outro pessimismo, derivado do sofrimento provocado pela abundância de vida, mas que não move uma acusação contra a vida:

"A este pessimismo do futuro - pois ele virá! Já o vejo vindo! - eu chamo de pessimismo dionisíaco" (NIETZSCHE, 1882, aforismo 370, p. 274)

Até que ponto um tal gênero de pessimismo, "por abundância de vida", que não acusa a vida, que não nega a vontade, ainda é um pessimismo? Certamente não se trata do pessimismo em seu significado habitual. Mas por que utilizar ainda o termo "pessimismo"? Talvez para se contrapor ao "otimismo socrático", que também levará à condenação deste mundo e da vida, também levará, segundo Nietzsche, ao niilismo. Quer dizer, a manutenção do termo “pessimismo" no Nietzsche pós-schopenhaueriano carrega uma importância retórica, serve para 
reforçar um antagonismo em relação a uma posição "otimista" que é vista como inimiga, na verdade vista como inimiga da vida.

No texto "O que devo aos antigos", do Crepúsculo dos Ídolos, de 1888, Nietzsche afirma que o trágico não tem nada a ver com pessimismo, algo que nem Aristóteles nem Schopenhauer teriam compreendido:

“A psicologia do orgiástico como sentimento transbordante de vida e força, no interior do qual mesmo a dor age como estimulante, deu-me a chave para o conceito do sentimento trágico, que foi mal compreendido tanto por Aristóteles como, sobretudo, por nossos pessimistas. A tragédia está tão longe de provar algo sobre o pessimismo dos helenos, no sentido de Schopenhauer, que deve ser considerada, isto sim, a decisiva rejeição e instância contrária dele. $\mathrm{O}$ dizer Sim à vida, mesmo em seus problemas mais duros e estranhos; a vontade de vida, alegrando-se da própria inesgotabilidade no sacrifício de seus mais elevados tipos - a isso chamei dionisíaco, nisso vislumbrei a ponte para a psicologia do poeta trágico. Não para livrar-se do pavor e da compaixão, não para purificar-se de um perigoso afeto mediante sua veemente descarga - assim o compreendeu Aristóteles -: mas para, além do pavor e da compaixão, ser em si mesmo o eterno prazer do vir a ser - esse prazer que traz em si também o prazer no destruir..." (NIETZSCHE, 1888, p. 106) Grifos nossos.

Ao invés de ser expressão de um pessimismo que nega a vida em virtude de seus sofrimentos, o trágico estaria ligado a um dionisíaco "dizer Sim à vida, mesmo em seus problemas mais duros e estranhos". Portanto, a questão do pessimismo/otimismo gira em torno do sofrimento e de como interpretar e tratar o sofrimento. Os desejos não satisfeitos, os revezes de todos os tipos, os acidentes, as doenças, a passagem do tempo e a mortalidade, em suma, o sofrimento na vida, pode levar a uma acusação contra a vida. Este modo de reagir ao sofrimento seria mais comum nos sábios ${ }^{13}$ do que entre os populares ${ }^{14}$ e seria um sintoma de decadência, de

13 "Em todos os tempos os grandes sábios sempre fizeram o mesmo juízo sobre a vida: ela não vale nada" (NIETZSCHE, 1888, p. 17)

${ }^{14}$ Nietzsche reconhece a origem popular do dionisismo e das tragédias: "O ditirambo é canto popular e, na verdade, principalmente das camadas inferiores. A tragédia sempre conservou um caráter puramente democrático, pois ela surgiu do povo" (NIETZSCHE, 1870, p. 56). Frequentemente Nietzsche contrasta a alegria inocente e corajosa do popular, da "gente miúda", com o niilismo cansado do sábio, como no aforismo 434 da Vontade de Poder: "Na práxis da vida, na paciência, na bondade e no mútuo encorajamento a gente miúda é superior a eles: esse é aproximadamente o juízo que Dostoiévski ou Tolstói reivindicam para seus mujiques: eles são mais filósofos na práxis, têm uma maneira mais corajosa de safar-se no necessário" (NIETZSCHE, 1906, p. 235) 
um enfraquecimento, de cansaço da vida. O cansaço leva à busca, a todo custo, da ausência de sofrimento. Para alcançar essa meta, seria necessário eliminar os riscos e neutralizar tudo aquilo que pode provocar sofrimento como a disputa, os instintos, as paixões, os desejos. Quer dizer, a ausência de sofrimento só poderia ser alcançada atacando as mesmas causas que produzem também alegria. Para Nietzsche, teria sido esse o remédio radical que Sócrates ofereceu contra o sofrimento: condenar este mundo do devir como mera aparência e afirmar que existe um outro mundo, o "mundo verdadeiro", eterno e perfeito, que podemos contemplar por meio da razão, e que, aqui, no mundo da aparência, seria preciso que a razão dominasse os instintos, paixões, desejos, pois estes provocam dor. Esse seria o sentido do "otimismo socrático": o sofrimento tem solução definitiva, pode ser extirpado pela razão.

Para Nietzsche, o maior "problema de Sócrates" não é que o "mundo verdadeiro" seja uma "fábula", mas sim que seja uma fábula nociva à "vida", porque o remédio oferecido por Sócrates foi um "remédio radical", representou uma hybris: a tirania da razão, em vez de um "equilíbrio entre os instintos". A busca pelo "mundo verdadeiro", a fanática "vontade de verdade", deu início ao niilismo, entendido como o processo progressivo de destruição dos mitos que culmina na conclusão de que o próprio "mundo verdadeiro" seria um mito ${ }^{15}$. A busca

\footnotetext{
${ }^{15}$ Tomando a linguagem do "nietzcheano" Max Weber, o "desencantamento do mundo" não é uma preferência, mas o resultado do "processo de racionalização": "E em nossos dias? Quem continua a acreditar - salvo algumas crianças grandes que encontramos justamente entre os especialistas - que os conhecimentos astronômicos, biológicos, físicos ou químicos poderiam ensinar-nos algo a propósito do sentido do mundo ou poderiam ajudar-nos a encontrar sinais de tal sentido, se é que ele existe? Se existem conhecimentos capazes de extirpar, até às raízes, a crença na existência de seja lá o que for que se pareça a uma significação do mundo, esses conhecimentos são exatamente os que se traduzem pelas ciências". (WEBER, 1997, p. 34.). O processo de racionalização era movido pela "vontade de verdade". Para Nietzsche, a vontade de verdade, por sua vez, movia-se por uma tentativa de negar o vir a ser em virtude de seus sofrimentos, do acaso, da morte. Quer dizer, a vontade de verdade movia-se pelo instinto do medo. Tema com o qual Adorno e Horkheimer abriram a sua Dialética do Esclarecimento: "No sentido mais amplo do progresso do pensamento, o esclarecimento tem perseguido sempre o objetivo de livrar os homens do medo e de investi-los na posição de senhores. Mas a terra totalmente esclarecida resplandece sob o signo de uma calamidade triunfal. O programa do esclarecimento era o desencantamento do mundo. Sua meta era dissolver os mitos e substituir a imaginação pelo saber.” . (ADORNO \& HORKHEIMER, 1985, p. 19) Parece-nos que estes frankfurtianos se inspiraram no aforismo 355 de Gaia Ciência: "Não mais que isto: algo estranho deve ser remetido a algo conhecido. E nós, filósofos - já entendemos mais do que isso, ao falar de conhecimento? (...) Não seria o instinto do medo que nos faz conhecer? E o júbilo dos que conhecem não seria o júbilo do sentimento de segurança reconquistado? ... Eis um filósofo que deu o mundo por 'conhecido', tendo-o remetido à 'ideia': não seria porque a 'ideia' lhe era tão familiar, tão habitual? Porque ele já a receava tão pouco? - Oh, que fácil satisfação a dos homens de conhecimento!" (NIETZSCHE, 1882, p. 250)
} 
fanática pela verdade chegou ao nada. Aqui nos aproximamos do segundo erro comum que mencionamos sobre Nietzsche: o de que ele seria niilista, quando, em verdade, trata-se do oposto, pois Nietzsche pretendia superar o niilismo. O niilismo não é uma alternativa que Nietzsche "escolhe", mas o resultado de um longo processo iniciado pelo "otimismo socrático" em sua pela busca pela Verdade, pelo "fundamento", busca que culminou, entre os europeus modernos, com a "morte do fundamento", a morte do "velho Deus" (NIETZSCHE, 1882, aforismo 343, p. 233).

No mundo dos europeus modernos esse processo atingiu seu ápice, mas isso não significa que o niilismo só tenha aparecido aí, que seja um fenômeno exclusivamente moderno. Nesse ponto concordamos com Rossi, quando escreve: "Rejeito a visão que faz do niilismo uma ancoragem exclusiva no mundo contemporâneo", pois o niilismo também teria aparecido em “determinadas épocas de crises estruturais, como são os casos da fragmentação da polis grega, da queda do Império Romano, da transição do Medievo ao Renascimento” (ROSSI, 2006, p. 330). O niilismo é o resultado do projeto racionalista quando levado às suas últimas consequências. Os sofistas já haviam chegado ao "nada"16. Protágoras dizia que "nunca saberíamos a verdade sobre os deuses" e que o homem "é a medida de todas as coisas". Eurípides, influenciado pela sofística, foi acusado pelos religiosos atenienses de ser ateu.

Quais são os efeitos da descoberta do "nada", do "abismo" e a permanência nele? A partir dessa questão, Nietzsche passa da análise do niilismo entendido como processo movido pela vontade de verdade para os efeitos do niilismo como fenômeno psicológico, e passa a tratar do

\footnotetext{
${ }^{16}$ Apesar de terem chegado ao nada, para Nietzsche os sofistas não fizeram uma acusação contra a vida e nisto eles teriam permanecido "helenos", enquanto Sócrates e Platão teriam sido uma reação contra a sofística e contra toda a tradição helênica: "A cultura grega dos sofistas havia medrado a partir de todos os instintos gregos: pertence à cultura do tempo de Péricles, de modo tão necessário como Platão não pertence a ela: tem seus precursores em Heráclito e em Demócrito, nos tipos científicos da filosofia antiga; tem a sua expressão na alta cultura de Tucídides, por exemplo - e afinal, ela teve razão: cada progresso do conhecimento epistemológico e moral restituiu os sofistas... (...) Os sofistas não são nada mais do que realistas: formulam todos os valores e práticas usuais para hierarquização dos valores, - têm a coragem, própria a todos os espíritos fortes, de saber de sua imoralidade..." (NIETZSCHE, 1906, aforismo 428 e 429, p. 239-230)
} 
niilismo passivo, o niilismo ativo e o niilismo perfeito. Mas não é de modo algum nosso objetivo neste momento, e nem no restante deste trabalho, apresentar uma visão do conjunto da filosofia de Nietzsche, e nem mesmo sobre o problema do niilismo, mas apenas tentar elucidar aquilo pode nos ajudar a compreender o significado do trágico em seu pensamento. Nesse sentido, precisamos saber mais sobre porque a posição socrática representou uma hybris para Nietzsche. Para tanto, precisamos nos distanciar da terceira interpretação equivocada sobre a obra de Nietzsche, aquela que vê na crítica de Nietzsche à "tirania da razão" socrática uma defesa da hybris dionisíaca, leitura que transforma Nietzsche num libertário individualista. Sobre este ponto, diz Moura:

“Guardemo-nos, antes de tudo, dos lugares comuns jornalísticos. Sócrates é censurado por promover a razão como tirano em face dos demais instintos. Mas será que Nietzsche estaria insinuando, como cura para a doença socrática, que nos filiemos ao partido oposto, e façamos a apologia das paixões e dos instintos contra a razão, o elogio do corpo contra o espírito? Agora, a palavra de ordem de Nietzsche seria mais ou menos assim: façamos das paixões o tirano da razão - e com tal terapia daremos adeus à 'decadência'. Mas isso seria desconhecer inteiramente o pensamento de Nietzsche, significaria transformá-lo em ideólogo parisiense e opor, ao platonismo, uma caricatura de Cálicles. Não. Não se subverte o platonismo apenas trocando os sinais, torcendo pela 'paixão' contra a 'razão', como se estivéssemos diante de uma pelada entre rivais. Razão e paixão não são adversárias - e já é conceder em demasia ao platonismo encará-las sob o prisma da mútua exclusão. Paremos com a mania de transformar Nietzsche em precursor de Wilhelm Reich - esse platônico a mais da história do pensamento" (MOURA, 2005, p. 222).

Para Nietzsche, o problema não é a razão, é a razão como tirano. A solução não está no partido oposto, na apologia das paixões e dos instintos sem medida. Há muitas demonstrações disso na obra de Nietzsche. No Crepúsculo dos Ídolos, Nietzsche afirma que o remédio oferecido pelo cristianismo foi ainda mais radical que o de Sócrates em sua condenação aos instintos e à vida, pois o cristianismo não era capaz de querer a sublimação ou espiritualização dos instintos e paixões, mas queria a sua extirpação: 
"Por outro lado, é preciso confessar com alguma equidade que, sobre o solo de crescimento do Cristianismo, o conceito de 'Espiritualização da paixão' não podia ser concebido de forma alguma. Como é de fato reconhecido, a igreja primitiva lutou contra os 'Inteligentes' em favor dos 'Pobres de espírito': como seria possível esperar dela uma guerra inteligente contra a paixão? A igreja combate o sofrimento através da extirpação em todos os sentidos: sua prática, seu 'tratamento' é o da castração. Ela nunca pergunta: 'como se espiritualiza, se embeleza, se diviniza um desejo?' Em todos os tempos, ela pôs a ênfase da disciplina na supressão (da sensibilidade, do orgulho, do desejo de domínio, de posse e de vingança). Mas atacar os sofrimentos na raiz é o mesmo que atacar a vida na raiz: a práxis da igreja é inimiga da vida...” (NIETZSCHE, 1888, p. 34) Grifos nossos.

Portanto, para Nietzsche, a Igreja não fez uma "guerra inteligente" contra as paixões, porque pretendeu extirpar os instintos e paixões em vez de “espiritualizar", “embelezar" ou “divinizar" os instintos. Ocorre que os instintos, desejos e paixões não podem ser eliminados, e, não podendo ser canalizados para fora, eles se voltam para dentro, contra o próprio indivíduo, dando origem à "má consciência”, como diz Nietzsche na Genealogia da moral:

"Vejo a má consciência como a profunda doença que o homem teve de contrair sob pressão da mais radical das mudanças que viveu - a mudança que sobreveio quando ele se viu definitivamente encerrado no âmbito da sociedade e da paz (...) Todos os instintos que não se descarregam para fora voltam-se para dentro - isto é o que chamo de interiorização do homem: é assim que no homem cresce o que depois se denomina sua 'alma'. Todo mundo interior, originalmente delgado, como que entre duas membranas, foi se expandindo e estendendo, adquirindo profundidade, largura e altura, na medida em que o homem foi inibido em sua descarga para fora. Aqueles terríveis bastiões com que a organização do Estado se protegia dos velhos instintos de liberdade - os castigos, sobretudo, estão entre esses bastiões - fizeram com que todos aqueles instintos do homem selvagem, livre e errante se voltassem para trás, contra o homem mesmo. A hostilidade, a crueldade, o prazer na perseguição, no assalto, na mudança, na destruição - tudo isso se voltando contra os possuidores de tais instintos: esta é a origem da má consciência” (Nietzsche, 1887, II, 16, p. 73)

O remédio "não inteligente" oferecido pelo cristianismo aprofundou a doença $a^{17}$. Para

\footnotetext{
${ }^{17}$ Como é conhecido, o tema dos impulsos que não podem ser descarregados e se voltam contra o indivíduo será desenvolvido por Freud. Souza escreve que em 1908, em uma reunião da Sociedade Psicanalítica de Viena na casa de Freud, o tema proposto para discussão foi o livro Ecce Homo, de Nietzsche. Freud disse que "ninguém havia alcançado, e dificilmente tornaria a alcançar, o grau de introspecção alcançado por Nietzsche" e que evitava estudar Nietzsche para "preservar a independência de espírito" e "devido à riqueza de ideias daquelas obras" que o impediriam de "ler mais que metade de uma página". Para Freud, haveria muita semelhança entre as investigações
} 
Nietzsche, não se trata de eliminar esses instintos, mas de, em primeiro lugar, reconhecer que eles existem em nós, mesmo os mais terríveis, e em seguida pensar em produzir uma hierarquia de instintos, um equilíbrio tenso de instintos, mais favorável à vida. Acreditamos que a abordagem de Moura ajuda bastante a compreensão do problema quando enfatiza os conceitos de "cultura" e "civilização" na obra de Nietzsche. Nessa chave, a hierarquia/equilíbrio entre instintos é produzida pela Cultura, enquanto a Civilização é entendida por Nietzsche como uma $h_{y b r i s^{18}}$ : a tirania da razão, tirania do apolíneo sobre o dionisíaco. Para Moura, o que Nietzsche chama de "cultura" é uma estilização da natureza, o "contrário, portanto, do laisser-aller" (MOURA, 2005, p. 233). Moura encontra nas análises de Nietzsche sobre a disputa no mundo homérico a chave para compreender a noção de "cultura" de Nietzsche.

No texto A disputa em Homero, de 1872, Nietzsche afirma que o mundo pré-homérico era um mundo cruel de guerras constantes e desejo de aniquilamento, era o mundo dominado pelos "filhos da noite", mundo da "disputa funesta" (na linguagem de Hesíodo em Os trabalhos e os dias, citado por Nietzsche). A partir do período homérico teria havido uma "espiritualização" destes impulsos agressivos, e mesmo que a disputa não tenha sido extirpada, recebeu medida. De acordo com o espírito do agonismo, todas as instituições principais dos gregos estariam organizadas em torno da disputa. Nietzsche observou que, para os gregos, "todo talento deve desdobrar-se lutando" (NIETZSCHE, 1872a, p. 70). A disputa permitiria que o talento aparecesse, que a virtude fosse testada, que a vida se desenvolvesse. Consideravam os gregos que, com a eliminação da disputa, a própria vitalidade se esvairia, as virtudes se enfraqueceriam

do filósofo e as da psicanálise. (Souza, P. C. Citado no Posfácio de NIETZSCHE, 1908, p. 123)

${ }^{18} \mathrm{Na}$ terceira dissertação da Genealogia da Moral, Nietzsche novamente critica a "hybris" dos modernos: "Ainda que medido com o metro dos antigos gregos, todo o nosso ser moderno, enquanto não é fraqueza, mas poder e consciência de poder apresenta-se como pura híbris e impiedade (...) Híbris é hoje nossa atitude para com a natureza, nossa violentação da natureza com ajuda das máquinas e da tão irrefletida inventividade dos engenheiros e técnicos; híbris é nossa atitude para com Deus, quero dizer, para com uma presumível aranha de propósito e moralidade por trás da grande tela e teia da causalidade - podemos dizer, como Carlos I, o Temerário, em luta com Luís XI: je combats l'universalle araignée [eu combato a aranha universal]; híbris é nossa atitude para com nós mesmos, pois fazemos conosco experimentos que não nos permitiríamos fazer com nenhum animal, e alegres e curiosos vivisseccionamos nossa alma" (NIETZSCHE, 1887, III, 9, p.102-3) 
e abriria-se o caminho para a hybris (desmedida/excesso). Para tanto, os gregos promoviam espaços para a disputa em diversas esferas: competições esportivas, competições artísticas de diversos tipos, disputas em forma de diálogo no centro das peças teatrais, disputas políticas na Ágora, onde a palavra era um instrumento importante da disputa que faria emergir líderes talentosos para a pátria.

Para Nietzsche, o egoísmo não é um "mal em si". Tampouco um "bem em si". Ele é, simplesmente. O egoísmo não é único impulso humano, não é a única força, pois também existem outras forças, como afetos e impulsos gregários. Aquilo que Nietzsche por vezes chama de egoísmo também não deve ser reduzido apenas à sua forma estreita de interesse, de "proveito inteligente". Os homens não se movem apenas pelo auto-interesse, para Nietzsche, "só um inglês consegue acreditar nisso"19. Entretanto, o egoísmo em sentido amplo, não podendo ser extirpado, poderia, contudo, ser canalizado, espiritualizado, embelezado. Os gregos teriam feito isso, segundo Nietzsche:

"Para os antigos, entretanto, o objetivo da educação 'agônica' era o bem do todo, da sociedade citadina. Assim, cada ateniense devia desenvolver-se até o ponto em que isto constituísse o máximo de benefício para Atenas, trazendo o mínimo de dano (...) Desde a infância, cada grego percebia em si o desejo ardente de, na competição entre cidades, ser um instrumento para a consagração de sua cidade: isso acendia o seu egoísmo, mas, ao mesmo tempo, o refreava e limitava. Por isso, os indivíduos da antiguidade eram mais livres, porque seus objetivos eram mais próximos e alcançáveis. O homem moderno, ao contrário, tem a infinidade cruzando o seu caminho em toda parte, como o veloz Aquiles na parábola do eleata Zenão: a infinidade o obstrui, ele nunca alcança a tartaruga". (NIETZSCHE, 1872a, p. 73) Grifos nossos.

A educação agônica promovia um direcionamento do egoísmo que ligava o cidadão em busca de glória com o bem comum, trazendo o "máximo benefício para Atenas". A própria

\footnotetext{
${ }^{19}$ Diz Nietzsche no aforismo 930 da Vontade de Poder: "Quanta vantagem o homem sacrifica, quão pouco 'egoísta' ele é! Todos os seus afetos e paixões querem ter o seu direito - e como o afeto encontra-se distante do proveito inteligente do egoísmo! Não se quer a sua 'felicidade'; precisa-se ser inglês para poder acreditar que o homem busque sempre vantagem. Nossos desejos querem violar as coisas em uma longa paixão, - sua força concentrada procura resistências" (NIETZSCHE, 1906, p. 460)
} 
disputa também forneceria medida ao egoísmo. Nesse sentido, Nietzsche interpreta a instituição do ostracismo como um instituto destinado a garantir a manutenção da disputa política. Quando um cidadão adquiria proeminência exagerada de modo a adquirir poder suficiente para obter a tirania e encerrar a disputa, eliminando os adversários, havia a possibilidade de condená-lo ao ostracismo. Nietzsche cita o exemplo dos efésios que, ao banirem Hermodoro, teriam dito: "Entre nós ninguém deve ser o melhor; se alguém for, todavia, então que seja em outra parte e na companhia de outros", ao que Nietzsche comenta:

"É este o germe da noção helênica de disputa: ela detesta o domínio de um só e teme seus perigos, ela cobiça, como proteção contra o gênio - um segundo gênio." (NIETZSCHE, 1872a, p. 72)

Aparece aí, na cultura grega trágica, a ideia de que a melhor medida para uma vontade é outra vontade igualmente forte e contrária, um "segundo gênio" como proteção contra o gênio. Esta avaliação positiva do conflito e da maneira de fornecer-lhe medida será típica de um olhar trágico e realista sobre a política, presente em Maquiavel e Nietzsche, como notou Gambino:

“Quando Nietzsche sugere que ele deve ser lido na tradição do realismo de Tucídides e Maquiavel, ele faz isso não porque quer impor a identidade através da dominação, mas porque ele entende que o total domínio sobre seus oponentes é inconsistente com a ideia agônica. O realismo político é uma doutrina das limitações trágicas e requer dos atores políticos força suficiente para lidar com as contingências da existência temporal" (GAMBINO, 1996, p. 443).

“O total domínio sobre seus oponentes é inconsistente com a ideia agônica”. Tanto o governo tirânico de um só na polis, quanto a tirania de um só impulso ou força (a razão) no indivíduo são inconsistentes com a ideia agônica. Quer dizer, o agonismo pressupõe uma forma de dar medida que está mais no paradigma do jogo do que no da dominação total ou da "disputa funesta”. Nietzsche não faz uma defesa nem de uma hybris apolínea, nem de uma hybris do dionisismo irrestrito, uma apologia da liberação de todos os instintos sem medida. O que há é uma diferente maneira organizar as forças. Contra a estratégia de Sócrates e do cristianismo, que 
apontariam no sentido de uma dominação tirânica de uma força sobre todas as outras - o que seria inconsistente com "a ideia agônica", como notou Gambino - Nietzsche pensa em uma estilização dos instintos, uma hierarquia entre eles favorável à vida. Diz Moura:

“A estilização dos instintos vai produzir, no interior de cada indivíduo, aquilo que ocorria na vida da pólis helênica: sempre o conflito, sempre a hierarquia, mas nunca a dominação absoluta, que põe fim à disputa. A decadência de Alexandre prefigura a decadência de Sócrates: seja com a supremacia absoluta de um só homem na cidade, seja com a tirania da razão sobre os instintos, há o fim da resistência, o fim da disputa, o término da superação de si, a 'decadência"'. (MOURA, 2005, p. 234)

O fim da disputa representaria o fim da resistência, mas a resistência permite um aumento da força, uma "superação de si" ${ }^{20}$. Nietzsche acredita que os gregos haviam percebido isto, ao considerarem que a disputa seria boa por fornecer uma medida, um limite que manteria uma espécie de tensão produtiva ${ }^{21}$. Uma cidade saudável, assim como um indivíduo saudável, tem que "ser rico em oposições" para ser fecundo. ${ }^{22}$ A cultura de um povo saudável, fornece estilo aos instintos, estilo que cria uma determinada hierarquia entre os instintos, um determinado equilíbrio, uma tensão produtiva. Assim como o cultivo de si (o autodomínio), que é estimado no discurso nietzscheano, também é uma estilização. Para continuar a análise do que significa "estilização" dos instintos, retomemos o texto a que Gambino se refere, em que Nietzsche diz que deve ser lido na tradição do realismo de Tucídides e Maquiavel:

20 "A vontade de poder só pode externar-se em resistências; ela procura, portanto, por aquilo que lhe resiste" (NIETZSCHE, 1906, aforismo 656, p.331)

${ }^{21}$ Nietzsche entende que o cristianismo foi radical, uma hybris, porque em vez de espiritualizar os instintos, procurou extirpá-los, condená-los, como no caso do amor e da "hostilidade". Em Moral como Contra-natureza, aforismo 3, do Crepúsculo dos Ídolos diz Nietzsche: "A espiritualização da sensualidade é chamada amor: representa um grande triunfo sobre o cristianismo. Outro triunfo é a nossa espiritualização da hostilidade. Ela consiste num profundo reconhecimento do valor de se ter inimigos: em suma, significa agir e pensar de modo oposto ao que outrora era a regra. A Igreja sempre desejou a destruição de seus inimigos; nós, imoralistas e anticristãos, encontramos nossa vantagem nisto: que a Igreja existe. No âmbito da política a hostilidade também se tornou mais espiritualizada - muito mais sensível, muito mais pensativa, muito mais ponderada. Quase todo partido compreende que é de interesse à sua própria autopreservação que seus opositores não percam toda a força; o mesmo vale para políticos poderosos (NIETZSCHE, 1888, p. 35)

${ }^{22}$ No último Nietzsche, em Crepúsculo dos Ídolos, de 1888, essa ideia de tensão produtiva (entre as diferentes forças da cidade, e entre as diferentes forças no interior do indivíduo) permanece: "É preciso ser rico em oposições, é só pagando esse preço que se é fecundo; só se permanece jovem sob a pressuposição de que a alma não se espreguiça, não anseia pela paz... Nada nos parece mais estranho do que o que era desejável outrora, o que era desejável para o cristão: a 'paz de alma"' (NIETZSCHE, 1888, p. 35) 
"Meu descanso, minha predileção, minha cura de todo platonismo sempre foi Tucídides. Tucídides e, talvez, O Príncipe de Maquiavel são os mais próximos a mim mesmo, pela incondicional vontade de não se iludir e enxergar a razão na realidade - não na 'razão', e menos ainda na 'moral'... Desse lamentável embelezamento e idealização dos gregos, que o jovem de 'formação clássica' leva para a vida como prêmio por seu treino ginasial, disso nada cura tão radicalmente como Tucídides. É preciso revirá-lo linha por linha e ler seus pensamentos ocultos tanto quanto suas palavras: há poucos pensadores tão pródigos em pensamentos ocultos. Nele acha expressão consumada a cultura dos sofistas, quero dizer, a cultura dos realistas: esse inestimável movimento em meio ao embuste moral e ideal das escolas socráticas, que então irrompia em toda parte. A filosofia grega como a décadence do instinto grego; Tucídides como a grande suma, a revelação última da forte, austera, dura factualidade que havia no instinto dos velhos helenos. A coragem ante a realidade é o que distingue, afinal, naturezas como a de Tucídides e Platão: Platão é um covarde perante a realidade - portanto, refugia-se no ideal; Tucídides tem a si sob controle; portanto, mantém também as coisas sob controle...” (NIETZSCHE, 1888, p. 103)

Por que coragem e covardia entram nesse discurso de Nietzsche? Porque a covardia ou cansaço diante do fluxo do devir estava por trás da tentativa de abolir a todo custo o sofrimento, procurando extirpá-lo em suas raízes, o que acabava minando também as fontes de alegria, e levava o sofredor a se refugiar no ideal (o mundo verdadeiro) - a partir do qual se promoveria uma condenação deste mundo e da vida - e à imposição da dominação tirânica de uma força (a razão) sobre todas as outras. Platão opôs ao fluxo do devir o "mundo verdadeiro", quis eliminar a disputa política entre as diferentes "forças" na cidade e era contrário à democracia da época dos trágicos, e tentou, sem sucesso, testar suas ideias políticas com a ajuda do tirano de Siracusa. Tucídides e os sofistas, que "mantinham a si mesmos sob controle", eram mais capazes de suportar e não condenavam a disputa, e, entre os sofistas estavam os maiores defensores da democracia em Atenas. O remédio dos "cansados" era mais radical, mas, para Nietzsche, era um remédio que aprofundava a doença.

A coragem diante da realidade, por sua vez, não significa um elogio à temeridade, mas a recusa a procurar abolir o sofrimento a todo custo, como no caso de um sujeito que após grave 
desilusão amorosa decide "não amar mais ninguém", para não sofrer novamente, mas, ao fazer isso, está abandonando também uma grande fonte de alegria. A “coragem trágica” significa aceitar o fluxo, não estar disposto a tudo para eliminar o sofrimento, aceitá-lo como parte integrante da vida e abrir-se assim à alegria do devir. Essa aceitação do fluxo e esse dizer sim à vida inteira, com suas alegrias e sofrimentos, constitui o dionisismo do artista trágico:

“O artista trágico não é nenhum pessimista. Ele diz sim a tudo que é digno de questão e passível mesmo de produzir terror, ele é dionisíaco...” (NIETZSCHE, 1888, p. 30)

Aqui, aparentemente recaímos no dionisismo irrestrito. Entretanto, para suportar o fluxo é preciso exercitar o autodomínio - é preciso ter certa dureza - que resulta de uma estratégia apolínea, um querer dar forma, uma estilização. Diz Nietzsche no aforismo 290 de Gaia Ciência:

“Uma coisa é necessária - 'Dar estilo a seu caráter - uma arte grande e rara! É praticada por quem avista tudo o que sua natureza tem de forças e fraquezas e o ajusta a um plano artístico, até que cada uma delas aparece como arte e razão, e também a fraqueza delicia o olhar. Aqui foi acrescentada uma grande massa de segunda natureza, ali foi removido um bocado de primeira natureza: - ambas as vezes com demorado exercício e cotidiano lavor. Aqui o feio que não podia ser retirado é escondido, ali é reinterpretado como sublime (...) Por fim, quando a obra está consumada, torna-se evidente como foi a coação de um só gosto que predominou e deu forma, nas coisas pequenas como nas grandes: se o gosto era bom ou ruim não é algo tão importante como se pensa - basta que tenha sido um só gosto! - Serão as naturezas fortes, sequiosas de domínio, que fruirão sua melhor alegria numa tal coação, num tal constrangimento e consumação debaixo de sua própria lei; a paixão do seu veemente querer se alivia ao contemplar toda natureza estilizada, toda natureza vencida e serviçal; mesmo quando tem palácios a construir e jardins a desenhar, resistem a dar livre curso à natureza. - Inversamente, são os caracteres fracos, nada senhores de si, que odeiam o constrangimento do estilo: eles sentem que, se lhes fosse imposta essa maldita coação, debaixo dela viriam a ser vulgares" (Gaia Ciência, aforismo 290, p. 195-6)

Para Nietzsche, as naturezas fortes se aliviam ao contemplar a natureza estilizada, enquanto as fracas "odeiam o constrangimento do estilo". Todo estilo envolve uma coação, cortes artísticos sobre a matéria, imposição de uma hierarquia. Não é um laissez-aller. Vejamos um trecho da Vontade de Poder que em nossa opinião ajuda a afastar o erro de considerar 
Nietzsche um defensor da desmedida e do individualismo libertário. Uma das fontes dessa leitura equivocada foi o uso frequente do termo "domesticação" em suas obras, uso que, lido sem cuidado, nos levaria a entender Nietzsche como contrário a toda "domesticação" porque ela seria sinal de enfraquecimento. O próprio Nietzsche procura esclarecer o mal-entendido:

“O que desejo com todas as forças tornar claro: a) que não há pior equívoco do que confundir domesticação com enfraquecimento: o que realmente se fez... / A domesticação é, tal como a compreendo, um meio de imensa acumulação de forças da humanidade, de modo que as gerações possam continuar a construir sobre o trabalho de seus antepassados - não apenas exteriormente, mas internamente, brotando organicamente deles naquilo que é mais vigoroso... b) há um perigo extraordinário quando se acredita que a humanidade como um todo cresça continuamente e se torne mais forte, quando os indivíduos tornam-se frouxos, iguais, medíocres... Humanidade é uma abstração: o alvo da domesticação, mesmo no caso mais individual e singular, não pode ser outro senão o homem mais forte (o homem não domesticado é fraco, dissipador, inconstante...)" (NIETZSCHE, 1906, aforismo 398, p. 212)

Para Nietzsche, a domesticação é um "meio de imensa acumulação de forças da humanidade", a questão é que tipo de domesticação é mais favorável à vida, se é uma domesticação que visa produzir indivíduos fortes e alegres, ou fracos e niilistas. Mas alguma domesticação é necessária para o "acúmulo de forças". Para Nietzsche, o homem não domesticado é "fraco, dissipador, inconstante"23. Na Gaia Ciência, aforismo 124, há uma reflexão sobre a ausência de limites, a infinitude dos tempos modernos:

“No horizonte do infinito - Deixamos a terra firme e embarcamos! Queimamos a ponte - mais ainda, cortamos todo laço com a terra que ficou para trás! Agora tenha cautela, pequeno barco! Junto a você está o oceano, é verdade que ele nem sempre ruge, e às vezes se estende como seda e ouro e devaneio de bondade. Mas virão

\footnotetext{
${ }^{23}$ Hegel também tinha chegado ao mesmo diagnóstico crítico da "liberdade abstrata" do "laissez-aller", vista por ele como produtora de dissolução. Hegel promove a crítica da Möralitat (moralidade ao estilo de Kant) e a entende como um momento do mais concreto movimento da Sittlichkheit (Eticidade). Os problemas derivados da "indeterminação" da liberdade abstrata são analisados por Axel Honneth em seu texto "Patologias da Liberdade Individual - O diagnóstico hegeliano de época e do presente". Em: Novos Estudos, no 66, 2003. Honneth procura mostrar que a desmedida da liberdade individual leva ao que Hegel chamou de "Sofrimento por indeterminação" e que as investigações psicológicas atuais confirmam esse diagnóstico hegeliano, ao apontar o crescimento dos sintomas de depressão, que substituem cada vez mais os sintomas da neurose. $\mathrm{O}$ crescente sucesso da indústria dos antidepressivos seria um sintoma do sofrimento por indeterminação.
} 
momentos em que você perceberá que ele é infinito e que não há coisa mais terrível que a infinitude. Oh, pobre pássaro que se sentiu livre e agora se bate nas paredes desta gaiola! Ai de você, se for acometido de saudade da terra, como se lá tivesse havido mais liberdade - e já não existe mais 'terra'!” (NIETZSCHE, 1882, p. 147)

Nós, homens modernos, abandonamos a terra, a cultura, o cultivo, e "embarcamos", nunca houve tanto "mar aberto" ${ }^{24}$, o que significa uma nova aurora de possibilidades, entretanto, "não há coisa mais terrível que a infinitude", pois significa ausência de limites, quer dizer, ausência de apoios a partir dos quais se erguem as identidades. Apoios que são sempre arbitrários - buscar a razão nos apoios/mitos é dar início ao niilismo, à destruição dos mitos ${ }^{25}$, é um modo de enfraquecimento pela via da hybris "socrática". Por outro lado, o dionisismo irrestrito aponta para a dissolução de todos os limites, isso também significa dissolução das identidades, é a via do enfraquecimento por hybris dionisíaca. A manutenção das identidades requer o elemento apolíneo, a coação artística. O exagero em uma forma de coação, entretanto, significa fechamento em relação às possibilidades criativas da vida. Para Nietzsche, a cultura trágica admitia a necessidade da coação, mas mantinha um equilíbrio entre o apolíneo e o dionisíaco, a

\footnotetext{
${ }^{24} \mathrm{O}$ "mar aberto" é recebido com entusiasmo pelos "espíritos livres", entretanto, isso não significa que não existam custos em escolher o mar aberto, e nem que todos sejam capazes de serem espíritos livres. Para um racionalista é difícil compreender essa posição "ambígua" de Nietzsche, porque tende a acreditar que o que é possível para um indivíduo é possível para todos, que tudo tem solução racional, que um bem só pode trazer um bem, não concebem um bem que traga também um mal, que é possível fazer uma escolha que não tenha custos, ou ainda "que a humanidade só se coloca problemas que pode resolver", como disse Marx. Entretanto, Nietzsche, ao mesmo tempo em que aponta o lado terrível da infinitude, também saúda o "mar aberto". Em Gaia Ciência, aforismo 343: "De fato, nós, filósofos e 'espíritos livres', ante a notícia de que 'o velho deus morreu' nos sentimos como que iluminados por uma nova aurora; nosso coração transborda de gratidão, espanto, pressentimento, expectativa - enfim o horizonte nos aparece novamente livre, embora não esteja limpo, enfim nossos barcos podem novamente zarpar ao encontro de todo perigo, novamente é permitida toda ousadia de quem busca o conhecimento, o mar, o nosso mar, está novamente aberto, e provavelmente nunca houve tanto 'mar aberto"' (NIETZSCHE, 1882, p. 234)

${ }^{25}$ Para Nietzsche, toda educação moral teria a função de "dar segurança aos instintos", mas quando o dialético Sócrates começa a buscar razões, a procurar por trás dos costumes uma verdade, começa uma "desnaturalização" da moral que teria levado a uma desordem dos instintos desfavorável à vida (NIETZSCHE, 1906, 430, p. 231-2). Hannah Arendt também aponta os limites da filosofia na cidade e a inevitabilidade dos preconceitos no mundo social (na caverna), isto a coloca fora da posição iluminista: "Pois nenhum homem pode viver sem preconceitos, não apenas porque não teria inteligência ou conhecimento suficiente para julgar de novo tudo que exigisse um juízo seu no decorrer de sua vida, mas sim porque tal falta de preconceito requereria um estado de alerta sobre-humano. Por isso, a política tem de lidar sempre e em toda parte com o conhecimento e com a dispersão de preconceitos, o que não significa tratar-se, no caso de uma educação para a perda de preconceitos, nem que aqueles que se esforcem para fazer tal esclarecimento sejam livres de preconceitos. (...) Por conseguinte, o preconceito desempenha um grande papel na coisa social pura; na verdade, não existe nenhuma estrutura social que não se baseie mais ou menos em preconceitos, através dos quais certos homens são permitidos e outros excluídos. Quanto mais livre de preconceitos é um homem, menos apto será para a coisa social pura”. (ARENDT, 2007, pp. 29-30).
} 
civilização moderna, por sua vez, apresenta-se como uma época de liberdade muito maior, de ausência de limites, ausência de coação. Entretanto, para Nietzsche, a civilização moderna esconde uma coação ainda maior, que procura não dar forma nem castigar, mas neutralizar, quer dizer, tornar os cidadãos inofensivos. No aforismo 201, de Além do Bem e do Mal, diz Nietzsche:

"Na história da sociedade há um ponto de amolecimento e enlanguescimento doentio, no qual ela mesma, de modo inclusive sério e honesto, toma o partido de quem a prejudica, de seu infrator. Castigar lhe parece de algum modo injusto - certamente a ideia de 'castigo' e 'dever castigar' lhe dói, lhe dá medo. 'Não basta torná-lo inofensivo? Para que castigar? Castigar é terrível!' - com essa pergunta a moral de rebanho, a moral do temor, tira a sua última consequência. Supondo que se pudesse eliminar o perigo, o motivo do temor, seria eliminada também essa moral: ela não seria mais necessária, ela não mais se tomaria por necessária! - Quem examinar a consciência do europeu de hoje haverá de extrair, de entre mil dobras e recessos morais, sempre o mesmo imperativo, o imperativo do temor do rebanho: 'queremos que algum dia não haja mais nada a temer!'. Algum dia - em toda a Europa, a via e a vontade que conduzem a ele se chamam agora 'progresso"'. (NIETZSCHE, 1886, p. 88)

O imperativo do temor de rebanho - "queremos que um dia não haja mais nada a temer"26 - move as medidas da civilização para tornar os cidadãos inofensivos ${ }^{27}$, e isto é chamado de progresso, mas Nietzsche entende nisso uma hybris que leva à perda de liberdade, entendida

\footnotetext{
${ }^{26}$ Moura comenta sobre este imperativo: "Mas o que é que se supõe para que não haja mais nada a temer na convivência? Nada mais, nada menos que a vida comunitária possa ser por princípio não conflituosa, que se possa exorcizar dela todo e qualquer polemos. (...) A paz certamente reinará no estábulo se as vontades estiverem paralisadas e se o homem for por princípio um 'esgotado"' (MOURA, 2005, p. 95).

${ }^{27}$ É notável a crítica à "neutralização" em diversas utopias negativas que foram adaptadas ao cinema. No filme Laranja Mecânica, de Stanley Kubrick, a sociedade aprova o uso de uma nova tecnologia para combater o crime, uma espécie de lobotomia que será testada no jovem delinquente Alex. Em vez de castigar, o "tratamento Ludovico", instala um dispositivo no cérebro que faz com que os impulsos agressivos de Alex se voltem contra ele mesmo sempre que aparecem. A invenção é recebida com entusiasmo na opinião pública que quer "não ter mais nada a temer". Houve críticas de pessoas ligadas aos direitos humanos, representadas no filme por um professor, este, entretanto, muda radicalmente de opinião depois que sua esposa é violentada na sua frente pela gangue de Alex. Castigar, entretanto, seria muito duro, o método Ludovico é mais "humano". O filme Fahrenheit 451, de Truffaut, trata de uma sociedade futura em que os livros são proibidos porque despertariam sentimentos perigosos e opiniões próprias, consideradas anti-sociais e hedonistas. Os "bombeiros" no filme tem a função de prender as pessoas que estão em uma resistência clandestina e queimar os livros encontrados. A sociedade agradece no filme, pois as medidas visavam "nosso próprio bem", quer dizer, atendiam ao imperativo do "rebanho" de "não ter mais nada a temer". Esquema parecido encontramos em Alphaville, de Godard, que apresenta uma sociedade futurista controlada pelo supercomputador, Alpha 60, que aboliu os sentimentos, também em nome da paz e do bem da sociedade. Estrutura semelhante encontramos no filme mais recente, Minority Report, cujo enredo se passa em Washington, no ano de 2054, quando a "divisão de pré-crime" conseguiu produzir um dispositivo que pune o criminoso antes que o crime seja cometido, para "o bem da sociedade" que "não terá mais nada a temer". Já em $A s$ Bacantes, de Eurípides, o rei Penteu, representante da hybris da razão, hybris apolínea, é trucidado pelas bacantes tresloucadas.
} 
como neutralização da vida (retornaremos a este ponto adiante). Não se trata, portanto, da ideia de liberdade à moda racionalista, tal como aparece na noção de livre-arbítrio ou em Kant. Para Nietzsche, a noção de livre-arbítrio pressupõe que exista algo fora da totalidade, fora da necessidade, e que tenha capacidade de se impor sobre a necessidade, este "fora" pode ser Deus, Alma, Razão. Como, para Nietzsche - e, segundo ele, para todos os europeus modernos que acompanharam a "morte do velho Deus" -, não existe nada fora da totalidade, a ideia de livrearbítrio parte de um pressuposto falso. Para Nietzsche, a noção de livre-arbítrio teve sua primeira formação mais acabada no cristianismo, e seu último grande desenvolvimento em Kant, com seu “imperativo categórico" e seu conceito de autonomia. Entretanto, segundo Nietzsche, a ideia já havia "talvez" sido esboçada por Platão. Se Nietzsche rejeita a doutrina do livre-arbítrio qual é a sua doutrina sobre a liberdade? Prossegue Nietzsche:

"Qual pode ser a nossa única doutrina? - Que ninguém dá ao homem suas propriedades; nem Deus, nem a sociedade, nem seus pais e ancestrais, nem ele mesmo (o contra-senso da representação, aqui por fim recusada, é ensinado por Kant, e talvez até mesmo por Platão, como "liberdade inteligível"). Ninguém é responsável em geral por ele existir, por ele ser constituído de tal ou tal modo, por ele se encontrar sob estas circunstâncias, nesta ambiência. A fatalidade de sua existência não pode ser separada da fatalidade de tudo o que foi e de tudo o que será. O homem não é consequência de uma intenção própria, de uma vontade, de uma finalidade. Com ele não é feita uma tentativa de alcançar um 'ideal de homem' ou um 'ideal de felicidade' ou um 'ideal de moralidade' (...) É-se necessariamente, se é um pedaço de fatalidade, se pertence ao todo, se está no todo. Não há nada que pudesse julgar, medir, comparar, condenar nosso ser, pois isso significaria julgar, medir, comparar, condenar o todo... Mas não há nada fora do todo! Que ninguém mais seja responsável, que o modo de ser não possa ser reconduzido a uma causa prima, que o mundo não seja uma unidade nem enquanto mundo sensível, nem enquanto 'espírito': só isso é a grande libertação. - Com isso a inocência do vir-a-ser é restabelecida...” (NIETZSCHE, 1888, P. 50)

Portanto, a doutrina do livre-arbítrio, base da noção moderna e liberal de liberdade ${ }^{28}$, para

\footnotetext{
${ }^{28}$ Sandel entende que o núcleo do liberalismo é formado pela ideia de que existe um "eu racional" que "escolhe livremente entre os fins dados socialmente" e que, em uma sociedade justa, o Estado não deve promover nenhuma concepção de bem em particular, mas liberar os cidadãos para perseguir seus próprios fins, de acordo com uma liberdade similar para todos. Quer dizer, o liberalismo pressupõe um eu esvaziado de todo conteúdo, seja ele pulsional ou derivado dos "fins dados socialmente", é o que ele chamou de "unencumbered self" (SANDEL, 1992)
} 
Nietzsche, parte de um pressuposto falso, o de que exista um "fora", um eu racional exterior à necessidade e que escolhe livremente entre os impulsos (inclusive supostamente livre em relação aos impulsos gregários, os quais recebem conteúdo dos costumes, da cultura ou da eticidade, como preferia Hegel). Para Nietzsche, o que nós chamamos de "eu" é o resultado de uma determinada "economia pulsional” (para usar uma linguagem posterior à Nietzsche). Quando "nós" acreditamos dominar um impulso, quando nos queixamos de um impulso impetuoso, na verdade, para Nietzsche, é um "impulso que se queixa de outro" 29 . Mas, para Nietzsche, a doutrina do "eu racional" que escolhe livremente não é apenas falsa, ela cumpriu também uma função: tornar os homens culpados. Diz Nietzsche, no Crepúsculo dos Ídolos:

“Os homens foram pensados como 'livres', para que pudessem ser julgados e punidos - para que pudessem ser culpados. Consequentemente, toda ação precisaria ser considerada como desejada, a origem de toda ação como estando situada na consciência.”. (NIETZSCHE, 1888, p. 49).

No lugar da doutrina do livre-arbítrio - da doutrina teológica, teleológica e transcendental - vista como falsa, Nietzsche começa a esboçar um outro conceito de liberdade, uma liberdade "vista de dentro", que nós chamaremos de "gaia liberdade" e que aparecia já em Maquiavel. Essa concepção não pressupõe um "fora" da totalidade a partir do qual se pudesse domar a necessidade e condenar aqueles que não conseguissem "domar a necessidade". A partir da doutrina do livre-arbítrio, um criminoso torna-se um homem muito mau, um pecador, um imoral, um homem que poderia ter agido de forma diferente, mas escolheu ser mau e deve portanto ser punido com rigor. Não há como compreender sua ação má. Para Nietzsche, essa doutrina de liberdade como livre-arbítrio mostraria que "o cristianismo é uma metafísica do carrasco" (NIETZSCHE, 1888, p. 49), que Nietzsche quer abandonar em favor de outra noção de

\footnotetext{
29 “mas querer combater a veemência de um impulso não está em nosso poder, nem a escolha do método, e tampouco o sucesso ou fracasso desse método. Em todo esse processo, claramente, nosso intelecto é antes o instrumento cego de um outro impulso, rival daquele que nos tormenta com sua impetuosidade: seja o impulso por sossego, ou o temor da vergonha e de outras más consequências, ou o amor. Enquanto 'nós' acreditamos nos queixar da impetuosidade de um impulso, é, no fundo, um impulso que se queixa de outro; isto é: a percepção do sofrimento com tal impetuosidade pressupõe que haja um outro impulso tão ou mais impetuoso, e que seja iminente uma luta, na qual nosso intelecto precisa tomar partido". (NIETZSCHE, 1881, aforismo 109, p. 81)
} 
liberdade, inspirada nos trágicos, e, segundo ele, mais adequada para aqueles que acompanharam a "morte do fundamento" e suas consequências, como o fim da teleologia. O pré-teleológico mundo dos trágicos gregos encontra-se aqui com o mundo pós-teleológico dos europeus modernos. Para Nietzsche, a "liberdade de alma" presente nos trágicos gregos não estava conectada à má consciência, não estava de tal modo ligada à culpa. Os deuses não eram mobilizados para intensificar o sentimento de culpa. Diz Nietzsche no livro II, aforismo 23, da Genealogia da Moral:

"Por muito e muito tempo, esses gregos se utilizaram dos seus deuses precisamente para manter afastada a 'má consciência', para poder continuar gozando a liberdade da alma: uso contrário, portanto, ao que o cristianismo fez do seu Deus. Nisso eles foram bem longe, essas crianças magníficas e leoninas. (...) 'como são loucos' é o que pensa, ao observar os malfeitos dos mortais - e 'loucura', 'insensatez', um pouco de 'perturbação na cabeça', tudo isso admitiam de si mesmos até os gregos da era mais forte e mais valente, como motivo de muita coisa ruim e funesta loucura e não pecado! Vocês compreendem?” (NIETZSCHE, 1887, II, 23, p. 83)

"Loucura e não pecado", nessa forma de entender as ações que produziram sofrimento ocorre uma "grande liberação" que desconecta o sofrimento da culpa. Para Nietzsche, o cristianismo conectou, colocou "na mesma balança", a infelicidade e a culpa, os trágicos gregos, por sua vez, tinham os "pés leves" e fizeram diferente. Não é que as tragédias gregas não tratassem de culpa e de infelicidade, mas o faziam, segundo Nietzsche, de forma diferente:

"A culpa de seus heróis trágicos é a pequena pedra na qual tropeçam e, por isso, quebram o braço ou arrancam um olho: a sensibilidade antiga comentava sobre isso: 'Sim, ele deveria ter seguido sua estrada com mais cautela e menos petulância!' Mas apenas ao cristianismo estava reservado dizer: 'Eis uma grave infelicidade, e por trás dela tem de se esconder uma culpa grave, igualmente grave, ainda que não a vejamos claramente!' Se você, infeliz, não percebe isto assim, está endurecido - experimentará coisas ainda piores! - Na Antiguidade ainda havia realmente infelicidade, pura, inocente infelicidade; apenas no cristianismo tudo se torna castigo, punição bem merecida: ele faz sofredora também a imaginação do sofredor, de modo que este, em tudo o que sucede de mau, sente-se moralmente reprovado e reprovável; Pobre humanidade! Os gregos têm uma palavra própria para a indignação com a infelicidade do outro: este afeto era inadmissível entre os povos cristãos e desenvolveu-se pouco, 
e assim eles carecem de nome para esse irmão viril da compaixão" (NIETZSCHE, 1881, aforismo 78, p. 62-3)

A desconexão entre infelicidade e culpa, que Nietzsche quer novamente promover, permite que seja restaurada a "inocência do devir", a que Nietzsche se referiu no trecho antes citado do Crepúsculo dos Ídolos, e isto seria uma "grande liberação". Para Nietzsche, o modo trágico de lidar com o sofrimento, com a infelicidade, é organizado de um modo que não leva nem à má consciência, nem à condenação da vida, nem às medidas de neutralização da vida operadas pela civilização, movidas pelo temor de rebanho ("que um dia não haja nada mais a temer"). O fato de os trágicos não conectarem a infelicidade com uma culpa grave e intencional, de considerarem a queda do herói como fruto de um erro, "uma loucura e não pecado", não significa que eles ou Nietzsche fossem algo como os anti-penalistas modernos, que fossem libertários contrários a qualquer punição. Os trágicos não questionavam a necessidade da punição. O homem vive em sociedade e precisa estabelecer regras, "se deve cuidar das leis como se cuida dos muros da polis", dizia Heráclito. Entretanto, para Nietzsche, não é necessário transformar o criminoso em alguém que além de ter cometido um delito, escolheu o mal, sendo, portanto, duplamente culpado. Sobre a sua ação, seu delito, nós não sabemos o suficiente sobre as circunstâncias, sobre os deuses que o cegaram, sobre a loucura que o dominou, sobre a fatalidade de arranjo de impulsos que constitui o "eu" deste agente ${ }^{31}$. Diante de todo o palavrório ${ }^{30}$ A "palavra própria" grega a que Nietzsche se refere para a indignação com a infelicidade do outro talvez seja
eleos. Para Aristóteles, a tragédia deveria nos despertar eleos e phobos, que são traduzidas normalmente como
compaixão/piedade e medo/temor, entretanto, para Kaufmann, não existe uma palavra simples para traduzir eleos, e
muitas vezes é melhor traduzí-la por simpatia (KAUFMANN, 1968, p. 45), talvez ele estivesse pensando no que
Nietzsche disse sobre o "irmão viril da compaixão". Aristóteles, com a linguagem "machista" de seu tempo, também
havia criticado um gênero "efeminado" de compaixão: "A simples presença de um amigo nos é agradável,
especialmente se estamos na adversidade, e se torna uma salvaguarda contra as aflições, pois um amigo tende a
confortar-nos tanto com sua presença quanto com suas palavras se ele é perspicaz, pois ele conhece o nosso caráter e
as coisas que nos dão prazer ou nos fazem sofrer; mas ver um amigo sofrer com nosso infortúnio nos causa
sofrimento, pois qualquer pessoa evita causar sofrimento aos amigos. É por isto que as pessoas de natureza viril
se abstém de afligir seus amigos e, a não ser que uma pessoa seja excepcionalmente insensível ao sofrimento, ela
não pode tolerar o sofrimento que o seu sofrimento causa aos amigos, e não admite que outras pessoas se lamentem
com ela, porque ela mesma não é propensa a lamentações; as mulheres, porém, e os homens efeminados, apreciam
as pessoas solidárias com suas aflições, e gostam delas como amigas e companheiras na tristeza. Mas obviamente
deve-se imitar em tudo as pessoas melhores." (Aristóteles. Ética a Nicômacos, 1171b, p. 189)
${ }^{31}$ Para Nietzsche nem o próprio agente conhece bem os seus impulsos e motivos, o nosso autoconhecimento seria
muito limitado: "Por mais longe que alguém leve seu autoconhecimento, nada pode ser mais incompleto do que sua
imagem da totalidade dos impulsos que constituem seu ser. Mal conseguirá dar o nome dos mais grosseiros entre
ima 
a respeito das intenções, os trágicos diziam simplesmente: quem comete delito é punido. Nada podemos dizer sobre os motivos que justifique um duplo julgamento. Essa maneira trágica e mais leve de entender o crime e o infortúnio, permitia até mesmo que se compreendesse ou que se sentisse simpatia pelo herói caído, apesar de seus erros.

Mas ainda não sabemos bem o que é liberdade para Nietzsche, sabemos o que ela não é; falta encontrarmos um conceito positivo de liberdade em Nietzsche. Para tanto, precisamos elucidar o que sobra, na visão de Nietzsche, depois que o "velho Deus morreu" - a aranha de propósito na cadeia dos eventos -, precisamos saber o que resta depois da "morte do fundamento", do "mundo verdadeiro", da teleologia. Para Nietzsche, o que resta quando este mundo transcendente cai é o mundo "visto de dentro", e a suposição de Nietzsche - que ele ironicamente diz que é imposta pelo método, que não admite diversas espécies de causalidade e tem de reduzi-las a uma só -, é que o mundo é “vontade de poder”:

“Supondo que nada seja 'dado' como real, exceto nosso mundo de desejos e paixões, e que não possamos descer ou subir a nenhuma outra 'realidade', exceto à realidade de nossos impulsos - pois pensar é apenas a relação desses impulsos entre si (...) Supondo, finalmente, que se conseguisse explicar toda a nossa vida instintiva como a elaboração e ramificação de uma forma básica de vontade - a vontade de poder, como é a minha tese -; supondo que se pudesse reconduzir todas as funções orgânicas a essa vontade de poder, e nela se encontrasse também a solução para o problema da geração e nutrição - é um só problema -, então se obteria o direito de definir toda força atuante, inequivocamente, como vontade de poder. $\mathrm{O}$ mundo visto de dentro, o mundo definido e designado conforme o seu 'caráter inteligível' - seria justamente 'vontade de poder', e nada mais" (NIETZSCHE, 1886, aforismo 36, pp. 39-40)

Não entraremos na polêmica inaugurada por Heidegger, quando defendeu que o conceito

eles: o número e a intensidade deles, o fluxo e o refluxo, o jogo recíproco e, sobretudo, as leis de sua alimentação, permanecem inteiramente desconhecidas para esse alguém. Esta alimentação será também obra do acaso: nossas vivências diárias lançam uma presa ora a esse, ora àquele impulso, que é avidamente apanhado, mas todo o ir-e-vir desse eventos está fora de qualquer nexo racional com as necessidades de nutrição da totalidade dos impulsos: de modo que sempre ocorrerão duas coisas, a inanição e o definhamento de uns e a excessiva alimentação de outros. Cada instante de nossa vida faz alguns dos braços do pólipo do nosso ser aumentarem e outros murcharem, conforme a alimentação que traz ou não traz o instante. Nossas experiências, como disse, são todas, nesse sentido, meios de alimentação, mas distribuídos com mão cega, sem saber quem passa fome e quem está saciado. E, devido a essa casual alimentação das partes, o pólipo crescido será algo tão casual como foi o seu desenvolvimento" (NIETZSCHE, 1881, aforismo 119, p. 91) 
de "vontade de poder" faz de Nietzsche o último metafísico. Não é nosso propósito saber se a vontade de poder tinha em Nietzsche um estatuto ontológico ou não. Mas apenas tentaremos elucidar melhor que Nietzsche possuiu um conceito de liberdade trágica, que está ligada ao conceito de vontade de poder, e que este, por sua vez, teve entre suas fontes inspiradoras o conceito de virtù de Maquiavel. Recentemente, Von Vacano destacou as ligações entre Nietzsche e Maquiavel e defendeu que o "conceito de virtù de Maquiavel ilumina o conceito de vontade de poder de Nietzsche" (VON VACANO, 2007, p. 98) ${ }^{32}$. Para Von Vacano, Maquiavel e Nietzsche têm em comum uma crítica a Platão e ao cristianismo, uma admiração pelos antigos em vista de criar algo novo, uma defesa da ética heroica, o entendimento de que um homem de virtù deve saber agir imoralmente se isto for necessário para alcançar um bem maior e ambos teriam um maneira estética de ver a política.

Entretanto, Von Vacano não estabelece uma diferença entre a ética heroica que ambos teriam e a ética trágica, que, pretendemos mostrar neste trabalho, é distinta tanto da ética heroica dos primeiros tempos na Grécia, quanto da ética racionalista inaugurada por Platão. O trágico, na verdade, é uma terceira via, algo que já era visível ao próprio Nietzsche, quando dizia que a arte trágica representava um equilíbrio entre o apolíneo e o dionisíaco, enquanto a epopeia era uma arte apolínea.

Outro problema que vimos no instigante trabalho de Von Vacano é que por vezes ele parece transformar Nietzsche em um libertarian, em um individualista que estaria nas antípodas daqueles que consideram o homem como um zoon politikon, entretanto, com isso, Von Vacano

\footnotetext{
${ }^{32}$ Ansell-Pearson também notou que Nietzsche foi muito influenciado por Maquiavel, especialmente pelo assim chamado realismo político, que considera que deve se aprender a ser imoral se isso for necessário, não apenas para se manter no poder, mas mesmo para sustentar uma moral ou defender o bem comum, que dizer, o realismo político como a visão atenta às bases imorais da moralidade. Outro aspecto que Ansell-Pearson destaca é a influência da noção de virtù de Maquiavel sobre Nietzsche: "There are a number of similarities between Machiavelli's notion of 'virtù' and Nietzsche's notion of 'will to power'" (ANSELL-PEARSON, 1991). Entretanto, Ansell-Pearson restringese a expor que as duas noções se referem à ação pública criativa que está além do bem e do mal, talvez essa insuficiência na análise se deva ao fato de que o foco do trabalho de Ansell-Pearson não era Maquiavel, mas as relações entre Nietzsche e Rousseau.
} 
esquece que, para Nietzsche, o "individualismo é o grau mais modesto da vontade de poder"

(NIETZSCHE, 1906, aforismo 784, p. 390) e que o elemento dionisíaco envolve a dissolução da individuação, enquanto o apolíneo uma afirmação da individualidade. Von Vacano também não leva em conta que Nietzsche em suas primeiras obras tinha um pensamento político semelhante ao "de Hegel e Rousseau, uma vez que desejava reavivar, em uma época dominada por um individualismo atomizado, um sentido peculiar à vida política grega, em que se ressaltava a disciplina política e concebia-se o indivíduo como parte de um todo orgânico" (ANSELL-PEARSON, 1997, p. 85). Embora o último Nietzsche tenha se afastado dos "exageros holistas", em virtude do crescimento dos círculos de nacionalistas e anti-semitas na Alemanha círculos vistos por Nietzsche como coisa de indivíduos "pouco viajados", ressentidos e movidos pelo ódio puro $^{33}$-, isto não significa que Nietzsche tenha aderido ao partido oposto de um individualismo liberal "atomista". Faltou também a Von Vacano uma análise mais cuidadosa sobre como o trágico afetou a teoria política de Maquiavel, sua visão do conflito civil e seu

\footnotetext{
${ }^{33}$ Há incontáveis momentos na obra de Nietzsche em que ele critica duramente o nacionalismo, o anti-semitismo e os alemães, assim como trechos em que ele defende o cosmopolitismo, demonstra preferência pelo sul da Europa, contra a Alemanha, e até mesmo demonstra preferência pelo catolicismo contra o protestantismo do norte. Em Gaia Ciência, 377, diz Nietzsche: "estamos longe de ser suficientemente 'alemães', como hoje é corrente a palavra 'alemão', para falar em prol do nacionalismo e do ódio racial, para poder nos regozijar do nacionalista envenenamento de sangue e sarna de coração, em virtude do qual cada povo da Europa de hoje se fecha e se tranca, como se estivessem todos de quarentena. Para isto somos demasiado diretos, maliciosos, mimados, também demasiado instruídos, 'viajados' (...) Nós, os sem-pátria, por raça e ascendência somos demasiado múltiplos e misturados, enquanto 'homens modernos', e, portanto, muito pouco inclinados a partilhar essa mentirosa autoadmiração e indecência racial, que agora desfila na Alemanha como sinal da mentalidade alemã e que, no povo do 'sentido histórico', é algo duplamente falso e obsceno" (NIETZSCHE, 1882, p. 281). Há muitos outros momentos na obra de Nietzsche com críticas ao nacionalismo, anti-semitismo e à teoria racial, mas, como esse não é o foco deste trabalho, queremos destacar uma carta de Nietzsche a Theodor Fritsch, um dos expoentes do movimento anti-semita na época. Na carta, escrita em 29 de março de 1887, Nietzsche pede para que Fritsch pare de lhe enviar o seu periódico anti-semita e escreve: “Acredite-me: esta desagradável invasão de enfadonhos diletantes que pretendem dizer a eles sobre o 'valor' dos homens e das raças, esta submissão às 'autoridades' que todas as pessoas sensatas condenam com frio desprezo ('autoridades' como: Eugen Dühring, Richard Wagner, Ebrard, Wahrmund, Paul de Lagarde - quem deles é o menos autorizado e o mais injusto nas questões da moral e da história?), estas contínuas e absurdas falsificações e distorções de conceitos tão vagos como 'germânico', 'semítico', 'ariano', 'cristão', 'alemão' tudo isto poderia enfim realmente encolerizar-me e me fazer perder a indulgência irônica com a qual até agora assisti as veleidades virtuosas e os fariseísmos dos alemães de hoje. - E, para terminar, o que o Senhor acredita que eu sinto quando alguns anti-semitas se permitem pronunciar o nome de Zaratustra?" (NIETZSCHE, citado em: MONTINARI, 1999, p. 57). Segundo Montinari, Nietzsche não diz nesta carta o que sentia quando anti-semitas usavam o nome de Zaratustra, mas, pouco depois, em outra carta escreveu Nietzsche: "Há algum tempo um certo Theodor Fritsch de Leipzig me escreveu. Não existe na Alemanha um grupo mais cínico e cretino do que estes antisemitas. Eu lhe desferi, como sinal de agradecimento, um belo pontapé como carta. Esta canalha ousa pronunciar o nome de Zaratustra. Nojo! Nojo! Nojo!” (NIETZSCHE, citado em: MONTINARI, 1999, p. 57)
} 
conceito de liberdade. Von Vacano concentrou-se mais nas afinidades entre Nietzsche e Maquiavel do ponto de vista de uma teoria estética da política e deu ênfase às obras literárias de Maquiavel em sua análise.

Apesar destas ressalvas, o livro de Von Vacano é instigante e tem o mérito de aprofundar a pesquisa sobre os laços entre Nietzsche e Maquiavel, que já haviam sido mencionados por Isaiah Berlin ${ }^{34}$ e por Ansell-Pearson (ANSELL-PEARSON, 1991). Nietzsche era um grande leitor e admirador de Maquiavel. O florentino foi citado em diversos momentos por Nietzsche, sempre em tom positivo ${ }^{35}$. Um dos aspectos mais visíveis da apropriação nietzscheana do pensamento de Maquiavel relaciona-se com o que Nietzsche chamou de "maquiavelismo do poder", em outras palavras, o "realismo político", que entende que toda moral só pode prevalecer por meios não morais; que para defender o "bem comum" ou algum ideal de sociedade, haverá momentos em que será necessário saber não ser moral; que o Estado nunca é fundado em contratos, e que a violência frequentemente é determinante na fundação ${ }^{36}$. Para os propósitos deste trabalho, o que queremos destacar é a sugestão de Von Vacano de que o conceito de vontade de poder de Nietzsche pode ser melhor compreendido à luz do conceito de virtù de Maquiavel. De fato, o próprio Nietzsche faz alusão ao tema:

“O que é bom? - Tudo o que eleva o sentimento de poder, a vontade de poder, o próprio poder no homem.

O que é mau? - Tudo o que vem da fraqueza.

O que é felicidade? - O sentimento de que o poder cresce, de que uma resistência é superada.

\footnotetext{
${ }^{34}$ Berlin destaca que Maquiavel e Nietzsche eram críticos do cristianismo e admiradores da moralidade pagã, que há um naturalismo presente em ambos (sem que isso signifique um naturalismo que ignora as determinações sociais) e que ambos descobriram que há "incompatibilidade de valores últimos", quer dizer, ambos estariam entre aqueles que destacam o "politeísmo de valores”. (BERLIN, 2002, p. 317 e 341)

${ }^{35}$ As citações mais importantes estão em: Além do Bem e do Mal, 28; A Vontade de Poder, 304; Crepúsculo dos Ídolos, $\mathrm{O}$ que devo aos antigos, 2. Nietzsche também refere-se indiretamente a Maquiavel em $O$ Anticristo, 2.

36 "Ela deve ser ensinada pela primeira vez com este tratado: que, simplesmente, a dominação da virtude só se pode conseguir por meio dos mesmos meios com os quais se consegue em geral qualquer dominação, em todo caso não por meio da virtude... Este tratado lida, como se disse, com a política na virtude: ele postula um ideal dessa política, a descreve tal como ela deveria ser, se algo sobre a Terra pudesse ser perfeito. Ora, nenhum filósofo duvidará de qual é o tipo da perfeição na política: a maquiavelismo. Mas o maquiavelismo pur, sans mélange, cru, vert, dans toute sa force, dans toute son âpreté é sobre-humano, divino, transcendente, jamais será alcançado pelo homem, no máximo tocado de leve... Também nessa forma mais estreita de política, na política da virtude, parece que o ideal jamais foi alcançado. Também Platão só o tocou ligeiramente” (NIETZSCHE, 1906, 304, p. 172)
} 
Não a satisfação, mas mais poder; sobretudo não a paz, mas a guerra; não a virtude, mas a capacidade (virtude à maneira da Renascença, virtù, virtude isenta de moralina)” (NIETZSCHE, 1888a, aforismo 2, p. 11)

Certamente, quando Nietzsche escreve "virtù isenta de moralina", não está se referindo aos humanistas cívicos que defendiam a concepção ciceroniana de virtude. Para Nietzsche, esta concepção estaria carregada de moral entendida como droga ("moralina"), como um remédio radical. A virtude que estaria ligada à vontade de poder seria a virtude como "capacidade" e "isenta de moralina", e foi Maquiavel que, na Renascença, elaborou esse conceito de virtù. Antes de continuarmos a investigar a relação entre virtù e vontade de poder, voltemos ao conceito de Nietzsche.

Em Nietzsche, o conceito de vontade de poder aparece após a "morte do fundamento", torna-se visível quando "não se pode mais subir ou descer a nenhuma outra realidade, exceto à realidade dos nossos impulsos" (NIETZSCHE, 1906, p. 39). Quando são eliminadas as "fícções substancialistas", diz Moura sobre a vontade de potência (Moura prefere "potência" em vez de “poder”), "restam na natureza apenas quantidades dinâmicas em uma relação de tensão com outras quantidades dinâmicas, e cuja essência consiste em sua relação com as demais quantidades, em seu atuar sobre elas" (MOURA, 2005, p. 197). Deleuze prefere colocar como "forças" em relação de tensão com outras forças. Quando Nietzsche diz que "o mundo é vontade de poder", refere-se ao mundo como sendo essa relação de tensão entre forças, com hierarquias provisórias de forças que se alteram quando surge um elemento diferencial de força, portanto, o eterno devir, é esse jogo de forças. A vida como parte desse mundo é vontade de poder. Um organismo vivo é um conjunto/resultante de forças que vive no mundo em relação com outros organismos, que são também conjuntos de forças. A vida como processo orgânico é essencialmente apropriação, exploração, cadeia alimentar. Um organismo precisa apropriar-se de outros, explorar, expandir-se, alcançar a preponderância, "não devido a uma moralidade ou imoralidade qualquer, mas porque vive, e vida é precisamente vontade de poder" (NIETZSCHE, 
1886, aforismo 259, p. 155).

Mas se a vida é essa relação de tensão na qual um organismo visa alcançar a preponderância, ela encontra limite em outras vidas, outras forças contrárias, nunca alcançando a preponderância definitiva, que eliminaria a vida. Por isso, segundo Moura, a estrutura fundamental visada pelo conceito de vontade de poder (potência) é "a limitação de uma ambição ilimitada", pois o conceito comporta dois momentos, o primeiro é a própria ambição ilimitada de potência, depois a limitação dessa ambição pela contraposição de outra ambição, que também visa ampliar-se, por isso, segundo Moura, “a determinação formal da noção de potência é um 'superar-se"”, e o "conteúdo essencial da vontade de potência está na ideia de 'superação de si"”, e o conceito nietzscheano de "além-homem" designa uma "perpétua superação de si", e, portanto, "nunca terá um rosto definido, nem poderia tê-lo" (MOURA, 2005, p. 199-200). Para Moura, a vida entendida como vontade de potência está mais no paradigma do jogo do que da guerra total e a inspiração de Nietzsche para construir seu conceito de vontade de potência estava, como já dissemos, nas suas investigações sobre "A disputa em Homero"37.

O que Moura não destaca é que existe um conceito de liberdade em Nietzsche e que esta liberdade é o desenvolvimento da vida, quer dizer, da vontade de potência entendida como superação de si. Na Vontade de Poder, Nietzsche relaciona "pulsão para o poder" com "liberdade":

“O mais terrível e profundo desejo do homem, sua pulsão [Trieb] para o poder - nomeia-se essa pulsão 'liberdade' - deve ser durante muito tempo limitada. Por isso a ética se constitui até aqui, com os seus instintos inconscientes de educação e cultivo, para manter nos limites o apetite de poder: ela difama o indivíduo tirânico e acentua o instinto de poder do rebanho, com a glorificação do cuidado e da assistência mútua, assim como do amor à pátria”. (NIETZSCHE, 1906, aforismo 720, p. 364)

Aqui, a liberdade é uma pulsão para o poder. Ela não é o oposto da necessidade, não

\footnotetext{
37 “É ali nas investigações sobre a disputa em Homero, no elogio à competição perpétua na Polis, na oratória ou nos concursos trágicos, que vai se forjando a ideia de vontade de potência como superação de si” (MOURA, 2005, p. 210)
} 
existe o "fora" do mundo da necessidade, portanto, a liberdade não pode ser uma liberdade abstrata, algo como o livre-arbítrio. A liberdade é o desenvolvimento da vida, a superação de si de um organismo, desenvolvimento de uma potencialidade imanente, sua pulsão para o poder. Essa pulsão é ilimitada, e, assim, é potencialmente autodestrutiva, por isso a "ética se constitui" para "manter nos limites o apetite de poder". Manter nos limites significa manter um determinado equilíbrio entre forças - não necessariamente uma neutralização - para que o jogo criativo da vida se desenvolva. A cultura e o cultivo de si podem contribuir para essa tarefa, mas é preciso que exista arena, pois os limites mais efetivos para uma vontade são outras vontades e com a resistência de uma vontade sobre a outra não apenas se fornece medida à pulsão para o poder, mas também se permite um aumento da força ${ }^{38}$, um desenvolvimento da vida, uma liberação de forças.

Von Vacano não desenvolveu o tema do individualismo em Nietzsche e sua relação com seu conceito de liberdade, o que teria mostrado uma ligação ainda maior de Nietzsche com Maquiavel e teria permitido um avanço na análise da relação entre virtù e vontade de poder (e teria permitido a Von Vacano entender que a vontade de poder em Nietzsche é o continuum da liberdade, como pretendemos mostrar). Na Vontade de Poder, Nietzsche diz que o “individualismo é o grau mais modesto da vontade de poder":

"O individualismo é o grau mais modesto da vontade de poder. (...) Quer-se a liberdade enquanto ainda não se tem o poder. Tendo-o, quer-se supremacia; não se a conquistando (sendo-se ainda fraco demais para ela), quer-se 'justiça', isto é, poder igual"' (NIETZSCHE, 1906, aforismo 784, p. 390)

O "individualismo" é o conseguir "livrar-se" - do Estado, da comunidade, dos outros - e é o grau mais modesto da vontade de poder. Esta maneira de colocar o problema remete à teoria dos humores de Maquiavel, que, como procuraremos mostrar na parte do trabalho sobre o florentino, está ligada à perspectiva "naturalista” de Maquiavel, que abandonou, como Nietzsche,

38 "A vontade de poder só pode externar-se em resistências; ela procura, portanto, por aquilo que lhe resiste" (NIETZSCHE, 1906, 656, p. 331) 
a visão judaico-cristã do cosmos e do homem. No momento, basta recuperarmos o trecho de $O$ Príncipe, livro tido em alta estima por Nietzsche, em que Maquiavel afirma que existem dois humores na cidade:

"Porque em toda cidade se encontram estes dois humores diversos: e nasce, disto, que o povo deseja não ser comandado nem oprimido pelos grandes e os grandes desejam comandar e oprimir o povo; e desses dois apetites diversos nasce na cidade um desses três efeitos: ou o principado, ou a liberdade, ou a licença" (MAQUIAVEL, 1513, IX, p. 105)

O povo tem o desejo de não ser oprimido, os grandes querem oprimir, e isto ocorre não porque o povo possua algum tipo de bondade natural, mas porque ainda não tem o poder. Tendoo, diria Nietzsche, "quer-se a supremacia", ou, nas palavras do florentino: "Os grandes desejam comandar". O primeiro humor move uma concepção de liberdade "negativa", não querer ser oprimido (o "conseguir livrar-se", segundo Nietzsche). "Livrar-se" é uma forma de negativa de liberdade. O segundo humor impulsiona uma liberdade "positiva", o "querer comandar". O continuum entre as duas liberdades é a pulsão para o poder, a vontade de poder. Nietzsche considerou o individualismo o grau mais modesto da vontade de poder, em um grau acima estaria a vontade de justiça, e, por último, na sua forma mais intensa, a vontade de poder aparece como "amor":

“Para o 'Maquiavelismo' do poder. A vontade de poder aparece

a) nos oprimidos, nos escravos de toda espécie, como vontade de 'liberdade': o mero conseguir livrar-se parece ser a meta (moral-religiosa: 'responsabilidade diante de sua própria consciência moral'; 'liberdade religiosa' etc.);

b) em uma espécie mais forte e que cresceu até o poder, como vontade de supremacia; quando ela não obtém sucesso de início, restringe-se então à vontade de 'justiça', isto é, à vontade da mesma escala de direitos que possui a espécie dominante;

c) nos mais fortes, mais ricos, mais independentes, mais corajosos como 'amor à humanidade', ao 'povo', ao evangelho, à verdade, a Deus; como compaixão; 'sacrifício de si' etc.; como dominar, arrebatar consigo, tomar a seu serviço; como um instintivo unificar-se com uma grande quantidade de poder, para a qual se é capaz de dar um direcionamento: o herói, o profeta, o César, o salvador, o pastor (- também o amor sexual tem aqui o seu domicílio: 
ele quer o domínio, o tomar posse, e aparece como um dedicar-se... (...) 'Liberdade', 'justiça', 'amor'!!!" (NIETZSCHE, 1906, aforismo 776, p. 386)

Neste aforismo, mais uma vez, a primeira forma de manifestação da vontade de poder corresponde ao humor do povo de Maquiavel, ao "não querer ser oprimido". Também permanece negativa a segunda forma, quando há um fortalecimento desse mesmo povo ou existe uma "espécie mais forte", nesse caso almeja-se a supremacia, não se a conseguindo, quer-se "justiça". O tempo inteiro o que temos aqui é uma correlação de forças. Na terceira forma, a vontade de poder vai além de sua forma burguesa, negativa, e torna-se positiva. Essa manifestação da vontade de poder é a manifestação que aparece no homem de virtù, no grande fundador no sentido de Maquiavel, quer dizer, no fundador de religiões, no "profeta armado" que funda um Estado, no patriota. É a vontade de poder ligada a um "instintivo unificar-se com uma grande quantidade de poder, para a qual se é capaz de dar direcionamento" (É como se Nietzsche estivesse dizendo que a "glória" é uma forma de vontade de poder mais intensa do que o autointeresse burguês). O homem de virtù é alguém que por suas habilidades, perspicácia, força de vontade, flexibilidade, é capaz de "dar direcionamento", dar forma, e, nesse sentido, o fundador e homem de virtù é como um artista, diz Nietzsche na Genealogia da Moral:

"No fundo é a mesma força ativa, que age grandiosamente naqueles organizadores e artistas da violência e constrói Estados, que aqui, interiormente, em escala menor e mais mesquinha, dirigida para trás, no 'labirinto do peito', como diz Goethe, cria a má consciência e constrói ideais negativos, é aquele mesmo instinto de liberdade (na minha linguagem: a vontade de poder): somente que a matéria na qual se extravasa a natureza conformadora e violentadora dessa força é aqui o homem mesmo, o seu velho Eu animal - e não, como naquele fenômeno maior e mais evidente, o outro homem, outros homens" (Nietzsche, 1887, II, 18, p. 76)

Mais uma vez, Nietzsche identifica "instinto de liberdade" com a vontade de poder. Antes deste trecho citado, Nietzsche escrevera sobre a fundação dos Estados, que teria ocorrido sempre por meio desses "artistas da violência” que são os fundadores, mas que criou um ambiente de paz no qual os impulsos agressivos tiveram que ser redirecionados, e o foram de uma forma que 
produziu a má consciência - “os instintos que não se voltam para fora voltam-se para dentro, contra o indivíduo" -, mas no fundo, para Nietzsche, é o mesmo "instinto de liberdade" (vontade de poder) que atua nos fundadores e na má consciência, apenas que nesta forma aparece em uma “escala menor e mais mesquinha". A má consciência é o "instinto de liberdade tornado latente à força", é um "instinto de liberdade reprimido, recuado, encarcerado no íntimo, por fim capaz de desafogar-se somente em si mesmo" (NIETZSCHE, 1887, II, 17, p. 75)

Quer dizer, o continuum entre "Liberdade" (negativa), "Justiça" e "Amor" (patriotismo, glória, liberdade positiva) é a vontade de poder. A virtù, portanto, corresponde às qualidades necessárias para a última dessas manifestações da vontade de $\operatorname{poder}^{39}$. Se o continuum da liberdade é a vontade de poder entendida como superação de si, a perda de liberdade é a neutralização da vida, que, segundo Nietzsche, tem entre seus militantes o "socratismo", as morais antinaturais ${ }^{40}$, o cristianismo e a civilização, enfim, todos aqueles que condenam o mundo, a vontade, a vida, em virtude dos seus sofrimentos, seja por cansaço ou "temor de rebanho", quer dizer, por enfraquecimento. Contra esse enfraquecimento nocivo à expansão da vida, em outras palavras, à liberdade, Nietzsche mobiliza as ideias de "cultura" (trágica), cultivo de si e uma noção de vida política como arena, em busca de uma forma de vida social vibrante, que libere as forças criativas e permita o surgimento de gênios.

Mas o que levou ao "enfraquecimento"? O que fez com que o remédio de Sócrates se tornasse necessário? Por que um remédio radical como o cristianismo teve tanto sucesso? Nietzsche sugere que a necessidade destes remédios radicais se deve a um tipo de desequilíbrio entre forças no interior da cidade e da cultura e a uma correspondente desordem dos instintos, que fez com que eles "entrassem em anarquia" e quisessem se fazer tiranos, produzindo um

\footnotetext{
39 Retornaremos a este ponto na parte sobre Maquiavel para tentar encontrar uma solução para os impasses interpretativos acerca da concepção de liberdade do florentino.

40 “Toda e qualquer posição naturalista na moral, isto é, toda e qualquer moral saudável, é dominada por um instinto de vida (...) A moral antinatural, ou seja, quase todas as morais que foram até aqui ensinadas, honradas pregadas, remete-se, de modo inverso, exatamente contra os instintos vitais" (NIETZSCHE, 1888, p. 36-7)
} 
excesso de sofrimento que, por sua vez, levará a um cansaço e a um clamor pela ausência definitiva de sofrimento. Na época de Sócrates, diz Nietzsche, esse desequilíbrio, desordem das vontades, já atingia os gregos, e “a velha Atenas caminhava para o fim”, prossegue Nietzsche:

"Por toda parte os instintos estavam em anarquia; por toda parte estava-se cinco passos além do excesso; o 'monstrum in animo' era o perigo universal. 'Os impulsos querem fazer-se tiranos; precisa-se descobrir um antitirano que seja mais forte'... (NIETZSCHE, 1888, p. 21-2)

O remédio de Sócrates foi fazer da razão um tirano mais forte do que os impulsos que entravam em anarquia, por isso Sócrates teria exercido fascínio, porque ele "parecia ser um médico, um salvador" (NIETZSCHE, 1888, p. 23). Na época de surgimento do cristianismo haveria uma "anarquia dos instintos" ainda mais intensa, visível na corrupção do final da República e início do Império Romano, portanto, havia um anseio por um remédio ainda mais radical que o de Sócrates: a castração dos desejos, instintos e paixões, operados pelo cristianismo, castração que aparece como última esperança daqueles que perderam completamente o autodomínio e estão “demasiado enfraquecidos em suas vontades":

“O mesmo remédio, a castração e a extirpação, é instintivamente escolhido no interior da luta contra o desejo por aqueles que estão demasiado degenerados, demasiado enfraquecidos em suas vontades, para poderem se impor uma medida nos desejos (...) Os remédios radicais só são indispensáveis para os degenerados” (NIETZSCHE, 1888, p. 34)

Quando o indivíduo perde a capacidade de se auto-impor uma medida nos desejos, estes podem provocar excesso de sofrimento. Mais uma vez, Nietzsche retoma a ideia de que a perda desta capacidade está relacionada à desordem da cultura, que ajuda a promover a desordem das forças no interior do indivíduo e uma contínua ausência da hierarquia entre essas forças. Caem os apoios (as belas ilusões) a partir dos quais essa hierarquia é mantida, quer dizer, os apoios que sustentam uma identidade. A dissolução das identidades é um dos resultados do dionisismo irrestrito. O sofrimento provocado por este gênero de desordem pode levar o sofredor a querer um remédio a qualquer custo, um remédio radical. Nesse sentido, não deixa de ser sugestivo que 
santo Agostinho tenha se convertido ao cristianismo após ter caído em "profunda sensualidade" e bebedeiras no norte da África, mas que pouco antes de sua conversão tenha dito: "Dai-me a castidade e a continência Senhor, mas não agora" (S. Agostinho, Confissões, VIII, 5,12). É algo comum que entre os mais fanáticos convertidos estejam pessoas que perderam a capacidade de se auto-impor uma medida nos desejos e sofreram demasiadamente com isso, como no caso dos que entraram em um processo autodestrutivo por meio do vício em álcool ou drogas. Para eles não é mais possível beber socialmente, precisam de um anti-tirano que seja mais forte e que corte o mal pela raiz. Entretanto, vimos que, para Nietzsche, os remédios radicais promovem uma perda da liberdade entendida como neutralização da vida.

É nesta chave que podemos compreender a visão de Nietzsche sobre as tragédias gregas, que não significavam para ele nem a hybris apolínea que paralisa a vida, nem a hybris dionisíaca, que leva à dissolução, e, consequentemente, à busca pela hybris oposta (o remédio radical). Como notou Gambino, as tragédias gregas forneceram para Nietzsche uma "terceira forma" de existência mundana capaz de curar a fratura entre a necessidade apolínea de limites e fronteiras e a dionisíaca afirmação da diversidade além dos limites ${ }^{41}$.

Segundo Nietzsche, há uma continuidade entre a poesia épica e as tragédias. Mesmo estas últimas ainda estão firmemente enraizadas na cultura helênica. $\mathrm{O}$ mundo de ambas é mais o mundo de Homero do que o de Platão ${ }^{42}$. Mas, enquanto na poesia épica existiria uma prevalência do elemento apolíneo, nas tragédias haveria um equilíbrio entre o apolíneo e o dionisíaco. Se a poesia épica surge no mundo da cultura arcaica e aristocrática, as tragédias surgem no auge da democracia ateniense. Enquanto a épica está embebida pelo aristocrático culto aos deuses

\footnotetext{
41 "Attic tragedy provided 'a third form' of worldly existence (BT 125). It did so not by resolving the contradictions of Greek culture into a rational unity, but by articulating in dramatic form the paradoxical relationships between these essentially contradictory principles. It was tragedy's capacity to heal the rift between the Apollinian need for limits and boundaries and the Dionysian affirmation of diversity beyond all limits, that provided the basis for political renewal." (GAMBINO, 1996, p. 430)

42 "Platão contra Homero: eis o verdadeiro, o inteiro antagonismo - ali, o mais voluntarioso 'partidário do além', o grande caluniador da vida; aqui o involuntário divinizador da vida, a natureza áurea" (NIETZSCHE, 1887, III, 25, p. 141)
} 
olímpicos (entre eles Apolo), as tragédias tem início como o culto popular e "oriental” de Dionísio.

Os termos apolíneo e dionisíaco, cunhados no Nascimento da Tragédia, referem-se a dois impulsos artísticos diferentes, mas que, ao mesmo tempo, são impulsos que irrompem da própria natureza. Para Nietzsche, o apolíneo está ligado ao princípio de individuação, a uma afirmação de limites, a um querer dar forma, em meio a um mundo em permanente transformação e sem finalidade. Do turbilhão do ser emergiriam belas formas, para em seguida desaparecerem. O dionisíaco é caracterizado como esse turbilhão, como as "mães do ser", o "uno primordial”, e o impulso dionisíaco relaciona-se à dissolução de todas as identidades neste fundo comum e indiferenciado do mundo, fundo que é uma fonte da criação marcada pela luta entre forças. Apolo era o deus da beleza, da moderação, da harmonia das formas e das medidas, das artes plásticas, enfim, da tentativa de enfrentar a temporalidade radical alcançando a imortalidade por meio das belas formas, esculturas, ações e palavras. Dionísio era um deus da vida e da morte, da desmedida, do sexo, da embriaguez, das metamorfoses, da dor e da música. O dionisismo permitiria aos gregos uma abertura para a riqueza da vida indiferenciada, além de todas as identidades estabelecidas.

Na poesia épica havia um predomínio do elemento apolíneo porque nela prevalecia a ética heroica que pretendia enfrentar a temporalidade radical por meio de grandes feitos a fim de alcançar "honra, glória e fama" imortais. Esta ética, espécie de individualismo aristocrático, apresenta-se, portanto, como uma estética da vida, pois a própria vida, pronta a ser sacrificada em nome da autoestima ${ }^{43}$ e da polis, é tomada como obra de arte, como performance. Os heróis queriam ser vistos em suas ações, eles atuavam. A noção de agon foi a resposta épica à questão

\footnotetext{
43 "Quem está impregnado de auto-estima deseja antes viver um breve período no mais alto gozo a passar uma longa existência em indolente repouso; prefere só um ano por um fim nobre, a uma vasta vida por nada; escolhe antes executar uma única ação grande e magnífica, a fazer uma série de pequenas insignificâncias". Grifos nossos. ARISTÓTELES. Ética a Nicômacos. 1169a. Brasília: Ed. Unb, 1985.
} 
do sofrimento e só pode ser compreendida pela noção de justificação apolínea do mundo da individuação ${ }^{44}$. Diante da temporalidade radical, dos sofrimentos, acasos, e da ausência em sua religião de um Deus único com um plano para nós, os gregos ainda assim afirmavam a vida e teriam entendido, segundo Nietzsche, que "só como fenômeno estético podem a existência e o mundo justificar-se eternamente" (NIETZSCHE, 1872, 5, p. 47). Os deuses, os mitos, a polis, a ânsia por imortalizar-se eram para os gregos suas "belas ilusões", sem as quais não é possível atuar $^{45}$, pois "para atuar é preciso estar velado pela ilusão" (NIETZSCHE, 1872, 7, p. 56), e também são as ilusões apolíneas que ajudam a sustentar as identidades, seja a do indivíduo ou do Estado/comunidade. Entretanto, a poesia épica em sua ânsia apolínea por afirmar uma forma, uma identidade, uma individualidade, procurava manter afastado o elemento dionisíaco, que implicaria na dissolução das identidades e na alegria sentida nesta dissolução.

Como observou Machado, Nietzsche elogiava a epopeia e admirava a "superabundância de forças própria do indivíduo heroico”, entretanto, suas análises sobre a epopeia são bastante reduzidas, "como se só existissem para esclarecer um saber bem mais importante e profundo do que o apolíneo: o saber trágico" (MACHADO, 2006, p. 210). Machado ressalta que Nietzsche nunca se denominou um filósofo apolíneo, mas sim dionisíaco, e teria feito isto por estar "atento aos limites de uma visão apolínea". Segundo Machado, os limites vistos por Nietzsche eram dois: a visão apolínea pode transformar-se em "socratismo" e a visão apolínea tal como aparece na epopeia não é uma afirmação integral da vida, pois ela afirma a vida apenas de modo

\footnotetext{
44 “Ora, essa noção de agon, resposta épica à questão do sofrimento, da crueldade, da morte, só pode ser compreendida profundamente pela noção de individualidade. Com isso quero dizer que o agon é o combate individual que dá brilho à existência, tornando a vida do indivíduo digna de ser vivida não pela busca de felicidade, como acontecerá a partir de Sócrates, mas pela busca do kleos, da glória. Nas ações heroicas do indivíduo que conquista a glória, a vida atinge a perfeição. A arte apolínea é uma justificação do mundo da individuação". (MACHADO, 2006, p. 204)

45 “Todas as forças da fantasia e do sonho apolíneo são salvas de seu vaguear ao léu somente pelo mito. As imagens do mito têm que ser os onipresentes e desapercebidos guardiões demoníacos, sob cuja custódia cresce a alma jovem e com cujos signos o homem dá a si mesmo uma interpretação de sua vida e de suas lutas: e nem sequer o Estado conhece uma lei não escrita mais poderosa do que o fundamento mítico, que lhe garante a conexão com a religião, o seu crescer a partir de representações míticas" (NIETZSCHE, 1872, 23, p. 135) Na parte sobre Maquiavel retomaremos este tema, na sua análise da importância da religião como "fundamento mítico".
} 
puramente apolíneo.

Nesse sentido, Homero seria expressão da maravilhosa "ingenuidade" grega dos primeiros tempos, que se alegrava na afirmação da individualidade, da forma, da aparência, enfim, na ingênua ilusão da eternidade da aparência. Entretanto, faltava à epopeia alegrar-se na própria dissolução para que a vida fosse afirmada por inteiro, e pudesse se abrir à inocência do devir e às potencialidades criativas. A hybris apolínea, em sua tentativa de manter uma forma, sufocava uma abertura em relação às potencialidades criativas da vida. Na política, segundo Nietzsche, o militarista governo de Esparta, tão admirado pelos filósofos, de Platão a Rousseau, era uma expressão desta hybris apolínea:

"Só consigo pois explicar o Estado dórico e a arte dórica como um contínuo acampamento de guerra da força apolínea: só em uma incessante resistência contra o caráter titânico barbaresco do dionisíaco podia perdurar uma arte tão desafiadoramente austera, circundada de baluartes, uma educação tão belicosa e áspera, um Estado de natureza tão cruel e brutal”. (NIETZSCHE, 1872, 4, p. 42)

É curioso que Nietzsche, um autor tão difamado por seu "aristocratismo", tenha demonstrado preferência por Atenas e não por Esparta, e tenha considerado a poesia épica como bela, mas inferior à tragédia, a qual Nietzsche reconhecia como tendo sua origem no povo, e não na nobreza:

“O ditirambo é canto popular e, na verdade, principalmente das camadas inferiores. A tragédia sempre conservou um caráter puramente democrático, pois ela surgiu do povo" Grifos nossos (NIETZSCHE, 1870, p. 56)

Nietzsche, que havia sido professor de filologia grega, sabia que as tragédias tinham origem nos ditirambos e cultos a Dionísio, que os gregos reconheciam como sendo um culto "novo" e de origem no oriente (o que depois foi contestado por alguns helenistas) e que, enquanto a religião olímpica era essencialmente aristocrática e associada ao culto doméstico das famílias nobres, a religião de Dionísio era popular e sem nenhuma exigência de status para a participação em seus cultos, que reuniam, em iguais condições, nobres, mulheres, escravos, 
estrangeiros, em uma autêntica dissolução carnavalesca de todas as identidades:

"A completa liberdade da natureza era restaurada por cinco dias; todas as relações sociais e políticas eram rompidas. Uma grande festa de liberdade e igualdade, na qual as classes servis recebem de volta seu direito original" (NIETZSCHE, 1870, p. 50)

Em vez da serenidade e moderação apolíneas, o culto dionisíaco era marcado pelo êxtase, frenesi, desmedida. Enquanto a epopeia era uma arte aristocrática em que prevalecia a apolínea afirmação da individualidade (das identidades), as tragédias seriam populares e com origem no culto a Dionísio, culto que em vez de afirmar a identidade, a separação de classes e de sexos, operava a dissolução de todas as identidades, promovendo assim a festa de reconciliação:

"Sob a magia do dionisíaco torna a selar-se não apenas o laço de pessoa a pessoa, mas também a natureza alheada, inamistosa ou subjugada volta a celebrar a festa de reconciliação com seu filho perdido, o homem. Espontaneamente oferece a terra as suas dádivas e pacificamente se achegam as feras da montanha e do deserto. O carro de Dionísio está coberto de flores e grinaldas: sob o seu jugo avançam o tigre e a pantera. Se transmuta em pintura o jubiloso hino beethoveniano à 'Alegria' e se não se refreia a força da imaginação, quando milhões de seres frementes se espojam no pó, então é possível acercar-se do dionisíaco. Agora o escravo é homem livre, agora se rompem todas as rígidas e hostis delimitações que a necessidade, a arbitrariedade ou a 'moda impudente' estabeleceram entre os homens. Agora, graças ao evangelho da harmonia universal, cada qual se sente não só unificado, conciliado, fundido com o seu próximo, mas um só, como se o véu de Maia tivesse sido rasgado e, reduzido a tiras, esvoaçasse diante do misterioso Uno-primordial. Cantando e dançando, manifesta-se o homem como membro de uma comunidade superior: ele desaprendeu a andar e a falar, e está a ponto de, dançando, sair voando pelos ares" (NIETZSCHE, 1872, 1, p. 31)

A alegria na dissolução era algo que faltava à arte puramente apolínea. Nas tragédias, segundo Nietzsche, além da afirmação apolínea, a alegria na dissolução também estaria presente, e a alegria na dissolução envolve um alegrar-se mesmo com o terrível, mesmo com a destruição do indivíduo, do herói que é a suprema manifestação da vontade, mas que é negado porque é "apenas aparência":

A alegria metafísica com o trágico é uma transposição da sabedoria dionisíaca instintivamente inconsciente 
para a linguagem das imagens: o herói, a mais elevada aparição da vontade, é, para o nosso prazer, negado, porque é apenas aparência, e a vida eterna da vontade não é tocada de modo nenhum por seu aniquilamento. 'Nós acreditamos na vida eterna', assim exclama a tragédia; enquanto a música é a ideia imediata dessa vida" (NIETZSCHE, 1872, 16, pp. 101-2)

Nietzsche, neste ponto, toca no tema da "consolação metafísica" que seria produzida pelas tragédias. Se a epopeia, puramente apolínea, procurava o prazer da existência nas aparências, nas identidades, a arte dionisíaca procura esse prazer "por trás das aparências":

“Também a arte dionisíaca quer nos convencer do eterno prazer da existência: só que não devemos procurar esse prazer nas aparências, mas por trás delas. Cumpre-nos reconhecer que tudo quanto nasce precisa estar pronto para um doloroso ocaso; somos forçados a adentrar nosso olhar nos horrores da existência individual - e não devemos todavia estarrecer-nos: um consolo metafísico nos arranca momentaneamente da engrenagem das figuras mutantes” (NIETZSCHE, 1872, 17, p. 102)

O consolo metafísico do dionisíaco, consiste em encontrar prazer na existência por trás das aparências, percebendo "que, sob o turbilhão dos fenômenos, continua fluindo a vida eterna" (NIETZSCHE, 1872, 18, p. 108). Nas tragédias, a justificação apolínea da existência aparece na figura do herói, nas belas ações, belas palavras, grandes feitos, mas, como Nietzsche escreve no trecho antes citado, até mesmo esse herói é "aparência" e ele é "negado para o nosso prazer". Como é possível um prazer deste gênero? Graças à consolação metafísica de que sob o turbilhão dos fenômenos continua fluindo a vida eterna. Afirmação apolínea e dissolução dionisíaca. Construir e desconstruir, e construir novamente. Com a reconciliação entre Apolo e Dionísio, operada pelas tragédias, a inocência do devir é restaurada, cessam as acusações contra a vida, o próprio mundo e a vida serão avaliados como fenômenos estéticos, como jogo, como brincadeira, tal como Heráclito já teria anunciado:

“Esse aspirar ao infinito, o bater de asas do anelo, no máximo prazer ante a realidade claramente percebida, lembram que em ambos os estados nos cumpre reconhecer um fenômeno dionisíaco que torna a nos revelar sempre de novo o lúdico construir e desconstruir do mundo individual como eflúvio de um arquiprazer, de maneira parecida 
à comparação que é efetuada por Heráclito, o Obscuro, entre a força plasmadora do universo e uma criança que, brincando, assenta pedras aqui e ali e constrói montes de areia e volta a derrubá-los" (NIETZSCHE, 1872, p. 142)

Para Nietzsche, a finalidade da tragédia é produzir nos espectadores esta sabedoria dionisíaca que aceita o sofrimento como parte integrante da vida e com isso não promove a busca por uma ausência de sofrimento definitiva e a qualquer custo, que tentaria atacar o sofrimento pela raiz, atingindo, ao mesmo tempo, as fontes de alegria. Despreocupar-se com o inevitável, aí estaria uma "grande liberação" capaz de nos fazer abandonar o imperativo do temor - que conduzia à neutralização da vida, quer dizer, neutralização da "liberdade", em nome da pacificação total. As tragédias, dessa forma, funcionariam como uma pedagogia trágica, que ensinaria aos espectadores certa dureza necessária para a liberdade, entendida como desenvolvimento criativo da vida, superação de si. A verdadeira mensagem trágica seria, portanto, a alegria. Segundo Deleuze:

"Trágico designa a forma estética da alegria, não uma forma medicinal, nem uma solução moral da dor, do medo ou da piedade. O que é trágico é a alegria. Mas isso quer dizer que a tragédia só apela para o medo e a piedade do espectador obtuso, auditor patológico e moralizante que conta com ela para assegurar o bom funcionamento das suas sublimações morais ou das suas purgações medicinais (E, com efeito, é necessário um verdadeiro renascimento para libertar o trágico de todo medo ou piedade dos maus auditores, que lhe deram um sentido medíocre originado na má consciência)" (DELEUZE, 2001, p. 29)

Se o trágico para Nietzsche designa a forma estética da alegria, como notou Deleuze, e a finalidade da tragédia é produzir a sabedoria dionisíaca - que implica em leveza, visão estética da vida e alegria, sem que isso signifique desviar o olhar diante do sofrimento e dos problemas mais duros -, Nietzsche vai se opor a todos aqueles que tentaram enxergar uma finalidade moral nas tragédias ${ }^{46}$. Por esse motivo, para Nietzsche, o papel da catarse produzida nas encenações

\footnotetext{
${ }^{46}$ É claro que Nietzsche está omitindo, neste caso, que sua crítica à moral se faz em nome da moral, de uma outra moral, é claro, mas a omissão é proposital, não podemos nos esquecer que Nietzsche é um combatente, que não teve paciência para a filologia, que gostava de filosofar com o martelo e sabia como manejar bem os instrumentos da retórica. Mesmo sua crítica ao cristianismo não significa uma rejeição completa, diversos comentadores notaram que alguns aspectos do pensamento nietzscheano são profundamente cristãos, como a ideia de sofrimento como meio de poder e a sua luta para livrar os homens do ressentimento, que remete à frase de Cristo na cruz quando disse diante
} 
trágicas não seria mostrar o triunfo da ordem moral no confronto do herói com o destino nem nos purgar dos afetos ou do medo e da compaixão, como pensava Aristóteles. Para Nietzsche, quem só tinha essas reações diante das encenações trágicas era o espectador obtuso, como escreveu Deleuze.

Para Nietzsche, se a arte trágica era em algum sentido um "remédio" que oferecia uma “consolação metafísica", certamente não era nem um purgante, nem um calmante, mas um tônico, como observou Machado ${ }^{47}$. Pensamos que a observação de Machado faz todo sentido à luz do aforismo 212 de Humano, Demasiado Humano, quando Nietzsche diz que concordaria com Platão em condenar as tragédias se ele considerasse, como Platão, que as tragédias tornavam os homens sentimentais e chorosos, o que indica que Nietzsche não apreciaria as tragédias se elas não fossem um "tônico" 48 . Entretanto, Nietzsche parece reconhecer que este tônico também excita os sentimentos, a compaixão e o temor, e considera que é bom que isso ocorra, pois a tragédia se dirigia a um público de "almas duras e guerreiras", as quais "convém serem amolecidas de quando em quando"49, o que nos mostra que o remédio de Nietzsche visava

daqueles que pediam a sua morte: "perdoa eles Senhor: eles não sabem o que fazem". Nietzsche estabelece uma diferença entre Cristo e o cristianismo, e condena o último. No Anticristo diz Nietzsche: " - Volto atrás, conto agora a história genuína do cristianismo. - Já a palavra cristianismo é um mal-entendido - no fundo, houve apenas um cristão, e ele morreu na cruz. O 'evangelho' morreu na cruz. O que desde então se chamou 'evangelho' já era o oposto daquilo que ele viveu: uma 'má nova', um disangelho" (NIETZSCHE, 1888a, 39, p. 45) A moral cristã que Nietzsche condena é a que, segundo ele, teria começado com Paulo e estaria carregada de ressentimento e ódio contra a vida. Segundo o tradutor de Nietzsche, Paulo César de Souza, no Posfácio de Ecce Homo, para Nietzsche, o próprio Cristo "não negou o mundo nem o afirmou, foi um 'idiota' no sentido grego: ignorou o mundo" (Souza em: NIETZSCHE, 1908, p. 125).

47 "ela é um remédio metafísico. Não um purgante, como Nietzsche interpreta a posição de Aristóteles, nem um calmante, como pensava Schopenhauer, mas um tônico, um estimulante capaz de fazer o espectador alegrar-se com o sofrimento e até mesmo com a morte porque a destruição da individualidade não é o aniquilamento do mundo, da vida, da vontade. Foi isso que Nietzsche chamou nessa época de 'consolação metafísica' proporcionada pela tragédia" (MACHADO, 2006, p. 240)

48 "Platão talvez tivesse razão em pensar que a tragédia nos torna mais medrosos e sentimentais, afinal. Então o próprio autor trágico adquiriria necessariamente uma visão do mundo sombria e medrosa, e uma alma tenra, suscetível e lacrimosa; também estaria de acordo com Platão, se os autores trágicos, e as comunidades inteiras que com eles se deleitam especialmente, degeneram numa crescente falta de medida e de freio" (NIETZSCHE, 1878, 212, p. 130) Uma das críticas de Platão as tragédias era que elas mostravam deuses e heróis chorando, desesperados, descontrolados, e isto poderia estimular falta de medida e poderia tornar os espectadores sentimentais e chorosos, o que não seria bom para a formação de bons cidadãos e guerreiros para a República.

49 "A tragédia se dirige a almas que sentem desse modo a compaixão, a almas duras e guerreiras, que dificilmente são vencidas, seja pelo temor, seja pela compaixão, para as quais é vantajoso, porém, serem amolecidas de quando em quando: mas de que serve a tragédia para os que se acham abertos às 'afecções simpáticas' como velas ao vento? Quando os atenienses tornaram-se mais moles e sensíveis, no tempo de Platão - ah, como ainda estavam longe da 
um equilíbrio: nem a dureza e sobriedade exigidas por Platão, nem um amolecimento excessivo que levaria ao "cansaço", à décadence, à perda de liberdade.

A morte da tragédia, para Nietzsche, ocorreu quando o espírito "socrático" penetrou na tragédia destruindo mitos - as belas ilusões -, buscando razões para o sofrimento, penetrando na interioridade dos personagens em busca de motivos, entendendo a finalidade da tragédia como purgação dos sentimentos, ou pior, defendendo sua submissão completa à razão, enfim, quando o espírito socrático preparou o terreno para o niilismo e a condenação da vida, teria começado o declínio das encenações trágicas. Esse declínio progressivo se faria sentir nos três grandes poetas trágicos: Ésquilo, Sófocles e Eurípides:

“A diferença mais rigorosa entre eles está expressa na frase de Sófocles: Ésquilo faz o melhor, sem o saber. Nisso está expresso o julgamento segundo o qual o próprio Sófocles, conscientemente, sucede a Ésquilo, enquanto pelo mesmo motivo Eurípides se contrapõe a ele. Sófocles caminha para além da trilha de Ésquilo: até então, era o instinto artístico da tragédia que a impulsionava; agora é o pensamento. Mas em Sófocles o pensamento no seu todo ainda está em concordância com o instinto; já em Eurípides ele torna-se destrutivo em relação ao instinto" (NIETZSCHE, 1870, p. 83)

Essa avaliação de Nietzsche sobre a morte da tragédia será criticada por comentadores de Nietzsche e por historiadores da tragédia. Kaufmann, um dos principais tradutores de Nietzsche para a língua inglesa, considerou que Nietzsche estava errado nesta avaliação, pois as tragédias não teriam morrido em virtude do "otimismo socrático", mas pelo clima desolador em Atenas depois de sua derrota na Guerra do Peloponeso, que desestimulava as encenações trágicas, que teriam feito sucesso no momento anterior, de grande entusiasmo cívico e identificação com os heróis (KAUFMANN, 1992, p. 166). Kaufmann também considera que Nietzsche foi injusto com Eurípides ${ }^{50}$, responsabilizado por ele pelos golpes finais contra a tragédia por meio de seu sentimentalidade de nossos citadinos! -, os filósofos já lamentavam a nocividade da tragédia" (NIETZSCHE, 1881, 172, p. 126)

50 "There is no evidence that Euripides was under the spell of Socrates, as Nietzsche claimed, and there is every evidence that he did not accept the three Socratic dicta of which Nietzsche says: 'In these three basic forms of optimism lies the death of tragedy' (...) While the superabundance of dialectical fireworks in some Euripidean tragedies dissipate our tragic emotions, it usually illustrates the futility of reason, its inability to prevent tragedy. At 
"socratismo", avaliação polêmica, e logo com Eurípides, que havia sido considerado por Aristóteles como "o mais trágico entre os poetas" (ARISTÓTELES, Poética, 2005, p. 32). Apesar desse erro histórico e da injustiça com Eurípides, Nietzsche considerou que em sua última peça, As Bacantes, Eurípides “tentou uma retratação” (NIETZSCHE, 1872, 12, p. 79), quer dizer, afastou-se do suposto "socratismo", e Nietzsche apreciava essa retratação, pois a a peça As Bacantes foi uma das fontes importantes para a sua compreensão do dionisíaco.

No Nascimento da Tragédia, Nietzsche ainda estava fortemente influenciado por Schopenhauer, entretanto, já neste livro promove uma transvaloração da concepção de seu antigo mestre - pessimista, negadora da vida e da vontade -, que entendia que a finalidade da tragédia era produzir resignação. Como confessa o próprio Nietzsche em Ecce Homo, já no Nascimento da Tragédia ele descobre que "a tragédia precisamente é a prova de que os gregos não foram pessimistas: Schopenhauer enganou-se aqui, como se enganou em tudo" (NIETZSCHE, 1908, p. 59). Depois de Humano, Demasiado Humano, Nietzsche segue distanciando-se de Schopenhauer, e na Tentativa de Autocrítica, que adicionou posteriormente no Nascimento da Tragédia, Nietzsche associa a necessidade de "consolo metafísico" a uma necessidade do cristão e do romântico e sugere que se aprenda a arte do consolo "daqui de baixo", que consiste em aprender a rir e "talvez, em consequência disso, como ridentes mandeis um dia ao diabo toda 'consoladoria metafísica - e a metafísica em primeiro lugar!" (Tentativa de Autocrítica, 7, em: NIETZSCHE, 1872, p. 23).

Apesar das transformações, há um continuidade na obra de Nietzsche, no dizer Sim à vida, "mesmo em seus problemas mais duros e estranhos", na sua concepção de liberdade "daqui de baixo", como superação de si, expansão criativa das forças vitais, enfim, na mensagem da alegria, por esse motivo ele se considerou o primeiro filósofo trágico ${ }^{51}$. Mesmo que Maquiavel antípoda de um filósofo pessimista" (NIETZSCHE, 1908, NT, 3, p. 61) 
não fosse um "filósofo" trágico, partilhava com Nietzsche um ponto de vista trágico sobre o cosmos, o homem e a liberdade, e apesar de "trágico", Maquiavel foi um escritor de comédias, ele já sabia rir, já conhecia a arte do consolo "daqui de baixo". Nietzsche teve que aprendê-la, teve que passar pela profundidade alemã para descobrir que só há superfície, o florentino, por sua vez, já sabia expor os assuntos mais sérios num “indomável alegrissimo”:

"Mas como poderia a língua alemã, mesmo na prosa de um Lessing, imitar o tempo de Maquiavel, que no seu Príncipe nos faz respirar o ar fino e seco de Florença, e só consegue expor o assunto mais sério num indomável allegrissimo - talvez com maliciosa percepção artística do contraste que ousa: os pensamentos, difíceis, prolongados, duros, perigosos, e um tempo de galope e do bom humor mais caprichoso" (Nietzsche, 1886, 28, p. $33)^{52}$

Dedicamos atenção maior ao trágico de Nietzsche porque pretendemos mostrar que o "trágico" de Maquiavel está mais próximo de Nietzsche do que de Hegel. Embora o trágico em Hegel também seja afirmativo como é em Nietzsche ${ }^{53}$, como tentamos mostrar, as diferenças entre os dois são substanciais. Consideramos que Eagleton está correto ao dizer que Hegel é o "maior teórico iluminista da tragédia", que Hegel tem uma "teoria não trágica da tragédia", enquanto Nietzsche é o maior filósofo trágico e crítico do iluminismo ${ }^{54}$. Entretanto, Eagleton, talvez por seu desconforto com a crítica ao iluminismo, atribui peso exagerado ao elemento

\footnotetext{
${ }^{52}$ No mesmo aforismo Nietzsche menciona que até Platão recorreu à comédia (de Aristófanes) como arte do consolo "daqui de baixo". Escreve Nietzsche: "nada me fez refletir mais sobre a reserva e a natureza esfíngica de Platão do que esse petit fait [pequeno fato], felizmente conservado: que sob o travesseiro do seu leito de morte não se encontrou nenhuma 'Bíblia', nada egípcio, pitagórico, platônico, - mas sim Aristófanes. Como poderia até mesmo um Platão suportar a vida - uma vida grega, à qual ele disse 'não' - sem um Aristófanes?” (NIETZSCHE, 1886, 28, p. 34)

53 "Far from being a catastrophe, tragic art for Hegel is supremely affirmative. It is the finest working model we have of how Spirit, once pitched into contention with itself, restores unity through negation" (EAGLETON, 2003, p. 42)

54 "Hegel is the great Enlightenment theorist of tragedy, seeking to rescue its depth, seriousness and intensity from sentimentalist dilutions, but striving at the same time to reconcile it with Enlightenment Reason. The great counterEnlightenment tragic philosopher is then Friedrich Nietzsche, who shares Kierkegaard's contempt for rationalism from a pagan rather than Protestant standpoint (...) If Hegel's non-tragic theory of tragedy is an unconscious defense against irreparable ruin, Nietzsche argues out loud for just this position. For him, tragedy is the supreme critique of modernity, which is one reason why the subject looms so large in an age undistinguished for its actual tragic art. It is a question of myth versus science, 'life' against morality, music versus discourse, eternity rather than progress, the ravishment of suffering in the teeth of a callow humanitarianism, heroism rather than mediocrity, the aesthetic at war with ethico-political, the barbaric against the civic and cultural, Dionysian madness contra Apollonian social order. It is a syndrome which has re-emerged in our own time in the shape of some postmodern theorizing, much of which has been Nietzschean without fully knowing it”. (EAGLETON, 2003, p. 52-53)
} 
dionisíaco em Nietzsche, esquecendo que o trágico, para Nietzsche, é um equilíbrio entre o apolíneo e o dionisíaco. A crítica ao iluminismo também não significa uma defesa do obscurantismo, que Nietzsche critica nos alemães do seu tempo e contra eles defende que temos que levar adiante um outro "gênero de iluminismo" (NIETZSCHE, 1881, 197, p. 142), de outra forma não seria compreensível seu entusiasmo pelos “espíritos livres”.

\section{Retornos contemporâneos do ponto de vista trágico}

No século $\mathrm{XX}$, um ponto de vista trágico na teoria política retorna em autores como Hannah Arendt, Claude Lefort e Castoriadis, que procuraram explicitamente recuperar o trágico para pensar a política, no contexto do pós- $2^{\circ}$ Guerra e da crítica dos totalitarismos. A recuperação do trágico teve papel importante na teoria democrática, ao destacar o pluralismo e a centralidade do conflito na política, e encontrou desenvolvimentos teóricos mais recentes entre os autores da corrente "agonística" da teoria democrática (MOUFFE, 2006; CONNOLY, 2000). Entre os autores denominados como "pós-modernos" também o trágico assume lugar de destaque. Maffesoli escreveu sobre um "retorno do trágico nas sociedades pós-modernas" (MAFFESOLI, 2008). Para Maffesoli, a modernidade estaria centrada na crença no poder ilimitado da razão; na ideia do indivíduo autônomo; em uma crença no progresso, derivada em última análise de uma filosofia da história com origem na metafísica judaico-cristã. A pós-modernidade, por sua vez, estaria assistindo a um retorno ao paganismo ${ }^{56}$, ao politeísmo de valores, a uma volta do tribalismo, sobre as anteriores pretensões de autonomia do indivíduo (MAFFESOLI, 1996), a um ceticismo em relação à crença no poder ilimitado da razão, a uma volta ao hedonismo, a um questionamento da ideia de que exista alguma finalidade para a história e a uma postura crítica

\footnotetext{
55 "Quando uma pessoa chega à convicção fundamental que tem que ser comandada, torna-se 'crente'; inversamente pode-se imaginar um prazer e força na auto-determinação, uma liberdade da vontade, em que um espírito se despede de toda crença, todo desejo de certeza, treinado que é em se equilibrar sobre tênues cordas e possibilidades e em dançar até mesmo à beira de abismos. Um tal espírito seria o espírito livre por excelência" (NIETZSCHE, 1882, 347 , p. 241)

${ }^{56}$ Neste ponto, Maffesoli concorda com Lyotard. Ver: LYOTARD, 1989.
} 
em relação à ideia de progresso e à sua identificação com a dominação da natureza.

Nesse sentido, para Maffesoli, as sociedades pós-modernas estariam assistindo a um "retorno à antiguidade" (MAFFESOLI, 2008, p. 324) e a modernidade é apresentada como um parênteses entre o paganismo antigo e a pós-modernidade. Para Maffesoli, este parênteses moderno teria suas origens no cristianismo. ${ }^{57}$ É no eclipse deste conjunto cultural de longa duração que o trágico retorna. Essa maneira inusitada de colocar o problema se assemelha à maneira como o próprio Maquiavel estabelecia a sua oposição entre os antigos pagãos e os modernos cristãos na introdução dos seus Discorsi. Maffesoli afirma, concordando com Fichte, que a "impiedade de Maquiavel" move-se contra esse tipo de cristianismo e que também é contra ele que se moveria a impiedade do presente pós-moderno. Quer dizer, em termos dos pressupostos cosmológicos e normativos inconscientes que organizam a visão de mundo dos indivíduos (e não de alguns filósofos), a oposição fundamental e mais geral seria entre o paganismo antigo e a tradição bíblica judaico-cristã.

Maquiavel, nos Discorsi, também considerou fundamentais as mudanças de religião, que ocorreriam "duas ou três vezes no espaço de cinco a seis mil anos" (MAQUIAVEL, 1519a, II, 5, p. 202). Mudanças que, “apagando a memória dos acontecimentos anteriores", alteram completamente a visão de mundo dos homens. Maquiavel não destaca a relevância politica das diferentes correntes filosóficas, pois parece considerar que elas ficariam restritas sempre a uma minoria dos homens, enquanto as mudanças na religião teriam um alcance muito maior, e, portanto, maior importância política. Posição semelhante a que terá Nietzsche, quando afirmou que o cristianismo seria uma espécie de "platonismo para o povo" (NIETZSCHE, 1886, p. 8), pois o platonismo, como escola filosófica, estava restrito a ter influência sobre uma parcela menor dos homens. É como se para eles as religiões tivessem maior sucesso do que a filosofia na

\footnotetext{
57 "For it is indeed the essence of Christianity that we find in the political project, in the economic conception of existence, or in the search for security that is advocated by various social institutions". (MAFFESOLI, 2008, P. 324)
} 
extensão e na solidez com que encobrem o "abismo" e seria assim inevitável manter uma distinção entre ensinamento esotérico e exotérico ${ }^{58}$. Sob este ponto de vista das oposições entre religiões, o trágico estaria do lado do paganismo e em antagonismo com a tradição bíblica.

Steiner também pensava que esta era a oposição fundamental. Por esse motivo, Steiner havia decretado a "morte da tragédia", ${ }^{59}$ porque na modernidade, as metafísicas do cristianismo e do marxismo, espécies de "notas de rodapé" do judaísmo ${ }^{60}$, seriam anti-trágicas por excelência, em especial por seu “otimismo". Se poderia questionar esse julgamento afirmando que tanto no judaísmo e cristianismo quanto no marxismo se entende a história como permeada por episódios trágicos e pela ideia de que certos sacrifícios e sofrimentos serão necessários para atingir um bem maior. Entretanto, para Steiner, uma visão instrumental do sofrimento não é suficiente para qualificar uma determinada posição de "trágica", pois pode-se aceitar o sofrimento como um meio episódico para a redenção final, que é tida como certa. Para Steiner, o livro de Jó, citado por muitos como um exemplo de visão trágica na bíblia, não seria realmente trágico, pois no final Deus compensou Jó por suas agonias e “onde há compensação não há tragédia". ${ }^{61} \mathrm{~A}$ concepção cristã conheceria apenas "a tragédia parcial ou episódica". Os momentos de desespero, os retrocessos cruéis, podem acontecer, mas, diz Steiner, “é como um provérbio português, 'Deus escreve certo por linhas tortas'” (STEINER, 1961, p. 188).

Nessa visão, de origem judaica e ausente no paganismo, o sofrimento sempre tem que ter

\footnotetext{
${ }^{58}$ Será este o sentido de Zaratustra ter resolvido "descer" da montanha em que permanecera por dez anos para tornar-se "novamente" homem, trazendo uma "boa nova" aos outros, desta vez favorável à vida? Lampert considera que em Assim falou Zaratustra, Nietzsche inspira-se em Maquiavel e que o Zaratustra seria um fundador no sentido maquiaveliano (LAMPERT, 1986, p. 263).

59 “As metafísicas do cristianismo e marxismo são anti-trágicas. Esse é, em essência, o dilema da tragédia moderna". (STEINER, 1961, p. 184).

${ }^{60}$ Afirmação de Steiner no final de sua exposição no Centro de Estudos Europeus em 10 de maio de 2006.

${ }^{61}$ "A tragédia é alheia à percepção judaica do mundo. O livro de Jó é sempre citado como uma instância da visão trágica. Mas essa fábula negra pertence ao outro extremo do judaísmo (...) O Senhor devolveu em bens a destruição enviada ao Seu servidor; Ele compensou Jó por suas agonias. Mas onde há compensação, há justiça, não tragédia. Essa demanda por justiça é o orgulho e o túmulo da tradição judaica". (STEINER, 1961, p. 1) A ideia de que a tragédia não oferece "nenhuma compensação" não era compartilhada nem por Aristóteles, já que a catarse oferecia alguma compensação, nem por Nietzsche, que entendia a tragédia como um tônico que ensinava a sabedoria dionisíaca, a alegria e um equilíbrio entre o apolíneo e o dionisíaco.
} 
um sentido, o sofrimento normalmente aparece como um castigo resultante de uma falha moral, portanto, o sofrimento seria em tese superável. Sodoma e Gomorra foram destruídas como castigo pelas práticas imorais de seus habitantes. Portanto, sabendo disso, nós ainda podemos evitar desastre semelhante. Os poetas trágicos, por sua vez, "afirmam que as forças que modelam ou destroem nossas vidas estão fora do controle da razão e da justiça" (STEINER, 1961, p. 3). Assim, as tragédias partiriam de uma base ontológica totalmente distinta, cujo núcleo constante estaria na ideia de que o homem é "um hóspede não desejado da vida, um estrangeiro numa terra hostil e indiferente" (STEINER, 2008, p. 30).

O marxismo seria, para Steiner, ainda mais anti-trágico do que o cristianismo. A marcha adiante rumo à emancipação humana teria a seu favor as "leis da história" e a vitória final seria certa. Para Steiner, a visão marxista seria ingenuamente otimista, portanto anti-trágica. ${ }^{62}$ Para Raymond Williams e Terry Eagleton, essa visão de Steiner só atinge o "marxismo vulgar", determinista, e o marxismo não se resumiria a isto. ${ }^{63}$ Entretanto, para Steiner, não é apenas na "marcha da história" que está presente o otimismo no marxismo, mas em todo um conjunto de pressupostos derivados do racionalismo, que estaria bem expresso na afirmação de Marx de que "a necessidade é cega somente na medida em que não é compreendida". Para os poetas trágicos a necessidade seria cega, e só. Nossa compreensão seria limitada e nem sempre existiria uma solução a ser encontrada pela razão. Nem todas as causas de sofrimento são vistas como históricas ou sociais, quer dizer, nem todas essas causas poderão ser superadas.

Para Steiner, o personagem trágico é rompido por forças que não podem ser totalmente compreendidas ou superadas e "onde as causas do desastre são temporais, onde o conflito pode

\footnotetext{
62 "Além do mais, o credo marxista é imensamente, talvez ingenuamente, otimista. Como o visionário medieval, com sua fé absoluta no advento do reino de Deus, o comunista tem certeza que o reino da justiça se aproxima da terra. (...) Quando a exploração capitalista terminar, e o Estado for abolido, a guerra e a pobreza desaparecerão num pesadelo de lembrança sombria, e o mundo será novamente um jardim para o homem". (STEINER, 1961, p. 193).

${ }_{63}$ "It is thus a mistake to believe with George Steiner that Christianity is inherently anti-tragic. Steiner makes the same mistake about Marxism, for much the same reasons". (EAGLETON, 2003, p. 39). Ver também: (WILLIAMS, 2001).
} 
ser resolvido por meios técnicos ou sociais, podemos ter drama sério, mas não tragédia" (STEINER, 1961, p. 4), pois “a tragédia não fala sobre o dilema secular a ser solucionado pela inovação racional, mas das tendências permanentes da desumanidade e destruição no curso do mundo" (STEINER, 1961, p. 166). É curioso que Steiner tenha sido influenciado por Nietzsche, mas parece ter perdido o traço afirmador do trágico nietzscheano. Como tentamos mostrar, para Nietzsche, a tragédia não seria algo essencialmente triste, mas algo que nos elevaria, a pedagogia trágica nos ensinaria a amar a vida inteira, funcionando como um tônico que nos prepara para a liberdade.

A posição de Steiner sobre as tragédias e sobre o trágico tornou-se clássica. Entretanto, diversas críticas foram feitas. A incompatibilidade entre o cristianismo e o trágico é polêmica. Lesky concorda com Steiner quanto ao cristianismo ser incompatível com uma "visão cerradamente trágica do mundo", na qual o mundo é visto "como sede da aniquilação absoluta de forças e valores que necessariamente se contrapõem, inacessível a qualquer solução e inexplicável por nenhum sentido transcendente" (LESKY, 2006, p. 38). Entretanto, o cristianismo não seria incompatível com “conflitos trágicos cerrados" nem com "situações trágicas". ${ }^{64}$

A definição de trágico de Steiner é considerada por Eagleton tão "cerrada", que mesmo muitas das tragédias gregas não seriam consideradas trágicas por Steiner, pois diversas tragédias gregas admitiam reconciliação final, em especial as de Ésquilo, o mais tradicional e otimista dos três grandes poetas trágicos. O paradoxo é admitido pelo próprio Steiner ${ }^{65}$, portanto, sua concepção do trágico seria melhor compreendida como um tipo ideal. Eagleton caracteriza a posição de Steiner como uma posição aristocrática, que expressaria uma "nostalgia patrícia"

\footnotetext{
64 "Sem dúvida, em circunstância alguma é possível coadunar uma visão cerradamente trágica do mundo com a cristã, sendo ambas mesmo diametralmente opostas. Em compensação, a possibilidade da situação trágica dentro do mundo cristão se dá como em qualquer outro mundo". (LESKY, 2006, p. 41)

${ }^{65}$ Para Steiner, apenas cinco tragédias gregas enquadram-se no seu conceito de tragédia absoluta: Os sete contra Tebas, Édipo Rei, Antígona, Hippólito e As Bacantes.
} 
conservadora e incapaz de entender as conquistas da modernidade. Essa visão aristocrática valoriza a performance do herói que enfrenta o destino, que mostra seu valor mesmo na queda (a dignidade da queda), sem recorrer a nenhum consolo metafísico, a nenhuma forma medicinal. Para Eagleton, essa visão menosprezaria o sofrimento real do homem comum, que não seria considerado trágico por não possuir esse lado afirmativo do enfrentamento com o destino, ou da luta da virtù contra a fortuna, para usar os termos de Maquiavel. Steiner admite que as tragédias de "Ésquilo a Shakespeare, de Sófocles a Racine, retratam as desventuras dos privilegiados", elas envolvem uma "aristocracia do sofrimento", mas, segundo Steiner, isso não teria nenhuma relação com “esnobismo ou patronagem” (STEINER, 2008, p. 37).

Para Kaufmann, a posição de Steiner sobre o trágico comete "o mesmo erro de Nietzsche", que consistia em definir o trágico em oposição ao otimismo dos filósofos e à tradição judaico-cristã. O que define o trágico não é otimismo ou pessimismo. As tragédias gregas seriam mais otimistas que as comédias gregas. Kaufmann salienta que as tragédias gregas foram escritas no auge da democracia ateniense e no auge do poder de Atenas, depois das vitórias de Maratona e Salamina, portanto, em um momento de otimismo, de simpatia e identificação com os heróis. A "morte da tragédia" não se deu porque os homens se tornaram mais sensíveis ao sofrimento e buscaram consolo no otimismo dialético de Platão e seu "mundo verdadeiro". Para Kaufmann, a "morte da tragédia" foi decorrente da derrota na guerra do Peloponeso. A tragédia "seria inspirada pela fé de que podemos enfrentar com coragem as desgraças" e "a tragédia é compatível com as grandes vitórias como a batalha de Salamina ou a vitória inglesa sobre a invencível Armada espanhola, que inaugurou a Era de Shakespeare, mas não com Dresden, Hiroshima e Nagasaki” (KAUFMANN, 1992, p. 166). Depois da derrota na Guerra do Peloponeso as tragédias deixaram de ser encenadas. Após a segunda Guerra Mundial, o "profundo desespero" levou muitos da geração pós-guerra a dizerem que a "tragédia era 
datada" e eles "preferiam a comédia" (KAUFMANN, Id).

De qualquer forma, nenhum desses comentadores das tragédias e do "trágico" deixa de observar a existência de tensões entre o trágico de um lado, e a tradição judaico-cristã e socrático-platônica, de outro lado. Ainda que alguns deles não cheguem a caracterizar o trágico em oposição absoluta com essa grande tradição ocidental, como havia feito Steiner e outros teóricos da "morte da tragédia" ${ }^{66}$ Tentaremos esclarecer melhor essa oposição construindo um tipo ideal do que seria um ponto de vista trágico. Faremos isto a partir de um pequeno mapeamento das fontes do trágico na cultura antiga. Isto porque os trágicos modernos buscaram na cultura antiga fontes de inspiração para suas posições, e a denominação "trágico" refere-se explicitamente ao gênero artístico surgido na Grécia. Que elementos da cultura antiga foram de interesse especial para os trágicos modernos? Depois de encontrar esses pontos comuns ao “ponto de vista trágico" mostraremos como eles aparecem em Maquiavel ${ }^{67}$, pois o que nos interessa é reconhecer que o pensamento de Maquiavel possui elementos comuns ao ponto de vista trágico e que isso afeta a sua maneira de entender a política e a liberdade.

\footnotetext{
${ }^{66}$ Entretanto, é conveniente registrar que nem mesmo Steiner se fechou a reconhecer possíveis relações entre os dois pólos, pois considerou o calvinsimo como uma espécie de cristianismo trágico, com sua teoria da predestinação, entendida por ele como uma variante do "fatalismo antigo". Ver: STEINER, 2008, p. 34.

${ }^{67}$ Maquiavel chegou a se autodenominar trágico ao assinar uma carta a seu amigo Guicciardini como "Nicolau Maquiavel, historiador, cômico e trágico". Entretanto, não é possível deduzirmos um significado maior do trágico apenas por meio desta carta. A carta foi escrita em 21 de outubro de 1525. Ver em: MAQUIAVEL, 1989, p. 987.
} 


\section{CAPÍTULO 2 - FONTES DO PONTO DE VISTA TRÁGICO NA}

\section{CULTURA ANTIGA}

As fontes do trágico na cultura antiga devem ser procuradas na religião pagã e nos poemas de Homero e Hesíodo. Platão talvez tenha sido o primeiro a registrar que, quanto ao conteúdo, a origem das tragédias estava em Homero, ainda que, em relação à forma, Homero tenha sido um poeta épico, portanto, anterior ao surgimento do gênero teatral da tragédia propriamente dita ${ }^{68}$ Aristóteles é que fez uma distinção mais rígida entre a poesia épica e a tragédia, porque ele está interessado na discussão artística e Platão principalmente no conteúdo do trágico, ao qual ele dirige sua crítica. Essa posição de Platão que busca as origens do conteúdo do trágico em Homero é amplamente aceita entre os comentadores modernos, que possuem algumas divergências em relação ao tipo de continuidade e de ruptura entre Homero e as peças trágicas, mas não negam que exista essa relação. Como nós queremos delimitar o "ponto de vista trágico" e como ele afeta à teoria política, nos concentraremos em mapear o “conteúdo" do trágico, em vez de fazer uma discussão detalhada das peças trágicas.

\section{COSMOLOGIA TRÁGICA}

\section{Caos e ordem}

\footnotetext{
"Sim bem primeiro nasceu o Caos, depois também

Terra de amplo seio, de todos sede irresvalável sempre, dos imortais que têm a cabeça do Olimpo nevado, e Tártaro nevoento no fundo do chão de amplas vias, e Eros: o mais belo entre deuses imortais solta-membros, dos Deuses todos e dos homens todos ele doma no peito o espírito e a prudente vontade" (HESÍODO, Teogonia, 1995, p. 111)
}

68 “Homero é o melhor poeta e o primeiro entre os t 
A religião politeísta grega não possuía uma Igreja, quer dizer, não possuía uma instituição que congregasse uma classe sacerdotal que tivesse o monopólio exclusivo da interpretação do divino. Também não possuía um livro considerado como "revelado" pela divindade. Desse modo, muito do que conhecemos sobre a religião pagã antiga provém da obra dos poetas. Em Homero, há uma cosmogonia e uma cosmologia, mas, como em outros textos gregos, elas não são sistemáticas. Para Vernant, é como se "tradições concorrentes e paralelas tivessem deixado sobrar apenas os cacos”, já com Hesíodo, a cosmogonia e cosmologia foram apresentadas de modo mais sistemático e eram mais "religiosas", quer dizer, possuíam em menor grau o aspecto de livre produção literária que existia em Homero $^{69}$. No trecho acima citado, da Teogonia: $a$ origem dos deuses, Hesíodo afirma que o universo foi formado a partir de quatro elementos e o primeiro deles é o Caos.

Caos, o primeiro dos elementos primordiais, não desaparece após o surgimento dos outros elementos (Terra, Tártaro e Eros). Caos permanece subjacente a eles e continua a reinar soberano nas raízes do universo. Se primeiro veio o Caos, significa que no princípio reinava a desordem mais brutal e que somente depois é que a ordem do cosmos teria sido introduzida. Todavia, essa ordem do cosmos que começa com o aparecimento da Terra (Gaia) e é concluída com o poder soberano de Zeus, não elimina o $\operatorname{Caos}^{70}$, que pode irromper a qualquer momento, pois a qualquer momento pode irromper uma catástrofe, uma doença repentina e mortal, um

\footnotetext{
69 "Mas, com relação a essas tradições um pouco secundárias, marginais ou explodidas, o poema teogônico de Hesíodo apresenta-se tal como nos foi transmitido em sua forma de obra completa e sistemática, como o testemunho central, o documento mais importante de que dispomos para entender o pensamento mítico dos gregos e suas orientações mestras no campo cosmogônico". VERNANT, 1996, p. 241.

70 "Mas Gaia não é a primeira; Chaos precedeu-a, como uma realidade que lhe é estrangeira, a única força com a qual Gaia não se unirá de nenhuma maneira. É dizer que mesmo ao termo dessa sequência de gerações e de lutas divinas que terminarão no estabelecimento da ordem, Chaos não deixará de representar uma ameaça que subsiste em segundo plano e que correria o risco de submergir tudo o que o cosmo comporta de estável e organizado". VERNANT, 1971, p. 266.
} 
acidente sem sentido, e estes acontecimentos podem destruir, aleatoriamente, as paisagens mais belas, os animais mais extraordinários, as pessoas mais justas. Caos não é apenas desordem, mas uma desordem inominável presente no mais recôndito do mundo, e a expressão desta essência caótica no interior do indivíduo em um certo sentido é a hybris. ${ }^{71}$

Para Vernant, apesar de Hesíodo listar quatro elementos primordiais, na verdade seriam apenas três: Caos, Terra e Eros. Isso porque Tártaro representaria, em seu fundamento, a "mesma abertura original, o mesmo abismo vertiginoso" de Caos. Caos está em uma relação de oposição e complementaridade com Gaia (Terra). Enquanto Caos é abertura, ausência de ordem, de forma, de estabilidade, Gaia é "de todos sede irresvalável sempre”, é a base sólida a partir da qual o mundo se constitui. Para Vernant, a "dependência de Gaia frente a Caos é muito mais complexa do que a do ser frente ao não-ser" e Caos não seria "simplesmente o negativo de Gaia", pois "Ele produz a luz sem a qual nenhuma forma seria visível. Inversamente, Gaia, que gera tudo o que tem densidade e figura, é também qualificada de dnophera (736), epíteto de $N y ́ x$ (101): é a terra escura, a terra preta" e entre as duas entidades primordiais "existem passagens, caminhos, encontros", entretanto, apesar das ligações, "nenhum filho da descendência de Caos dormirá com um filho de Gaia" (VERNANT, 1996, p. 246.

No início, Caos e Gaia gerarão filhos a partir de si mesmos, sem união sexual. Gaia gerou Céu (Urano), e, como sinal de afinidade com ele, gerou altas montanhas e "quem diz montanhas também diz vales (não existe montanha sem vale, assim como não existe caos sem terra, terra sem céu, escuridão sem luz)" e esses vales servirão de morada para as ninfas. Também de si, Terra gerou "seu duplo e contrário líquido, Ponto, Onda marinha, cujas águas são ora de uma claridade límpida (atrýgetos), ora escurecidas por caóticas tempestades” (VERNANT, 1996, p.

\footnotetext{
71 "El Caos nos es simple desorden. Hay, en lo más recóndito del mundo, un Caos como desorden innombrable. (...) Más aún, expresión de la esencia caótica, no nombrada, de lo recóndito humano, la hybris, en un sentido, forma parte del mecanismo de restauración del orden puesto que, empujando hasta el exceso, provoca la catástrofe que es restablecimiento. Pero este restablecimiento no es ni consuelo ni expiación. Es simplemente lo que es. No hay ninguna relación entre la hybris griega y el pecado judeo-cristiano. La hybris no transgrede ningún mandamiento o ley, humano o divino". CASTORIADIS, 2006, p. 340.
} 
247) e assim se encerra a primeira fase da cosmogonia. A partir daí Gaia gerará descendentes por união sexual e dos abraços com Urano (céu) Gaia engendra três séries de filhos: “os doze Titãs e titânides, os três Cíclopes, os três Cem-Braços". Na ninhada dos Titãs estava Cronos, o mais novo, que será rival direto de Zeus na luta pelo reino do céu. Cronos luta contra o pai (Urano/céu), e, com um golpe de foice corta seus órgãos sexuais. Esse ato de violência separa para sempre o Céu e a Terra. Quando Cronos atira para trás o órgão sexual de Céu, gotas de sangue caem sobre a Terra (Gaia) e o esperma cai sobre as Ondas líquidas de Ponto, que o carrega para alto mar. Do sangue que fecundou Gaia nascem "três grupos de potências divinas: as que são encarregadas de perseguir a vingança, a punição dos crimes cometidos contra os pais (Erínias), aquelas que apadrinham os empreendimentos guerreiros, as atividades de luta, as provas de força". Do esperma caído no mar forma-se uma espuma e desta nasce Afrodite, e assim que ela põe os pés em Chipre é cortejada por Amor (Eros) e Desejo (Hímeros) e suas atribuições entre os mortais e imortais serão "as conversas de meninas, os sorrisos, os ardis, o prazer, a união amorosa" (VERNANT, 1996, p. 250).

Como notou Vernant, a castração de Urano engendrou sobre a Terra e sobre Onda "duas ordens de consequências, inseparáveis em sua oposição: de um lado, violência, ódio, guerra; do outro, suavidade, concórdia, amor” (VERNANT, 1996, p. 251). A própria união sexual, com Afrodite, deixa de ser uma união cósmica como era com o Eros primordial, e passa a se exercer pela diferenciação de sexos contrários e "o mundo vai se organizar por mescla de contrários, por mediação entre os opostos" (VERNANT, 1996, p. 252). O ato de violência que afastou Urano "desbloqueou o curso do tempo, equilibrou os contrários na procriação", e é também o ato no qual "convergem e como que se confundem a obscura potência primordial de Caos e as jovens divindades cujo nascimento marca o advento de uma nova ordem do mundo". Para Vernant, isso quer dizer que o "crime de Crono coloca a rebelião e a desordem como fundamentos da ordem" 
(VERNANT, 1996, p. 253). ${ }^{72}$ Depois, caberá a Zeus liderar a guerra contra os Titãs e estabelecer a sua soberania.

Um aspecto derivado desta cosmogonia e cosmologia que fornecerá elementos importantes para o "ponto de vista trágico" é a visão de que a "ordem do cosmos", construída sobre o Caos, não é uma ordem plenamente previsível ou estável. Embora preenchida pela necessidade, por regularidades, por fenômenos inevitáveis (como o nascimento e corrupção de todas as coisas), não se elimina o acaso. O que se tornou necessidade pode ter sido fruto de um acaso. O que se tornou o "destino" de um indivíduo pode ser uma combinação de acasos. É nas peças de Eurípides que esta característica - o acaso sem sentido - aparece com maior destaque, um dos motivos para Aristóteles tê-lo chamado de "o mais trágico entre os poetas". ${ }^{73}$ Mas a força do "acaso" também aparece nas obras de outros poetas trágicos. Por exemplo, em Édipo Rei, de Sófocles, quando Jocasta diz:

"JOCASTA:

O medo em tempo algum é proveitoso ao homem.

O acaso cego é seu senhor inevitável

e ele não tem sequer pressentimento claro

de coisa alguma; é mais sensato abandonarmo-nos

até onde podemos à fortuna instável.

Não deve amedrontar-te, então, o pensamento

dessa união com tua mãe; muitos mortais

em sonhos já subiram ao leito materno.

Vive melhor quem não se prende a tais receios"

Sófocles. Édipo Rei, 1165.

\footnotetext{
${ }^{72}$ Curiosa afinidade com a visão de Maquiavel sobre a desordem como fundamento da ordem: "Todas as leis para proteger a liberdade nascem da sua desunião, como prova o que aconteceu em Roma (...) pois os bons exemplos nascem da boa educação, a boa educação das boas leis, e estas das desordens que quase todos condenam irrefletidamente”. MAQUIAVEL. 1519b, p. 31.

73 "Eurípides, embora não tenha em geral uma boa economia, se mostra o mais trágico dos poetas". ARISTÓTELES, 2005 , p. 32.
} 
Uma das consequências de dizer que o universo está fundado sobre uma relação entre necessidade e acaso é que não há uma finalidade última da existência, nem uma compensação final para os indivíduos que nascem e forçosamente terão que morrer, independente de qualquer relação com a justiça. A ausência de compensação em "outro mundo" também está relacionada com o fato de que a religião pagã das cidades-estado gregas e de Roma, com exceção de alguns cultos marginais, não acreditava na vida após a morte e em alguns escritos em que aparece essa possibilidade, como na revelação de Aquiles a Odisseu no "País dos Mortos", na Ilíada, a vida depois da morte era pior do que a pior vida na Terra. ${ }^{74}$ Outra consequência, tanto da ideia de acaso quanto da noção de destino, do ponto de vista existencial, é que ambos oferecem uma libertação para o indivíduo, o que parece paradoxal aos modernos, que entendem o destino como o oposto de qualquer libertação, pois pretendem salvar a noção de livre-arbítrio e tornar o indivíduo responsável por seus atos, que dizer, pretendem torná-lo culpado. Já a fala de Jocasta, no trecho acima citado, pretende libertar Édipo do peso da culpa apelando à ideia de acaso cego e termina sua fala dizendo que "vive melhor quem não se prende a tais receios".

Se não há uma direção, um sentido transcendente para o cosmos e a história, o que existe é o fluxo. "Tudo é fogo"75, diria Heráclito, o filósofo "trágico" por excelência. Tudo está em constante transformação e "não se pode entrar duas vezes no mesmo rio" ". Não há um sentido único, nem o bem e o mal no fluxo, no devir, pois “Tempo é criança brincando, jogando pedrinhas: o reinado da criança". ${ }^{77}$ Quer dizer, o universo e a vida são vistos como um jogo que é jogado com inocência. As transformações provêm da luta de contrários, a cada nova jogada. O “ponto de vista trágico" resgatará essas características cosmológicas e terá como uma constante a ausência de um plano divino único com um sentido especial para o homem a reger o cosmo. Não

\footnotetext{
${ }^{74}$ Para Castoriadis, isto quer dizer que não há esperança em um Deus protetor e benevolente, e, portanto, trata-se "de agir e pensar neste mundo". CASTORIADIS, 2002, p. 301.

${ }^{75}$ Heráclito, fragmento 90.

${ }^{76}$ Heráclito, fragmento 49.

${ }^{77}$ Heráclito, fragmento 52.
} 
há um telos a ser atingido fora do jogo da necessidade. Essa caracterização do cosmos não leva necessariamente a uma visão triste da vida, nem tem que ser uma visão "elitista" ou desmobilizadora ${ }^{78}$

\section{Limites do conhecimento humano e "pluralismo"}

\section{"CORO:}

Aos mortais é possível conhecer diversas coisas com a vista. Mas, do seu porvir, ninguém é adivinho". Sófocles, Ájax, 1420

“CORO (...)

Sabença não é sabedoria, pensar-se não mortal.

Breve a vida.

Quem visa o deslimite, perde o dia presente. Só louco assim procede, ou - julgo um malevolente". (Eurípides, As Bacantes, 395-402)

Para os antigos, as súbitas manifestações do Caos seriam pouco previsíveis, mesmo a vontade dos deuses, aos quais se apelava em diversas situações, não seria plenamente previsível, os adivinhos eram falíveis, e havia disputas entre os próprios deuses, o que limitaria qualquer pretensão humana de um conhecimento exato. A pretensão de um pleno conhecimento e domínio da realidade seria, para os trágicos gregos, a manifestação de um tipo de hybris: a arrogância. "Sabença não é sabedoria", diz o Coro das Bacantes, "quem visa o deslimite perde o dia presente" e "só um louco assim procede", continua o Coro, em mais uma manifestação de que o trágico não representa uma defesa do excesso, da hybris, mas antes o contrário, são as pretensões do racionalismo de Platão que representavam um excesso. Não podemos ter certeza quanto a

\footnotetext{
78 'Nietzsche 'Dionysian pessimism' is the source of his most radical claims, claims that have, most recently, appealed to a series of radically democratic political theorists (...) Nietzsche's pessimism does not require elitism, and does not recomend passivity (...) It makes little sense, therefore, to link pessimism (or pessimism-cum-tragedy) with conservative politics. The pessimistic spirit is a restless one, unlikely to be enamored of the status quo". Dienstag, Joshua Foa. Tragedy, Pessimism, Nietzsche. In: Rethinking Tragedy (ed. by Rita Felski). John Hopkins University Press, 2008, p. 116.
} 
Sócrates, entretanto, a frase délfica citada por Sócrates, "Conhece-te a ti mesmo", que alguns modernos erroneamente interpretaram como um apelo à autoconsciência, um apelo a que busquemos em nós mesmos a verdade, tinha um significado diferente, referia-se à consciência dos nossos próprios limites, a consciência dos limites do conhecimento humano, posição que será constante no ponto de vista trágico ${ }^{79}$.

Sem um criador com um plano para o mundo e para o homem a questão da finalidade permanece em aberto. Não há uma única finalidade, mas múltiplas possibilidades. Por esse motivo, alguns "trágicos modernos", como Deleuze, sustentam o "pluralismo", no sentido de “politeísmo de valores", como uma das características do trágico: "a afirmação múltipla ou pluralista da existência é a essência do trágico". ${ }^{80}$ A visão trágica seria essencialmente “pluralista", pois não crê em uma verdade única, mas afirma que elas são múltiplas ${ }^{81}$. Assim como são múltiplos os deuses. Não existia a pretensão de que todos os homens seguissem uma única religião, entendiam os pagãos que cada povo tinha seus deuses, cada família seu próprio culto doméstico, e no culto a Dionísio, por exemplo, a escolha de participar era do próprio indivíduo. Já as religiões monoteístas do livro (judaísmo, cristianismo e islamismo), por acreditarem na existência de um único Deus, cuja vontade estaria expressa em um livro revelado

\footnotetext{
${ }^{79} \mathrm{~A}$ ideia de limite parece ser um traço do racionalismo moral, e não do trágico, este pode parecer a alguns uma defesa da hybris e um desprezo pela ideia de limite, entretanto, vimos que, mesmo para Nietzsche, o trágico representava um equilíbrio e o racionalismo é que era considerado por ele uma hybris. Na leitura das peças dos poetas trágicos antigos não há tanto espaço para estas interpretações equivocadas que foram feitas a respeito do trágico nietzscheano.

${ }^{80}$ Deleuze, G. Nietzsche e a filosofia. Ed. Res, 2001, Portugal. Cap. 1: O trágico. p. 28.

${ }^{81}$ Eagleton relaciona essa posição que chamamos de "trágica" com Max Weber e Isaiah Berlin: "The price of freedom, then, is an incompatibility of persons or goods; and to this extent tragedy would seem built into a pluralist or individualist culture. Indeed, into some non-pluralist cultures too, since Aristotle in the Ethics also sees goods as incommensurable. You can avoid collisions of competing goods only by suppressing the specificity of value, proposing some common yardstick or exchange value by which different kinds of excellence can be compared. But it is hard to see how you can weigh courage against patience, any more than you can balance duck soup against double glazing. Max Weber maintains that there are some fundamental, intractable conflicts of value which must simply be soberly confronted: 'the ultimately possible attitudes to life are irreconcilable, and hence their struggle can never be brought to a final conclusion'. (...) Perhaps the most renowned exponent of this quasitragic moral theory is Isaiah Berlin, who maintains that 'the world that we encounter in ordinary experience is one in which we are faced by choices equally absolute, the realization of some of which must inevitably mean the sacrifice of others'. There is no single formula to harmonize the diverse ends of humanity, and tragedy in Berlin's view can thus never be entirely eliminated" Grifos nossos. (EAGLETON, 2003, p. 229)
} 
diretamente por ele, teriam uma tendência ao dogmatismo e ao proselitismo, que, em determinados contextos, poderia levar à intolerância e à guerra civil religiosa. Como se sabe, o próprio conceito de tolerância é moderno, pois surgiu como resposta à opressão religiosa e aos conflitos civis religiosos, que ocorreram nas monarquias absolutistas da Idade Moderna. Entre os politeístas antigos, a guerra era por terra, pelo butim ou pela glória, não para eliminar ou converter os infiéis.

O monoteísmo do livro levaria a um fechamento dogmático do sentido, pois a Verdade já estaria revelada. Isso tenderia a produzir desinteresse por certas áreas do conhecimento. Momigliano observa que os judeus foram grandes historiadores antes da Torá estar sistematizada. Depois, perdem o interesse pela historiografia ${ }^{82}$. Os historiadores gregos, por sua vez, permaneceram interessados pela pesquisa histórica e "escreveram a história como um povo livre", demonstrando frequentemente uma "atitude crítica" com relação ao registro dos acontecimentos (MOMIGLIANO, 2004, p. 54). O politeísmo, sem livro revelado e sem classe sacerdotal com monopólio interpretativo, não fecha a questão do sentido. Nem mesmo o sentido histórico está resolvido. Para Momigliano, a ideia de que todos os historiadores antigos pensavam a história como sendo cíclica é falsa e uma invenção moderna ${ }^{83}$. A historiografia antiga, segundo Momigliano, não parece endossar a ideia de ciclo. Apenas em Políbio, quando trata sucessão das constituições, há a ideia de um encadeamento lógico de tipo cíclico, entretanto, o próprio Políbio não adota a ideia de ciclo quando trata de temas menos abstratos, como guerras e acontecimentos políticos importantes ${ }^{84}$.

82 "Por um lado, os judeus que vieram depois da bíblia pensavam que este livro continha toda a história que
realmente importava: a supervalorização de um certo tipo de história implicava em uma subvalorização de todos os
demais eventos. Por outro lado, todo o desenvolvimento do judaísmo conduziu a algo que não era histórico, que era
eterno, a Lei, a Torá. O sentido que os judeus acabaram dando à Torá, matou o seu interesse por uma historiografia
mais geral. 'não há na Torá nem mais cedo nem mais tarde' (Pes. 6b). Com efeito, como todos sabemos, 'Deus, ele
mesmo, senta-se e estuda a Torá'. A familiarização com o Eterno não requer nem admite a explicação histórica."
MOMIGLIANO, 2004, p. 44 .
83 "Não há qualquer indicação nos historiadores gregos de que acreditassem em uma recorrência inevitável e regular
dos acontecimentos. A noção muitas vezes repetida de que os historiadores gregos tinham uma ideia cíclica do
tempo é uma invenção moderna". MOMIGLIANO, 2004, p. 38 .
${ }^{84}$ A ideia de ciclo nem sempre aparecia entre os antigos como um ciclo de retorno lógico e idêntico de todas as 
Castoriadis também destacou a abertura dos gregos em relação ao sentido, que teria tornado possível "a descoberta do abismo" (CASTORIADIS, 2004). Todas as sociedades tentariam encobrir o "abismo" construindo uma explicação "tradicional" a respeito da origem do mundo, do cosmos, dos deuses e do homem, das instituições da cidade e explicações sobre a morte. A explicação tradicional da "tribo" visaria ocultar esse abismo. Mas, segundo Castoriadis, “a peculiaridade da Grécia é o reconhecimento de que a opinião da própria tribo nada garante: ela é apenas seu 'nomos', sua lei estabelecida, sua 'convenção'” (CASTORIADIS, 2004). Para Castoriadis, todos os povos se interrogaram sobre o "abismo", mas esse espaço da interrogação é fechado tão logo se abre. Na religião judaico-cristã, diz Castoriadis, “o Abismo falou, ele nos falou - portanto, não é mais um abismo (os cristãos continuam a pensar assim)”, já na Grécia, a “interrogação não permanece simples interrogação, mas se torna afirmação interrogante, isto é, atividade de transformação da instituição" (CASTORIADIS, 2004).

O "pluralismo" a que nos referimos significa que na época politeísta dos trágicos não havia a crença em uma verdade única e universal. Nesse sentido, os sofistas também estariam seguindo a tradição trágica, mas em uma versão laicizada, já em outro momento do desenvolvimento da vida social grega, diferente do momento da epopeia. A conhecida frase do sofista Protágoras expressa bem essa posição trágica a respeito das "verdades” morais: “O homem é a medida de todas as coisas". A frase indica uma espécie de "humanismo trágico" que coloca o homem no centro, o vê como um problema e entende a verdade na chave do perspectivismo. A mudança na visão grega tradicional sobre a verdade e sobre o lugar do homem coisas. Seu sentido mais comum era aquele inspirado na observação da natureza com todos os seus seres tendo um ciclo de nascimento, crescimento, maturidade e morte. Esse "naturalismo" era reforçado pelo fato de que a religião pagã não era teleológica, e, sem finalidade, o que resta é a transformação constante, é o ciclo natural. Skinner observou que essa concepção ressurge no renascimento (SKINNER, 2000, p. 131). Segundo Pocock: "The Greek and Roman intellects saw little reason to expect anything very new to happen in the human future, and doctrines of cyclical recurrence or the supremacy of chance (tyche or fortuna) arose and interpenetrated - though we must beware of exaggerating or simplifying their importance - to express this lack of expectation (...) The advent of the savior monotheisms, however, reorganized and transformed time by making it an aspect of events whose significance was in eternity (POCOCK, 1975, p. 31). Sobre a ideia de ciclo em Políbio: "To Polybius the cycle was a physis, a natural cycle of birth, growth, and death through which republics were bound to pass" (POCOCK, 1975, p. 77) 
tem início com a filosofia de Platão, o grande crítico dos trágicos e dos sofistas. Na filosofia de Platão, o homem não está mais no centro, e o que ocupa o seu lugar é:

“O ser, ou Deus. Na época trágica, Protágoras dizia: 'o homem é a medida de todas as coisas'. Platão responde: 'Protágoras está enganado, Deus é a medida de todas as coisas e do homem'. Para os sofistas, o homem é um fazedor de discursos e a todo discurso pode-se opor o discurso contrário. Não existe verdade. Na tragédia, personagens trocam discursos opostos. Mas Platão vai dizer: "Não. Se existem dois discursos, um é verdadeiro, o outro é falso'. De um lado temos o século trágico e problemático, do qual a sofística é um dos aspectos; de outro, uma recusa conjunta da tragédia, da sofística e do mundo da aparência, e a afirmação de que existe uma verdade, que o homem não está no centro, que o que está no centro é o ser, o Bem, Deus” (VERNANT, 1996, p. 356)

\title{
Politeísmo, conflito e agonismo
}

\begin{abstract}
"A sabedoria de Chréo diz que Pólemos é de todos, que Dike é Éris. Que tudo nasce de Éris e de Chréo são filhos.”

(Heráclito, fragmento 80)

"Se a mesma coisa fosse para todos igualmente bela e sábia, os humanos não conheceriam as controvérsias das querelas. Mas para os mortais nada há de semelhante, nem de igual, salvo nas palavras; a realidade é toda diferente". (Eurípides. As Fenícias, 499)
\end{abstract}

$\mathrm{Na}$ cultura pagã greco-romana, o universo era visto como sendo eminentemente conflitual. Os múltiplos deuses, verdades e homens estão em disputa. Como disse Heráclito, tudo nasce da luta (Éris), a luta é a mãe de todas as coisas ${ }^{85}$ e na luta de contrários existe "a mais bela harmonia" ${ }^{86}$ Em Homero e em Hesíodo, a disputa entre contrários está sempre presente no centro de sua obras. O mesmo ocorre nas comédias de Aristófanes e nas peças trágicas de Ésquilo, Sófocles e Eurípides. A pluralidade radical das "verdades" provoca as "querelas", no dizer de Eurípides acima citado. A ausência de um fundamento absoluto, revelado e claro sobre o "bem"

\footnotetext{
85 "De todas as coisas a guerra é pai, de todas as coisas é senhor; a uns mostrou deuses, a outros, homens; de uns fez escravos, de outros, livres". Heráclito, fragmento, 53.

${ }^{86}$ Heráclito, fragmento 8 .
} 
gera intensos dilemas, e angústia, pois o indivíduo é frequentemente colocado diante de uma situação de escolha entre diferentes opções válidas.

Quando dizemos “diferentes opções válidas" queremos dizer que o que é típico do conflito trágico não é a luta entre o bem e o mal ${ }^{87}$. Algo que Aristóteles já havia notado quando afirmou que o personagem trágico não poderia ser nem muito bom nem muito $\mathrm{mau}^{88} \mathrm{e}$ criticou Eurípides por ter tornado o rei Menelau excessivamente malvado em sua peça Orestes. Para Aristóteles, o infortúnio do herói não é o resultado de uma falha moral, portanto, não é um castigo por um pecado ou qualquer castigo no sentido moral. O infortúnio do herói provém de um erro (hamartia), mas um erro entendido em sentido não moral. O herói errou em seus cálculos, ou foi enganado por algum deus, ou estava cego pelos seus próprios impulsos e paixões, sobre os quais ele não tinha, verdadeiramente, escolha. Assim, não há uma condenação moral categórica, até mesmo porque não há propriamente uma moral categórica, mas sempre juízos éticos condicionados, "prudenciais", para fazer referência ao conceito de phronesis de Aristóteles, e pensá-lo em oposição ao imperativo categórico kantiano. Esse caráter sempre condicionado dos juízos éticos, sem entrar na discussão da Ética de Aristóteles, aparece na Poética, quando Aristóteles comenta como se deve julgar um personagem. ${ }^{89}$

Como procuramos mostrar no primeiro capítulo, Goethe e Hegel desenvolveram este ponto e consideraram o conflito entre o bem e o bem, entre direito e direito, como típico das tragédias. É curioso que uma das consequências desta ausência de maniqueismo seja que o

\footnotetext{
${ }^{87}$ Para Kaufmann, este maniqueismo só foi introduzido nas tragédias a partir da influência cristã: "once Christian influences had replaced the impact of the Iliad, evil characters did appear in tragedy". KAUFMANN, 1992, p. 141.

88 "Resta o herói em uma situação intermediária; é aquele que nem sobreleva pela virtude e justiça, nem cai no infortúnio em consequência de vício e maldade, senão de algum erro (hamartia)". ARISTÓTELES, 2005 , p. 32.

89 "Para examinar se alguma personagem disse ou fez alguma coisa bem ou não, devemos não só considerar se é nobre ou vil em si o ato ou a palavra, mas também levar em conta a personagem que age ou fala, a quem o faz, quando, por quem ou para que; por exemplo, a fim de deparar um benefício maior, ou prevenir maior malefício". Grifos nossos. Aristóteles. Poética. Em: A Poética Clássica. Tradução Prof. Jaime Bruna. Ed. Cultrix, 2005 , p. 49. Obs. Uma moral categórica como a kantiana não opera esse tipo de cálculo "prudencial" entre meios e fins que é capaz de aceitar uma ação má como meio para deparar um benefício maior ou prevenir maior malefício. $\mathrm{Na}$ moral categórica não pode haver contradição entre moralidade e utilidade e não se pode mentir nem mesmo "por amor à humanidade", como defendeu Kant. Quer dizer, do ponto de vista da moral categórica, os atos de um personagem devem ser julgados “em si”, e não da maneira sempre condicionada descrita por Aristóteles na Poética.
} 
ponto de vista trágico possui um tipo de "humanismo trágico", que aparece, por exemplo, na maneira como os inimigos eram retratados. Os inimigos eram vistos simplesmente como adversários, não necessariamente como "inimigos maus", infiéis ou depravados. Não eram a encarnação do mal. O modo como os inimigos troianos aparecem na Ilíada é bastante ilustrativo. Apesar de ser inimigo, o troiano Heitor é apresentado como tendo mais virtude que o grego Agamenon. ${ }^{90}$ Os gregos venceram, e queriam vencer de todas as formas, mas não deixam de observar as qualidades do adversário, nem mesmo de sentir compaixão pelo drama dos derrotados. Esta maneira de retratar os inimigos, semelhante ao modo como adversários são retratados em um jogo esportivo, é comum na literatura grega, seja nos poemas épicos ou nas peças trágicas. A ausência de maniqueismo faz com que o conflito entre dois heróis ou dois povos valorosos seja realmente trágico, pois os dois não podem vencer. Apenas um prevalecerá, como em um jogo. Quer dizer, não há ganho sem perda. Quando existe o bem e o mal, não há intensidade trágica nem angústia na escolha: basta escolher o lado do "bem" e combater o "mal". No confronto do bem contra o bem, além da intensidade trágica ser maior, também há espaço para o reconhecimento das qualidades do adversário, como aparece no belo diálogo entre Agamêmnon e Ulisses, na peça Ajax, de Sófocles, quando Ulisses insiste em dar enterro digno a Ájax, que pouco antes havia tentado matá-lo:

"AGAMÊMNON - Recorda a quem concedes teu favor.

ULISSES - Inimigo, mas tinha fibra nobre.

AGAMÊMNON - Louvas tanto um cadáver inimigo?

ULISSES - Virtude conta mais que a inimizade.”

Sófocles. Ájax. 1355-58.

Entretanto, como observou Kaufmann, reconhecer as qualidades do adversário e sentir compaixão por ele não leva os trágicos a uma projeção de um mundo sem conflitos. O conflito é

\footnotetext{
${ }^{90}$ Procedimento semelhante encontramos na primeira tragédia grega encenada cujo texto foi preservado, "Os Persas", de Ésquilo, escrita em 472 a.C., que narra a guerra contra os persas do ponto de vista dos persas, que foram vencidos pelos gregos. Ver: ROMILLY, 1970, p. 57.
} 
visto não apenas como inevitável, mas como criador, como necessário ao desenvolvimento da vida. Na tragédia grega, diz Kaufmann, a rivalidade entre "cavaleiros” foi sublimada em uma visão da vida. ${ }^{91}$

Como se sabe, a valorização do conflito/disputa, ou o agonismo, era uma das características centrais da cultura grega. A palavra grega Ágon refere-se a luta, competição, disputa, discussão. Inicialmente utilizada para se referir a luta de arena, o Ágon aparece com frequência na literatura grega (na épica, na comédia e na tragédia) na forma de disputa entre personagens no centro da trama, ou na forma de disputa entre raciocínios opostos. ${ }^{92}$ Um episódio que expressa bem o caráter agonístico da cultura grega, é o encontro entre Anacharsis ${ }^{93}$ e Sólon, narrado por Luciano ${ }^{94}$. Estranhando a luta na arena, Anacharsis pergunta a Sólon: "Por que seus jovens fazem tudo isto? Alguns de seus jovens estão agarrados uns aos outros se batendo mutuamente, enquanto outros rolam unidos na lama, remexendo-se, rebolando como porcos". Anacharsis, educado em outra cultura, enxergava nessas lutas a futura hostilidade entre os cidadãos. O que o deixava ainda mais espantado era o fato de que os lutadores não recebiam grandes recompensas, mas apenas coroas de louros, maçãs, azeite de oliva. Sólon lhe responde dizendo que a luta era boa em si mesma e em suas consequências e que os prêmios significavam a glória diante da multidão. Anacharsis também expressou seu espanto diante de outro gênero de disputa em Atenas: a disputa política na assembleia do povo. Anacharsis afirmou, ao frequentar as assembleias políticas atenienses, que "na assembleia os sábios falam, mas os tolos decidem"

\footnotetext{
91 "In Greek tragedy chivarly has been sublimated into a view of life: not only was there once a war in the remote past between worthy opponents, but in man's conflicts with man there is typically some humanity and some right on both sides". KAUFMANN, 1992, p. 140.

92 "Nascido do hábito do debate judicial, aperfeiçoado pela retórica da época, a arte da discussão oratória estava então em pleno desenvolvimento. Era aquilo a que se chamava agôn. Ora, não há quase nenhuma tragédia de Eurípides que não tenha pelo menos uma cena de agôn. No agôn, cada um defendia seu ponto de vista com toda a força retórica possível, num grande desdobramento de argumentos que, naturalmente, contribuíam para esclarecer o seu pensamento ou a sua paixão". ROMILLY, 1970, p. 41.

${ }^{93}$ Anacharsis foi um pensador do povo Scita, povo que vivia ao norte da Grécia nas bordas do Mar Negro. Anacharsis viajou para a Grécia no início do séc. VI a.C. Em suas viagens, Anacharsis causou forte impressão como um "bárbaro" culto e seus diálogos com pensadores gregos se tornaram célebres e influenciaram algumas tendências do pensamento grego, como o ceticismo e o cinismo.

${ }^{94}$ François Hartog comenta o episódio em: HARTOG, 2004, p. 130.
} 
(PLUTARCO, 1952, p. 66). Se para o cita a disputa era algo que não fazia sentido, para o grego, a disputa era "boa em si mesma", necessária para manter em exercício a virtude e promover a saúde dos cidadãos e da cidade.

É certo que havia variações em relação a qual tipo de disputa possuía maior valor, o que era considerado uma disputa boa ou ruim e qual era a medida da disputa, entretanto, não havia uma crítica à disputa em si. O camponês Hesíodo, em Os trabalhos e os dias, por exemplo, não destacava tanto o gênero de disputa entre heróis na guerra, mas a disputa/luta econômica por meio do trabalho, que ele distinguia da disputa "funesta":

"Não há origem única de Lutas, mas sobre a terra

duas são! Uma louvaria quem a compreendesse,

condenável a outra é; em ânimo diferem ambas.

Pois uma é guerra má e o combate amplia,

funesta! Nenhum mortal a preza, mas por necessidade,

pelos desígnios dos imortais, honram a grave Luta.

A outra nasceu primeira da Noite Tenebrosa

e a pôs o Cronida altirregente no éter,

nas raízes da terra e para os homens ela é o melhor.

Esta desperta até o indolente para o trabalho:

pois sente um desejo de trabalho tendo visto

o outro rico apressado em plantar, semear e a

casa beneficiar; o vizinho inveja ao vizinho apressado

o oleiro ao oleiro cobiça, o carpinteiro ao carpinteiro,

o mendigo ao mendigo inveja e o aedo ao aedo.” (HESÍODO, 1996, p. 23)

Este gênero de disputa valorizado por Hesíodo coloca a inveja como positiva por “despertar até o indolente para o trabalho", numa espécie de antecipação de futuras formas de valorização da disputa. O camponês Hesíodo não vivia a disputa política, nem a disputa heroica 
na guerra, nem menciona a disputa esportiva, restava-lhe a disputa no trabalho. A disputa parecia aos helenos insuperável, quando apertada de um lado, desenvolvia-se em outro, restava, portanto, fornecer medida à disputa, e o fizeram por meio do agonismo, em que a vontade era excitada, e, ao mesmo limitada por outra vontade. A imagem dessa forma agonística de dar medida à disputa e à vontade é a arena, que está mais na perspectiva do jogo, do duelo, do que da dominação total ou da disputa funesta. Os textos gregos fornecem indicações de que o grego "não podia carregar a fama sem a continuação da disputa, nem a felicidade no final da disputa" (NIETZSCHE, 1872a, p. 75). Essa maneira de fornecer medida será característica do ponto de vista trágico.

\section{Naturalismo e Vontade}

Para o paganismo antigo, os elementos primordiais, o mundo, os deuses e os homens não são criados por um deus transcendente e com um plano: eles surgem naturalmente e sem um plano. Nesse sentido, em contraste com a ideia de criação, a cosmologia pagã era naturalista e os próprios deuses tinham a sua moira, o seu destino, em vez de possuírem uma vontade totalmente "livre" que ordenasse seu destino e o mundo. O mesmo encontramos nos poemas de Homero. Convém, entretanto, esclarecer que o emprego do termo naturalismo não é exato, pois não havia na época uma oposição entre natural e sobrenatural, como observou Kaufmann (KAUFMANN, 1992, p. 150), porque essa distinção depende de uma distinção entre corpo e alma. Somente quando o corpo visível não é mais considerado o meu verdadeiro eu é que o mundo visível é subordinado a outro, ao "mundo verdadeiro". Nesta visão, a verdadeira morada da alma não é neste mundo. Assim, para Kaufmann, a alma, e sua distinção em relação ao corpo, seria a fonte do sobrenatural. A imortalidade da alma não existia na religiosidade grega tradicional, foi introduzida depois e tinha sua origem no oriente. Não há distinção entre natural e sobrenatural, 
pois os deuses também estão presentes neste mundo ${ }^{95}$ e não há um ponto de apoio fora deste mundo que permita a existência daquilo que, a partir da cristandade, se chamou de uma vontade livre. Quer dizer, para os trágicos, não há uma alma racional que possa ter livre-arbítrio sobre o corpo. Nessa perspectiva, o autocontrole não partiria de um eu racional capaz de submeter os impulsos, mas de um equilíbrio imanente entre impulsos, uma hierarquia entre impulsos, ao mesmo tempo de origem natural e orientada pelos costumes e hábitos.

Vê-se, portanto, que a concepção de indivíduo e de vontade na época dos trágicos era bem diferente da concepção moderna. Para intérpretes ainda vinculados de alguma forma ao projeto iluminista, como Vernant, os gregos ainda não haviam chegado às categorias modernas de vontade e indivíduo. Para trágicos modernos, como Nietzsche, Foucault, Maffesoli, entre outros, os trágicos gregos eram anteriores à ilusão do sujeito livre, ancorada na filosofia metafísica e nos pressupostos da religião judaico-cristã. Para tomarmos a imagem de Maffesoli, os trágicos gregos eram anteriores ao "parênteses moderno", no eclipse da modernidade, as noções modernas de vontade e de indivíduo passariam a ser questionadas e os trágicos voltariam a ter atualidade.

Para Vernant, embora não tivessem chegado à concepção moderna, os gregos já conheciam a individualidade sob diversas formas. Haveria três maneiras de detectar a presença do indivíduo na Grécia (VERNANT, 1992, p. 322). A primeira delas seria o indivíduo valorizado como tal, forma que já aparece nos poemas épicos e está vinculada à valorização da singularidade do herói. A segunda forma seria o domínio do indivíduo sobre sua vida privada. A terceira forma seria a emergência do indivíduo dentro das instituições sociais que, em seu próprio funcionamento, forneciam a ele um lugar central do período clássico em diante, especialmente nas instituições religiosas e no direito. Segundo Vernant, a literatura grega teria

\footnotetext{
95 "Compared to the God of the biblical Creation story, Homer's gods are not supernatural but part of nature (...). By contrast, Homer's gods are in the world; nature is full of divine beings that deserve worship. Kaufmann, Walter. Tragedy and Philosophy. Princeton University Press, 1992, p. 152.
} 
expressado esse desenvolvimento do indivíduo também nas biografias e autobiografias. Ainda assim, os antigos não chegaram a desenvolver a forma moderna do diário, que expõe de forma mais detalhada a vida interior do indivíduo. Para Vernant, na Grécia “o ego não era delimitado nem unificado, era um campo aberto de múltiplas forças" (VERNANT, 1992, p. 328). Sua experiência estava voltada para fora e não para dentro. Os indivíduos procuravam e encontravam a si mesmos nos outros, como espelhos refletindo suas imagens. Os pais, crianças, amigos eram como alter-egos de cada um. O indivíduo era projetado e objetivado naquilo que ele realizava. A consciência não era reflexiva, fundada em si mesma, embora já houvesse indícios desse desenvolvimento na poesia lírica. Entretanto, para Vernant, em geral a consciência grega não era interna, face a face consigo mesma: era existencial. Para os gregos, a existência seria anterior à consciência. ${ }^{96}$ Para Vernant, o "penso, logo existo" não teria significado para um grego (VERNANT, 1992, p. 328).

Segundo Vernant, é somente nos séculos III e IV da era cristã que começa a se desenvolver uma nova concepção de pessoa a partir das "relações com o divino na experiência de si de cada um". Esse processo estaria relacionado com a ascensão do religioso ascético cristão que se separa da horda comum em busca de seu eu verdadeiro. Para Vernant, a busca de Deus e a busca do self são duas dimensões do mesmo transe solitário. Nasceria aí uma nova forma de identidade que "define o indivíduo pelos seus pensamentos mais íntimos, suas imaginações mais secretas, seus sonhos noturnos, seus caminhos pecaminosos, e uma presença obsessiva e constante de todas as formas de tentação em seu coração”. Esta ruptura com o passado pagão seria o "ponto de partida do self moderno" e da noção de livre-arbítrio (VERNANT, 1992, p. $332)^{97}$. Somente a partir desse ponto de partida é que se poderia falar em vontade no sentido

\footnotetext{
${ }^{96}$ Muitos comentadores notaram afinidades entre o "trágico" e a filosofia existencialista do século XX. "The french writers Albert Camus and Jean Paul Sartre developed some of the ideas in Kierkgaard's and Nietzsche's philosophy to formulate an existential vision of life with tragic overtones". WALLACE, 2009, p. 131. Ver também: KAUFMANN, 1992, p. 160.

${ }^{97}$ De outro ponto de vista, Nietzsche entendeu esse mesmo processo como surgimento da má consciência, como procuramos mostrar no primeiro capítulo.
} 
moderno.

Segundo Vernant, não havia nenhuma palavra grega que correspondesse à nossa palavra "vontade" e esta categoria moderna pressupõe não apenas uma orientação da pessoa em direção da ação, mas uma preeminência que se atribui ao agente na ação. Na concepção moderna de vontade, o agente, em suas relações com os outros e com a natureza, seria um verdadeiro centro de decisão. Através da escolha, o indivíduo se constituiria como agente responsável e autônomo. Na tradição grega antiga, não há "vontade" nesse sentido racionalista nem no homem, nem no cosmos, pois este não é visto como produto de uma vontade criadora e com um plano.

Um dos obstáculos à noção racionalista de vontade entre os gregos era sua ideia "naturalista" de que certas características do "temperamento" individual eram derivadas da physis, e, portanto, não estariam sujeitas à escolha e teriam influência determinante nas ações. Na peça de Sófocles, Ájax era irascível, mas não adquiriu essa característica do meio em que foi criado. Ele simplesmente nasceu assim. Essa ideia de que as virtudes ou defeitos de uma personalidade tinham origem na physis predominava nos primeiros tempos da Grécia, e aparece na obra de poetas aristocráticos como Píndaro. Nesta concepção aristocrática, a virtude não poderia ser ensinada, pois teria origem na physis do indivíduo. Nos tempos de ascensão popular nas cidades-estado gregas, essa concepção de virtude foi questionada e surgiu a concepção de que a virtude poderia ser ensinada. Como se sabe, os Sofistas, Sócrates, Platão e Aristóteles engajaram-se na demonstração deste ponto. Entretanto, nenhum deles, mesmo reconhecendo a importância do meio e da educação na conformação da personalidade, chegou a negar totalmente a influência de fatores "naturais". Eles não chegaram à teoria moderna da "tábula rasa".

Aristóteles, por exemplo, considerado por muitos como o antigo que mais se aproximou da categoria moderna de vontade, ainda não tem nem a teoria moderna da "tábula rasa" nem a concepção de um "eu racional que escolhe livremente os fins" (SANDEL, 1992). A Phronesis 
(Prudência) aristotélica é uma virtude intelectual capaz de medir, calcular, avaliar, a melhor opção a ser escolhida em uma determinada situação. A prudência ajudaria a encontrar os meios necessários para se atingir um fim, mas os fins não seriam, eles próprios, passíveis de escolha, pois são da ordem do desejo e tem origem natural ou são criados pelo hábito. Daí vem a conclusão de Aristóteles de que nós não deliberamos sobre os fins, mas apenas sobre os meios ${ }^{98}$. Eagleton também enfatiza que em Aristóteles não há um confronto entre "liberdade" e "necessidade", mas entre necessidades internas e externas, as internas derivariam de nosso temperamento, fruto da physis e da educação, portanto, não haveria em Aristóteles aquela noção forte de "autonomia" exigida por uma boa parte dos modernos ${ }^{99}$.

Do ponto de vista da noção moderna mais forte e racionalista de vontade, os gregos não conheciam a autonomia, suas ações seriam consideradas sempre heterônomas, pois as finalidades das ações não eram passíveis de escolha, toda ação era entendida como transcorrendo em meio a constrangimentos e o agente é movido tanto por causas externas (destino, deuses, acaso sem sentido) quanto por causas internas (seu caráter, derivado da sua physis e dos costumes).

\section{A gaia liberdade e o enfrentamento com o destino}

Diante disso, o que seria liberdade do ponto de vista trágico? Será pensada no plano terreno (gaia), sem nenhum apoio exterior ao jogo da necessidade. Ao contrário, a liberdade trágica implica, em certo sentido, afirmar a necessidade. Para o indivíduo, por exemplo, seria “tornar-se aquilo que ele é” (Píndaro), ceder ao que lhe é espontâneo, natural, o que envolve uma

\footnotetext{
${ }^{98}$ ZINGANO, 2007, pp. 226-227. Ver também: VERNANT, J.P. e NAQUET, P.V., 1981, p. 32. Entre os trechos da Ética citados para defender esta posição costuma-se citar: "o fim é, pois, objeto de desejo e os meios, objeto de deliberação e decisão" (Ética a Nicômacos, 1111 b26) e "O princípio da decisão é o desejo e o cálculo o que calcula os meios de obter um fim" (Ética a Nicômacos, 1139 a31).

99 "Aristotle seems to contrast not freedom and necessity, but inner and outer necessities. There is a dash of psychological determinism about his thought. Indeed, if the hamartia or moral flaw which supposedly causes tragedy is built into our temperament, and is less sin than innocent error, how can we be held responsible for it? Necessity is not always outside us: there is one's daimon or bent of character, which for both Goethe and Lessing had all the force of destiny. An 'authentic' action is one which springs from the core of the self; but you might therefore quite as well call it irresistible as call it free" (EAGLETON, 2003, p. 118).
} 
estilização da sua natureza, preenchimentos de conteúdo diverso e leque de possibilidades existenciais, mas não uma negação absoluta da natureza e leque infinito de possibilidades, para os trágicos algo no fundo impossível. Por outro lado, a liberdade se realiza na ação, e esta é sempre um salto no escuro, pois o conhecimento do agente nas ações é sempre limitado e as consequências de seus atos escapam ao seu controle, características que são centrais nas peças trágicas. Além disso, a ação frequentemente ocorre em um meio conflitivo.

Entretanto, essas dificuldades não levam a uma rejeição da vida, do mundo e nem da ação. Pelo contrário, a ação é o meio por excelência para a afirmação da liberdade. Na ação, o indivíduo afirma sua natureza e seu valor. Na epopeia e nas tragédias gregas, o herói enfrenta o seu destino com coragem, e, ainda que venha a ser destruído, cai com dignidade e a sua performance lhe permite conquistar o reconhecimento imortal, o troféu de sua virtude. A performance permite ao indivíduo conquistar o seu mais alto objetivo: "honra, glória e fama". Objetivo absolutamente mundano, que passará a ser condenado pelo cristianismo como manifestação do primeiro pecado capital (Orgulho/Vaidade), mas que, para um grego e romano antigo, seria uma maneira de tentar prolongar seu nome em meio ao fluxo da necessidade e do tempo, quer dizer, uma maneira de se imortalizar ${ }^{100}$.

Ao mesmo tempo, a queda do herói não provoca uma objeção aos seus feitos, encontrando-se até mesmo prazer na dissolução, como na fala de Jocasta, antes citada, quando ela diz que "O medo em tempo algum é proveitoso ao homem", pois "O acaso cego é seu senhor inevitável" e o homem "não tem sequer pressentimento claro de coisa alguma", por isso "é mais sensato abandonarmo-nos" (SÓFOCLES. Édipo Rei, 1165). Quando tem-se a ideia de que diante do "acaso cego" e do inevitável é mais sensato "abandonarmo-nos", mas, ao mesmo tempo, há uma admiração pela ação, iniciativa, grandes feitos, o critério para a avaliação das ações não será

\footnotetext{
${ }^{100}$ Segundo Skinner, também seria assim para Maquiavel: “a conquista da honra e da glória mundanas constitui o mais alto objetivo para Maquiavel, tal como para Tito Lívio ou Cícero” (SKINNER, 1981, p. 52).
} 
exclusivamente "utilitário". Pois pode-se escolher a ação correta do ponto de vista prudencial que visa um resultado e ainda assim a ação pode fracassar, pois Tyché ou Fortuna poderiam estar contra o agente, ou o "acaso cego", como na fala de Jocasta. Nessa visão, importa mais saber se a ação foi grande e bela e se visava ao bem da polis (este aspecto especialmente a partir do período arcaico, posterior ao homérico), do que simplesmente julgá-la pelo seus resultados ou mesmo pela sua "moral"101.

É frequente nos trágicos o predomínio de juízos estéticos, sobre juízos utilitários ou morais na avaliação das ações. Para os trágicos, nem sempre o virtuoso vence, não se espere tanta justiça do cosmos. Nem sempre uma medida cuidadosamente calculada traz resultados úteis, há circunstâncias que não são conhecidas e estão fora do controle dos agentes. Frequentemente, o herói caído morre, mas ninguém vive para sempre, o importante é que sua atuação foi bela, acima da média. A despreocupação com o inevitável, com o fluxo da necessidade, a aceitação do fluxo e a entrada nele como em um jogo/brincadeira de resultado incerto para o jogador tornam-se constitutivos da liberdade trágica, a gaia liberdade. Kaufmann ressalta que em Homero a brevidade da vida não provocava uma objeção ao mundo, mas sim "um incentivo para saborear seus prazeres, para viver com entusiasmo, e morrer gloriosamente", as sombras da morte não provocavam tristeza, mas eram um "convite à alegria e à nobreza" (KAUFMANN, 1992, p. 160).

A dedicação à polis, por sua vez, não se faz sob o signo puramente altruísta, mas egoísmo e bem comum encontravam-se unidos na busca de glória, pois para alcançar a glória para si era necessário realizar grandes feitos, especialmente aqueles realizados para o bem da polis. Ao mesmo tempo, a ambição de glória era limitada pelo amor a polis e pela ambição de outros

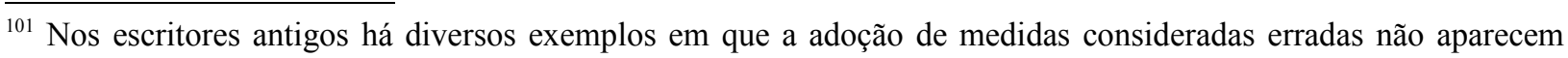
como problemáticas desde que elas fossem necessárias para o cumprimento de um papel social, como pai, guerreiro ou rei, como é frequente em Homero. Depois do século VIII a.C., com a consolidação da polis, os juízos de "necessidade" começam a vincular a aceitação de medidas "erradas" apenas para os casos em que essas medidas aparecem como necessárias para o bem da polis (ADKINS, 1975; BALL, 1984; DODDS, 1951; FINKELBERG, 1995; FINLEY, 1954)
} 
cidadãos, por meio da instituição de arenas. Conectava-se assim a pulsão para o poder dos cidadãos, sua vitalidade expansiva, com a vitalidade da polis. Uma liberdade assim concebida requeria uma pedagogia trágica que ensinaria certa dureza de caráter, de modo a tornar o cidadão capaz de suportar o fluxo e os riscos inerentes à ação e a disputa. Dureza que ensinaria também a abandonarmo-nos diante do inevitável, e, ao mesmo tempo, ensinaria a capacidade de reconhecer a virtude dos adversários e não condenar duplamente os heróis por seus erros, o que constitui uma espécie de humanismo trágico. A fraqueza é vista como negadora da liberdade, na medida em que procura negar o fluxo da necessidade, a ação e a disputa, em virtude de seus efeitos negativos, pois sob o imperativo de buscar a ausência de sofrimento definitiva procura-se negar o fluxo, a ação, a disputa e a própria política, mas isto é entendido pelos trágicos como perda de liberdade ${ }^{102}$.

A aceitação do fluxo, dos riscos da ação, da disputa e da política, são vistos pelos trágicos como uma liberação, uma afirmação da vida inteira, com suas alegrias e sofrimentos. Os obstáculos e adversários são vistos como um exercício de aprimoramento, como oportunidade para o aumento da força, quer dizer, da vitalidade. O total domínio de um só, eliminando o adversário, eliminaria a disputa, a resistência, a medida, e com isso, viriam a hybris e a decadência. Do ponto de vista trágico, portanto, a política deve ser pensada como arena para a disputa, e as instituições pensadas para manter a tensão criativa entre adversários. Apenas assim é que a política aparece aos trágicos como umbilicalmente associada à liberdade.

\footnotetext{
${ }^{102}$ Hannah Arendt, como todos os que podem ser entendidos dentro do ponto de vista trágico, também pensava a política como arena e também associa a "fuga da fragilidade dos negócios humanos" e a busca por tranquilidade como a raiz da negação da política: "A fuga da fragilidade dos negócios humanos para a solidez da tranquilidade e da ordem parece, de fato, tão recomendável que a maior parte da filosofia política, desde Platão, poderia facilmente ser interpretada como uma série de tentativas de encontrar fundamentos teóricos e meios práticos de evitar inteiramente a política”. (ARENDT, 2001, p. 234). Grifos nossos.
} 


\title{
AS TRAGÉDIAS E A CIDADE-ESTADO GREGA
}

\author{
"ÁJAX: \\ (...) Torpe é o herói que pede vida longa, \\ quando nada transmuda sua desgraça. \\ Que prazer haverá num dia após \\ outro, que afasta e desafasta a morte? \\ Nenhuma só palavra eu gastaria \\ com quem se aquece na esperança vã. \\ Um homem nobre ou vive na beleza \\ ou nela morre. É esse o meu resumo \\ CORIFEU: \\ Ninguém dirá que o teu discurso é ambíguo, \\ mas que provém do âmago de Ájax. \\ Contudo, pára. Deixa que os amigos \\ anulem teu projeto. Joga-o fora." \\ SÓFOCLES. Áax. 475-485 \\ "A tragédia é a cidade que se fez teatro, que se coloca \\ ela própria em cena, diante do conjunto dos cidadãos" \\ (VERNANT. 1981. v. 161)
}

Até agora escrevemos sobre alguns aspectos gerais da cultura grega antiga que iriam contribuir para a formação de um ponto de vista trágico. Mas não abordamos de maneira mais determinada a relação entre essa cultura grega antiga (trágica) e o contexto histórico-social em que ela surgiu, nem abordamos as diversas mudanças no interior desta cultura relacionadas às mudanças de contexto social. A epopeia e o gênero trágico devem ser entendidos como expressão de dois momentos diferentes no interior da mesma cultura e essa mudança visível na arte relaciona-se com as mudanças histórico-sociais no desenvolvimento e crise das cidades-estado.

As tragédias gregas foram encenadas em um momento bem determinado da história das cidades-estado gregas. Esse momento era muito posterior à época da epopeia homérica, que teve início com a invasão dória, destruiu o mundo micênico e deu início à um longo período de guerras. A idade homérica era anterior à consolidação da forma sócio-política das cidades-estado. Quando foram encenadas as primeiras peças trágicas, os gregos já não viviam mais nas 
sociedades heroicas dos tempos da epopeia, como destacou MacIntyre ${ }^{103}$. Entretanto, os gregos entendiam-se como herdeiros desse passado e os valores forjados nas sociedades heroicas ainda tinham forte apelo, e, como disse MacIntyre, “é das dificuldades de ligar aqueles escritos à prática real que surgem muitas das principais características morais das sociedades posteriores" (Id). Essa tensão entre os valores do passado heroico e o presente da cidade-estado democrática constitui o contexto do surgimento do gênero trágico, um contexto que, ao mesmo tempo, representa continuidade e ruptura, no interior do mesmo universo cultural. Isso porque,

“Com efeito, a epopeia e a tragédia abordam o mesmo assunto. Entre as obras conservadas todas referem-se aos mesmos mitos que a epopeia: a guerra de Troia, às façanhas de Herácles, aos infortúnios de Édipo e sua estirpe. Nas peças conservadas, apenas duas fogem aos temas antes abordados pela epopeia: uma tragédia relativa ao mito de Dionísio (As Bacantes, de Eurípides) e uma peça histórica (Os Persas, de Ésquilo)”. (ROMILLY, 1970, p. 21) ${ }^{104}$

As personagens das tragédias, assim como os da epopeia, pertenciam ao passado heroico e eram revestidas de uma certa grandeza. Segundo Romilly, a festa religiosa criou o gênero trágico, mas "foi a influência da epopeia que fez dele um gênero literário" (ROMILLY, 1970, p. 21). ${ }^{105} \mathrm{~A}$ tragédia inovou, pois representou em público estes personagens épicos, tornando pública uma emoção, uma explicação, um significado. Deste modo, desenvolveu-se uma espécie de distância, de recuo em relação ao tema, que parece ter ainda contribuído para aumentar a majestade da tragédia e para lhe conferir uma dimensão particular. Para Romilly, "a epopeia assim transposta tornou-se algo de novo. A epopeia contava, a tragédia mostrou" (ROMILLY, 1970, p. 21). Nesse sentido, a "tragédia é a cidade que se fez teatro", que se coloca em cena e se

\footnotetext{
103 "As sociedades heroicas, conforme representadas pelos poemas homéricos ou pelas sagas islandesas ou irlandesas, podem ter existido ou não; mas a crença de que haviam existido era fundamental para aquelas sociedades clássicas e cristãs que se entendiam como nascidas dos conflitos das sociedades heroicas e que definiam sua própria perspectiva parcialmente com base naquele nascimento. Nenhum ateniense do século $\mathrm{V}$ podia comportar-se exatamente como Agamenon ou Aquiles. Nenhum islandês do século XIII poderia comportar-se como os homens do século X. (...) Não obstante, a literatura era a parte fundamental dos escritos morais dessas sociedades posteriores; e é das dificuldades de ligar aqueles escritos à prática real que surgem muitas das principais características morais das sociedades posteriores". MACINTYRE, 2001, p. 225.

${ }^{104}$ Ver também: LESKY, 2006, p. 36.

${ }^{105} \mathrm{Id}$.
} 
questiona, como disse Vernant, no trecho supra citado. Quer dizer, para Vernant, a tragédia não é um mero reflexo da realidade social. A tragédia também questiona essa realidade:

"Não reflete essa realidade, questiona-a. Apresentando-a dilacerada, dividida contra ela própria, torna-a inteira problemática. $\mathrm{O}$ drama traz à cena uma antiga lenda de herói. Esse mundo lendário, para a cidade, constitui o seu passado - um passado bastante longínquo para que, entre as tradições míticas que encarna e as novas formas de pensamento jurídico e político, os contrastes se delineiem claramente, mas bastante próximo para que os conflitos de valor sejam ainda dolorosamente sentidos e a confrontação não cesse de fazer-se" (VERNANT, J.P. e NAQUET, P.V., 1981, p. 10).

Nas representações trágicas, novos temas e questões aparecem, mas a inovação se deu, como não poderia deixar de ser, sobre as crenças e valores anteriores, e algumas características centrais que vinhamos relacionando com as "fontes antigas do ponto de vista trágico" permanecem no "gênero trágico" surgido no séc. V a.C., tais como o politeísmo, ausência de teleologia, necessidade e acaso formando um "destino", conflitos irreconciliáveis entre bem e bem, limites do conhecimento humano, valorização do heroísmo como belo, mesmo se o herói tivesse um fim trágico e ou se suas ações fracassassem. No gênero trágico, o herói continuou a ser admirado, mas, ao mesmo tempo, a face problemática do heroísmo começou a ser observada. Outra novidade foi a questão da agência individual, que começa a assumir posição de destaque e até mesmo uma profundidade "interior" que não possuía na epopeia, especialmente nas peças de Eurípides. Essas mudanças no plano "cultural" estão relacionadas ao contexto social da passagem das sociedades heroicas e aristocráticas dos primeiros tempos para a emergência e consolidação da polis como forma de organização sócio-política, e, finalmente, com a transformação da polis aristocrática ateniense em polis democrática.

A civilização micênica prevalecia na Grécia nos tempos mais remotos que nos são conhecidos e era uma civilização fundamentalmente distinta daquela que inventou a polis, particularmente pela centralidade da figura do Basileu (rei) na sua organização social. Esta 
civilização micênica sofreu um grave abalo com as invasões dórias do século XII a.C., desaparecendo em seguida, o que deu origem ao período "homérico" (XII a.C. - VIII a.C.). O impacto da invasão dória foi enorme e o "período homérico" foi marcado por aquilo que Vernant chamou de "crise de soberania", que consistia na ausência de modelos alternativos de poder que se seguiu à perda de poder dos reis do mundo micênico. As guerras constantes também caracterizaram o período homérico, e estes combates eram liderados por uma aristocracia guerreira. Este é o mundo da Ilíada, o mundo das "sociedades heroicas" que formaram a ética heroica e os mitos que teriam uma influência cultural muito além de seu tempo, sendo reinterpretados em contextos posteriores. No final deste período turbulento, que foi chamado por alguns historiadores de "idade das trevas" na Grécia, começa a se consolidar uma nova forma de organização social: a polis.

Durante o século VIII a.C. este novo modelo vai se consolidando por toda a Grécia. Mas o que era a polis? Alguns chegam a dizer que não é possível defini-la, dada a variedade de polis existentes, sendo impossível agrupá-las em um único modelo. Ainda assim, arrisquemos uma breve definição de polis (cidade-estado). Para Hansen (HANSEN, 2000), as cidades-estado eram frequentemente cercadas por muros. Possuíam um centro urbano que era o centro econômico, religioso, militar e político. Parte considerável da população vivia no centro urbano. No entorno da cidade havia uma área rural com habitantes que viviam dispersos em fazendas ou concentrados em vilarejos. A população das cidades-estado na Grécia variava de 1.000 a 100.000 habitantes, com poucos casos de cidades-estado que ultrapassaram esta marca. Atenas chegou a ter mais de 200 mil habitantes, entre os quais por volta de 30.000 eram cidadãos plenos na fase democrática; Roma ultrapassou em muito essa marca. Em geral, a cidadania nas cidades-estado gregas e em Roma no início estava restrita a uma minoria de homens nobres, mas houve em diversas cidades a incorporação de mais setores na cidadania plena. Em termos de "classes" 
sociais, além dos ricos proprietários de terra, existiam homens livres não nobres que poderiam ser pequenos proprietários de terra que trabalhavam sem a ajuda de escravos, comerciantes e diversos tipos de artesãos. Também existiam homens livres sem terra, condição que muitas vezes era considerada pior que a de um escravo, por conta da incerteza vivida por quem trabalha em troca de um pagamento por serviços esporádicos e não tem uma casa e família como amparo em caso de necessidade. O escravo tinha uma casa, era um membro da família, e, portanto, sempre teria teto e comida. Embora subordinado, não era um abandonado como um sem terra livre (Tes). Os escravos variavam em número e importância dependendo da cidade-estado e os escravos, como se sabe, eram provenientes de guerras de conquista (onde os povos perdedores eram escravizados e seus descendentes já nasciam na escravidão), ou eram escravos por dívida ou escravos por terem cometido algum crime cuja pena era a escravidão. A economia de uma cidade-estado possuía uma especialização de funções e divisão do trabalho em tal medida que a população satisfazia uma boa parte de suas necessidades diárias pelas compras no mercado da cidade. Para Hansen, a Polis (cidade-estado) era um autogoverno, mas não necessariamente uma unidade política independente, pois as cidades-estado possuíam aquilo que os modernos chamam de "soberania interna", mas poderiam ao mesmo tempo pagar tributos ou ter uma relação de dependência em relação a alguma outra cidade-estado ou império, mas nada ainda tão centralizado quanto seria a moderna soberania estatal.

No período arcaico (VIII a.C. - VI a. C.) o poder político nas polis era monopolizado pela aristocracia, entretanto, já durante esse período, aparece uma das características mais típicas das cidades-estado: a stasis, o conflito social entre as diversas partes da cidade ${ }^{106}$. É por meio da stasis que a aristocracia perderá, em diversas polis, seu monopólio político, abrindo caminho para tiranias e democracias. Também é durante o período arcaico que ocorre um

106 "Classes", para marxistas como Ste Croix, ( STE CROIX, 1981). "Ordens" para weberianos como Finley (FINLEY, 1983). 
desenvolvimento inédito da "individualidade", visível nas alterações do direito, no surgimento da poesia lírica e no surgimento de uma nova forma de pensar distinta da "mitologia": a filosofia. A sociedade puramente tradicional começa a ser abalada. Esses desenvolvimentos produziram um enorme desenvolvimento artístico e intelectual, mas também teriam promovido uma relativização dos valores comuns que formavam os alicerces da "cultura" helênica, o que teria levado, segundo muitos antigos e alguns comentadores modernos a uma "corrupção dos costumes" e desmedida (hybris) de todos os tipos. A stasis e a hybris tornaram-se talvez os problemas que aparecem com mais frequência no pensamento grego, tanto nos poetas trágicos e comediógrafos, quanto na filosofia política a partir de Platão. A stasis e a hybris seriam responsáveis pela crise da cidade-estado. Por que a stasis e a hybris adquiriram tamanha importância e centralidade? Levantamos a hipótese de que essas problemas eram mais graves nas cidades-estado do que nos Impérios e no Estado moderno em virtude da ausência daquilo que Araújo chamou de "modo estatista de governar", já que as cidades-estado organizavam-se na forma de "República" (ARAÚJO, 2004).

Para Araújo, as cidades-estado antigas, na Grécia e em Roma, eram organizadas na forma de "República", já o termo "Estado" está reservado ao Estado moderno. Como características centrais da forma "República", Araújo identifica a "constituição mista" e uma ausência de marcada divisão entre civitas (conjunto dos cidadãos) e governo. Na República, não haveria uma divisão do trabalho entre cidadãos dedicados à atividades não políticas, de reprodução econômica, e cidadãos dedicados às atividades políticas, sendo o governo o conjunto dos seus “cidadãos". Já o "modo estatista" de governar apresenta uma clara separação entre a civitas e o "Estado":

“O modo estatista de administração se insinua quando pressões contrárias dos deveres políticos da cidadania e dos deveres sociais da reprodução material levam os cidadãos a admitir uma espécie de 'divisão do 
trabalho' de segunda ordem. Quer dizer, não a divisão para produzir commodities, mas a divisão entre as atividades não políticas e as atividades políticas - inclusive e principalmente as militares -, introduzindo portanto a especialização dessas últimas" (ARAÚJO, 2004, p. 66).

Araújo concorda com a definição de Quentin Skinner, para quem a concepção de Estado que prevaleceu no mundo moderno seria duplamente abstrata e impessoal. Segundo Araújo, essa concepção de Estado: "é pensada não só como uma entidade distinta das pessoas dos governantes, mas também - e aqui está a novidade que só se tornará categoria teórica entre pensadores contratualistas modernos - distinta da civitas, a comunidade dos cidadãos" (ARAÚJO, 2004, p. 67). Para Araújo, os sinais desta separação entre civitas e Estado seriam o surgimento de uma burocracia profissional e de um exército permanente e profissionalizado que se ergue por sobre a civitas. Estas duas instituições requerem, para seu financiamento, um sistema de tributos permanente. Nada disso existia nas cidades-estado antigas: o exército era na verdade uma milícia de cidadãos que se reuniam em caso de guerra, mesmo em Roma (FINLEY, 1983, p. 28); não existia uma força policial organizada para repressão interna ${ }^{107}$; os ocupantes dos cargos do Estado não eram "burocratas profissionais", eram cidadãos escolhidos por sorteio ou por eleição, e com mandatos em geral de um ano ou dois anos, com algumas exceções (FINLEY, 1983; HANSEN, 1999; MANIN, 1997); os serviços públicos e festas públicas não eram mantidos por um sistema permanente de tributos, mas por contribuições dos ricos, geralmente com tributos obrigatórios apenas em situações de guerra e recaindo principalmente sobre os mais ricos (FINLEY, 1983, p. 46).

Em resumo, o "modo estatista" de governar não existia nas cidades-estado gregas ou em Roma e apenas se insinua nas cidades italianas do renascimento. Quer dizer, nas cidades-estado

\footnotetext{
107 'Nem a ação policial contra os maus elementos, nem as medidas de crise contra a 'subversão' em larga escala nos informam sobre a usual capacidade da cidade-estado grega ou de Roma para fazer cumprir as decisões governamentais, que iam da política externa à aplicação de impostos e ao direito civil, quando é evidente que lhes faltavam meios para, tal como diz Laski na sua linguagem vigorosa, 'coagir os opositores do governo, dobrar-lhes as vontades, levá-los à submissão" (FINLEY, 1983, p. 37)
} 
não existiam os meios concentrados de coerção que passarão a existir na forma estatista, o que as tornava mais vulneráveis à stasis e à hybris. Por esse motivo, a reflexão sobre a stasis e sobre a hybris assume tamanha importância entre os antigos e dela emerge a questão: como manter a unidade da cidade frente ao crescimento do "particularismo" (partes da cidade em confronto stasis - concepções "particulares" de bem promovidas por sofistas e filósofos e que poderiam levar à corrupção dos costumes, ao excesso, à violência, à desmedida - hybris). Como evitar que a polis se autodestrua por meio da hybris e da stasis?

Em razão da ausência de meios concentrados de coerção, a preservação da ordem dependia muito mais dos costumes. É nesse contexto que o discurso das virtudes tinha centralidade política. As "repúblicas" dependiam ainda mais dos costumes do que os impérios antigos. Os impérios em geral eram mais "liberais" em relação a costumes e mais cosmopolitas que as repúblicas. Os impérios possuíam alguns traços semelhantes ao "modo estatista" de governo típico do Estado moderno: tributação direta; exércitos permanentes e mercenários, eventualmente com cidadãos de diversas nacionalidades; polícia; especialistas em assuntos jurídicos e sacerdotes religiosos ligados ao Estado e com monopólio interpretativo.

Nessa configuração institucional, existem muitos mecanismos de poder concentrados e "externos" à civitas que poderiam conformar as vontades e dobrá-las em caso de necessidade. Nos impérios antigos ou despotismos "orientais", a ordem social era mantida de modo "externo" e por isso poderia conviver com um grau de pluralismo que não era encontrado nas cidadesestado que organizavam-se na forma "república", já que os indivíduos de distintos povos e religiões no interior do Império não teriam força suficiente para ameaçar o poder do Império e não era necessário um tipo específico de religião que estimulasse o civismo. Entretanto, essa forma externa de governo, para os cidadãos das antigas repúblicas, era uma forma de governo despótica e inaceitável, pois ser livre para eles era influir diretamente nos destinos da polis. 
Na ausência de meios concentrados de coerção externos à civitas, capazes de "dobrar as vontades" em caso de necessidade, a ordem, a unidade da polis, dependia de um processo de formação das vontades, quer dizer, de uma Paideia que formasse as vontades para quererem o bem comum, essa formação era uma estilização das vontades operada pela Cultura. A religião cívica, o culto aos heróis, as festas públicas, o serviço militar, a preocupação com a preservação dos costumes eram meios para a formação das vontades, eram meios para evitar a hybris. A relativização da tradição pelos sofistas e filósofos e a introdução de novas crenças eram vistas com receio, pois poderiam corromper os cidadãos e com isso levar à perda de liberdade. Desde os poetas trágicos, dos comediógrafos e de filósofos antigos (como Platão e Aristóteles) até Hegel, passando Montesquieu, Rousseau e os Federalistas, todos enfatizavam a "corrupção" entre as causas para a decadência das repúblicas antigas e os seus sucessos eram explicados pela virtude dos seus cidadãos. O crescimento do “individualismo" e a erosão dos costumes tradicionais foi apontado por inúmeros observadores antigos e modernos como causas para a decadência de Atenas ${ }^{108}$.

Para Finley, a cultura era responsável, em grande medida, pela longa duração das cidades-estado, apesar da ausência de meios concentrados de coerção: os costumes, a religião nacional, o patriotismo e os valores hierárquicos eram incorporados na educação de todas as classes, "educação no sentido em que lhe deu Durkheim, distinguindo-a de pedagogia"

\footnotetext{
108 Alguns deles são: ARISTÓFANES, 2000; MONTESQUIEU, 2005; PAINE, 1989; HEGEL, 1942; GLOTZ, 1928; ROMILLY, 1970. Alguns trechos representativos desta visão: "O desenvolvimento subsistente por si da particularidade mostra-se, nos Estados antigos, como o momento em que irrompe a corrupção dos costumes e como fundamento último da decadência destes" (HEGEL, 2000, p. 18); "Não seria possível manter indefinidamente o feliz equilíbrio que a Grécia, em seus dias mais gloriosos, lograra estabelecer entre poder público e os direitos do indivíduo. Depois de ter auxiliado a cidade a dobrar a família patriarcal, o individualismo deixara-se, por algum tempo, conter, de um lado pela organização sempre sólida da pequena família, e, sobretudo, de outro lado, pela lei, que parecia inquebrantável, do Estado. Mas o direito do indivíduo iria degenerar em egoísmo. Mediante exigências cada vez maiores, mediante apetites que, cada dia, era mais difícil satisfazer, solaparia a família e arruinaria a cidade" (GLOTZ, 1928, p. 243); "O impasse a que chega a tragédia grega, no dia em que um dos seus elementos constitutivos perde o essencial da sua função, coincide com o impasse a que Atenas chega no dia em que o individualismo triunfa sobre o civismo, tal como a irreligião sobre a piedade, e em que o futuro do homem parece, no fim de contas, ser para repensar". (ROMILLY, 1970, p. 51)
} 
(FINLEY, 1983, p. 41). Entretanto, Finley não considera que o fim da democracia ateniense tivesse origem interna, quer por uma intensificação da stasis ou em razão da "decadência dos costumes". Para ele, os fatores determinantes foram externos a Atenas: "impôs-se um poder superior: as guarnições macedônias de Atenas e os exércitos que se movimentavam na zona foram as forças que finalmente tomaram as decisões (...) Depois de 261 a.C., Atenas entrou em definitivo nas fileiras das cidades-estado subjugadas, com uma vida política mesquinha, vítima da força externa superior" (FINLEY, 1983, p. 142) ${ }^{109}$.

De qualquer forma, mesmo nas análises de Finley, os costumes tinham importância maior para a unidade social nas repúblicas do que nos impérios. Por isso, a filosofia, ao relativizar os mitos e valores que formavam a base da educação (paideia), era vista como uma ameaça para a cidade $^{110}$. Por esse motivo, Platão decidiu estabelecer uma distinção entre ensinamento esotérico e exotérico, considerou os mitos indispensáveis para o grande público e tratou de tentar desvincular a filosofia da sofística, pois também considerava, como Aristófanes, que o livre

\footnotetext{
${ }^{109}$ Mossé também questiona a tese de que o século IV tenha sido de decadência da democracia: "Longe de ser um século de declínio, o século IV é, ao contrário, o século em que se consolidam as instituições democráticas, em que se constitui um sistema político coerente, longe das 'improvisações' do século anterior. Impossível não se render a essas evidências (...) A democracia ateniense funcionou, e funcionou bem, no século IV, sem ter sido questionada de fato, exceto no âmbito das escolas filosóficas. E só a vitória macedônia de 322, logo depois do levante provocado pelo anúncio da morte de Alexandre, privará Atenas de um regime político que fizera sua grandeza, mas que, quando vier a ressurgir de forma mais ou menos regular, no curso das décadas seguintes, já não passará de uma democracia formal (MOSSÉ, 2008, p. 242-3)

${ }^{110}$ Muitos atenienses nutriam preconceitos contra os filósofos e sofistas, que eram vistos como pessoas excêntricas, professores da arte de enganar, entre outros rótulos pejorativos. Na opinião popular, não se estabelecia diferença entre sofistas e filósofos. O comediógrafo Aristófanes expressou esse sentimento popular e apresentou o problema político da relativização dos costumes e valores no centro de sua peça "As Nuvens". Nesta peça, Sócrates é visto como alguém que vive fora da realidade, construindo teorias excêntricas e ensinando aos cidadãos - como um sofista - a arte de convencer usando raciocínios, fosse a causa justa ou injusta. O ensinamento de Sócrates seria, portanto, promotor de corrupção. A peça narra a estória de Strepsíades, um cidadão ateniense que estava muito endividado por conta das extravagâncias do seu filho Fidípides, que gastava todo o dinheiro do pai com cavalos. Desesperado e sem dinheiro para pagar os seus credores, Strepsíades se dirige ao "pensatório" - onde funcionava a escola de Sócrates - para que Sócrates o ensinasse a enganar seus credores através da argumentação e assim pudesse se livrar das dívidas. Mas, no meio do curso de Sócrates, Strepsíades se entusiasma com as aulas e pede para o filho que freqüente o curso também, e o filho Fidípides, depois de ter lições com Sócrates, passou a questionar não só os deuses como também chegou a espancar o seu próprio pai e a mãe. A filosofia, ao questionar valores fundamentais, levou a uma subversão da ordem. Aristófanes deixa nas entrelinhas a ideia de que para que exista ordem social, é preciso que certos valores não possam ser questionados, que não possam ser objeto de cálculo. No final da peça, Strepsiades toca fogo no pensatório de Sócrates. Para o poeta Aristófanes e os porta-vozes da tradição, a filosofia precisa ser expulsa da polis. Ver: ARISTÓFANES, 2000.
} 
pensar era potencialmente uma ameaça para a unidade da cidade. Tanto Platão quanto os poetas entendiam-se como educadores preocupados com a unidade da cidade, divergindo apenas em qual seria a educação mais adequada para este objetivo de evitar a hybris.

As cidades-estado gregas e Roma viveram conflitos frequentes entre os nobres e os comuns, entre ricos e pobres, conflitos às vezes abertos e violentos, outras vezes moderados e no interior das instituições. A palavra grega stasis, que muitas vezes é traduzida como guerra civil, não pode ser reduzida apenas a esta tradução, pois possuía um leque de significados que incluía diferentes níveis de intensidade do conflito, abrangendo tanto o conflito mais violento quanto uma tensão "normal" entre ricos e pobres:

"Houve anos de conflito da máxima intensidade em que a guerra civil podia ter rebentado, mas a maior parte deles foi de tranquilidade, anos durante os quais prosseguiu o processo de mudança constitucional, a um ritmo irregular, através de manobras políticas dentro da classe dirigente contra um fundo de descontentamento popular. Todos os níveis de intensidade foram abrangidos pela esplêndida palavra grega stasis." (FINLEY, 1983, p. 130)

O nível de intensidade da stasis poderia variar, mas segundo Finley, é impossível negar a sua existência e o fato de que, nas cidades-estado gregas e em Roma, o conflito entre ricos e pobres era causa de uma grande instabilidade nas formas de governo, que oscilavam entre oligarquias e democracias, passando por tiranias:

"Cidade após cidade, oscilava-se entre a oligarquia e a democracia com acompanhamento de guerra civil, de morticínio indiscriminado, exílio e confiscação. Por vezes, intervinham os tiranos, adicionando ao ciclo uma outra dimensão". (FINLEY, 1983, p. 126)

Estes conflitos entre as partes da cidade eram percebidos pelos próprios escritores antigos, tanto poetas e historiadores quanto filósofos. Para Finley, o pensamento político antigo considerava as diversas formas de governo como expressão de diferentes classes sociais em conflito $^{111}$, e esta noção, presente em Platão e Aristóteles, seria largamente partilhada entre os

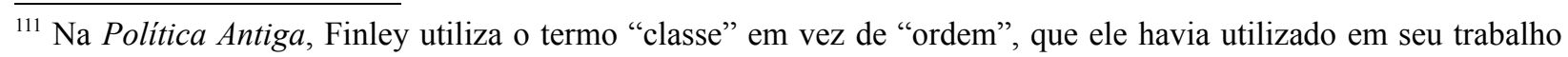


gregos. O próprio ideal de constituição mista, formulado pelos filósofos ${ }^{112}$, não seria o mesmo que um sistema de pesos e contrapesos, mas sim um governo misto de classes sociais que pretendia por um fim à stasis ou mantê-la em um nível que não levasse à autodestruição da cidade. Um sistema de pesos e contrapesos seria, segundo Von Fritz, "de natureza puramente funcional e praticado em nível governamental" (VON FRITZ, citado em ARAÚJO, 2004, p. 29), enquanto o governo misto atuaria como um equilíbrio de poder entre classes sociais.

Para Araújo, pensadores antigos, como Aristóteles, Políbio e Cícero também pensaram na dimensão de "sistema de freios e contrapesos" em suas constituições mistas, e não apenas na dimensão de equilíbrio de poder entre classes sociais, pois quando trataram da democracia ateniense, onde o demos governava praticamente sem a concorrência de um poder aristocrático que pudesse limitar seu poder, notavam, nesta mesma democracia, "algum sistema de divisão de funções constitucionais, com agências competindo entre si” (ARAÚJO, 2004, p. 30). Segundo Finley, a constituição mista, com seu incipiente sistema de pesos e contrapesos e sua busca de um equilíbrio entre classes ou ordens sociais, surgiu na prática política antes das formulações teóricas dos filósofos e historiadores e era amplamente encontrada nas cidades-estados gregas e em Roma. Para Finley, a tripartição de poder das constituições mistas, formada por Assembleia, Conselho e Magistraturas (Homens elegíveis e funcionários responsáveis pela tomada de decisões em áreas específicas), que remete em parte à nossa ideia de um sistema de pesos e contrapesos, era praticamente um sinônimo do governo das cidades-estado:

“Todo governo de uma cidade-estado englobava, pelo menos, uma assembleia ampla (e, regra geral, apenas

anterior, A Economia Antiga. Mas Finley esclarece em nota que utiliza classe em um sentido comum, para se referir ao conflito entre ricos e pobres, e não num sentido "técnico marxista" (FINLEY, 1983, p. 34) Para Ste Croix, no mundo antigo já podemos falar em classe (a partir de posição de um grupo de indivíduos na divisão social do trabalho), em consciência de classe e em conflitos de classes que envolveriam até escravos (STE CROIX, 1981). Para Vernant (VERNANT, 1965) e Vidal Naquet (VIDAL-NAQUET, 1968) existiam classes, mas o conflito de classes ficou restrito ao conflito entre homens livres. Finley preferia o termo "ordens", mas também pensava como Vernant e Vidal Naquet que o conflito social estava restrito aos homens livres (FINLEY, 1983).

112 Segundo Finley, apesar do ideal de constituição mista ter sido formulado teoricamente pelos filósofos, a constituição mista não surgiu das sugestões dos filósofos, quando estes escreveram as constituições mistas já existiam e tinham sido o resultado dos conflitos sociais no interior das cidades (FINLEY, 1983, p. 74-5). 
uma), um conselho ou conselhos menores e um certo número de funcionários que se revezavam entre os homens elegíveis, a maior parte das vezes em uma base anual. Todos esses elementos - a composição dos grupos, o seu método de escolha, os poderes, os nomes por que eram conhecidos - variavam bastante ao longo do tempo e de lugar para lugar, mas o sistema tripartido era tão ubíquo que quase pode entender-se como sinônimo do governo da cidade-estado" 113

A constituição mista era o resultado de uma correlação de forças entre as diferentes partes da cidade. O predomínio de elementos democráticos ou oligárquicos em uma polis ou outra resultava das cambiantes correlações de forças. O processo de passagem da polis aristocrática para a polis democrática foi marcado por uma intensa stasis em todas as cidades-estado que viveram uma democratização, quer dizer, uma erosão ou perda do monopólio político dos oligarcas. As alterações nas correlações de forças estavam ligadas à uma série de transformações sócio-econômicas: crescimento da densidade demográfica, da divisão social do trabalho, do comércio, da navegação, houve também uma intensificação do contato com outras cidadesestado e povos da Grécia e do Mediterrâneo, ocorreram mudanças importantes no direito e surgiram novos graus de desenvolvimento da individualidade. Estas transformações permitiram o surgimento, em uma parte do demos, de um número considerável de comerciantes, de produtores de cerâmica e artesãos prósperos que passariam a contestar privilégios da antiga aristocracia, exigindo, por exemplo, plenos direitos políticos e leis escritas, em vez das leis orais e ditadas por aristocratas (as antigas themistes). Em seu lugar, surgiu uma nova concepção de justiça, a diké, nela as leis não são mais vistas como tendo origem divina, mas sim origem humana, sendo, portanto, modificáveis. Entre as parcelas mais pobres do demos passariam a ter relevância política a exigência do fim da escravidão por dívidas e a luta pela redistribuição de terras.

Apesar da sua importância, a ascensão política do demos/plebe não pode ser explicada apenas pela revolução econômica. As alterações na forma de realizar a guerra foram

\footnotetext{
${ }^{113}$ Finley, M. A politica antiga. Ed. Edições 70, p. 74.
} 
fundamentais neste processo. Em linhas gerais, a mudança principal consistiu na inclusão de setores cada vez mais amplos do povo nas fileiras do exército, formando a sua infantaria pesada. O exército hoplita substituiu as formações militares anteriores, que eram baseadas principalmente na cavalaria e que estavam restritas à participação dos aristocratas que podiam arcar com os custos de comprar e manter seu próprio cavalo e armas. Esses guerreiros aristocratas lutavam de modo mais livre, dependendo mais do heroísmo individual do que de uma estratégia elaborada que exigisse grande disciplina coletiva. No exército hoplita havia mais soldados, com a incorporação do demos, e maior estratégia e disciplina coletiva. Em pouco tempo, todas as cidades-estado adotaram a formação militar hoplita, pois as que não o faziam perdiam facilmente as batalhas. Cresceu um sentimento de injustiça entre esses soldados do demos, que contribuíam para a glória da polis, mas, ao retornar das batalhas, viam-se excluídos dos direitos políticos, adquiriam as piores terras ou nenhuma terra e poderiam tornar-se escravos por endividamento. A insatisfação popular cresceu, porém reforçada: agora o demos estava armado e fazia parte do exército de cidadãos. Para Weber, a mudança militar condicionou a luta contra a aristocracia:

“A queda das linhagens e o passo em direção à democracia foi condicionado pela mudança na técnica militar. O exército dos hoplitas, disciplinado e equipado por si próprio, foi quem levou a luta contra a nobreza e a derrubou militar e também politicamente" (WEBER, 1992, p. 1034)

O crescimento demográfico gerou pressão por terras, o problema agrário, por sua vez, constituiu um dos principais motivos da stasis. Portanto, a expansão territorial por meio da guerra funcionou também como um meio para aliviar a stasis interna. Finley destaca que as cidades-estado mais estáveis politicamente foram justamente os "estados conquistadores bem sucedidos, Esparta, Atenas e Roma" (FINLEY, 1983, p. 131). Finley considera que essas cidades-estado foram em grande medida estáveis, ao contrário de uma opinião estabelecida que 
as considerava extremamente instáveis, especialmente a democrática Atenas e a República romana. Estabilidade não significa, para Finley, uma harmonia total, uma ausência de stasis, mas apenas que as instituições políticas dessas cidades-estado viveram longos períodos de estabilidade, onde a stasis ocorria em níveis moderados, eventualmente entrecortados por períodos mais turbulentos, mas estes não seriam a regra na maior parte do tempo.

Nos períodos turbulentos, foi comum que alguns líderes militares se tornassem os “campeões do povo", que subiam ao poder de modo não tradicional, por meio de revolução ou golpe, e governavam acima das leis, que eram aristocráticas. Esse novo rei (tirano) apoiava-se no demos, contra os nobres. Em geral estes novos líderes eram provenientes de setores ascendentes do demos ou eram aristocratas que na disputa política contra outras famílias aristocráticas apoiavam-se no demos e obtinham assim mais poder contra seus adversários. Em todas as cidades-estado gregas em que houve algum processo de democratização, a democracia foi precedida pela tirania. Nascem ambas do mesmo processo: da stasis, da erosão do poder da aristocracia tradicional e da ascensão política do demos.

As tiranias adotaram medidas democratizantes como redistribuição de terras e isonomia. Em Corinto, cidade comercial e produtora de cerâmica, a tirania de Cipselo realizou estas medidas. Em Atenas, fracassou a tentativa de Sólon de realizar algumas concessões à plebe para amainar a stasis e com isso afastar o risco de tirania. Durante a intensificação dos conflitos sociais, Pisístrato tornou-se tirano de Atenas, chegando ao poder por meio de um golpe, em 561 a.C. Em seu governo, Pisístrato apoiou-se nos setores populares, governando em geral à revelia dos desejos dos nobres, que foram reprimidos politicamente, inclusive com episódios de violência. Entre suas medidas mais importantes estão: a realização de uma reforma agrária, que beneficiou os pequenos agricultores; a manutenção de uma ampla rede de aliados de Atenas, que fortaleceu o poder imperial ateniense; a promoção de um grande crescimento do comércio e do 
poder naval de Atenas; e o estímulo à atividades culturais e religiosas.

A tirania de Pisístrato teve apoio popular e realizou mudanças igualitárias, entretanto, depois da sua morte, assumiram o poder os seus filhos, Hípias e Hiparco, que não tinham a mesma capacidade política que o pai para conquistar o apoio do povo e teriam abusado do poder, restringindo ainda mais a liberdade dos cidadãos e adotando medidas impopulares, como o aumento de impostos para financiar sua guarda pessoal. A insatisfação cresceu, Hiparco foi assassinado, Hípias escapou do atentado, mas em poucos anos foi derrubado com a ajuda dos espartanos e em um contexto de luta pela democracia.

Com a queda da tirania abriu-se uma luta política, a partir da qual Clístenes foi alçado ao poder, vencendo a facção política que era apoiada pelos espartanos. Clístenes foi escolhido pela assembleia dos cidadãos para reformar as leis e esta reforma implantaria a democracia. A antiga estrutura aristocrática da cidade, que vinculava os direitos de cidadania aos laços de parentesco, foi superada. Além da isonomia, a isegoria (igual chance de participação política) tornou-se um dos princípios da "constituição" ateniense. Para realizar este princípio, o sorteio passou a ser a principal forma de escolha de cidadãos para os cargos públicos. Todos os homens livres, até mesmo os Tes (sem terra pobres), tinham direito de submeter seu nome ao sorteio e participar da Assembleia, permaneceram excluídos dos direitos políticos, como se sabe, os escravos e as mulheres. A eleição era utilizada apenas para alguns cargos, como, por exemplo, o de estratego (chefe militar). A assembleia de cidadãos era a principal instituição política. A participação na assembleia era voluntária e depois passou a ser remunerada, para permitir a participação dos que precisavam trabalhar. O Estado, com Péricles, passou a ajudar financeiramente os mais pobres, o que minou em parte as relações de clientela que alimentavam o poder político das famílias nobres. O Estado passou a patrocinar festas públicas e encenações, que antes eram financiadas por homens ricos com ambições políticas. 
É nesse contexto de democratização e erosão do poder das oligarquias que surgem as tragédias gregas. A primeira representação trágica teria sido As dionisíacas atenienses, em 534 a.C., sob o governo do tirano Pisístrato. Entretanto, a primeira tragédia conservada foi $O s$ Persas, de Ésquilo, em 472 a.C., escrita e encenada logo após à vitória de Atenas sobre os invasores persas na batalha de Salamina. As últimas tragédias importantes foram encenadas até 404 a.C., quando Atenas perde a guerra do Peloponeso e o seu império. As obras-primas da tragédia grega situam-se neste período, de cerca de 80 anos, entre o auge e a decadência de Atenas (ROMILLY, 1970, p. 51).

Para muitos, trata-se da época gloriosa de Atenas, máxima expressão da cultura ática e da democracia ateniense. Em razão das tragédias surgirem nesse momento de ascensão do demos, não é simples coincidência que as encenações de tragédias tenham origem no culto de Dionísio, pois o dionisismo era um culto religioso no qual todas as diferenças de status eram abolidas, um culto aberto a participação de mulheres e escravos. Tratava-se de um culto popular, diferente do culto cívico dos deuses olímpicos, mais associado às diferenças de status. As festas de Dionísio, celebradas na primavera, eram festas nacionais, com procissões, sacrifícios, música, coral e uso de máscaras. Para Aristóteles, as primeiras encenações trágicas teriam surgido de improvisações nestas festas. Mas as encenações de peças trágicas adquiriram autonomia em relação a esta origem religiosa, sem deixar de apresentar uma presença do sagrado. ${ }^{114}$ A distância em relação a esta origem religiosa acentua-se com o passar dos anos, o que pode ser percebido nas mudanças entre os principais poetas trágicos começando com Ésquilo, o mais antigo e piedoso, passando por Sófocles e chegando em Eurípides, considerado mais o mais racionalista.

Passaram a ser realizados concursos de peças trágicas nas festas de Dionísio. Todo o povo

\footnotetext{
114 “Mas essa inspiração religiosa foi apenas um primeiro impulso, pois não encontramos nas peças trágicas nada que lembre particularmente Dionísio, o deus do vinho e das procissões fálicas, nem mesmo o deus que morre e renasce com a vegetação; mas encontramos sempre uma certa presença do sagrado, que se reflete no próprio jogo da vida e da morte" (ROMILLY, 1970, p. 13).
} 
era convidado a assistir aos espetáculos patrocinados pelo Estado. Desde a época de Péricles, os cidadãos pobres podiam até receber um abono para poderem assistir às representações. Para Romilly, o patrocínio do Estado às encenações trágicas só pôde acontecer quando surgiu uma autoridade política que se apoiava no povo, no início essa autoridade era a tirania, depois a democracia:

"A tragédia grega não poderia ter nascido a não ser que estas improvisações religiosas, de onde deveria sair, se encontrassem entregues e organizadas por uma autoridade política que se apoiava no povo. Através de um traço assaz notável, o nascimento da tragédia está associado, em quase todo o lado, à existência da tirania - isto é, de um regime forte que se apoiava no povo contra a aristocracia” (ROMILLY, 1970, p. 15).

Apesar deste novo contexto histórico, como já mencionamos, o conteúdo das tragédias era formado pelos mitos e heróis da época homérica, com sua ética heroica e sua aristocracia guerreira. A valentia, a honra e a iniciativa individual permaneciam admiradas, mas não poderiam ter o mesmo significado em uma sociedade mais estável, com maiores períodos de paz, com leis escritas, participação popular na assembleia, no conselho (Boulé) e na justiça. Vernant entende que as tragédias foram escritas em um momento de tensão entre o pensamento legal e político de um lado, e as tradições míticas e heroicas por outro lado (VERNANT, 1999, p. 4).

As mudanças no direito também envolveram o início do estabelecimento de diferenças na gravidade das sanções penais em função da intencionalidade ou não de um crime, premeditação ou não, o que envolvia uma averiguação inédita das intenções subjetivas do agente. Essa mudança jurídica envolve uma mudança moral: a noção de responsabilidade, culpabilidade pessoal e valor ${ }^{115}$. Para Vernant, o constante questionamento da agência individual é uma característica do gênero trágico e seria expressão daquilo que ele chamou de "Esboços da vontade na tragédia grega", entendendo "vontade" na sua concepção racionalista (VERNANT,

\footnotetext{
${ }^{115}$ Segundo Dodds, ocorre uma passagem da "cultura da vergonha" para a "cultura da culpa" (DODDS, 1951)
} 
1999, pp. 25-52), "vontade” que na Grécia estaria apenas esboçada ${ }^{116}$. Os homicídios passaram a ser julgados pelo Estado, e não mais pelas famílias. A vingança passou a ser proibida. Todas essas mudanças restringiam a iniciativa individual dos antigos aristocratas. A iniciativa individual, própria dos heróis, perdia espaço para a "obrigação social" em mundo em que a “comunidade" passa a ter um peso cada vez maior"117.

Nas tragédias, o herói já aparece como problema, tal como no diálogo de Ájax que citamos na abertura deste capítulo, quando Ájax diz que um "nobre ou vive na beleza ou nela morre" e o Corifeu responde "ninguém dirá que teu discurso é ambíguo", e acrescenta, "contudo pára, deixa que teus amigos anulem teu projeto, joga-o fora”. Ájax estava enlouquecido, atacara porcos pensando que eram os soldados de Odisseu, fora enganado pela deusa Atenas, alguém precisava trazê-lo de volta ao bom senso, seu apreço pela honra era exagerado, era uma hybris que o cegou. Entretanto, as tragédias não condenam o herói duplamente por seus erros. Ájax era irascível, era seu temperamento, foi enganado pela deusa, daí deriva uma sucessão de fatos que o levaria ao suicídio.

Na mesma peça, Odisseu aparece como um herói equilibrado, que respeita a lei e quer dar enterro digno a Ájax, apesar dele ter tentado matá-lo, porque, disse Odisseu: apesar de inimigo "tinha fibra nobre" e "virtude conta mais que a inimizade" 118 . As tragédias não pretendiam 116 Sobre a visão tradicional que se tinha da Grécia como uma cultura racionalista, Dodds se pergunta por que nós
deveríamos atribuir aos gregos antigos uma imunidade aos modos "primitivos" de pensamento se nós não
encontramos isto "em nenhuma sociedade aberta à nossa observação direta"? (DODDS, 1951, p. viii)
117 "El hecho es que aquel concepto de obligación social es fundamentalmente no heroico. Refleja el nuevo
elemento, la comunidad, en el único punto en que era permitido desatender cualquier otra cosa: el punto de defensa
contra un invasor. En las generaciones siguientes, cuando la comunidad comenzó a moverse desde los flancos al
centro del escenario griego, el héroe desapareció rápidamente porque el honor del héroe era puramente individual,
algo por lo cual vivía y luchaba por su proprio valor como por si mismo. (La adhesión a la familia era permitida,
porque el parentesco era indistinguible del individuo mismo). El honor de una comunidad era una cualidad
totalmente diferente, que exigía otro orden de habilidades y virtudes; de hecho, la comunidad solo podía prosperar si
domaba al héroe y ponía obstáculos al libre ejercicio de su valentía, y un héroe domesticado era una contradicción
en sí mismo". (FINLEY, 1954, p. 130)
118 A estima por Odisseu, um herói equilibrado, e o suicídio de Ájax, o irascível, não significa um abandono do
"agonismo" ou dos "valores competitivos". Para Adkins, a Grécia teria experimentado uma passagem de um
momento em que prevaleciam "valores competitivos" para um período (clássico) em que prevaleceriam "valores
cooperativos". (ADKINS, 1960). Contudo, a tese de Adkins foi bastante contestada, especialmente porque não há
evidências textuais em Homero da ausência ou menor importância de "valores cooperativos", eles estavam presentes 
resolver o problema da unidade da cidade por meio do racionalismo moral que começava a ser esboçado por Platão. A tragédia não representa nem a ética puramente heroica, nem o racionalismo moral. O herói permanece, mas é problematizado, o popular aparece, o dionisismo também, o legado homérico não é descartado, mas reinterpretado, pois a tragédia pertence à cidade democrática. ${ }^{119}$

\section{A CRÍTICA DE PLATÃo AOS TRÁGICOS}

“Quando Platão, na República, apresenta sua própria teoria coerente e bem-integrada das virtudes, sua estratégia é, em parte, expulsar da cidade-estado o legado homérico" (MACINTYRE, 2001, p. 226)

A filosofia política nasceu com Platão e sua questão central era: como manter a unidade da cidade e o bem comum evitando a hybris (desmedida) e a stasis (guerra civil)? A resposta platônica resultou em uma posição hostil aos aspectos trágicos da cultura grega, à democracia e à própria concepção de liberdade da polis $^{120}$. Sabe-se que Platão nasceu em uma família aristocrática e abastada, o que lhe permitiu viajar a diversas regiões do Mediterrâneo, viagens que o seu mestre, Sócrates, não havia conseguido fazer. É provável que essas viagens tenham influenciado seu pensamento, especialmente sua possível passagem pelo Egito, onde teve contato com outra cultura, religião e forma de organização política, bastante diferentes da trágica cultura grega, da religião grega e da democracia ateniense. O filósofo antigo Numênio chegou a dizer “o

e apareciam na amizade entre guerreiros, união, fidelidade, hospitalidade e alianças, assim como não desaparecem os valores competitivos no período clássico (LONG, 1970).

${ }^{119}$ Castoriadis chega a dizer que o teatro trágico só poderia ter nascido na Atenas democrática: "Existe somente uma tragédia ateniense. Pois a tragédia (em oposição ao simples 'teatro') não poderia mesmo nascer em outro lugar que não na cidade onde o processo democrático, o processo de auto-instituição atingiu o apogeu" (CASTORIADIS, 2002, p. 316). Sobre esse aspecto democrático Hall observa: "Tragedy offers a range of characters of all statuses from gods and kings to citizens and to slaves, all ethnicities from Athenian, Theban, and Argive Greeks to 'barbarians' (the generic term for non-Greeks) such as Persians and Egyptians, all age groups from babies to the very old, and an overwhelming insistence on the troubled relationships between woman and men" (HALL, 1997, p. 95)

120 "Platão, o pai da filosofia do Ocidente, tentou de várias maneiras contrapor-se à polis e aquilo que ela definia por liberdade. Tentou-o por meio de uma teoria política na qual os critérios da coisa pública não são criados a partir da própria política, mas sim da filosofia, por meio de uma constituição que entrava em pormenores, cujas leis correspondem às ideias acessíveis apenas aos filósofos" (ARENDT, 2007, p. 62) 
que é efetivamente Platão senão um Moisés que se aticiza?’. ${ }^{121}$

Tendo viajado ao Egito ou não, o fato é que a cosmologia de Platão difere muito da tradição trágica dos gregos, com sua noção de Caos insondável, seu politeísmo sem teleologia, sua ausência de uma teoria da alma e de um mundo transcendente e verdadeiro, com sua correspondente ideia de Bem ${ }^{122}$. Em Platão já há um mundo transcendente e verdadeiro acessível ao filósofo por meio do conhecimento verdadeiro (episteme) -, separado deste mundo da aparência, que é governado pelas opiniões $($ doxa $)$; o divino só é fonte do bem; há uma teoria da imortalidade da alma, de origem oriental, embora existam controvérsias a respeito da semelhança ou não entre o conceito de alma em Platão e o da religião judaico-cristã. Outra diferença notável entre Platão e a tradição trágica é o otimismo a respeito da capacidade humana de conhecer, embora não fosse um otimismo tão intenso quanto aquele que existirá no iluminismo, pois em Platão o conhecimento da verdade seria alcançado apenas por uma minoria, permanecendo a maioria no terreno da opinião, disto resulta a já mencionada separação entre ensino esotérico e exotérico. Também é por esse motivo que Platão não critica os poetas por criarem mitos, mas por criarem mitos que não são belos nem úteis para o bem da cidade. Escreve Platão:

“- Em primeiro lugar, então, devemos manter vigilância sobre os que criam os mitos e, se criarem um belo mito, deveremos incluí-lo em nossa seleção e, se não, excluí-lo. Os mitos que forem escolhidos nós persuadiremos as amas e as mães que os narrem às crianças e com eles moldem as almas delas muito mais que com suas mãos lhes

\footnotetext{
121 “Com efeito, o nome de Platão está associado a essa 'abertura' da sabedoria grega para o Oriente. Mas que abertura? Para que Oriente? Como sempre no que diz respeito a Platão, as coisas tornam-se logo inextrincáveis. Terá ele de fato viajado ao Egito? Viajante do Egito ele é, sem dúvida - mas pode-se duvidar se ele de fato foi ao Egito. Em todo caso, é um dos maiores viajantes, no sentido que damos ao termo, da e na sophia grega (...) Menos de um século mais tarde, sob os Antoninos, o filósofo Numênio, originário de Apaméia, poderá inscrever definitivamente Platão na configuração oriental do saber, respondendo à questão: 'O que é efetivamente Platão senão um Moisés que se aticiza?"” (HARTOG, 2004, p. 20-21).

${ }^{122}$ Kaufmann apontou a afinidade entre Platão e as doutrinas indianas antigas: "In a way, the answer is given in the concluding myth: Plato agrees with ancient Indian doctrines not only insofar as he considers the world of sense perception mere appearance but also by inviting us to entertain a belief in the transmigration of souls and by holding that, according to an immanent law that requires no divine intervention, our reincarnation depends on our justice or injustice in this life. It is entirely possible that Plato himself believed this; but if he did not, then this myth is an example of the kind of poetry permitted and needed in the ideal city" (KAUFMANN, 1992, p. 23).
} 
moldam os corpos. Muitos dos mitos que elas hoje narram às crianças devem ser jogados fora. (...) Os que Hesíodo e Homero contavam, falei, e também outros poetas. Foram eles que compuseram esses mitos mentirosos e os narravam e narram ainda aos homens. - Quais são eles? Disse. Neles, o que censuras? - O que se deve censurar, disse eu, em primeiro lugar e acima de tudo, é que a mentira não seja bela.” (PLATÃO, REPÚBLICA, 377c-e, p. 75).

Portanto, não devemos nos enganar com a consideração de Platão a respeito da superioridade da filosofia sobre a poesia e a arte em geral. Não se trata de expulsar a poesia da cidade, nem de fundar a cidade sobre a verdade: Platão não imagina uma sociedade totalmente transparente em que todos os cidadãos são filósofos. Platão considerou a filosofia como superior à arte porque ela permitiria o conhecimento do mundo das ideias, o mundo verdadeiro, enquanto a arte seria sempre uma imitação (mímesis) do mundo da aparência. Quer dizer, a arte seria uma imitação da imitação, pois o mundo da aparência já era uma pálida imitação do mundo verdadeiro. Entretanto, apesar da inferioridade da poesia, ela não é dispensável para a cidade, nem mesmo a mentira é dispensável, diz Sócrates:

“É que, se tínhamos razão no que dizíamos há pouco e se realmente para os deuses a mentira é inútil, enquanto aos homens é útil à guisa de remédio, evidentemente tal remédio deve ser entregue a médicos e ficar fora do alcance de quem não é da profissão. - Evidentemente, disse. - Aos que governam a cidade, mais que a outros, convém mentir ou para beneficiar a cidade, ou por causa de inimigos ou de cidadãos, mas tal recurso não deve ficar ao alcance dos demais" (PLATÃO, REPÚBLICA, 389b-c, p. 92).

Para Platão, a mentira é útil aos homens como "remédio", mas os remédios devem ser administrados por médicos, por especialistas. O recurso à mentira pode ser necessário para "beneficiar a cidade" ou "por causa de inimigos ou de cidadãos", desde que este recurso esteja ao alcance apenas dos que governam, e devem governar os filósofos, que detém o conhecimento verdadeiro, quer dizer, para Platão a verdade não pode ser democratizada, pois os homens tem diferentes inclinações naturais, eles não nascem iguais em habilidades, nem todos teriam 
inclinação natural para a filosofia. No homem democrático, prevalece a parte concupiscível ou sensível da alma, e ele seria motivado por essas inclinações sensíveis e não pela busca de honra ou do conhecimento verdadeiro. No homem timocrático ou ambicioso, a parte irascível da alma comanda as outras e ele é motivado pela busca de honra e senso de dever. Nos filósofos, que são uma minoria dos homens, prevalece a parte racional da alma sobre as outras e ele é motivado pela busca do conhecimento verdadeiro.

Estes diferentes tipo de homens devem estar agrupados em estamentos, não pelo seu nascimento em uma classe ou outra, mas de acordo com suas inclinações naturais a serem descobertas em uma espécie de ciclo básico de educação. Assim, a República seria dividida em estamento dos artífices, estamento dos guerreiros e o estamento dos guardiões, este, formado pelos filósofos, comandaria a República. Os guardiões/filósofos, sabendo distinguir o ensinamento esotérico do exotérico, deveriam saber manejar os mitos e as mentiras de acordo com o bem da República. Esse habilidade não poderia ser estendida ao conjunto dos cidadãos, pois poderia destruir a unidade da República por meio da proliferação de opiniões divergentes, que enfraqueceriam os costumes comuns, promovendo corrupção. As opiniões (Doxa), ao contrário da episteme, tenderiam a aderir aos interesses particulares, sendo incapazes de controlar a pleonexia, a ambição ilimitada de bens e honra, "ambição que toda natureza busca como um bem", ${ }^{123}$ vista por Platão como principal causa da stasis. 123 "Perceberíamos melhor que quem pratica a justiça só a pratica de má vontade, por incapacidade de cometer
injustiça, se imaginássemos algo como isso... Deixaríamos que aos dois, ao justo e ao injusto, fosse permitido fazer
o que quisessem; depois iríamos atrás deles observando para onde a paixão conduziria cada um. Em flagrante
apanharíamos o homem justo a buscar o mesmo alvo que o injusto, por causa da ambição de possuir sempre
mais, ambição que toda natureza busca como um bem e da qual, à força, a lei a desvia para levá-la ao respeito da
equidade" Grifos nossos (PLATÃO, REPÚBLICA, 359c, p. 50). Esta fala de Gláucon na República é uma das
demonstrações daquilo que Vegetti chamou de "antropologia da pleonexia", que estaria presente em diversos autores
do século V e IV a.C. em Atenas, entre eles Aristófanes, Tucídides, Eurípides, Górgias e no próprio Platão
(VEGETTI, 1999). Neste trecho, pleonexia foi traduzida como ambição. Sócrates admite que a vida movida pela
pleonexia é a vida da maioria das pessoas, mas acredita que os filósofos conseguem superar a pleonexia e olhar
"para cima", enquanto a maioria "olha para baixo", "à maneira dos bichos": "Ao contrário, à maneira dos bichos,
olhando sempre para baixo e debruçados sobre o chão e sobre as mesas, pastam empanturrando-se, acasalando-se e,
e por avidez [pleonexia] de tudo isso, distribuindo coices e marradas com seus chifres de ferro e armas, matam-se
uns aos outros sem se saciarem nem seu ser nem o que lhe serve de proteção. - De maneira perfeita, Sócrates, disse
Gláucon, como se fosse a resposta de um oráculo, descreves a vida da maioria das pessoas" (PLATÃO, 
Se o objetivo da filosofia política de Platão é a unidade da cidade, ele precisa encontrar uma solução que neutralize a pleonexia e elimine a influência de qualquer particularismo na condução do governo. Para tanto, os filósofos devem governar, pois neles a parte sensível e a parte ambiciosa da alma seriam mais fracas que a parte racional, e os filósofos/guardiões não devem possuir nem propriedade privada nem família, pois estas são também fontes de particularismo. A crítica de Platão aos poetas trágicos está subordinada aos objetivos de sua filosofia política. Não é tanto uma análise da forma artística da tragédia - como será em Aristóteles - mas sim uma análise do conteúdo das tragédias do ponto de vista dos efeitos da poesia sobre a formação dos cidadãos ${ }^{124}$.

Para Platão, os poetas não teriam entendido o divino e erram ao apresentar deuses mentindo, brigando, fazendo maldades, pois o divino deveria ser apresentado apenas como fonte do bem. Os fundadores da República devem orientar os poetas a apresentar os deuses como essencialmente bons:

“Adimanto, nem tu nem eu somos poetas neste momento, mas fundadores de uma cidade. Aos fundadores cabe conhecer os modelos segundo os quais os poetas devem compor os mitos, e não permitir que os componham sem ater-se a esses modelos. Não nos cabe, porém, compor mitos... - Estas certo, disse. Mas isso é que eu queria saber... Quais seriam os modelos a usar quando se fala sobre os deuses? (...) - Então? O deus é essencialmente bom... É isso que se deve dizer? - Sem dúvida.” (PLATÃO, REPÚBLICA, 379a-b, p. 77)

Deve-se dizer que o divino é essencialmente bom ${ }^{125}$. Para Platão, Homero e os outros

REPÚBLICA, 586b, p. 370)

${ }^{124}$ Platão demonstra preocupação especial com o efeito das peças trágicas sobre a formação das crianças: "Então sabes que, em todo trabalho, o mais importante é o começo, principalmente quando se trata de jovens e de crianças de tenra idade? É principalmente nesse momento que, na cidade, eles são plasmados e cada um recebe o molde que se quer imprimir em cada um deles." (PLATÃO, REPÚBLICA, 377b, p. 74)

${ }^{125}$ Segundo Kaufmann, essa é uma das novidades de Platão em relação à tradição grega, mas mesmo na tradição judaico-cristã, a ideia de que o divino só é fonte do bem e nunca do mal não estava presente no início, na parte mais antiga do velho testamento, e Kaufmann cita alguns trechos da bíblia que apresentam Deus como fonte do bem e também do mal (Amos 3.6; Lamentações 3.38; Isaías, 45.5; Jó, 2.10; Ezequiel, 18.2 f). Para Kaufmann, foi principalmente o novo testamento que desenvolveu a ideia de que Deus nunca faz o mal, ideia que havia sido esboçada no judaísmo do exílio. Segundo Kaufmann, Platão não defendeu a onipotência divina e sua luta não é contra o polité́smo em si, mas ao moralizar o divino, ele deu o mesmo passo que os judeus haviam dado pouco tempo antes (KAUFMANN, 1968, p. 12). 
poetas erram por não dizerem isso (PLATÃO, REPÚBLICA, 379c). Afirmar que os deuses também podem causar males não é nem "piedoso nem útil para nós" ${ }^{26}$, porque estimularia nos cidadãos, especialmente nos jovens ${ }^{127}$, a imitação destes deuses e heróis que realizam más ações. Os poetas deveriam promover a imitação apenas daqueles que devem ser imitados ${ }^{128}$. Os fundadores da República não devem tolerar que heróis e deuses sejam apresentados mentindo e nem se transformando ou usando disfarces, tal como era característico de Dionísio, o deus das metamorfoses $^{129}$.

Os poetas também erram porque tendem a glorificar o mundo, em vez de tentar direcionar as atenções dos cidadãos "para o alto". Platão afirma que deveria haver uma "arte do desvio" para mudar as atenções para a "direção correta" (PLATÃO, REPÚBLICA, 518d, p. 272). Ainda que Platão não acredite que todos os homens tenham vocação para a filosofia, ele defende que a poesia deveria ser edificante, estimular o interesse pelo outro mundo, o mundo verdadeiro. A poesia pode mudar a direção das atenções, e os poetas devem ser "imitadores de imagens da virtude" (PLATÃO, REPÚBLICA, 601a, p. 389). Apesar da "poesia não ser coisa séria"130, pode ser útil para a República, desde que encontremos um outro gênero de poeta, "mais austero" e “menos agradável”:

\footnotetext{
126 “A afirmação de que o deus, que é bom, é causa dos males de alguém é algo que devemos combater por todos os meios, para que nenhum cidadão o diga em sua cidade, se é que ela quer ter boas leis, e nem velhos nem jovens o ouçam dizê-lo em suas narrativas, em verso ou prosa, porque, se o dissessem, suas palavras não seriam piedosas, nem úteis para nós, nem coerentes com elas mesmas" (PLATÃO, REPÚBLICA, 380c, p. 79).

127 "É que o jovem não é capaz de discernir o que é alegoria e o que não é, mas, quando tem essa idade, o que apreende das opiniões costuma tornar-se indelével e imutável. Talvez seja por essas razões que se deve ter como muitíssimo importante que os primeiros mitos que os jovens ouçam sejam narrados da maneira mais bela possível para que os levem em direção da virtude". (PLATÃO, REPÚBLICA, 378c e 378e, p. 76-7)

128 "Mas, se imitam, que imitem já desde a infância aqueles a quem lhes convém imitar, isto é, os corajosos, os moderados, os piedosos, os que tem a nobreza do homem livre e tudo que tem essas qualidades. Não pratiquem nem sejam hábeis no imitar atos impróprios de um homem livre ou outro vício para que não venham a tê-los na realidade, como fruto da imitação. Não percebeste que, se as imitações perduram desde a infância vida adentro, as imitações se tornam hábito e natureza que mudam o corpo, a voz e o pensamento?" (PLATÃO, REPÚBLICA, 395c-d, p. 101)

129 “- Ah! O deus é completamente simples em seus atos e palavras, ele próprio não se transforma e não engana aos outros, nem com aparições, nem com palavras, nem com envio de sinais, quer em vigília quer sonhando" (PLATÃO, REPÚBLICA, 382e, p. 83)

130 "O imitador não conhece nada que valha a pena a respeito do que imita, mas, ao contrário, a imitação é uma brincadeira e não uma coisa séria, e os que se dedicam à poesia trágica em versos jâmbicos e épicos são imitadores tanto quanto se pode ser" (PLATÃO, REPÚBLICA, 602b, p. 391).
} 
“Nós, porém, precisaríamos de um poeta e de um narrador de mitos mais austero e menos agradável, mas útil, que imite a fala do homem de bem cujas palavras sejam conforme os modelos que, de início, fixamos como norma, quando tratávamos da educação dos guerreiros” (PLATÃO, REPÚBLICA, 398b, p. 105)

O poeta necessário à República deve ser austero, pois é preciso ensinar aos cidadãos a moderação e a coragem. Em vez disso, Homero e os poetas trágicos apresentam homens, heróis e deuses sem moderação, desrespeitando autoridades e empanturrando-se nos prazeres da bebida $^{131}$, da comida e do amor ${ }^{132}$. Em vez de estimular esses apetites que "causam dor", o poeta deveria deixar que "eles secassem"133. Os poetas trágicos apresentam homens, heróis e deuses em situação de descontrole emocional, dominados pelo riso ${ }^{134}$ ou chorando desesperados ${ }^{135}$. O poeta austero da República não deveria apresentar nada disso, nem poderia apresentar pessoas sofrendo demais com o luto ${ }^{136}$, nem dizer que o Hades, reino dos mortos, é terrível, pois isto desestimularia a coragem necessária aos cidadãos guerreiros ${ }^{137}$. Portanto, apesar de considerar Homero um grande poeta e o "primeiro entre os trágicos", e considerar que seus escritos são poéticos e o "povo gosta de ouvi-los”, Platão recomenda outro gênero de poeta para a República,

\footnotetext{
${ }^{131}$ A embriaguez é um dos perigos para a República, os guardiões devem afastar-se dela: "Mas a embriaguez é para os guardiões o que há de mais inadequado, e também a languidez e a ociosidade" (PLATÃO, REPÚBLICA, 398e, p. 106)

${ }^{132}$ Contra essa característica, o poeta da República deveria ensinar a submissão aos governantes e a moderação: “E, para a maioria dos homens, os pontos principais da moderação não são, de um lado, a submissão aos governantes, mas, de outro, o autodomínio sobre os prazeres da bebida, do amor e da comida?" (PLATÃO, REPÚBLICA, 389e, p. 92)

133 "E sobre os prazeres do sexo, sobre a impulsividade e todos os apetites da alma, não só os que nos dão prazer, mas também os que nos causam dor e, segundo dizemos, nos acompanham em todas as ações? Tais apetites decorrem da imitação poética? Ela os nutre e irriga, quando devia deixar que secassem, e dá-lhes o comando sobre nós, quando devia fazê-los submissos a nós para que nos tornemos melhores e mais felizes e não piores e mais infelizes." (PLATÃO, REPÚBLICA, 606d, p. 398)

134 “Ah! Não se deve admitir que apresentem em seus poemas, dominados pelo riso, homens que merecem nosso apreço e, muito menos, os deuses” (PLATÃO, REPÚBLICA, 389a, p. 91)

${ }^{135}$ O poeta da República, ao contrário, não mostrará deuses a chorar: "Mais do que isso! Nós lhes pediremos que não apresentem deuses a chorar e a dizer: 'Ai! Pobre de mim, pobre de mim, infeliz mãe de um herói!'” (PLATÃO, REPÚBLICA, 388c, p. 90)

${ }^{136}$ Em vez de mostrar sofrimento exagerado com o luto o poeta da República deveria seguir neste ponto a atitude que é considerada pelos cidadãos como mais adequada para os homens: "De outro lado, sabes que, ao inverso, quando ocorre para um de nós um luto em família, gabamo-nos da atitude oposta, se conseguimos manter a calma e resistir, porque é essa a atitude própria de um homem, e a outra, a que há pouco louvávamos, é própria de uma mulher" (PLATÃO, REPÚBLICA, 605e, p. 397).

${ }^{137}$ Mitos que desestimulam a coragem devem ser banidos: “- E então? Se alguém pensar que o Hades existe e é terrível, crês que ele será destemido em relação à morte e, nos combates, preferirá a morte à derrota e à escravidão? De forma alguma." (PLATÃO, REPÚBLICA, 386b, p. 87)
} 
e este deve ser ainda mais duro do que os poetas trágicos. De Homero deveriam ser salvos apenas "hinos aos deuses e encômios aos homens de bem"138.

Platão subordinou a poesia à sua República, e esta à sua metafísica. Por esse motivo, alguns comentadores consideram que Platão inaugurou a filosofia política, mas a tornou escrava da metafísica ${ }^{139}$. Em boa medida, seu pensamento possui traços semelhantes aos da posteriormente hegemônica tradição judaico-cristã, mas estava em antagonismo com grande parte da tradição grega. Platão queria expulsar "o legado homérico" da cidade (MACINTYRE, 2001, p. 226), substituir a política e a democracia pelo governo "técnico" de especialistas/filósofos, enquanto as tragédias reinterpretaram o legado homérico no mundo da cidade democrática.

\section{ARISTÓTELES E AS TRAGÉDIAS}

Aristóteles não estava tão separado da tradição hegemônica no mundo grego quanto o seu mestre, Platão. Em sua crítica à Platão, Aristóteles restabeleceu laços com a tradição grega, entre os quais devemos destacar: 1) A reabilitação da política e da pluralidade $^{140}$; 2) A retomada da ideia trágica acerca dos limites do conhecimento humano, com sua teoria da prudência

\footnotetext{
138 "Então Gláucon, falei eu, quando topares com admiradores de Homero que dizem que esse poeta é o educador da Grécia e, no que diz respeito a administração e educação, é humano e vale a pena, acolhendo-o e aprendendo com ele, viver a vida toda de acordo com esse poeta; e é preciso beijá-los e saudá-los como pessoas que são tão excelentes quanto possível e conceder que Homero é o melhor poeta e o primeiro entre os trágicos, mas saber que somente hinos aos deuses e encômios aos homens de bem devem ser admitidos na cidade. Se, porém, acolheres a sedutora musa na lírica ou na épica, o prazer e a dor reinarão na cidade em vez da lei e do princípio que, entre nós, sempre foi tido como o melhor" (PLATÃO, REPÚBLICA, 607a, p. 398) Grifos nossos.

139 "Eis o ponto central da questão: não houve, até agora, pensamento político verdadeiro. Houve, em alguns períodos da história, uma verdadeira atividade política e o pensamento implícito a essa atividade. Mas o pensamento político explícito foi apenas filosofia política, isto é, província da filosofia, subordinada a esta, escrava da metafísica, encadeada aos pressupostos não conscientes da filosofia e sobrecarregada de suas ambiguidades" (CASTRORIADIS, 2004).

${ }^{140}$ Aristóteles não pretendia eliminar a política e substituí-la por um governo "técnico", tampouco concordava com a eliminação da pluralidade, eliminação de qualquer particularismo, tal como defendia Platão: "É claro que se a imposição de unificação for além de certo ponto, já não haverá mais uma cidade, pois a cidade é por natureza uma pluralidade; se sua unificação avançar demasiadamente, a cidade será reduzida a uma família, e a família a uma individualidade, pois podemos dizer que a família é mais unida que a cidade, e o indivíduo mais uno que a família" (ARISTÓTELES, POLÍTICA, 1261b, p. 36) Grifos nossos.
} 
(phronesis) ${ }^{141}$ e 3) A reavaliação positiva da arte, que apesar de continuar sendo considerada inferior à filosofia, não recebia mais as criticas radicais que haviam sido feitas por Platão.

Aristóteles considerou a poesia superior à história. A poesia é imitação, mas não imita apenas "o que aconteceu”, como seria próprio da História. A diferença entre história e poesia não está na metrificação, mas no fato de que a poesia conta as coisas "que podiam acontecer, possíveis no ponto de vista da verossimilhança ou da necessidade", por esse motivo, "a poesia encerra mais filosofia e elevação do que a História; aquela enuncia verdades gerais; esta relata fatos particulares”. (ARISTÓTELES, POÉTICA, 2005, p. 28). Além desta consideração favorável à poesia, Aristóteles foi mais cuidadoso que Platão na análise da poesia. Enquanto Platão tratou a poesia apenas em sua filosofia política e o fez do ponto de vista do polemista e moralista, Aristóteles, em sua Poética, foi o primeiro filósofo a tratar da poesia de "uma maneira científica mais do que polêmica", foi o primeiro a tratar da poesia "nos seus próprios termos" (KAUFMANN, 1968. p. 32-3). Se Platão estava mais preocupado com o conteúdo do trágico e com isso diluiu as fronteiras entre a poesia épica e as tragédias, fazendo de Homero o "primeiro entre os trágicos", Aristóteles, por sua vez, concentrava-se na análise do gênero trágico, e com isso estabelece diferenças nítidas entre os gêneros da poesia épica, da comédia e da tragédia.

Para Aristóteles, como para Platão, a arte é imitação, mas essa característica já não desvaloriza tanto a arte em Aristóteles, visto que ele abandona a teoria das Ideias de seu mestre e

\footnotetext{
${ }^{141}$ Ao contrário de Platão, que imaginava ser possível um conhecimento exato (sofia) sobre as coisas humanas, Aristóteles considerava isso impossível, pois o mundo humano seria ainda mais marcado pela contingência que o mundo puramente físico, entretanto, existiria uma virtude intelectual que ajudaria o homem a se orientar nesse mundo: a prudência (phronesis), uma virtude intelectual capaz de medir, calcular, avaliar, as condições e meios de uma determinada situação e com isso orientar para a tomada da melhor decisão (mas a phronesis não nos diz nada sobre a melhor maneira de agir em todas as situações, como seria no caso dos juízos categóricos). A prudência nos ajuda a encontrar os meios necessários para atingirmos um fim, mas os fins não são propriamente produtos da escolha, pois são de origem natural ou criados pelo hábito, daí vem a conclusão de Aristóteles de que nós não deliberamos sobre os fins, mas apenas sobre os meios (ZINGANO, 2007, pp. 226-227; VERNANT, J.P. e NAQUET, P.V., 1981, p. 32). Ao apontar limites do conhecimento humano, Aristóteles se reaproxima da tradição popular e trágica grega (AUBENQUE, 2003, p. 247). Como já citamos anteriormente, os trechos da Ética sobre este ponto são: "o fim é, pois, objeto de desejo e os meios, objeto de deliberação e decisão" (ARISTÓTELES, ÉTICA, 1111 b26) e "O princípio da decisão é o desejo e o cálculo o que calcula os meios de obter um fim" (ARISTÓTELES, ÉTICA, 1139 a31).
} 
com isso a arte deixa de ser a imitação da imitação e passa a ser imitação de objetos, pessoas e ações reais, que não são mais considerados uma pálida imitação do mundo das ideias. Imitar é natural ao homem ${ }^{142}$ e os gêneros artísticos se diferenciam em virtude do que imitam e como imitam. Na poesia, a comédia é a imitação de pessoas inferiores e o cômico é uma espécie de feio. A poesia épica e as tragédias, por sua vez, imitam "seres superiores" em versos metrificados ${ }^{143}$. A diferença entre a épica e as tragédias está na multiplicidade de fábulas e na extensão da composição e do metro. Na poesia épica, a multiplicidade de fábulas e a extensão são maiores, enquanto as tragédias são mais econômicas e procuram se concentrar, tanto quanto possível, em "uma ação única", sendo considerada por esse motivo "superior à epopeia" (ARISTÓTELES, POÉTICA, 2005, p. 52). O metro épico é o "heroico", considerado por Aristóteles mais pausado e amplo e que permite uma "linguagem mais esmerada", enquanto nas tragédias prevalecem o metro jâmbico e o tetrâmetro, considerados "mais movimentados" e próprios para a dança, no primeiro caso, e para a ação, no segundo caso (ARISTÓTELES, POÉTICA, 2005, p. 47).

Estabelecidas essas diferenças básicas, passemos à sua definição formal de tragédia, que teve longa repercussão nas discussões sobre o gênero trágico, da antiguidade aos dias atuais.

\section{Escreveu Aristóteles:}

"É a tragédia a representação de uma ação grave, de alguma extensão e completa, em linguagem exornada, cada parte com o seu atavio adequado, com atores agindo, não narrando, a qual, inspirando pena [eleos] e temor [phobos], opera a catarse própria dessas emoções. Chamo linguagem exornada a que tem ritmo, melodia e canto; e

\footnotetext{
142 "Parece, de modo geral, darem origem à poesia duas causas, ambas naturais. Imitar é natural ao homem desde a infância - e nisso difere dos outros animais, em ser o mais capaz de imitar e de adquirir os primeiros conhecimentos por meio da imitação - e todos têm prazer em imitar (...) Por serem naturais em nós a tendência para a imitação, a melodia e o ritmo - que os metros são parte dos ritmos é fato evidente - primitivamente, os mais bem dotados para eles, progredindo a pouco e pouco, fizeram nascer de suas improvisações a poesia". (ARISTÓTELES, POÉTICA, IV, 2005, p. 21-22).

143 "A comédia, como dissemos, é imitação de pessoas inferiores; não, porém, com relação a todo vício, mas sim por ser cômico uma espécie do feio. A comicidade, com efeito, é um defeito e uma feiúra sem dor nem destruição; um exemplo óbvio é a máscara cômica, feia e contorcida, mas sem expressão de dor (...) A poesia épica emparelha-se com a tragédia em serem ambas imitação metrificada de seres superiores". (ARISTÓTELES, POÉTICA, V, 2005, p. 24)
} 
atavio adequado, o serem umas partes executadas com simples metrificação e as outras, cantadas". (ARISTÓTELES, 2005, p. 24).

Ao contrário da comédia, a tragédia representa (imita) uma ação grave. Mas além da representação dessa ação grave "em linguagem exornada" dar prazer, Aristóteles menciona características que atribuem à tragédia um papel na educação dos cidadãos, pois as encenações trágicas devem despertar pena ou compaixão (eleos, que Kaufmann prefere traduzir como simpatia) e temor (phobos), e operar "a catarse própria", adequada, destas emoções. É certo que catarse aqui não quer dizer eliminação desses sentimentos, como foi interpretado por alguns já na época cristã. O termo catarse possuía na época de Aristóteles dois usos, um deles tinha origem nos rituais religiosos e tinha sentido de purificação ou limpeza, o outro tinha origem nos conceitos médicos, e significava purgação (NUSSBAUM, 1994). De qualquer forma, não se trata de eliminar esses sentimentos, mas de "tratá-los", dando-lhes justa medida. Para Aristóteles, a catarse é esse tratamento, expõe esses sentimentos, mas afasta nos espectadores o excesso de medo (phobos) e de compaixão/simpatia (eleos), produzindo, além de moderação, alívio.

Na Política, quando escreve sobre a educação musical, Aristóteles também usa o termo catarse. Aristóteles divide as melodias em éticas, práticas e entusiásticas ${ }^{144}$. As éticas são importantes para a educação e representam as disposições estáveis do caráter, as práticas representam a ação e as entusiásticas representam distúrbios emocionais que produzem em quem as escuta "perturbações" como o medo e a compaixão, mas, ao mesmo tempo, essas melodias exercem um efeito sedativo, como um remédio para aqueles que tem “predisposição” emotiva:

“Essa predisposição a ser afetado pela música, tão intensa em certas pessoas, existe em todas elas, e só difere para menos ou para mais - por exemplo, a piedade, o temor e também o entusiasmo são manifestações dela; 144 "Já que aceitamos a classificação das melodias feita por alguns filósofos, ou seja, melodias de efeito ético, de
efeitos práticos e inspiradores de entusiasmo, distribuindo as várias harmonias entre estas classes de melodias como
sendo naturalmente afins a uma delas, diremos que o emprego da música não se limita a uma única espécie de
utilidade, e que, ao contrário deve haver muitas. Com efeito, ela pode servir à educação e à catarse - no momento
usamos 'catarse' sem maiores explicações, mas voltaremos a discutir mais claramente o significado que lhe
atribuímos - e em terceiro lugar ela serve de diversão, atuando como relaxante de nossas tensões e aliviando-as"
(ARISTÓTELES, POLÍTICA, 1342 a-b, p. 283-4) 
de fato, algumas pessoas são muito suscetíveis a estas formas de emoção, e sob a influência da música religiosa vemo-las, quando ouvem melodias que lhe excitam a alma, lançadas num estado semelhante ao dos doentes que encontram um remédio capaz de livrá-los de seus males; a mesma sensação devem experimentar as pessoas sob influência da piedade e do terror e as outras pessoas emotivas em geral, na proporção em que estas são suscetíveis a tais emoções, e todas devem passar por uma catarse e ter uma sensação agradável de alívio" (ARISTÓTELES, POLÍTICA, 1342b, p. 284)

A catarse trágica foi interpretada nos moldes da catarse musical e teria, portanto, um efeito sedativo, como tratamento médico ou purgação. Nietzsche discordou deste efeito sedativo, mas talvez seu exagero na crítica à Aristóteles se devesse a uma necessidade que Nietzsche tinha de se contrapor à apropriação que determinados autores franceses e alemães fizeram do estagirita, moralizando-o em excesso já a partir de pressupostos do mundo judaico-cristão, mas, com isso, Nietzsche perde de vista que a posição de Aristóteles também está na perspectiva da medida e não do remédio radical, que seria a eliminação ou neutralização dos sentimentos. De qualquer forma, a medida que Aristóteles vê como produto da catarse é descrita como um sedativo, e não como um tônico que faria o espectador sentir, para além do temor e da compaixão, o "eterno prazer do vir a ser", como entendia Nietzsche. Ora, mas sentir "eterno prazer no vir a ser" também não produz um "alívio"? Também não é uma "consolação metafísica", um remédio? Teríamos que indagar aqui sobre diferentes formas de alívio produzidos pela arte em Aristóteles e Nietzsche, uma que levaria a alma a estar como um mar calmo e outra como um mar revolto e pleno de aventuras e possibilidades, mas essas especulações fogem ao foco deste trabalho. Para nossos propósitos, queremos apenas mostrar que Aristóteles não entende as tragédias do ponto de vista do moralista, o que aparece claramente na ausência de maniqueismo na sua análise da peripécia das tragédias e da queda do herói como fruto de um erro (hamartia).

Toda tragédia, diz Aristóteles, deve ter começo, meio e fim, e nas tramas complexas deve 
ter possuir peripécia - uma "viravolta das ações em sentido contrário" - e reconhecimento - a "mudança do desconhecimento ao conhecimento, ou à amizade, ou ao ódio, das pessoas marcadas para a ventura ou a desdita”. Para Aristóteles, “O mais belo reconhecimento é o que se dá ao mesmo tempo que uma peripécia, como aconteceu no Édipo" (ARISTÓTELES, POÉTICA, 2005, p. 30). Nas melhores tragédias, a mudança de fortuna não provém da maldade, mas de um erro (hamartia), entendido em sentido não moral, e o herói não pode ser alguém nem muito bom nem muito mau:

"Resta o herói em uma situação intermediária; é aquele que nem sobreleva pela virtude e justiça, nem cai no infortúnio em consequência de vício e maldade, senão de algum erro [hamartia], figurando entre aqueles que desfrutam grande prestígio e prosperidade; por exemplo, Édipo, Tiestes e homens famosos de famílias como essas. Necessariamente, pois, deve a fábula bem sucedida ser singela e não, como pretendem alguns, desdobrada; passar, não do infortúnio à felicidade, mas, ao contrário, da felicidade a infortúnio que resulte, não de maldade, mas dum grave erro de herói como os mencionados, ou dum melhor antes que dum pior” (ARISTÓTELES, POÉTICA, 2005, p. 32)

Além de não ser verossímil alguém totalmente mau ou totalmente bom, restando o "herói em situação intermediária”, Aristóteles pensa que a emoção trágica não seria despertada com a queda de um herói muito malvado que escolheu "de bom grado", isto é, sem coerção externa, praticar as ações que o levaram ao infortúnio. Nesse caso, o que se provoca nos espectadores é a sensação de castigo merecido. Por esse motivo, Aristóteles critica Eurípides por ter apresentado um Menelau excessivamente malvado em sua peça Orestes. Porém, quando o herói é "intermediário" como os espectadores, é admirado como um grande homem, e vai da felicidade ao infortúnio em virtude de um "erro" (hamartia, que pode ser fruto de ignorância das circunstâncias, da arrogância, das paixões ou do engano operado por um deus), nesse caso, produz-se emoção trágica e "sentimentos de humanidade" 145.

\footnotetext{
145 “É, porém, nas peripécias e nas ações singelas que os poetas acertam admiravelmente no alvo, que é obter a emoção trágica e os sentimentos de humanidade" (ARISTÓTELES, POÉTICA, 2005, p. 39)
} 
A ausência de maniqueismo e de um ponto de vista moral categórico também aparece no modo como Aristóteles pensa que devemos julgar as ações do herói. Ao contrário do ponto de vista categórico, que julga as ações dos heróis a partir de uma moral universal válida para qualquer situação, Aristóteles, defende que em vez de julgarmos apenas "o ato em si”, devemos sempre levar em conta o contexto, o personagem que fala e a finalidade da ação, aceitando que se faça algo errado "para deparar um benefício maior" ou "prevenir maior malefício":

“Para examinar se alguma personagem disse ou fez alguma coisa bem ou não, devemos não só considerar se é nobre ou vil em si o ato ou a palavra, mas também levar em conta a personagem que age ou fala, a quem o faz, quando, por quem ou para que; por exemplo, a fim de deparar um benefício maior, ou prevenir maior malefício”. (ARISTÓTELES, POÉTICA, 2005, p. 49).

Portanto, Aristóteles continua vendo a culpa dos heróis trágicos como a "pequena pedra na qual tropeçam"146, culpa em virtude de erros que qualquer homem pode cometer e que o levam ao infortúnio, em vez de tentar enxergar em toda queda um castigo por um grave erro moral. As encenações trágicas, ao operarem a catarse do medo e da compaixão e criarem "sentimentos de humanidade", eram saudáveis para a Polis. Em vez de expulsar os poetas trágicos da polis e substituí-los pelo poeta oficial da República, como queria Platão, Aristóteles defende as tragédias e seu papel para a saúde da polis. É como se para Aristóteles a solução de Platão fosse agravar a desmedida dos sentimentos, porque sua "poesia austera" não oferecia válvula de escape aos sentimentos e paixões e exigia dos cidadãos uma sobriedade inumana.

Entretanto, assim como Platão, Aristóteles preocupa-se com a unidade da polis, ameaçada pela irrupção da hybris e da stasis e também entende o papel da pleonexia como motor da stasis $^{147}$. Sua solução, porém, não passa pela tentativa de suplantar a pleonexia por meio do 146 “A culpa de seus heróis trágicos é a pequena pedra na qual tropeçam e, por isso, quebram o braço ou arrancam
um olho: a sensibilidade antiga comentava sobre isso: 'Sim, ele deveria ter seguido sua estrada com mais cautela e
menos petulância!' Mas apenas ao cristianismo estava reservado dizer: 'Eis uma grave infelicidade, e por trás dela
tem de se esconder uma culpa grave, igualmente grave, ainda que não a vejamos claramente!' (...) Na Antiguidade
ainda havia realmente infelicidade, pura, inocente infelicidade; apenas no cristianismo tudo se torna castigo, punição
bem merecida" (NIETZSCHE, 1881, aforismo 78, p. 62-3)
${ }_{147}$ Pleonexia como desejo sem limites: "A igualização das propriedades entre os cidadãos é sem dúvida um dos 
governo "técnico" dos filósofos, mas envolve direcioná-la ou discipliná-la por meio de uma constituição mista de classes sociais, governo da lei e uma polis sem grandes desigualdades, que mantenha a maioria da população na "classe média" (ARISTÓTELES, POLÍTICA, 1295b1296a, p. 331). Nesse projeto, as peças trágicas tem seu papel na formação adequada das vontades por meio da catarse, o que significa uma estilização dos instintos e sentimentos que evitem a hybris. Alguns, como Page duBois, defenderam que Aristóteles oferece uma visão sobre as tragédias da "perspectiva do poder", pois vê nas tragédias um meio para disciplinar o corpo social e evitar a desordem ${ }^{148}$. A posição de duBois, entretanto, pressupõe que não seja nem necessário nem desejável disciplinar, uma posição que só emerge muito tempo depois da consolidação do "modo estatista de governar". Para aqueles que não contavam com esse modo, como os cidadãos, políticos, poetas e filósofos das cidades-estado, de algum modo é preciso educar para a liberdade, "estilizar" as vontades, por isso tanto os filósofos quanto os poetas trágicos entendiam-se como pedagogos, permanecendo a querela a respeito de qual seria a melhor pedagogia.

\footnotetext{
fatores suscetíveis de contribuir para evitar revoluções; não é, porém, um dos mais importantes, pois os membros das classes superiores se ressentiriam, argumentando que seus méritos não são iguais aos dos componentes das classes inferiores; por isto os vemos com frequência atacando o governo e rebelando-se; também a cupidez humana é insaciável, e embora inicialmente um subsídio de dois óbolos fosse bastante, quando este se tornou um direito adquirido as pessoas passaram a querer cada vez mais, sem nunca chegarem a um limite (o desejo por sua própria natureza não tem limites, e a maioria dos homens vive para sua satisfação)" (ARISTÓTELES, POLÍTICA, 1267b, p. 53). Grifos nossos.

148 "His views on catharsis, for example, refer to a disciplining of the social body, directing the reader's attention from the collective towards the individual member of the audience, who experiences a catharsis of pity and fear. The philosopher offers a view of tragedy from the perspective of power, administration, and the cultivation of individual contentment. He assumes a view from above and outside the city, concerned with identifying systems that prevent social disruption and disorder, where tragedy is useful, contra the view of Plato, precisely because it displaces unruly emotion into the realm of art in order to maintain order in the state. Tragedy becomes a site of mastery for the philosopher, who is a manager, analyst, and theoretician of the state and its elite members" (DUBOIS, 2008, p. 132)
} 


\section{CAPÍTULO 3 - A DISPUTA POR MAQUIAVEL}

É preciso ter certa inclinação agonística para se aventurar no debate acadêmico em torno de Maquiavel, em razão da disputa intensa entre correntes diferentes acerca do significado de sua obra. Nos últimos trinta anos, os autores ligados à Cambridge School tem vencido a luta nesta arena que é a obra de Maquiavel. O chamado "contextualismo linguístico" desenvolvido por essa escola permitiu matizar conceitos que pareciam "naturalizados" e que eram tratados de maneira quase intercambiável. A contextualização, o rigor no trabalho com as fontes e com a reconstrução discursiva, permitiram um distanciamento em relação às interpretações anacrônicas e consideradas intocáveis, por servirem aos propósitos de legitimação de uma história vencedora que culminava na democracia liberal representativa. $\mathrm{O}$ método permitiu a reabertura dos conceitos e a reflexão sobre a tensão entre republicanismo e liberalismo, democracia e república, democracia e liberalismo. Esta abertura na história da ideias, permitiu uma abertura em relação ao presente, possibilitando a reflexão crítica sobre as questões políticas da atualidade. Não é à toa que a discussão sobre o republicanismo florentino tenha repercutido no debate da teoria política contemporânea, especialmente entre comunitaristas e individualistas nos EUA.

Hans Baron foi uma referência para Pocock, Skinner e demais pesquisadores da chamada "Cambridge School"149. A obra de Baron sobre o Renascimento italiano renovou os estudos renascentistas, ao adicionar rigor histórico e relacionar a emergência do humanismo com o contexto político da Itália renascentista. Baron recuperou a interpretação republicana da obra de Maquiavel, que já tinha longa história - tendo entre seus defensores nomes como James Harrington e Jean Jacques Rousseau -, mas que nunca havia se tornado hegemônica, pois

\footnotetext{
149 Pocock não lecionava em Cambridge, mas fez seu PhD nesta universidade em 1952. Foi professor da John Hopkins University desde 1975, ano da publicação de Machiavellian Moment. Apesar de não lecionar em Cambridge, é comum considerá-lo como membro da "Cambridge School" em virtude de afinidades na metodologia e nos temas pesquisados, que formam uma escola distinta de outras tendências acadêmicas no campo da história das ideias.
} 
prevalecia a interpretação que reduzia Maquiavel ao "maquiavelismo" e entendia o florentino como conselheiro de tiranos e não como republicano.

Baron usou a expressão "humanismo cívico" (BARON, 1960, p. 448) para se referir ao republicanismo da Itália renascentista. Para Baron, o humanismo cívico resultou de um "processo gradual de fusão entre o humanismo", que era mais um movimento literário, com o "ponto de vista cívico" (BARON, 1961, p. 6). Esse processo ocorreu no contexto de mobilização das cidades-estado republicanas contra a expansão das "tiranias" do norte da Itália, especialmente de Milão. Baron apresentou Florença e Veneza como postos avançados de luta pela liberdade em uma era que se movia inexoravelmente para o absolutismo. Estas cidadesestado preservaram os ideais políticos clássicos - de liberdade, vida ativa, autogoverno -, que seriam herdados nos tempos modernos pelas democracias ocidentais. Assim, Baron teria mostrado a continuidade de uma tradição que vai da Grécia clássica até as modernas democracias liberais.

Entretanto, a inserção de Maquiavel no humanismo cívico não foi sem problemas. Nos seus trabalhos da década de 1930, Baron entendia Maquiavel como um crítico que estava em antagonismo com o humanismo cívico. Na década de 50, em que publicou seu trabalho mais famoso, The Crisis of the Early Italian Renaissance, Baron refaz seu Maquiavel, tornando-o mais um membro do humanismo cívico. Neste livro, Baron critica a tese dos que viam Maquiavel como um "conselheiro de príncipes" e não um autor republicano. Entretanto, Maquiavel terá um lugar marginal no livro de Baron, que não superou ou neutralizou sua abordagem anterior que entendia Maquiavel em antagonismo com o humanismo cívico (NAJEMY, 1996, p. 121-2). Para Najemy, The Crisis, contém as duas visões de Baron sobre Maquiavel, sem reconciliá-las (NAJEMY, 1996, p. 124). O que evidencia a dificuldade de incluir Maquiavel, sem mais, na tradição do humanismo cívico. 
Mas o próprio conceito de humanismo cívico de Baron passou a ser contestado. Para Najemy, o humanismo cívico não foi uma defesa da república contra a monarquia, nem uma ideologia forjada na luta contra Milão. O humanismo cívico foi uma ideologia (não em sentido manipulatório) que resultou do conflito interno da sociedade florentina (NAJEMY, 2000). Duas formas muito diferentes de republicanismo confrontavam-se naquele momento e o humanismo cívico foi a expressão intelectual e ideológica da ascendência e triunfo de uma nova forma de republicanismo florentino. Para Najemy, o real antagonista do humanismo cívico era o republicanismo popular de guildas, que periodicamente aparecia para mudar a hegemonia da elite nos séculos 13 e 14. Enquanto o republicanismo de guildas criou uma forma de governo “corporativa" que representava interesses, promoveu uma participação política cada vez mais ampla e tinha entre seus defensores setores das classes populares, o humanismo cívico, por sua vez, encontrava sua principal audiência entre aristocratas e altos funcionários públicos, rejeitava o governo de guildas, defendia uma participação política restrita, rejeitava categoricamente o conflito social (reforçando o ideal de harmonia e unidade cívica), era contrário à representação de interesses e tinha a ideia de que o bom cidadão nunca representa interesses ou pertence a um grupo (NAJEMY, 2000, p. 92).

Para Najemy, Baron não tirou as últimas consequências sobre a crítica que Maquiavel fez a Bruni e Poggio, no proêmio da sua História de Florença, por terem ignorado ou reduzido à insignificância a longa experiência de discórdia civil na cidade (NAJEMY, 1996, p. 126). Segundo Najemy, ao fazer essa crítica e ao especular que o medo de ofender os poderosos motivava a maneira deles escreverem história, Maquiavel estava dizendo que as ideias dos humanistas cívicos eram estrategicamente pensadas para legitimar a oligarquia governante. Para Najemy, Maquiavel não fez essa crítica por ser menos republicano que os humanistas cívicos, mas por terem diferentes noções sobre o papel dos intelectuais na política e sobre o que constitui 
uma república saudável. Ao não levar às últimas consequências as críticas de Maquiavel aos humanistas cívicos, Baron não percebeu o "ensinamento mais revolucionário entre todas as ideias políticas de Maquiavel": que a liberdade só pode florescer onde a competição entre classes é permitida e até mesmo encorajada pelas leis, instituições e pelos intelectuais" ${ }^{150}$.

Hans Baron, em um artigo de 1961 (segundo Najemy, a mais importante contribuição de Baron para os estudos de Maquiavel), escreve que Maquiavel buscava as fontes do poder político na "fábrica social e constitucional que estimulava as energias cívicas e o espírito de sacrifício e devoção em todas as classes do povo" "151. Para Najemy, os termos "devoção e sacrifício" são similares aos que Baron utilizava em seus trabalhos da década de 1930 para caracterizar o humanismo cívico, mas nestes trabalhos, Baron dizia que Maquiavel não acreditava nesse espírito de devoção e sacrifício. Najemy defende que a "pureza ética dos objetivos políticos", sempre foi um componente crucial da compreensão de Baron a respeito do humanismo cívico, e, para incluir Maquiavel nesta tradição, Baron precisou converter Maquiavel em alguém que compartilhava dessa confiança e otimismo a respeito dos seus compatriotas e acreditava na possibilidade da "devoção e sacrifício em todas as classes do povo" (NAJEMY, 1996, p. 127). Para Najemy, se a abordagem de Baron teve o mérito de afastar Maquiavel da interpretação que o reduzia ao "maquiavelismo", por outro lado, Baron perde aspectos essenciais e originais da obra de Maquiavel, entre eles a ênfase no conflito social, sua polêmica dura contra as aristocracias, o uso instrumental da religião e as ambições hegemônicas que Maquiavel via como centrais na política republicana ${ }^{152}$. A crítica de Najemy encontra uma característica em Baron que 150 "Implicitly, Machiavelli saw the ideas of the civic humanists as ideology as a strategically pursued legitimation of
the hegemony of the ruling group. He offered this critique, not because he considered republicanism irrelevant or a
lost cause but because he had different notions both of the role of intellectuals in politics and of what constituted a
healthy republic: notions built around the revolutionary idea - the most revolutionary of all Machiavelli's political
ideas - that liberty can flourish only where political competition between social classes is permitted and even
encouraged by law, institutions, and, not least, by intellectuals" (NAJEMY, 1996, p. 126).
151 "Although the central problem for Machiavelli remained that of the winning and defense of political power, the
sources were no longer sought in diplomatic craftsmanship exclusively, but in the first place in a social and
constitutional fabric that allowed the civic energies and a spirit of political devotion and sacrifice to develop in all
classes of a people" (BARON, 1961, p. 249).
152 "My guess is that this "ethical purity of political aims" was always a crucial component of Baron's understanding 
reaparecerá nos seus futuros seguidores da escola de Cambridge: na ânsia de livrar Maquiavel do "maquiavelismo" e inseri-lo na tradição republicana, tornaram o florentino palatável demais aos contemporâneos dos intérpretes e perderam de vista a originalidade de Maquiavel em relação ao seu próprio contexto humanista cívico $^{153}$. Esse tipo de abordagem tende a negligenciar que Maquiavel foi um partidário daquilo que Araújo chamou de "constituição mista plebeia", em contraste com a visão de constituição mista tradicional dos humanistas cívicos ${ }^{154}$. Também Leo Strauss notou o plebeísmo de Maquiavel, ainda que o tom de Strauss seja crítico em relação a esse aspecto, pois ele se posiciona do lado da "grande tradição"155.

Vinte anos após a publicação do livro de Baron em língua inglesa, Pocock publicou "The Maquiavellian Moment", trabalho que foi inspirado em parte no trabalho de Baron e na sua

of civic humanism and, indeed, the foundation of his judgment of intellectuals of any age. To bring Machiavelli into the long history of civic humanism, Baron needed to convert him to an "ethical purity" of trust and optimism in his fellow citizens and to the possibility of "devotion and sacrifice ... in all classes of a people." This was no doubt an important corrective to the image of Machiavelli that Baron inherited from his teachers and from the nineteenth century's insistence on the cold pragmatism and ruthless methods traditionally associated with Machiavelli. This conversion also meant, of course, that some essential features of Machiavelli's analysis of republics were lost from Baron's view: most important, the emphasis on social conflict and the necessity of political dissent, but also the harsh polemic against aristocracies (including that of republican Venice), the predatory nature of popular republics, the manipulation of ritual in the creation (among the Romans at least) of the indispensable religious undergirding of the very virtues of "devotion and sacrifice," and the social and military conditions of the periodic slide of republics toward factionalism and corruption. The remaking of Machiavelli made it difficult for Baron to acknowledge the elements of social conflict, ideological manipulation, and hegemonic ambition that Machiavelli himself saw as central to republican politics" ((NAJEMY, 1996, p. 127-8).

${ }^{153} \mathrm{O}$ tom crítico em relação à visão do humanismo cívico inaugurada por Baron é predominante no livro de ensaios Renaissance Civic Humanism, editado por James Hankins (HANKINS, 2000). Para William J. Connel, os esforços de Baron, Pocock e Skinner para assimilar Maquiavel na tradição cívico humanista tornaram-se cada vez mais problemáticos nos anos recentes. A tese de uma tradição republicana contínua que vai de Aristóteles à Jefferson, passando por Maquiavel, enfrentou numerosos ataques de historiadores do pensamento político que enfatizam as diferenças entre os autores desta suposta tradição no que diz respeito à participação e a uma análise da natureza humana (CONNEL, 2000). Essa posição de Connel expressa o tom geral da coletânea, o que revela sinais de desgaste da "Cambridge School".

${ }_{154}$ "Tendo em conta essa possibilidade mais ampla, diferencio uma versão 'aristocrática' e uma versão 'plebeia' da Constituição Mista. Na tradição da Antiguidade clássica, praticamente não encontramos uma defesa da última, dada a recepção positiva da ideia de uma hierarquia fixa de status entre as ordens sociais, presente em quase todos os autores clássicos que chegaram até nós. Mas penso que o pensamento clássico moderno, quando glosou a teoria da Constituição Mista tradicional, abriu-se à ideia de uma versão plebeia, especialmente a partir de Maquiavel, que a desenvolveu na perspectiva da desejabilidade do conflito social aberto no interior da comunidade política" (ARAÚJO, 2006, p. 243)

155 "It may easily appear that Machiavelli was the first philosopher who questioned in the name of the multitude or of democracy the aristocratic prejudice or the aristocratic premise which informed classical philosophy (...) But this bias in favor of the multitude enabled or compelled him not to identify himself simply with the aristocratic or oligarchic republicanism of the classical tradition (...) It is no accident, I believe, that the most shocking or the most 'Machiavellian' passage of the Florentine Histories is the speech addressed by a Florentine plebeian ins the year 1378 to the Florentine plebs". (STRAUSS, 1958, p. 127) 
tentativa de encontrar continuidades no pensamento político da Grécia até os pais fundadores dos EUA. De acordo com Pocock, o humanismo cívico foi uma corrente política distinta que passou da renascença florentina para Oliver Cromwell e daí para a América Colonial, onde se formou a base teórica da revolução americana. Dessa forma, o trabalho de Pocock liberou uma geração de historiadores americanos e teóricos políticos da ideia, até então inquestionável, de que a filosofia da revolução americana descendia diretamente da tradição liberal iniciada por John Locke, pelos contratualistas do séc. XVII e os teóricos do direito.

Segundo Pocock, os humanistas cívicos entendiam o homem como zoon politikon e a participação política seria o meio de exercitar a virtude e a razão e realizar a natureza humana (POCOCK, 1975, p. 98). A República seria uma "estrutura virtuosa" que promoveria a capacidade de cada cidadão colocar o bem comum acima do seu próprio (POCOCK, 1975, p. 184-5). Essa estrutura virtuosa seria mais do que um "estrutura dos costumes", visto que esta "segunda natureza" é fruto das circunstâncias e do tempo e estaria mais facilmente sujeita à corrupção. A estrutura da virtude, por sua vez, é fruto da atividade do legislador, e trabalha a matéria formada pela "estrutura dos costumes", de modo a reforçar os bons costumes e a virtude. O poder de modificar a "segunda natureza" não é ilimitado, porém possível e necessário para prolongar a vida da República e estimular a virtude dos cidadãos (POCOCK, 1975, p. 208). A virtù é a capacidade de impor forma sobre a Fortuna (POCOCK, 1975, p. 136), habilidade necessária ao legislador e aos cidadãos em um autêntico autogoverno. Os humanistas cívicos, incluindo Maquiavel, seriam continuadores da tradição aristotélica, com sua concepção de "vida boa", uma tradição distinta tanto da política baseada na teologia dos escolásticos, quanto do moderno liberalismo e socialismo. Pocock reconhece a proximidade entre seu trabalho e o de Hannah Arendt, pois ambos recuperam o ideal antigo do homo politicus, o zoon politikon de Aristóteles (POCOCK, 1975, p. 550), ideal que, para usar os termos de Benjamin Constant, 
retomados por Isaiah Berlin, representa uma concepção positiva de liberdade (BERLIN, 2002a).

A posição de Pocock ainda devia muito ao pressuposto de que o sucesso da república dependeria do espírito de "devoção e sacrifício" dos cidadãos ${ }^{156}$. Pocock, nesse ponto, segue a trilha de Baron. Mas em que medida a dedicação do cidadão antigo à sua polis significava pura abnegação? O que significava a glória nesse contexto? Pocock entende que a contradição entre bem comum e bem particular continuou sem solução na renascença, mas a voz preponderante era em favor do modelo "espartano" de "sacrifício" de "qualquer forma particular de autodesenvolvimento" (POCOCK, 1975, p. 74), modelo que também havia sido preferido por Platão. Segundo Pocock, no outro modelo disponível, preferido por Aristóteles, o cidadão era pensado como um ateniense "cuja diversidade de objetivos particulares fortalecia sua capacidade para agir no interesse público" (POCOCK, 1975, p. 74), embora a fórmula não pareça muito clara nesse trecho, Pocock quer dizer que Aristóteles não tentou eliminar o particularismo ${ }^{157}$. De qualquer forma, mesmo nesse modelo "ateniense", não é exatamente a ideia de mobilizar paixão contra paixão que emerge, ideia que já aparecia no agonismo dos "trágicos" antigos, e que não necessariamente teria que assumir a forma que assumiu na doutrina liberal dos "interesses", tal como Hirschman a expôs em seu livro As Paixões e os Interesses.

$\mathrm{Na}$ mesma época em que Pocock escrevia seu livro Machiavellian Moment, Albert Hirschman escrevia As Paixões e os Interesses, livro em que Maquiavel é situado entre os precursores da linha de raciocínio de lançar "paixões contra paixões" (HIRSCHMAN, 1977, p. 54), contra a "doutrina clássica" de suprimir as paixões e os apetites em virtude de seus efeitos negativos, doutrina que também tinha sua versão religiosa que mobilizava contra as paixões a “exortação moralista ou da ameaça de condenação eterna” (HIRSCHMAN, 1977, p. 37).

\footnotetext{
${ }^{156}$ Ideia que, como tentamos mostrar, Baron considerou central no humanismo cívico e que, segundo Najemy, constituía uma das diferenças entre o aristocrático humanismo cívico e o republicanismo popular de guildas, que reconhecia uma representação de interesses.

157 "Aristotle did not think that individuals as citizen, engaged in the universal activity of pursuing and distributing the common good, should be considered out of relation with the same individual engaged in the particular activity of pursuing and enjoying the particular goods he preferred". (POCOCK, 1975, p. 68)
} 
Maquiavel teria dado o primeiro passo, ao distinguir "a verdade efetiva das coisas" das "repúblicas imaginárias que nunca foram vistas", e ter percebido que "uma teoria realista do Estado exigia um conhecimento da natureza humana", entretanto, para Hirschman, "suas observações a respeito desse assunto, embora invariavelmente perspicazes, são dispersas e não sistemáticas" (HIRSCHMAN, 1977, p. 34). Depois do florentino vieram Hobbes, Espinosa, Hume, Montesquieu, Adam Smith e os Federalistas, e, segundo Hirschman, todos eles teriam uma teoria da natureza humana que entendia o homem como um ser movido fundamentalmente pela paixão - entendida em termos genéricos que englobam diversos desejos e afetos - e que, diante das paixões, a razão seria inefetiva.

Para eles, portanto, tratava-se de "aproveitar as paixões, em vez de simplesmente reprimilas" (HIRSCHMAN, 1977, p. 38). A partir dessa reflexão teria surgido, com Bacon e Espinosa, a noção de "paixão compensatória", a ideia de que "só uma afeição pode se opor à outra" (Bacon), ou "um afeto só pode ser detido ou eliminado por um afeto contrário e mais forte" (Espinosa). Essa ideia passa por Hume, Hobbes, Montesquieu, Adam Smith e chega aos federalistas ${ }^{158}$. Segundo Hirschman, a ideia de paixão compensatória só podia surgir depois de uma "declaração de independência dos preceitos e regras moralistas que tinham sido o principal apoio da filosofia política pré-maquiavélica” (HIRSCHMAN, 1977, p. 55). O que Hirschman não menciona é que a ideia de mobilizar vontade contra vontade já estava presente na cultura trágica antiga, como tentamos mostrar no capítulo anterior, cultura trágica que havia sido alvo de crítica da então nascente (desde Platão) filosofia política "moralista" e "pré-maquiavélica”. Quer dizer, há um

\footnotetext{
158 "Ambition must be made to counteract ambition. The interest of the man must be connected with the constitutional rights of the place. It may be a reflection on human nature, that such devices should be necessary to control the abuses of government. But what is government itself, but the greatest of all reflections on human nature? If men were angels, no government would be necessary. If angels were to govern men, neither external nor internal controls on government would be necessary. In framing a government which is to be administered by men over men, the great difficulty lies in this: you must first enable the government to control the governed; and in the next place oblige it to control itself. A dependence on the people is, no doubt, the primary control on the government; but experience has taught mankind the necessity of auxiliary precautions". Grifos nossos. Madison, J. Federalist Papers, 51.
} 
intervalo entre o pré-teleológico e o pós-teleológico, formado pela filosofia metafísica e pela tradição bíblica, que não foi mencionado por Hirschman.

Hirschman reconstrói a história da seleção de um gênero de paixão compensatória, o interesse, isto é "uma compreensão disciplinada daquilo que é necessário para promover o poder, a influência e a riqueza de alguém" e acrescenta que o interesse foi "sendo reduzido, por algum processo, para a busca da vantagem material, econômica" (HIRSCHMAN, 1977, p. 59). Nesse processo, o interesse passou a ser visto como "a paixão do amor-próprio melhorada e contida pela razão, e como razão que recebe orientação e força daquela paixão" (HIRSCHMAN, 1977, p. 65). Em seguida, o interesse começou a ser entendido como distinto e oposto às paixões. Logo, o mundo governado pelo interesse foi considerado como capaz de oferecer mais previsibilidade e constância, o enriquecimento foi considerado uma paixão "tranquila" e o "doce comércio" foi visto como criador de uma Era de paz (HIRSCHMAN, 1977, p. 83).

Hirschman chega a escrever que a ideia de paixão compensatória, quando formulada por Montesquieu pela primeira vez, estava ligada à busca de glória, e não com o "desejo de dinheiro":

"Na verdade a ideia de uma 'Mão Invisível' - e de uma força que faz com que os homens que buscam realizar suas paixões particulares conspirem inadvertidamente contra o bem público - foi formulada em conexão com a busca de glória, e não com o desejo pelo dinheiro, por Montesquieu. A busca pela honra numa monarquia, como diz ele, 'traz vida para todas as partes do corpo político'; como consequência, 'acontece que todos contribuem para o bem-estar geral enquanto pensam estar trabalhando pelos seus próprios interesses'” (HIRSCHMAN, 1977, p. 32)

Entretanto, Hirschman dedica menos de três páginas para "a ideia de glória e sua derrocada" e no seu comentário sobre a glória não há uma palavra sobre o mundo antigo. Ficamos assim sem saber nada sobre este outro gênero de paixão compensatória e Hirschman não cria espaço para pensarmos em outros desenvolvimentos possíveis depois da queda do 
“moralismo pré-maquiavélico", que não aquele que leva ao liberalismo, nem é levantada a possibilidade de mobilizar uma paixão compensatória, a "glória", contra outra paixão compensatória o "interesse", mantendo-as num equilíbrio tenso, um duelo entre "república" e "mercado", até porque não haveria necessidade, já que o interesse por si só produziria previsibilidade, constância, doçura, paz. Não é difícil imaginar quais são os impulsos por traz destas preferências, é o próprio Hirschman que nos diz que as atividades econômicas foram vistas com mais benevolência porque elas exprimiam "um desejo de descanso da grandeza"159 (HIRSCHMAN, 1977, p. 79).

Hirschman afirma, em prefácio de 1976, que Pocock teria sido um crítico em potencial de seu livro, mas que infelizmente ainda não havia lido Machiavellian Moment quando escreveu seu livro e pede desculpas a Pocock por essa negligência já que ambos "abordavam repetidamente tópicos estreitamente relacionados", ainda neste prefácio, Hirschman agradece "as conversas com Quentin Skinner em 1974-5”, que teriam sido proveitosas para o seu trabalho (HIRSCHMAN, 1977, p. 23).

Para Quentin Skinner, os teóricos republicanos da renascença não promoveram a participação na política como um modo de realização da natureza humana. Skinner considera que os teóricos da renascença, incluindo Maquiavel, defenderam uma cidadania ativa, não como um "bem primário", como queria Pocock, mas porque ela contribui para a manutenção da liberdade negativa. A liberdade positiva seria instrumental para defender a liberdade negativa. Skinner não procurava mais as raízes do republicanismo renascentista em Aristóteles, mas preferiu buscá-las em escritores romanos como Cícero, Salústio e Sêneca ${ }^{160}$. A ênfase de Skinner

\footnotetext{
${ }^{159}$ Cabe fazer um contraponto com outro autor que também rompeu com o "moralismo pré-maquiavélico" e também pensava em termos de paixão compensatória: Nietzsche, que, como vimos anteriormente, disse sobre a doutrina do interesse, "só um inglês consegue acreditar nisso"; sobre o desejo de descanso, "décadence"; sobre o individualismo, "é o grau mais modesto da vontade de poder".

${ }^{160}$ Essa posição de Skinner que estabelece uma diferença nítida entre autores gregos e romanos tem sido criticada. William Walker aponta as semelhanças entre Aristóteles e Salústio em relação ao conceito de liberdade civil (WALKER, 2006). Walker, a partir de uma leitura cuidadosa da obra de Salústio, acusa Skinner e Pettit de simplificar seu pensamento: "Like other grand narratives of western intellectual history, those offered by Skinner
} 
nas fontes romanas do humanismo cívico o levou a mudar sua terminologia e a preferir usar o termo "neo-romano" em vez de "republicano clássico"161.

Segundo Skinner, a concepção republicana de liberdade seria uma "terceira força" (SKINNER, 1990a, p. 308) capaz de resolver a oposição que MacIntyre julgava ser "a oposição moral crucial", que seria aquela entre o "individualismo liberal, em uma versão ou outra", associado às concepções negativas de liberdade, e a "tradição aristotélica, em uma versão ou outra", ligada às concepções positivas de liberdade. Para Skinner, essa oposição estabelecida por MacIntyre era falsa (SKINNER, 1990a, p. 293). A liberdade republicana como uma "terceira força" estaria representada em Maquiavel e nos outros escritores neo-romanos. Estes escritores seriam céticos em relação aos pressupostos essencialistas da concepção aristotélica acerca do caráter naturalmente social e político do homem ${ }^{162}$ e entenderiam a importância das leis e da religião para estimular a virtude nos cidadãos, forjando neles a noção de dever e a participação

and Pettit oversimplify the material in important ways and stand in need of qualification" (WALKER, 2006, p. 239), com isso teriam deixado de notar, por exemplo, que mesmo em Roma havia mais de uma visão sobre a liberdade: "But Sallust's ideal of liberty is in fact radically different from that of Cicero and the Roman nobles" (WALKER, 2006, p. 255). Depois de mostrar as afinidades entre Salústio e Aristóteles, Walker aponta algumas diferenças, entre elas, a valorização da glória pelo romano: "On the one hand, Sallust differs from Aristotle in emphasizing that the life of virtue is not the final end of man but is to be lived for the sake of that noble memory the Romans called gloria" (WALKER, 2006, p. 256-7). Walker não menciona (porque não era seu objetivo), que essa valorização da glória constitui um forte aspecto comum da cultura "popular" (não filosófica) tanto dos gregos quanto dos romanos antigos, cultura que, como tentamos mostrar, forneceu elementos para o ponto de vista trágico. Ricardo Silva mencionou este trabalho de Walker (SILVA, 2010, p. 55).

${ }^{161} \mathrm{O}$ termo devia muito a Hans Baron. Skinner também criticou Hans Baron por subestimar a continuidade entre o humanismo cívico e o legado das cidades-estado medievais (SKINNER, 2000, p. 93) e por Baron dedicar-se apenas a analisar causas "externas" (guerra contra Milão) para explicar o surgimento do humanismo cívico (SKINNER, 2000, p. 124-5). Skinner, sem descartar por completo a importância de causas externas, concentra-se nas causas internas, mas não aquelas que Najemy irá buscar na história social, mas no âmbito do discurso, o que está de acordo com seu contextualismo linguístico.

${ }^{162}$ Deveríamos nos perguntar mais sobre o significado desse caráter "naturalmente social e político do homem", pois a questão não parece estar bem resolvida. Significaria isso que o homem tem uma tendência natural à harmonia social? Por que parece a alguns que ser "social" é incompatível com ser "conflituoso"? Não é possível existirem animais sociais e conflituosos ao mesmo tempo? Era Aristóteles que pensava assim ou são determinadas leituras de sua obra? Penso no trecho antes citado da Política: "também a cupidez humana é insaciável, e embora inicialmente um subsídio de dois óbolos fosse bastante, quando este se tornou um direito adquirido as pessoas passaram a querer cada vez mais, sem nunca chegarem a um limite (o desejo por sua própria natureza não tem limites, e a maioria dos homens vive para sua satisfação)" (ARISTÓTELES, POLÍTICA, 1267b, p. 53). Tanto Platão como Aristóteles tomavam a pleonexia como um dado da natureza humana, apesar de tentarem ou neutralizála (Platão) ou canalizá-la, mantendo-a em um nível compatível com o bem comum (Aristóteles). Poderíamos ainda refletir sobre a consideração de que o homem é um animal político justamente por ser conflituoso, e que se não fosse, não seria necessária a política. 
política, sem a qual, a própria liberdade individual não estaria garantida. As leis, para Skinner, teriam a função de forçar os cidadãos a serem livres, como na formulação de Rousseau, típica da visão positiva de liberdade que Skinner queria rejeitar.

Como notou Silva, na interpretação skinneriana de Maquiavel há uma "tensão interna" na concepção de lei, que "remete ora à noção de liberdade positiva ora à noção de liberdade negativa" (SILVA, 2010, p. 47). Essa tensão interna pode ser explicada pelo fato de que Skinner queria afastar-se "das inclinações comunitaristas que julgava presentes em autores como Pocock", sem, entretanto, querer "assumir a concepção liberal clássica de liberdade negativa". Silva salienta ainda que a partir do texto "Liberdade antes do liberalismo", de 1999, o conceito de liberdade de Skinner passa a "assumir uma conotação mais claramente jurídica, na medida em que é associado ao status de determinado indivíduo na relação com outros indivíduos, com grupos ou com a coletividade”, concepção que se inspira no direito romano, que classificava o indivíduo como livre quando "não estava sob a tutela, a dependência ou a vontade arbitrária de outrem". (SILVA, 2010, p. 47).

Em comparação com Baron e Pocock, a interpretação de Skinner abre espaço para pensarmos o trágico em Maquiavel - o que defenderemos no próximo capítulo -, na medida em que expõe tensões entre Maquiavel e o humanismo cívico ${ }^{163}$, ao enfatizar o seu distanciamento em relação à concepção ciceroniana de virtude ${ }^{164}$, e ao não inserir Maquiavel na tradição do 163 Nas Fundações, Skinner afirma que em dois pontos Maquiavel adotou uma postura "inteiramente heterodoxa"
(SKINNER, 2000, p. 201): o papel positivo do conflito social e sua crítica ao cristianismo. Escreve Skinner:
"Insistir, assim, na espantosa sentença (para usarmos a fórmula de Maquiavel) de que 'os tumultos merecem o maior
louvor' não resultava apenas em destoar da admiração então corrente pela constituição veneziana; implicava,
também, pôr em questão uma das conviç̧ões mais arraigadas de toda a história do pensamento político florentino. O
outro ponto no qual Maquiavel veio a contestar as piedades dominantes foi na análise das conexões que existiriam
entre a busca da virtù e as exigências da fé cristã (...) Nos Discursos, Maquiavel constantemente salpica sua
argumentação com numerosos conselhos que revelam irrestrito endosso a uma escala de valores anticristã"
(SKINNER, 2000, p. 202 e 204).
164 "Mais uma vez Maquiavel expressa essa ideia parodiando os valores do humanismo clássico. Cícero declarara em
A Obrigação Moral que 'existem alguns atos tão repulsivos ou tão perversos que um homem sábio não os cometeria
nem mesmo para salvar seu país'. Maquiavel replica que, 'quando se trata absolutamente da segurança de seu próprio
país', torna-se dever de cada cidadão reconhecer que 'não pode haver nenhuma consideração quanto ao que é justo
ou injusto, piedoso ou cruel, louvável ou infamante; ao contrário, deixando qualquer escrúpulo de lado, ele deverá
seguir às últimas consequências qualquer plano que salve a vida da pátria e mantenha sua liberdade"' (SKINNER, 
"espírito de devoção e sacrifício" que entende a dedicação dos cidadãos à pátria como pura abnegação e vincula o sucesso da república à capacidade dos cidadãos afastarem-se dos “interesses” do seu grupo social. Segundo Skinner, Maquiavel pensava em outra solução para o problema do equacionamento entre as distintas partes da cidade e o bem comum, que consistia em um equilíbrio tenso entre forças sociais opostas:

“A solução, argumenta Maquiavel, consiste em organizar as leis relativas à constituição de modo a produzir uma relação de equilíbrio tenso entre essas forças sociais opostas, na qual cada uma das partes permanece envolvida com os negócios do governo, e cada uma 'mantém a outra sob vigilância' para impedir tanto 'a arrogância do rico' quanto a 'licenciosidade do povo' (...) Embora inteiramente motivadas por seus interesses egoístas, as facções serão assim levadas, como que por uma mão invisível, a promover o interesse público em todos os seus atos legislativos: 'todas as leis feitas em favor da liberdade' irão resultar de sua discórdia"'. (SKINNER, 1981, p. 103)

Retornaremos a ideia de que Maquiavel pretendia produzir um "equilíbrio entre forças sociais opostas". No momento, apenas registramos que a linha aberta por Skinner, e seguida por Viroli e Pettit, permite uma aproximação com o trágico em Maquiavel. Concordamos com Skinner e Viroli que a oposição entre liberdade positiva e negativa é uma falsa oposição, mas eles diluem ambas na liberdade negativa, já que a positiva seria apenas instrumental, quer dizer, o continuum entre as duas liberdades, para eles, seria a liberdade negativa, ou melhor, a "ausência de dominação", para usar os termos de Pettit. Esta concepção dilui a diferença entre as concepções republicanas e liberais de liberdade. Em Pettit, encontrar essa distinção começa a exigir um esforço maior por parte do leitor. Enquanto o liberalismo define liberdade como ausência de interferência, a concepção "republicana" de Pettit a define como ausência de um tipo de interferência, a arbitrária:

"Pettit destaca que não é qualquer forma de interferência intencional que se revela incompatível com a liberdade republicana, mas exclusivamente aquelas formas de interferência que podem ser qualificadas como

1981, p. 86). 
arbitrárias. E interferência arbitrária, para o autor, é sinônimo de dominação” (SILVA, 2010, p. 48) ${ }^{165}$

Não se está questionando aqui o mérito dessa concepção de liberdade como nãodominação, mas apenas a dificuldade de inserir Maquiavel nessa visão. Retornaremos a este ponto na próxima parte, no momento deixamos apenas alguns questionamentos: se Maquiavel entende a liberdade como não-dominação como explicar a valorização da grandeza em Maquiavel? Como explicar sua preferência pelo modelo popular e expansionista romano, em detrimento dos modelos aristocráticos e contidos de Esparta e Veneza? Como reduzir sua concepção de liberdade à "não-dominação" se, para o florentino, o não querer ser dominado corresponde apenas ao humor do povo, e o querer comandar corresponde ao humor dos grandes? Maquiavel não estabelece uma identidade entre o humor do povo e a liberdade, ao contrário do que defendeu McCormick (MCCORMICK, 2001; MCCORMICK, 2001)

Para John P. McCormick, Maquiavel é, sobretudo, um crítico do republicanismo. O republicanismo seria fundamentalmente aristocrático e teria uma visão tradicional respeito do conflito social, visto sempre como negativo. Maquiavel seria mais democrático do que republicano ao enfatizar os benefícios do conflito social e ao exigir mecanismos mais efetivos de controle das elites por parte do povo (MCCORMICK, 2003, p. 633), entretanto, segundo McCormick, em virtude do modo como a democracia é conceitualizada hoje, Maquiavel seria mais bem definido como defensor de um modelo populista e participativo, em razão da sua definição do povo como "guardião da liberdade", em oposição à nobreza com seu desejo ilimitado de oprimir (MCCORMICK, 2003, p. 634; MCCORMICK, 2001, p. 303).

Para McCormick, os estudiosos da Cambridge School moderaram Maquiavel, reduzindo-

\footnotetext{
${ }^{165}$ Hirschman havia notado a ideia de liberdade como ausência de interferência arbitrária no Segundo Tratado sobre Governo de John Locke: 'Locke diz que 'Liberdade dos Homens sob o governo' significa 'não estar sujeito à Vontade inconstante, incerta, desconhecida, Arbitrária de outro homem'. A incerteza em geral e a inconstância do homem em particular tornam-se por conseguinte o arquiinimigo que precisa ser exorcizado" (HIRSCHMAN, 1977, p. 74). McCormick considerou difícil reconhecer o republicanismo em Pettit: "Philip Pettit (1999) has set forth the most ambitious effort to put republicanism in the service of contemporary democratic theory. But it is less than clear what his undeniably powerful recommendations really have to do with republicanism at all”. (MCCORMICK, 2003, p. 633)
} 
o não apenas ao republicanismo, mas a um tipo de republicanismo que pouco se diferencia do liberalismo. McCormick reconhece a importância do trabalho destes autores para afastar as leituras que reduziam Maquiavel ao maquiavelismo (MCCORMICK, 2003, p. 617), e também considera positivos seus esforços para buscar no republicanismo recursos para uma crítica da concepção minimalista e liberal de democracia, entretanto, considera esses esforços inúteis, pois seu republicanismo seria incapaz de oferecer um limite às "mãos livres" que desfrutam as elites econômicas e políticas na democracia liberal ${ }^{166}$.

Segundo McCormick, apesar de terem reconhecido que Maquiavel inovou com sua visão positiva sobre o conflito social (MCCORMICK, 2003, p. 627), os autores da Cambridge School subestimam a sua importância e ignoram a insistência de Maquiavel no controle das elites, bem como os instrumentos para o exercício desse poder popular, especialmente as assembleias populares deliberativas, o direito de acusação pública, a instituição de julgamentos políticos pelo povo e o estabelecimento de instituições representativas exclusivamente populares (fechadas à participação da nobreza) com direito de veto e agenda. Para McCormick, outra deficiência da liberdade como não-dominação é que ela se restringe a ser uma liberdade contra a dominação política, mas silencia sobre a dominação social e econômica dos grandes sobre o povo ${ }^{167}$.

McCormick tem razão em apontar uma certa moderação de Maquiavel por parte da Cambridge School, mas exagera na tese do povo como "guardião da liberdade". McCormick reconhece que, para Maquiavel, o povo é o guardião da liberdade pelo fato de não ter oportunidade para oprimir. Entretanto, Maquiavel, por vezes, parecia apresentar o povo como

\footnotetext{
166 "I am convinced that republicanism, unless reconstructed almost beyond the point of recognition, can only reinforce what is worst about contemporary liberal democracy: the free hand that socioeconomic and political elites enjoy at the expense of the general populace" (MCCORMICK, 2003, p. 617)

167 "In short, largely due to his underspecifying of class conflict in Machiavelli, Skinner's conception of neo-roman liberty is noticeably weak on social domination. It mostly focuses on political domination: specifically, the way that subject-regimes and specific populations are treated by, respec- tively, imperial and absolutist rulers. But most economic inequality and social injustice do not fall into these categories. In The Discourses, Machiavelli, for his part, was concerned with domination of the people by those of wealth and status, not just by tyrants ". (MCCORMICK, 2003, p. 629)
} 
essencialmente bom e a elite como má168. McCormick sugere que a ênfase de Maquiavel no povo como guardião da liberdade seria um "exagero retórico" motivado pelo desejo de remover qualquer posição a priori em favor da nobreza, como era frequente entre os aristocráticos humanistas cívicos ${ }^{169}$. O exagero retórico de Maquiavel serviria para justificar a "proeminência do populacho sobre a nobreza em seu modelo" (MCCORMICK, 2001, p. 302). Quer dizer, para McCormick, Maquiavel não pensava a questão do conflito social em termos de equilíbrio, mas de predomínio do povo sobre a nobreza. Por esse motivo, Skinner estaria errado por "igualar normativamente as pretensões do povo e da nobreza" e defender que Maquiavel pensava o conflito em termos de equilíbrio. Desse modo, Skinner aproximava-se demais do modelo de Políbio, que, segundo McCormick, Maquiavel queria radicalizar (MCCORMICK, 2003, p. 627).

\section{Escreve McCormick:}

"Skinner acknowledges the originality of Machiavelli's political thought with respect to social discord (Skinner 1981, 65-66; 1990, 130, 136). But he interprets this discord in terms of an 'equilibrium' where equally dangerous motivations, those of the nobility and those of the people, are balanced. He often moves from a recognition of the two different social types that Machiavelli identifies, popolo and grandi, to a discussion of only one type: selfish humans who, under the right political arrangements, might become virtuous citizens (Skinner $1983,10-13)(\ldots)$ "But regarding the use of the term and concept of equilibrium, Skinner is much closer to the Polybian view (Polybius 1979, 317-18) that Machiavelli attempts to radicalize”. (MCCORMICK, 2003, p. 6267) Grifos nossos.

McCormick critica Skinner por reduzir os diferentes tipos sociais a um só, o dos "homens egoístas", homens que, em um arranjo político correto, poderiam se tornar cidadãos virtuosos.

\footnotetext{
168 "Or do plebs become elites once they ascend to power, such that they develop an appetite to dominate, a will to power, that makes them part of the nobility? If this is so, then the distinction between classes would revert to an argument about the opportunity to rule, rather than a question of disposition to rule. His approach seems to assume that all elites are bad. By starting from there, Machiavelli justifies three things: the populace's unqualified preeminence over the nobility in his model; the rather nasty relationship between the two classes; and greater vigilance over the nobles than might otherwise be required" (MCCORMICK, 2001, p. 302) Grifos nossos.

${ }^{169}$ Se McCormick as vezes parece pender para uma idealização do povo, Newton Bignotto, por sua vez, não deixa espaço para uma posição ambígua a este respeito: "Não há no pensamento de Maquiavel, no entanto, nenhuma idealização do povo. O que é criticado violentamente é a tese aristocrática, a esperança dos 'ottimati' florentinos de fundar uma nova Veneza, excluindo inteiramente o povo" (BIGNOTTO, 1991, p. 109)
} 
Esse questionamento de McCormick pressupõe que exista alguma diferença de fundo entre os grandes e o povo que não pode ser reduzida aos efeitos "dos arranjos políticos", ficamos então com a impressão de que há uma ambiguidade na posição de McCormick a respeito das causas dos diferentes humores, pois ora parecem derivar do meio institucional e social, ora parece haver uma idealização do povo, pois McCormick não explicita qual seria a razão para que Maquiavel não igualasse "as motivações igualmente perigosas" dos dois humores, nem explica porque não poderiam ser reduzidos a um só, como teria feito Skinner. McCormick limita-se a dizer que se Maquiavel considerasse o povo em essência tão ambicioso quanto a nobreza, o resultado seria o tipo de conflito faccional intransigente e corruptor, que era evitado pelo republicanismo tradicional e contemporâneo (MCCORMICK, 2003, p. 627). Nesse ponto, contrariando suas afirmações polêmicas, McCormick aproxima Maquiavel do republicanismo, pois também ele queria evitar o conflito "faccional".

Portanto, segundo McCormick, o modelo de Maquiavel não é nem o do equilíbrio, nem o do conflito faccional. Tampouco aponta para a superação das classes ${ }^{170}$. Então que modelo é esse? Continua sendo um governo misto, pois não pretende superar as classes, mas com prevalência popular, já que prevê uma série de mecanismos institucionais extra-eleitorais de controle das elites pelo povo e institutos de participação direta. Se McCormick entende que Maquiavel valorizava o conflito social, mas rejeita o conflito faccional, reconhece que a posição de Maquiavel não representa uma defesa da hybris. Mas então por que não entender este modelo como um modelo de equilíbrio? Talvez porque não apenas Maquiavel operava exageros retóricos contra o aristocratismo dos humanistas cívicos, mas também McCormick tem seus exageros retóricos contra os neo-republicanos da Cambridge School. McCormick não queria usar o termo 170 "Although Machiavelli shares Marx's indignation over elite power and class subordination, he does not think that
elites as a group can be eliminated or classes in general overcome (Marx [1848] 1996). In this sense, Machiavelli
anticipates his fellow Italian theorists of the "iron law of oligarchy" (Michels [1911] 1990; Mosca [1896] 1980;
Pareto 1987). But unlike them, and the Schumpeterian democrats with whom they have so much in common,
Machiavelli does not provide elites the expansive space within which to carry out their domination of the rest of the
people by celebrating their supposedly inevitable and irresistible ascendance" (MCCORMICK, 2001, p. 303) 
“equilíbrio" porque ele está solidamente integrado na tradição republicana aristocrática.

McCormick precisava marcar posição. Entretanto, o modelo de república que McCormick enxerga em Maquiavel também defende um gênero de equilíbrio. Qual seria a diferença entre os dois gêneros de equilíbrio?

McCormick afirma que os autores da escola de Cambridge acentuam a neutralização do conflito em sua interpretação de Maquiavel ${ }^{171}$. O termo "neutralização" nos fornece a pista para compreendermos a posição de McCormick, pois ele escreveu um livro sobre Carl Schmitt (MCCORMICK, 1997), e, como se sabe, Schmitt foi um crítico da "despolitização e neutralização" promovidas pelo liberalismo. Para Schmitt, esse processo resultou de uma resposta às guerras religiosas do século $\mathrm{XVI}^{172}$ e da busca por uma esfera neutra que pudesse diminuir os conflitos, entretanto, a neutralização produz uma perda de sentido, que torna o Estado vazio, formal, frio, e a política é progressivamente substituída pela técnica ${ }^{173}$. Os homens

171 "Hence Skinner puts a fairly typical Cambridge spin - accentuating the neutralization of conflict - on what is actually a Machiavellian inclination in The Discourses toward active, insubordinate, and impudent anti-elitism" (MCCORMICK, 2003, p. 628).

${ }^{172}$ Essa também era a avaliação de Koselleck, que via a soberania estatal e a separação entre legalidade e moralidade como resposta à guerra civil religiosa. Para Koselleck, a "neutralização" não resolvia a crise, pois a cisão entre o foro interno e o foro externo, entre a moral e a política, entre a sociedade civil e o Estado se aprofunda. A sociedade civil-burguesa que cresceu sob a proteção do Estado absolutista volta-se contra ele, a unidade representada pelo rei já não era capaz de dar conta da nova complexidade. Era necessária uma forma de unidade mais vaga. Não encarnada. Uma unidade menos exposta às incertezas da vontade, pois o poder soberano que promoveu a separação entre legalidade e moralidade neutralizou as vontades dos cidadãos, mas não a vontade do próprio rei soberano. Os financistas que cresceram sob a proteção do Estado absolutista e passaram a financiar o Estado começam a se voltar contra ele: "O acesso ao orçamento secreto e inatingível do Estado lhes era vetado. Não tinham nenhuma influência sobre a administração financeira e, como se não bastasse, também não possuíam nenhuma segurança para os seus capitais: a decisão real levava-os frequentemente a perder o dinheiro que haviam ganho com a especulação e o trabalho" (KOSELLECK, 1999, p. 58). Financistas e homens de letras unem-se na luta contra o Estado. Os homens de letras, reunidos nas sociedades secretas, procuravam encontrar uma pátria em um domínio a-político e a-religioso e a encontraram na moral, produto da religião confinada ao espaço privado. Eles são também produto do absolutismo, pois o predomínio do moralismo e do utopismo é conseqüência do confinamento do cidadão na vida privada, condenado a desempenhar um papel apolítico (KOSELLECK, 1999, p. 159-160). Para Koselleck, "a utopia burguesa é o 'filho natural' da soberania absolutista" (Id.). Em comum com os financistas, os homens de letras, excluídos do poder político, voltavam-se contra o Estado e também contra as incertezas da "vontade". "No bellum omnium contra omnes da república das letras, a moral sempre inventava novas razões para prevenir a ação soberana, para a qual não há um motivo, no sentido próprio do termo. Ela vivia trocando constantemente sua argumentação, pois não tinha, por natureza, acesso ao poder. Finalmente, teve que decapitar o monarca". (KOSELLECK, 1999, p. 160). Grifos nossos.

173 "According to Schmitt, since the religious wars of the sixteenth century, the West has been seeking a neutral sphere in which agreement could be reached and conflict diminished. This project was sponsored by intellectual elites who sought neutrality in various conceptual principles, Zentralgebiete or 'central spheres'. Europe moved from the controversial sphere of theology in the sixteenth century to the apparently neutral one of metaphysics in the seventeenth and, successively, to humanitarian morality in the eighteenth, to economics in the nineteenth, and finally 
e a natureza tornam-se objetos manipuláveis pela técnica. Entretanto, a técnica não produz sentido e seria cega em relação a fins, pode ser utilizada a serviço de qualquer "seita" e não é capaz de transcender a essa pluralidade conflitiva em busca de um princípio "unificador" capaz de evitar a desagregação social e a guerra civil.

A substituição da política pela técnica significa eliminar a representação, a capacidade de conformar a diversidade humana a partir de um princípio unificador que transcende essa realidade. A representação faz a mediação entre a matéria diversa da vida humana e a ideia transcendente unificadora. Por esse motivo, Schmitt buscou seu modelo de representação na Igreja Católica, que teria conseguido manter em seu interior uma diversidade de ordens sem perder a sua unidade. Ao contrário da Igreja, as seitas tendem a eliminar a diversidade de seu interior e colocar-se em antagonismo com as outras seitas. Schmitt preocupava-se com a eliminação da atitude representativa, e relacionava essa eliminação com o fim da metafísica ${ }^{174}$. O eclipse da representação é visto como consequência da vitória do pensamento "técnicoeconômico", que rejeitava qualquer transcendência, sem a qual não poderia haver "unificação". Quer dizer, Schmitt estava na perspectiva daqueles que procuravam superar o niilismo e nesse movimento, como Nietzsche, teria recorrido ao mito ${ }^{175}$ - não é a toa que uma das principais referências de Schmitt fosse a teoria do mito de Georges Sorel ${ }^{176}$, também ele um leitor de Nietzsche -, entretanto, apesar da semelhança na crítica ao niilismo e à "neutralização",

to technology in the twentieth" (MCCORMICK, 1997, p. 44)

174 "Tal vez sea éste uno de los núcleos esenciales del pensamiento schmittiano: hacer explícito el entramado entre metafísica y política, o más precisamente, que el agotamiento de la metafísica conlleva consecuentemente la muerte de la política, la cual deberá pensarse en las antípodas de una 'mera técnica administrativa'". (ROSSI, 2002, p. 90).

175 "despite the critically rational moments of Schmitt's analysis, he ultimately succumbs to the Nietzschean reversion to myth in an attempt to fend off the encroachments of demonized technology" (MCCORMICK, 1997, p. 28)

${ }^{176}$ Segundo McCormick, essa influência cresceu depois que Schmitt perdeu a esperança na capacidade da Igreja sustentar os mitos e passou a pensar em uma forma mítica secular: "In Political Form, Schmitt bristles at the suggestion by one of his intellectual heroes, Georges Sorel, that Catholicism no longer has the capacity to sustain such myths as the Antichrist. By the time of the 'Neutralization' piece, Schmitt may have come to see Sorel as correct, for he has turned to more secularly mythic means to overcome the age of technology. Indeed, Sorel is a kind of model for the type of cleric who can lead Europe out of its exhaustion: 'Sorel did not remain an engineer, but rather became a cleric"'((MCCORMICK, 1997, p. 104) 
Nietzsche e Schmitt eram muito diferentes. Schmitt não estaria preparado para aceitar a antítese entre "vida" e "mecânica" (MCCORMICK, 1997, p. 51), e Nietzsche, nos seus últimos escritos, deixava clara a sua rejeição ao gênero de restauração do mito que se iniciava na Alemanha e iria encontrar a adesão de Carl Schmitt.

Segundo McCormick, Schmitt considerava Maquiavel um pensador que já estava no espírito do "pensamento técnico econômico", pois entendia a política como um técnico e seria agnóstico em relação às diferenças substantivas entre os diferentes regimes (MCCORMICK, 1997, 131). McCormick, assume a ligação entre liberalismo e neutralização, mas discorda da solução autoritária de $\operatorname{Schmitt}^{177}$ e pretende oferecer uma interpretação alternativa de Maquiavel, que ele começa a partir de um artigo escrito durante seus estudos sobre Schmitt (MCCORMICK, 1993).

Quando McCormick afirma que Skinner acentua a neutralização do conflito e sugere que a inclinação de Maquiavel seria em direção a "um ativo, insubordinado e impudente antielitismo", ele dá um passo em direção ao Maquiavel trágico, quase percebe o agonismo do florentino, mas tende a idealizar a plebe, e, concordamos com Silva, McCormick continua na perspectiva da liberdade como não-dominação ${ }^{178}$, que no fundo reduz a liberdade à sua face negativa. McCormick esquece que, para Maquiavel, nas "repúblicas há mais vida”, e a república não poderia se restringir à ideia de liberdade como não-dominação. Como procuraremos mostrar na próxima parte, Maquiavel pensa o conflito na perspectiva do equilíbrio, como defendia Skinner, mas esse equilíbrio nada tem de neutralizador ${ }^{179}$, pelo contrário, significa um equilíbrio 177 Porque Schmitt pensava na construção do mito sempre de cima para baixo, a partir do Estado, e queria dar
visibilidade ao "político", ao conflito, mas apenas como inimigo externo, sendo neutralizador ou "hobbesiano"
contra o conflito político interno.
178 "A terceira interpretação dos textos maquiavelianos aqui examinada prefere compreender o secretário florentino
mais no âmbito da tradição democrática moderna do que no âmbito do republicanismo clássico. Contudo, parece-
nos mais apropriado compreender a posição do próprio McCormick como uma espécie de radicalização da
idéia de liberdade como não-dominação, central na formulação do republicanismo de Pettit e Skinner". (SILVA,
2010 , p. 53). Grifos nossos.
${ }_{179}$ Consideramos exagerada a crítica de McCormick de que o modelo de equilíbrio que Skinner via em Maquiavel
seria "neutralizador", pois sempre que Skinner tocava no tema do ele aparecia como equilíbrio tenso. Além do
trecho já citado, escreveu Skinner em outra parte, ainda sobre os Discorsi: "Observa, então, que, enquanto a plebe 
que permite uma expansão das forças vitais - expansão que é positiva -, no máximo nível possível antes que a disputa se transforme em disputa funesta.

Diante desta disputa entre interpretações da obra de Maquiavel e dos seus pressupostos, concordamos com Silva, que procurou responder a questão sobre o que os historiadores e teóricos do neo-republicanismo estão fazendo ao interpretarem a herança de Maquiavel. Segundo Silva:

“Com o objetivo de responder a questão formulada no final da seção introdutória deste artigo, procuramos mostrar que os historiadores e teóricos do neo-republicanismo estão assumindo, por intermédio dos textos e da autoridade de Maquiavel, distintas posições normativas nas disputas correntes entre os diversos modelos de organização das instituições políticas nas sociedades democráticas de nossos dias. De um lado, em uníssono, os neorepublicanos posicionam-se como alternativa ao pensamento liberal dominante, que insiste na defesa da "liberdade negativa", um modo de definir a liberdade como a ausência de toda forma de interferência externa nas escolhas e nas ações dos agentes individuais. Contudo, de outro lado, parece-nos evidente que o consenso negativo que une os neorepublicanos contra o pensamento liberal dominante se revela frágil tão logo é transcendido o momento da crítica do modelo liberal e se inicia o momento da afirmação do modelo republicano (...) Nesse sentido, a obra de Maquiavel foi aqui compreendida mais como um campo de disputas ideológicas, com recursos que podem servir a interpretações rivais, do que como um repositório de fatos e evidências textuais e contextuais à espera do historiador desinteressado." (SILVA, 2010, p. 54)

Se essa avaliação estiver correta, como pensamos que está, talvez seja o caso de rever antigos preconceitos contra Leo Strauss, pois ele foi enviado ao ostracismo acadêmico (não nos EUA) depois de ser acusado, pelos pesquisadores da Cambridge School, de ser a-histórico, por não dar a devida atenção ao contexto, criando ficções como a "grande tradição" que projetam no passado, anacronicamente, suas próprias preferências normativas. Vimos, entretanto, que as preferências normativas dos neo-republicanos também afetam suas interpretações da obra de

teve condições de 'congregar-se e clamar contra o Senado' e os senadores dispuseram de meios para vituperar a plebe, o resultado consistiu num equilíbrio, ainda que tenso, a assegurar que nenhum partido pudesse oprimir o outro ou ignorar-lhe os interesses" (SKINNER, 2000, p. 201) 
Maquiavel, que eles também são prescritivos ${ }^{180}$ e suas pesquisas também tem consequências para a teoria política contemporânea, não são, portanto, peças de antiquário, como disseram pejorativamente alguns críticos.

Passados 35 anos da publicação do grande Machiavellian Moment talvez seja o caso de superar o exagero nas reservas mútuas entre "contextualistas" e straussianos, pois, apesar das diferenças, que não devem ser "neutralizadas", nem os autores da Cambridge School são puramente contextualistas e desinteressados em teoria política contemporânea, nem Leo Strauss era alheio ao contexto histórico ${ }^{181}$, embora seus objetivos não fossem os mesmos do historiador. Talvez seja hora de retirar Strauss do ostracismo e trazer de volta para a arena este grande adversário.

É curioso como Strauss, acusado de ser a-histórico, tenha enfatizado as diferenças entre o pensamento de Maquiavel e a "grande tradição". Strauss destacou a modernidade de Maquiavel e nos apresenta um Maquiavel subversivo e perigoso, a começar pela ênfase de Strauss no anticristianismo do florentino, na sua maneira de ver a política do ponto de vista da plebe ${ }^{182}$ e na sua escrita subversiva direcionada aos jovens e audazes ${ }^{183}$. Do outro lado, os pesquisadores da Cambridge School, nas vertentes de Pocock e de Skinner, desenvolveram o contextualismo

\footnotetext{
${ }^{180}$ Para McCormick, Pocock seria o autor menos prescritivo da Cambridge School (MCCORMICK, 2003, p. 619). Skinner seria mais prescritivo que Pocock (MCCORMICK, 2003, p. 626) e menos que Pettit, este seria o mais prescritivo dos três e o que procurou vincular de modo mais direto e ambicioso os estudos sobre o republicanismo com o debate contemporâneo em teoria política (MCCORMICK, 2003, p. 633).

181 "It is necessary to be cautious about claims that past scholarship was 'unhistorical' and that the subject matter must be now approached with the 'methods of the historian' (Pocock 1971, p. 9). It would be to miss the point of much of the earlier literature to see it as a series of historiographical mistakes, and exactly what constitutes historicity is far from uncontentious (...) Strauss, for example, repeatedly stressed the need to understand the thinkers of the past in the manner in which they understood themselves, but seldom were the issues confronted directly" (GUNNEL, 1982, p. 318)

182 "It may easily appear that Machiavelli was the first philosopher who questioned in the name of the multitude or of democracy the aristocratic prejudice or the aristocratic premise which informed classical philosophy (...) But this bias in favor of the multitude enabled or compelled him not to identify simply with the aristocratic or oligarchic republicanism of the classical tradition (...) At any rate one may say that when indicating the character of the ruling class in the Discourses, Machiavelli views the ruling class from the plebeian point of view" (STRAUSS, 1958, pp. 127-8)

183 "Machiavelli addresses his passionate and muted call to the young - to men whose prudence has not enfeebled their youthful vigor of mind, quickness, militancy, impetuosity and audacity. Reason and youth and modernity rise up against authority, old age, and antiquity" (STRAUSS, 1958, p. 127)
} 
linguístico em oposição ao método supostamente a-histórico e ideológico de Strauss. Mas, de modo inusitado, os resultados das interpretações contextualistas nos apresentam um Maquiavel muito mais palatável ao gosto do homem liberal contemporâneo, que vive em um contexto bastante diferente da Itália renascentista, e em vez das diferenças, enfatizaram as continuidades, seja de Aristóteles aos federalistas, ou dos romanos a Pettit.

Antes de avaliarmos a interpretação de Strauss sobre Maquiavel e a relação do florentino com o trágico nesta chave interpretativa é necessário desfazer algumas interpretações rápidas demais do pensamento de Strauss. De um lado, os críticos pós-skinnerianos de Strauss o tomam como um conservador ingênuo e anacrônico, entretanto, boa parte deles não o leu, ou o fez de forma rápida e já informada por uma posição a priori. De outro lado, os seguidores apressados de Strauss não sabiam distinguir o ensinamento esotérico e exotérico de seu mestre e acreditaram que a "grande tradição" era a "verdadeira", tornaram-se conservadores ingênuos, não entendiam que pudessem existir posições diferentes e respeitáveis sobre as mesmas questões, mas apenas uma posição correta e verdadeira, aquela descoberta por Strauss, esqueceram que, para Strauss, sua própria posição era uma das "alternativas permanentes" que emergem na cidade, desse modo, os straussianos parecem ter perdido a capacidade de aprender com grandes adversários, como o próprio Strauss havia feito.

Se observarmos o conjunto da obra straussiana, como fez Lampert (LAMPERT, 1997; LAMPERT, 2005), perceberemos que Leo Strauss foi um pensador bastante sofisticado e que sua defesa da "grande tradição" não é ingênua. Se isto for verdade, então a interpretação straussiana de Maquiavel precisa ser reavaliada. Leo Strauss, o defensor da "grande tradição" da filosofia clássica e da Bíblia, começou sua vida filosófica por meio de sua leitura de Nietzsche, como ele próprio confessou. Lampert cita o estudo de Strauss sobre Nietzsche, no qual Strauss apresenta como verdadeiras as "verdades mortais" descobertas por Nietzsche. Nas palavras de Strauss, "as 
doutrinas verdadeiras da soberania do devir, da fluidez de todos os conceitos, tipos e espécies, e a ausência de qualquer diferença cardinal entre o homem e os animais". Strauss acrescenta ainda que o caráter mortal da verdade aparece de modo simples na "doutrina verdadeira de que Deus está morto". ${ }^{184}$ Que Strauss foi um ateu fervoroso em sua juventude é fácil demonstrar ${ }^{185}$, mas teria ele permanecido ateu?

Segundo Lampert, depois da juventude Strauss não foi mais um "cruzado ateísta", seus escritos pararam de defender abertamente o ateísmo, mas, em suas cartas a amigos, Strauss nunca parou de demonstrar seu ateísmo. Para Lampert, Strauss foi um leitor atento de cartas de filósofos, de Platão a Nietzsche, e, conscientemente, deixou suas próprias cartas disponíveis para que pudéssemos compreender melhor a sua obra. Lampert cita uma carta de Strauss a Gerhard Kruger, para quem a religião cristã era a "verdadeira" religião revelada. Nesta correspondência, Strauss escreve para Kruger: "nossa diferença reside no fato de que eu simplesmente não posso crer e eu portanto tenho que procurar por uma possibilidade de viver sem crença" (Leo Strauss, citado em: LAMPERT, 2005, p. 589).

Entretanto, poderia se objetar que essa é a resposta de Leo Strauss a um homem de fé cristã e não a um homem de fé judaica e que a carta ainda é de 1932, portanto, não prova que Strauss foi, por toda vida, um descrente. Lampert cita então uma carta de Strauss de novembro de $1960^{186}$ ao teólogo judeu George Scholem, que Strauss considerava "o mais profundo pensador judeu de nosso tempo". Strauss escreveu para Scholem:

\footnotetext{
${ }^{184}$ Strauss, L. Note on the Plan of Nietzsche's Beyond Good and Evil. In: Leo Strauss, Studies in Platonic Political Philosophy. Chicago: University of Chicago Press, 1983, par. 13, p. 180.

${ }^{185}$ Lampert cita diversos textos e cartas de Leo Strauss em sua juventude defendendo explicitamente o ateísmo. Cita, por exemplo, um texto de Strauss de 1929, "Zur Ideologie des politischen Zionismus", no qual Strauss defende que o sionismo político só pode ter como base o ateísmo, e, para Strauss, "não é necessária propaganda do ateísmo, as condições nas quais vivemos tem em geral mais impacto do que qualquer palavra falada ou escrita", e "nós não demandamos o ateísmo, nos o reconhecemos como um fato e poderoso, nós somos judeus sem fé". Em: Leo Strauss, citado em: LAMPERT, 2005, p. 589. Tradução nossa.

${ }^{186}$ É de se notar que essa carta de 1960 é posterior ao texto de Strauss sobre Maquiavel, Thoughts on Machiavelli, que foi publicado em 1957. Portanto, era um Leo Strauss ateu que acusava Maquiavel de ser um ateu perigoso e professor do mal. Disso emerge a questão: será que o livro de Strauss sobre Maquiavel era destinado ao grande público, era um livro exotérico? E os ensinamentos sobre "verdades duras" deveriam ficar restritos aos "iniciados"?
} 
"Você é um homem afortunado porque encontrou harmonia da mente e do coração em um nível tão elevado, e você é um bem para todo judeu que vive hoje. Como consequência, você tem o direito e o dever de falar. Infelizmente, eu sou constitutivamente incapaz de te seguir, ou, se você preferir, eu também jurei uma bandeira e o juramento na bandeira foi (no belo latim arábico criado por alguns dos nossos ancestrais, que para Cicero poderia ter aparecido in ultimitate turpitudinis): moriatur anima mea mortem philosophorum (que possa minha alma morrer a morte dos filósofos)". (Leo Strauss, citado em: LAMPERT, 2005, p. 590) ${ }^{187}$. Tradução nossa.

Para Lampert, o ateísmo ou a descrença não é algo incidental na obra de Strauss. Em 1952, vinte e três anos depois dos escritos ateístas de juventude, Strauss escreveu que "o tema genuíno, simples e profundo de toda a história do mundo e humana, em relação à qual todo o resto está subordinado, permanece o conflito entre a crença e a descrença” (STRAUSS, 1952, p. 107), e, segundo Lampert, Strauss ainda estava, como sempre esteve, do lado da descrença. Lampert cita uma distinção entre ateísmo antigo e moderno, na qual Strauss aponta que Nietzsche, como um ateísta moderno tardio, rejeitava as ideias religiosas porque elas eram "reconfortantes" e que essa rejeição pedia uma nova forma de fortaleza baseada na probidade intelectual. Descrevendo assim o que seria próprio do ateísmo moderno, Strauss fornece sua razão para romper com Nietzsche: "esse ateísmo com uma boa consciência, ou com uma má consciência, difere precisamente por seu caráter 'consciente', por sua moralidade, daquele ateísmo sem consciência com o qual o passado estremeceu" (Leo Strauss, citado em: LAMPERT, 2005, p. 592). ${ }^{188}$

Para Strauss, o ateísmo moderno rejeitava a ideia de Deus por razões de consciência, por isso, este ateísmo seria um “descendente da tradição fundada na Bíblia”, o ateísmo, nesta forma, seria o herdeiro e juiz da crença na revelação, da luta secular, milenar, entre a crença e a

\footnotetext{
$\overline{187}$ Strauss, L. Gesammelte Schriften 3:742. Lampert comenta ainda que Strauss repetiu essa frase em latim para Scholem em 1973: "Twice in the last months of his life, the second time a month before he died, Strauss repeated the Latin phrase in letters to Scholem, 7 July 1973, 30 September 1973 (ibid. 3:769, 771).

${ }^{188} \mathrm{O}$ que Strauss quis dizer com "O ateísmo sem consciência com o qual o passado estremeceu"? Referia-se aos sofistas? Referia-se ao materialismo de Demócrito e Epicuro? Ou à simples ausência, na religião pagã, de um Deus único, criador de tudo, com um plano e interessado em proteger o homem? Se for o último caso teríamos que incluir toda a cultura pagã greco-romana.
} 
descrença" (Leo Strauss, citado em: LAMPERT, 2005, p. 592). Portanto, para Strauss, essa forma de ateísmo seria menos radical, por ser "mais moral do que filosófica". Segundo Lampert, - de modo surpreendente para os críticos a priori de Strauss e para seus seguidores ingênuos Strauss rompe com Nietzsche porque ele seria meramente moral e herdeiro da Bíblia. Em 1962, - vinte e sete anos depois do texto do livro Philosophy and Law acima citado por Lampert, Leo Strauss, no texto Spinoza Critique of Religion, traduziu para a língua inglesa trechos de seu texto anterior e afirmou novamente que Nietzsche era um moralista cujo ateísmo derivava do próprio teísmo que ele rejeitava. Em outros textos, Strauss não considera mais Nietzsche dessa forma e afirma que sua teoria "sutil e nobre" da vontade de poder não aparece como derivada da tradição da bíblia e teria sido mal compreendida depois da morte de Nietzsche. ${ }^{189}$

Como mencionado anteriormente, Strauss afirmara em carta a Scholem que jurara outra bandeira, que não era a dos teólogos, mas sim a bandeira da filosofia. A oposição entre teologia e filosofia remete à oposição entre Jerusalém e Atenas, ${ }^{190} \mathrm{em}$ relação a qual Leo Strauss estaria do lado de Atenas (STRAUSS, 1967). ${ }^{191}$ Em What is political philosophy, Strauss escreve que Sócrates baseava suas decisões últimas não “em um apelo a um imperativo categórico que demandava obediência passiva, sem nenhum 'se' nem 'mas'" e que a decisão de Sócrates de não fugir diante de sua condenação baseou-se "em uma deliberação, em uma consideração prudencial

\footnotetext{
189 "Nietzsche's criticism can be reduced to one proposition: modern man has been trying to preserve biblical morality while abandoning biblical faith. That is impossible. If the biblical faith goes, biblical morality must go too, and a radically different morality must be accepted. The word which Nietzsche used is 'the will to power'. Nietzsche meant it in a very subtle and noble manner, yet the crude and ignoble way in which it was later understood is not altogether independent of the radical change of orientation he suggested" (STRAUSS, 1981, p. 28)

${ }^{190}$ Uma análise interessante desse texto de Strauss encontramos em SMITH, 1991.

${ }^{191}$ Smith, Steven B. Leo Strauss: Between Athens and Jerusalem. In: The Review of Politics, Vol. 53, No. 1, Special Issue on the Thought of Leo Strauss (Winter, 1991), pp. 75-99. Ver também Lampert: " 'What is Political Philosophy?' was first presented as three lectures in Jerusalem in 1954-55; Strauss published it in 1959 as the lead essay of a book assigned the same title, thereby making the essay very prominent. Strauss must have regarded the original occasion with some awe: a Jew who had become a man of Athens and taken as his ultimate theme Athens and Jerusalem speaks in Jerusalem on perhaps the greatest discovery of Athens. His situation reversed that of the Apostle Paul who traveled to Athens, bringing "Jerusalem" or news of the true God to those who raised monuments to "the unknown God.". Lampert. L. Nietzsche's Challenge to Philosophy in the Thought of Leo Strauss. In: The Review of Metaphysics, Vol. 58, No. 3 (Mar., 2005), p. 605.
} 
sobre qual seria a coisa certa a fazer nas circunstâncias dadas". ${ }^{192}$ Strauss, enfatizando, repete no final do parágrafo que a escolha de Sócrates "não consistiu na simples subsunção desse caso a uma simples, universal e inalterável regra". ${ }^{193}$ Em oposição, a tradição de "Jerusalém", requeria obediência passiva - sem nenhum 'se' nem 'mas' - a regras universais e inalteráveis dadas de uma vez para sempre por Deus para serem obedecidas, não questionadas. Haveria, para Strauss, uma “incompatibilidade entre filosofia e judaísmo". ${ }^{194}$

Em outro texto de Strauss, a incompatibilidade não seria apenas entre filosofia e uma religião monoteísta revelada, como o judaísmo, mas uma incompatibilidade entre filosofia e religião em geral, pois a filosofia seria "essencialmente incompatível com os deuses da cidade". ${ }^{195}$ Isso porque o filósofo seria movido pela paixão pela verdade (e não outra, como a paixão pelo conforto), entretanto, a filosofia é a busca da verdade e não a posse definitiva dela, como seria nas religiões, em especial nas religiões monoteístas reveladas. Para Strauss, diferente do homem seguidor de uma religião, o filósofo é aquele que "sabe que nada sabe" e que nessa busca da verdade, por meio apenas da razão, quer substituir as "opiniões sobre todas as coisas pelo conhecimento sobre todas as coisas" (STRAUSS, 1957, p. 344).

Para o filósofo Strauss, a força da obediência à moral é diferente na tradição da filosofia e na tradição da Bíblia. Para a filosofia, o que completa a moralidade é o entendimento ou a contemplação, o que tenderia a enfraquecer a "majestade das demandas morais". Na tradição da Bíblia, por sua vez, o que completa a moralidade é a humildade, o sentimento de culpa,

\footnotetext{
192 "That old Athenian philosopher of the Apology of Socrates was condemned to death by the city of Athens. He was given an opportunity to escape from prison: he refused to avail himself of this opportunity. His refusal was not based on an appeal to a categorical imperative demanding passive obedience, without if's and but's. His refusal was based on a deliberation, on a prudential consideration of what was the right thing to do in the circumstances" (STRAUSS, 1957, p. 361).

193 "His choice was a political choice of the highest order. It did not consist in the simple subsumption of his case under a simple, universal, and unalterable rule" (STRAUSS, 1957, p. 362).

${ }^{194}$ Leo Strauss em seu estudo sobre Maimonides, citado por Lampert em: LAMPERT, 2005, p. 600.

${ }^{195}$ Frase de Leo Strauss em The Spirit of Sparta or the Taste of Xenophon, p. 532. Citado em: LAMPERT, 2005, p. 603.
} 
penitência e a fé no favor divino. ${ }^{196} \mathrm{~A}$ força da obediência à moral seria maior na tradição da Bíblia. Daí a importância política da comparação entre as duas tradições, entre razão e revelação, comparação que, como observou Smith, assume em Leo Strauss um caráter "predominantemente secular ou político". ${ }^{197}$ Strauss, o descrente, está preocupado com os efeitos políticos da descrença.

Strauss encontra diferentes origens sociais para a filosofia e para a religião revelada. Para Strauss, a filosofia pertenceria à cidade e a religião revelada teria uma origem entre pastores no campo. Strauss, lembra que de acordo com a Bíblia o primeiro fundador de uma cidade foi também o primeiro assassino, e os seus descendentes foram os inventores das artes. ${ }^{198}$ É notável o viés anti-urbano desta passagem bíblica. A cidade aparece como um antro de corrupção desde sua fundação por um assassino. O campo, e o campo dos pastores, aparece como sede da tradição e do temor à Deus.

Se a cidade é o meio no qual se desenvolve a filosofia e com a filosofia as demandas morais são enfraquecidas, pois não encontram suporte em promessas divinas, então a filosofia é não apenas uma atividade superior, mas, ao mesmo tempo, um risco para a cidade, pois a relativização que ela promove, quando praticada por pessoas não cultivadas, poderia levar à

\footnotetext{
196 "The Bible and Greek philosophy agree indeed as regards the importance of morality or justice and as to the insufficiency of morality, but they disagree as to what completes morality. According to the Greek philosophers, as already noted, it is understanding or contemplation. Now this necessarily tends to weaken the majesty of the moral demands, whereas humility, a sense of guilt, repentance, and faith in divine mercy, which complete morality according to the Bible, necessarily strengthen the majesty of the moral demands" (STRAUSS, 1981, p. 37).

197 "This conflict, then, between revelation and reason, the Bible and philosophy, took on from the beginning a predominantly secular or political character. Philosophy, as represented in the person of Socrates, finds its natural home in the city. Philosophy presupposes a context of urbanity, wealth, and leisure to sustain it. The life of simple piety and humble awe, as extolled by the Bible and its most authoritative interpreters, by contrast, is unequivocal in favor of the rustic or pastoral life. According to the Bible, the first murderer was also the founder of the first city and the arts necessary for civilized life. It is no accident that it was not Cain, the tiller of the soil, but Abel, the keeper of sheep, who found favor in the eyes of God" (SMITH, 1991, p. 79). Grifos nossos.

198 "That asocial perfection which is contemplation normally presupposes a political community, the city, which accordingly is considered by the philosophers as fundamentally good, and the same is true of the arts, without whose services, and even model, political life and philosophic life are not possible. According to the Bible, however, the first founder of a city was the first murderer, and his descendents were the first inventors of the arts. Not the city, not civilization, but the desert, is the place in which the biblical God reveals himself. Not the farmer Cain, but the shepherd Abel, finds favor in the eyes of the biblical God" (STRAUSS, 1981, p. 37-8). Grifos nossos.
} 
corrupção. Strauss sempre enfatizou que a ideia de que não há nenhum risco no conhecimento só surge no pensamento moderno, primeiro a partir do séc. XVII, mas com mais intensidade a partir do iluminismo. O pressuposto de que a verdade nunca oferece riscos, tipicamente iluminista, estaria ausente tanto da filosofia política clássica quanto da tradição da bíblia. Para um iluminista, os mitos são dispensáveis e a "verdade" deve ser ampla e rapidamente divulgada, e não ser buscada com prudência apenas pelos iniciados. ${ }^{199}$ Como se sabe, Leo Strauss é crítico desta posição iluminista e se alinha com a posição da filosofia política clássica, que, tal como vista por ele, encontra sua maior expressão em Platão. ${ }^{200}$

Leo Strauss, seguindo a posição platônica, considera a filosofia política, como um ramo da filosofia que procuraria substituir as opiniões sobre a natureza das coisas políticas pelo conhecimento delas. Não obstante, a filosofia política é dirigida à cidade e pretende atuar nela, por isso deve pensar nos cidadãos como sua audiência, e não apenas nos iniciados em filosofia. Os cidadãos constituem a política, e esta se realiza, portanto, na esfera das opiniões/preconceitos. Estas opiniões são constitutivas da sociedade, são “os elementos por meio dos quais a cidade respira" ${ }^{201}$. O filósofo político deve dar um passo atrás e "retornar para a caverna", quer dizer, como Zaratustra, o filósofo deve "descer a montanha e tornar-se novamente homem" a fim de

\footnotetext{
199 Mesmo que faça críticas a aspectos do iluminismo e procure recuperar o "trágico" para pensar a política, Castoriadis, neste ponto, é absolutamente iluminista quando afirma que o mito é dispensável porque "o que é possível para ele seria possível também para todos os outros". Escreve Castoriadis: "Não tenho necessidade de simulacros e minha modéstia faz-me pensar que, a esse respeito, aquilo que é possível para mim é possível também para todos os outros. Ora, sua questão tem como pano de fundo a ideia de que apenas um mito poderia fundamentar a adesão da sociedade e suas instituições.” (CASTORIADIS, 2002, p. 267). Grifos nossos.

${ }^{200}$ Para Lampert, Leo Strauss não pode ser compreendido sem entendermos sua leitura de Platão e de Nietzsche e a ambiguidade essencial da posição straussiana em relação a estes: "His reading of Plato, like his reading of Nietzsche, like all of his contributions to his great innovation in opening up philosophy's esotericism, seem to me to argue for the latter: it is as a Platonic political philosopher that Leo Strauss may be a Nietzschean. It may even be that this ambiguity is essential to Strauss's thought; without it his doctrine may lose its character of an experiment or a temptation" (LAMPERT, 2005, p. 619).

201 "Philosophy or science, the highest activity of man, is the attempt to replace opinion about 'all things' by knowledge of 'all things'; but opinion is the element of society; philosophy or science is therefore the attempt to dissolve the element in which society breathes, and thus it endangers society. Hence philosophy or science must remain the preserve of a small minority, and philosophers or scientists must respect the opinions on which society rests. To respect opinions is something entirely different from accepting them as true" (STRAUSS, 1954, p. 64).
} 
que sua "boa nova" seja ouvida. ${ }^{202}$

Portanto, a filosofia política exige uma estratégia retórica diferenciada, na qual coexistem dois níveis de discurso entrelaçados, o esotérico e o exotérico. Essa convivência de dois níveis discursivos nos textos de filosofia política se faz necessária não apenas pela necessidade retórica de quem quer atuar sobre a cidade, mas também para proteger a filosofia da repressão da cidade. O mundo dos preconceitos, o mundo social, tende a hostilizar o espírito livre próprio dos filósofos. Não se pode esquecer que a filosofia política nasce após a condenação de Sócrates à morte pela sua própria cidade, que o acusara de "não acreditar nos deuses e corromper a juventude”. Segundo Strauss, para Platão a aceitação pelos filósofos da perspectiva política, ou seja, o recuo ao mundo da "caverna", também teria o benefício de moderar a "loucura" (mania) que Platão atribui à filosofia ${ }^{203}$.

Portanto, a interpretação straussiana de qualquer obra de filosofia política requer o trabalho de distinguir os dois níveis discursivos, o esotérico e exotérico, e procurar desvendar a intenção do autor. O que sugerimos é que ao apresentar uma obra de filosofia política aos seus leitores, Strauss também mantém, em seu próprio texto, a distinção entre os dois níveis discursivos. Isto pode confundir os leitores que não conhecem o conjunto da obra de Strauss, quer dizer, pode confundir os "não iniciados", que tenderão a considerar o nível exotérico do discurso (destinado ao grande público) como sendo aquele que Strauss considera "verdadeiro". Por isso, os leitores desavisados não podiam entender a "intenção" de Strauss ao escrever um

202 "To doubt the sacredness of the ancestral means to appeal from the ancestral to the natural. It means to transcend all human traditions, nay, the whole dimension of the merely human. It means to learn to look down on the human as something inferior, or, to leave the cave. But by leaving the cave one loses sight of the city, of the whole political sphere. If the philosopher is to give political guidance, he must return to the cave; from the light of the sun to the world of shadows; his perception must be dimmed; his mind must undergo an obfuscation" (STRAUSS, 1957, p. $360)$.

203 "But this obfuscation, this acceptance of the political perspective, this adoption of the language of political man, this achievement of harmony between the excellence of man and the excellence of the citizen, or between wisdom and law-abidingness, is, it seems, the most noble exercise of the virtue of moderation: wine-drinking educates to moderation. For moderation is not a virtue of thought: Plato likens philosophy to madness, the very opposite of sobriety or moderation; thought must be not moderate, but fearless, not to say shameless. But moderation is a virtue controlling the philosopher's speech" (STRAUSS, 1957, p. 360). 
livro como "Thoughts on Machiavelli". Não conseguiam entender como Leo Strauss podia retomar a pobre opinião do senso comum sobre Maquiavel, que considerava Maquiavel um "professor do mal". Strauss lhes pareceu mais um moralista e conservador ingênuo que queria defender a tradição da bíblia e da "idealista" filosofia política contra os ataques do "realismo" moderno iniciado por Maquiavel.

Entretanto, se o quadro geral do pensamento de Leo Strauss acima descrito estiver correto, o que diferenciava os antigos dos modernos, para Leo Strauss, não seria o "realismo" dos modernos versus o idealismo dos antigos, que "imaginaram repúblicas nunca antes vistas". Para Strauss, os filósofos antigos também eram realistas, também conheciam as "verdades duras" da política, mas reservavam a divulgação destas verdades apenas para os iniciados, e construíam para o grande público um discurso exotérico com uma intenção "edificante”. Os filósofos políticos clássicos, operando na realidade das opiniões e preconceitos próprios da caverna, seriam "fundadores", a construir a identidade da cidade com mitos adequados. Os filósofos produziriam mitos úteis para a cidade e o bem comum, pois não acreditavam que todos pudessem ou quisessem ser filósofos, e portanto, não acreditavam que a cidade pudesse se manter coesa apenas com o recurso à razão e a persuasão.

Para Strauss, os modernos iluministas seriam ingênuos por possuírem uma visão otimista da natureza humana, por acreditarem que a razão não ofereceria nenhum risco para a coesão social, sendo possível dispensar a distinção entre ensinamento esotérico e exotérico e o recurso ao mito e à força. No mundo antigo, os sofistas teriam sofrido desta "ingenuidade". Segundo Strauss, os sofistas acreditavam que a persuasão seria suficiente para governar os "muitos", assim, longe de serem "maquiavélicos", eles estariam sendo ingênuos ao acreditarem na onipotência do discurso e ao reduzir a política à retórica. Enquanto Xenofonte, na tradição "realista" da filosofia política, possuiria a "plena arte política", pois não acreditaria que a 
persuasão e a razão fossem suficientes para manter a coesão da cidade e o bem comum e que seria necessária a existência de "leis com dentes"204, com capacidade de coerção e estas leis precisariam ser apoiadas por "opiniões ancestrais", por mitos, porque a cidade como um todo era caracterizada como possuindo uma resistência à razão. ${ }^{205}$

Diante desse quadro, assume um novo significado a avaliação de Strauss sobre Maquiavel, pois quando Strauss acusa o florentino de ser um "professor do mal", um ateu contrário à tradição bíblica, ele não o faz por acreditar nessa tradição, mas por pensar que as “verdades duras” não devem ser divulgadas. É como se Strauss estivesse dizendo que Maquiavel foi ingênuo, assim como o iluminismo e mesmo Nietzsche também o foram, por apagarem a distinção entre esotérico e exotérico. Nesse sentido, Platão é que teria sido realmente "maquiavélico". Como Carl Schmitt, o conservador Leo Strauss temia os efeitos desagregadores do niilismo resultante do espírito iluminista, também entendia o político como Schmitt e era um crítico da neutralização promovida pelo liberalismo, por entender que a neutralização ofuscava o político e deixava o estado vulnerável (MCCORMICK, 1994, p. 628).

A "tecnologia" (arranjos institucionais que movem ambição contra ambição, sistema de pesos e contrapesos, administração, vigilância etc) não seria suficiente para manter a ordem social (MCCORMICK, 1994, p. 629). Para Schmitt e Strauss, em Hobbes existiam dois modos

\footnotetext{
204 "Xenophon on the other hand, the pupil of Socrates, possessed the full political art. The very same thought - the insufficiency of persuasion for the guidance of 'the many' and the necessity of laws with teet in them constitutes the transition from Aristotle's Ethics to his Politics. It is within this context that he denounces the sophist's reduction of politics to rhetoric. So far from being 'Machiavellians', the sophists - believing in the onipotence of the speech - were blind to the sternnes of politics" (STRAUSS, 1964, p. 23). Strauss cita as seguintes passagens "realistas" de Aristóteles na Política: 1254b22 - 1255a3, 1255b4-15, 1285a19-22, 1327b27-29, 1330a2533. Também cita Cicero, Republic II 57.

205 "Law, in contradistinction to the arts, does not owe its efficacy to reason at all or only to a small degree. (...) The law, the most important instrument for the moral education of 'the many', must then be supported by ancestral opinions, by myths - for instance, by myths which speak of the gods as if they were human beings - or by a 'civil theology'. The gods as meant in these myths have no being in and by themselves but only 'by law'. Yet given the necessity of law one may say that the principle of the whole both wishes and does not wish to be called Zeus [Strauss cita a Metafísica de Aristóteles em 1074b1-14]. Because the city as a whole is characterized by a specific recalcitrance to reason, it requires for its well-being a rhetoric different from forensic and deliberative rhetoric as a servant to the political art". (STRAUSS, 1964, p. 22). Grifos nossos.
} 
de entender o Estado: o modo mecanicista e o orgânico ${ }^{206}$. O modo mecanicista era criticado por ser insuficiente. Para Strauss, o Estado precisaria claramente defender uma visão de bem, deveria promover um determinado cultivo da natureza, ao contrário da concepção liberal, que entendia a cultura como algo natural, espontâneo, sobre o qual o Estado não teria nenhum papel (MCCORMICK, 1994, p. 627). Para Strauss, o mito é necessário para a coesão social (MCCORMICK, 1994, p. 636) e não se deve permitir que o processo de neutralização avance na transformação do Leviatã de mito para máquina (MCCORMICK, 1994, p. 638).

Leo Strauss era mais pessimista a respeito da natureza humana do que Schmitt ${ }^{207}$, e ambos eram mais pessimistas que Maquiavel e Nietzsche, por esse motivo, Strauss criticara Maquiavel por dizer a todos as verdades duras, por esse motivo Strauss quer restaurar o político, fazendo com que o Estado defenda uma visão de bem, mas não cogita estender esta restauração do político ao plano interno, abrindo espaço para a disputa na arena política, e para a ampliação da participação da plebe, pois dada a natureza humana, Strauss parece acreditar que a disputa sempre tende a se transformar em disputa funesta. Nesse sentido, Leo Strauss sempre esteve sob a influência de Platão.

Em contraste com a saída platônica, havia um modo trágico de lidar com essas questões que não pretendia eliminar o político nem a disputa, e também não entendia o Estado de modo puramente mecânico. Maquiavel compartilhava esse ponto de vista trágico, como pretendemos

\footnotetext{
206 "Strauss is familiar with Schmitt's attempt to separate the substantive Hobbes from the mechanistic Hobbes (CCP, 97, 103). Strauss is in full accord with this project to the extent that the substantive Hobbes recognized what characterizes man's fundamental condition and the element with which to manage it-fear. But one must further distance this from the other Hobbes who undermines his own insight by setting in motion the forces that will neutralize his system. Schmitt, in his failure to emphasize the radical dangerousness of man rather than what amounts to mere 'liberal' dangerousness, is susceptible to the subjectivity and the tendency toward neutrality and technology that characterize the latter Hobbes" (MCCORMICK, 1994, p. 631)

207 "The first view of cultivating human nature put forth by Strauss would, in line with the empirical reality of the state of nature, deem humanity as 'morally depraved' and simply and unequivocally in 'need of being ruled' (CCP, 97). It would hence rule out any 'autonomy' or 'subjectivity' for individuals, society, or culture, which instead must be kept under the tight control of the state. Strauss faults Schmitt, following Hobbes, for not being truly and exclusively pessimistic, for not identifying this more extreme dangerousness of humanity, and for not advocating singularly and explicitly a more direct mode to govern it”. (MCCORMICK, 1994, p. 629)
} 
mostrar no próximo capítulo. Entretanto, para Strauss, Maquiavel não era um autor trágico porque não há em seu pensamento um senso do caráter sagrado do comum e porque em Maquiavel o homem é o mestre de seu destino, pois ele pode subjugar a Fortuna ${ }^{208}$.

Questionaremos esta tese na próxima parte, no momento, não podemos nos esquecer que Strauss, um crítico da modernidade, exagera retoricamente a modernidade de Maquiavel a ponto de considerá-lo um precursor do iluminismo ${ }^{209}$, nem devemos esquecer que ele é um combatente conservador não ingênuo ${ }^{210}$, que conhece bem as outras posições, mas as apresenta ou esconde de acordo com as necessidades de seu discurso exotérico, de modo que precisamos saber ler Leo Strauss "nas entrelinhas", como ele sugeria que lêssemos os filósofos. Nesse sentido, se por um lado Strauss nega que Maquiavel seja trágico, por outro lado, afirma que Maquiavel opunha-se à tradição socrática - o que pode aproximá-lo da tradição trágica - e que, entre os antigos, Xenofonte, com sua Educação de Ciro, teria sido a principal referência para Maquiavel, e, segundo Strauss, Xenofonte é muito mais tolerante com o "desejo natural e ordinário de conquistar" ${ }^{\prime 211}$.

De qualquer modo, Strauss é um grande adversário, um leitor agudo que expõe bem os problemas e limpa a arena para um combate franco, de modo que somos convencidos de que Maquiavel estava em antagonismo com a filosofia política tradicional e com a tradição bíblica, que escrevia do ponto de vista da plebe e que sua escrita era subversiva. Aqui não há nenhuma

\footnotetext{
208 "There is no tragedy in Machiavelli because he has no sense of the sacredness of 'the common'. The fate of neither Cesare Borgia nos Manlius Capitolinus is tragic or understood by Machiavelli as tragic; they failed because they had chance or the times against them. As regards chance in general, it can be conquered; man is the master" (STRAUSS, 1958, 292)

209 "Machiavelli breaks with the Great Tradition and initiates the Enlightenment. We shall have to consider whether that Enlightenment deserves its name or whether its true name is Obfuscation" (STRAUSS, 1958, p. 173)

${ }^{210}$ Strauss identifica os clássicos que ele defende com os conservadores contemporâneos: "The classics were for almost all practical purposes what now are called conservatives" (STRAUSS, 1958, p. 298)

211 "The teaching which derives from this principle is obviously opposed to that of classical political philosophy or the Socratic tradition (...) For him the representative par excellence of classical political philosophy is Xenophon, whose writings he mentions more frequently than those of Plato, Aristotle, and Cicero taken together or those of any writer with the exception of Livy. Xenophon's Education of Cyrus is for him the classic presentation of the imagined prince (...) Xenophon appears to be much more tolerant of that 'natural and ordinary desire to acquire' than any other classic" (STRAUSS, 1958, p. 290-1)
} 
tentativa de amansar Maquiavel e o antagonismo aparece em sua forma mais pura, pois as mesmas características que são criticadas por Strauss, constituem para nós as maiores qualidades do florentino. 


\title{
CAPÍTULO 4 - MAQUIAVEL E O PONTO DE VISTA TRÁGICO
}

\author{
“'Nicolau Maquiavel, historiador, cômico e trágico'”212 \\ "Politicamente, Maquiavel pode ser melhor descrito como um discípulo de Heráclito"213
}

Poucos investigaram de modo direto as relações entre Maquiavel e o trágico. Recentemente, Rinesi (RINESI, 2002), Aguila (AGUILA, 2001) e Von Vacano (VON VACANO, 2007) fizeram trabalhos nesse sentido ${ }^{214}$. Os dois primeiros são trabalhos de qualidade e interesse, mas pensamos que é necessário explorar mais as relações entre Maquiavel e o trágico e suas consequências para a teoria política. O trabalho de Von Vacano avança mais na investigação sobre o trágico em Maquiavel, por meio de sua aproximação com Nietzsche, mas focaliza suas atenções mais na teoria estética e não desenvolve a questão de saber como o "trágico" em Maquiavel afeta sua teoria política.

Rinesi considera Maquiavel um autor trágico e busca mostrar isso principalmente com o apoio de comentadores contemporâneos e cria três características que seriam típicas de uma posição trágica em relação à política: a tragédia dos valores, a tragédia da linguagem e a tragédia da ação. A primeira relacionada ao politeísmo de valores, a segunda com os limites da linguagem e do conhecimento e a última com as incertezas da ação. Em seguida, Rinesi já parte para uma análise de Hamlet e do pensamento de Hobbes, porque o foco de sua tese não está concentrado em Maquiavel, a quem ele dedica apenas o primeiro capítulo, com atenção especial para a "tragédia da ação" em Maquiavel. Sentimos falta de uma elucidação das relações entre

\footnotetext{
${ }^{212}$ Modo como Maquiavel de autodefiniu ao assinar sua carta a Francesco Guicciardini, escrita em 21 de outubro de 1525. Em: MAQUIAVEL, 1989, p. 987.

213 "Politically, Machiavelli can perhaps best be described as a disciple of Heraclitus. The foundation of his teaching concerning politics is his claim that "all the things of men are in motion and cannot remain fixed" (RAHE, 1995, p. 452).

${ }^{214}$ Maurizio Viroli também faz menção ao trágico em Maquiavel. Para Viroli, Rousseau, apesar de admirador de Maquiavel, "nunca chega a confrontar a dimensão trágica da política que existiria em Maquiavel", entretanto, não desenvolve o tema, pois seu livro era sobre Rousseau. (VIROLI, 1988, p. 418)
} 
Maquiavel e os trágicos antigos. Também nos faz falta uma investigação sobre existência ou não de uma cosmologia trágica em Maquiavel e de uma concepção trágica do conflito e da liberdade.

Aguila, por sua vez, não considerou Maquiavel um autor trágico. Em nossa opinião, Aguila está equivocado e seu erro provém de uma visão formalista do trágico, pois Aguila toma a definição de tragédia de Aristóteles como "o modelo" do que seria trágico. Nessa forma de colocar a questão, se Maquiavel não apresentar todas as características definidas por Aristóteles como típicas da tragédia, então ele não é trágico. Ora, isso nos parece formalista demais e reifica a noção de trágico, pois toma a definição de Aristóteles como a única possível. Aguila também esquece que o interesse de Aristóteles era discutir o gênero artístico da tragédia, e que esse interesse artístico formal, embora relacionado, não pode ser imediatamente transposto para uma análise do "trágico" como visão de mundo. Entretanto, é mais o trágico como visão de mundo que podemos tentar encontrar em Maquiavel, pois, em termos de produção literária, Maquiavel foi um autor de comédias, e não de tragédias. Se é para buscar um apoio antigo para pensar o trágico como "visão de mundo", Aguila deveria ter se concentrado antes em Platão, com sua crítica aos trágicos, do que em Aristóteles.

Aguila reconhece que na teoria da ação de Maquiavel a "escolha está estruturada em termos trágicos" (AGUILA, 2001, p. 20). A escolha sempre se dá em meio à necessidade, porém, juízos de necessidade seriam sempre a posteriori, trabalho para historiadores, enquanto que os agentes da ação, no momento da escolha, não possuem nenhuma garantia de que o curso de ação escolhido é o correto. Quer dizer os julgamentos de "necessidade" não oferecem nenhuma paz de espírito aos agentes da ação. E frequentemente há conflito entre bem e bem, que em Maquiavel aparece principalmente na forma do conflito entre bem comum e moralidade. ${ }^{215}$ Entretanto, para Aguila, Maquiavel não seria trágico por não demonstrar compaixão, em especial compaixão pelo

\footnotetext{
${ }^{215}$ Retornaremos adiante a este ponto, apresentando como ele era entendido por Leo Strauss, Berlin e Skinner: "... if the promotion of the common good is genuinely your goal, you must be prepared to abandon the ideal of justice". SKINNER, 1990, p. 136.
} 
lado derrotado do conflito. A compaixão e o temor, e a catarse dessas emoções, seriam características da tragédia, segundo a definição de Aristóteles. Isaiah Berlin, citado por Aguila, apesar de mostrar as ligações de Maquiavel com uma moralidade pagã, também não considerou Maquiavel um autor trágico porque ele não demonstraria angústia nas escolhas feitas em conflitos trágicos. Maquiavel não seria trágico por não exibir nenhuma dúvida moral e nenhuma compaixão, sendo irônico demais para demonstrar compaixão. Já para Croce e Viroli, diz Aguila, Maquiavel seria um pensador trágico precisamente porque a ironia de Maquiavel seria um meio de expressar desgosto moral diante das condições cruéis do mundo.

Está errado o motivo usado para incluir ou não Maquiavel entre os trágicos. Dúvida e compaixão não constituem o núcleo do trágico como visão de mundo, o que seria percebido se tivessem buscado a definição do trágico em Platão, focada no conteúdo do trágico e não no gênero artístico trágico. Em Platão, teriam encontrado a origem do trágico em Homero, considerado por ele "o primeiro entre os trágicos". Para Kaufmann, a definição de Aristóteles tem problemas. A palavra "simpatia" seria uma palavra melhor do que compaixão ou piedade/pena para se referir ao sentimento que a tragédia desperta na plateia. A tragédia despertaria "simpatia pelos heróis", mesmo derrotados, e nos faria sentir "comovidos e perturbados pela miséria humana” (KAUFMANN, 1992, p. 44). Mas teria Maquiavel expressado simpatia pelo lado derrotado dos conflitos?

Sim, e isto aparece, por exemplo, no tratamento de Maquiavel sobre a "revolta dos Ciompi" em sua História de Florença, texto negligenciado por Aguila. A revolta dos Ciompi (trabalhadores mais pobres da indústria de lã) de 1378 provocou o ódio da oligarquia e dos próprios humanistas cívicos, que, em grande medida, teriam desenvolvido suas posições teóricopolíticas em resposta a este episódio. Depois do episódio dos Ciompi, os aristocráticos humanistas cívicos queriam enterrar o republicanismo popular de guildas ${ }^{216}$. Maquiavel, por sua

\footnotetext{
${ }^{216}$ Para Najemy, o projeto político do humanismo cívico era essencialmente conservador e "atenderia aos interesses
} 
vez, reconstrói com detalhes a posição derrotada dos Ciompi e demonstra simpatia pelo líder do "partido popular", Michel de Lando, algo que nenhum humanista cívico de seu tempo havia feito. $^{217}$

Para Maquiavel, o partido do povo e da plebe tinha suas razões no tumulto, eles reclamavam que o governo fazia injusta distribuição das magistraturas favorecendo os mais ricos, das "Artes maiores", enquanto que "os das Menores e seus defensores perseguiam". (MAQUIAVEL, 1525a, p. 159). Os da "ínfima plebe" que "labutavam”, ficaram sem "Artes" (guildas/corporações de ofício), e, portanto, sem representação no governo das guildas, e, quando “estavam ou não satisfeitos com suas fadigas, ou de algum modo oprimidos pelo patrão, não tinham outro lugar aonde dirigir-se senão ao magistrado da Arte que os governava, e do qual não lhes parecia que tivesse sido dada a justiça que julgavam conveniente dar” (Id). Segundo Maquiavel, em meio a esta indignação, um dos plebeus, "um dos mais ousados e de maior experiência", incita os outros à revolta. O discurso deste plebeu anônimo se dá num contexto de temor, por parte dos revoltosos, da punição em virtude dos incêndios e roubos cometidos durante a revolta, e o objetivo da plebe deveria ser, segundo o orador anônimo, "não sermos nos próximos dias castigados" e "poder viver com mais liberdade e maior satisfação própria do que no passado". Dada a ocasião, a única maneira de atingir esses objetivos seria a plebe partir para a revolta armada. Diz o plebeu anônimo:

“Reconheço que esta escolha é audaz e perigosa, mas quando preme a necessidade, a audácia julga-se prudência, e dos grandes perigos os homens de ânimo jamais tem conta; porque sempre as empresas que com perigo começam, com prêmio se terminam, e jamais de um perigo se saiu sem perigo" (MAQUIAVEL, 1525a, p. 161)

O plebeu diz que chegou a hora de "nos tornarmos totalmente príncipes da cidade" e que

\footnotetext{
da oligarquia pós-Ciompi”. Ver: NAJEMY, 2000, pp. 75-103.

${ }^{217}$ Para Sestan, Maquiavel foi o primeiro a buscar as razões dos derrotados Ciompi: "quem havia falado disso antes de Maquiavel tinha visto na sublevação da multidão um fato de psicologia coletiva, uma explosão de maldade e de raiva rapinante até então represada. Maquiavel é quem primeiro vê também motivos econômicos e sociais". Sestan, E. Echi e Giudizi sul Tumulto dei Ciompi nella cronistica e nella storiografia, p. 133. Citado em: ARANOVITCH, 2007, p. 263.
} 
a oportunidade era única para isto e os plebeus não deveriam se preocupar por não terem "sangue nobre":

"Que não vos desconcerte aquela antiguidade do sangue de que nos cobram falta, porque todos os homens, tendo tido a mesma origem, são igualmente antigos e pela natureza foram criados de um só modo. Fiquemos todos nus, e nos vereis semelhantes; vistamo-nos com as roupas deles e eles com as nossas: nós sem dúvida nobres e eles não nobres pareceremos; porque só a pobreza e a riqueza nos desigualam" (MAQUIAVEL, 1525a, p. 160).

É impressionante, pelo aspecto igualitário, em oposição ao aristocratismo dos humanistas cívicos, o discurso que Maquiavel atribui a este plebeu anônimo ${ }^{218}$. Devemos nos perguntar o quanto esse discurso não expressa as concepções do próprio Maquiavel, já que o discurso do "anônimo" plebeu teria sido proferido 147 anos antes de Maquiavel escrever sua História de Florença. Mas não é apenas neste discurso do plebeu anônimo que Maquiavel demonstra as razões da plebe e simpatia por esse lado derrotado. A sua avaliação do líder do "partido popular”, Miguel da Lando, que tentara amenizar o extremismo do "partido plebeu", por não acreditar na possibilidade de uma tal vitória naquele contexto, é igualmente simpática. Miguel é descrito como "homem sagaz e prudente, e mais grato à natureza do que à fortuna" e que "merece ser citado entre os poucos que tenham beneficiado sua pátria” (MAQUIAVEL, 1525a, p. 165).

Outra ocasião em que Maquiavel simpatiza com um lado derrotado é a sua avaliação positiva da virtù de César Bórgia, em O Príncipe, apesar de ele ter sido derrotado. $\mathrm{O}$ trágico confronto entre a virtù e a fortuna aparece com toda sua intensidade na exposição do caso César Bórgia, não simplesmente porque ele foi derrotado - o trágico nem sempre está associado a um final infeliz, como procuramos mostrar antes -, mas porque a virtù é condição necessária, mas não suficiente, para o sucesso político, pois mesmo com toda a virtù não há nenhuma garantia de sucesso. César Bórgia, para Maquiavel, possuía a virtù necessária para um fundador, mas foi derrotado por circunstâncias imprevisíveis, pois seu pai, Rodrigo Bórgia (Papa Alexandre VI),

\footnotetext{
${ }^{218}$ Para Leo Strauss, Maquiavel vê a classe governante do ponto de vista da plebe e isto apareceria "na parte mais chocante" ou na "mais maquiavélica" passagem de História de Florença, que teria sido "o discurso do plebeu florentino no ano de 1378" (STRAUSS, 1958. p. 127-128).
} 
que o apoiava, ficou doente e morreu. Maquiavel afirma que César Bórgia poderia ter resistido a este golpe da fortuna, entretanto, também adoeceu, o que facilitou a sua queda. Diante disso, conclui Maquiavel:

"Se, então, considerarmos todos os progressos do duque, veremos que ele construiu grandes fundamentos para um poder futuro; sobre os quais não julgo supérfluo discorrer, porque não saberia quais preceitos melhores dar a um príncipe novo, senão o exemplo de suas ações; e se seus modos de proceder não lhe aproveitam, não foi por culpa sua, porque foi fruto de uma extraordinária e extrema malignidade da fortuna" (MAQUIAVEL, 1513, VII, p. $79)^{219}$

Maquiavel fez uma avaliação semelhante sobre Felipe da Macedônia, apresentado como sendo um homem de virtù, apesar de ter sido derrotado pelos romanos:

“Felipe da Macedônia, não o pai de Alexandre, mas aquele que foi vencido por Tito Quinto, não tinha um Estado muito forte em relação à grandeza dos romanos e dos gregos que o assaltaram: todavia, por ser homem de guerra e que sabia manter o povo consigo e assegurar o apoio dos grandes, manteve por anos a guerra contra aqueles, e, se ao final perdeu o domínio de algumas, lhe restou, contudo o reino" (MAQUIAVEL, 1513, XXIV, P. $233)^{220}$

Essas são algumas indicações de que Maquiavel não se importava apenas com o resultado ou a utilidade, mas também com a performance do agente, por meio da qual avaliamos a sua virtù, entretanto, a própria virtù não é onipotente, e o poder da fortuna nas coisas humanas permanece grande. É típico do ponto de vista trágico admirar a virtù do herói, recomendar o exemplo de suas ações, mas, ao mesmo tempo, reconhecer que a virtù do heróis apesar de necessária, nem sempre é suficiente diante do poder caprichoso da fortuna.

\footnotetext{
${ }^{219}$ Maquiavel repete o diagnóstico: "porque ele, tendo grande ânimo e intenção elevada, não poderia governar de outro modo, e somente se opuseram aos seus desígnios a brevidade da vida de Alexandre e a sua doença" (MAQUIAVEL 1513, VII, p. 93)

${ }^{220}$ Em sua análise a questão da glória em Maquiavel, Helton Adverse cita a avaliação de Maquiavel sobre César Bórgia e Filipe da Macedônia e comenta: "A glória também é reconhecida naqueles que não conseguiram grandes resultados, naqueles que por 'uma maldade da Fortuna' não conseguiram atingir seus objetivos, como Cesare Bórgia e o homônimo do pai de Alexandre, Filipe da Macedônia. (...) A resposta que nos parece satisfatória é que a glória e a grandeza de um ator político excedem os resultados de suas ações. Como diz G. Sfez, 'não são os resultados que permitem decidir a grandeza desse nome de homem de glória'. Não é a eficácia o critério para avaliar as ações de um político. Mas essa é a perspectiva do pensador político; o vulgo, Maquiavel não se cansa de repetir, julga pelos fins" (ADVERSE, 2009, p. 233 e 235).
} 
Ainda nesse sentido, que não julga apenas pelo resultado, é necessário observar a visão crítica que Maquiavel tinha em relação aqueles que sobem ao poder com virtù, mas que, em vez de só entrarem no mal "se necessário", preferem governar sempre com a violência, traição, má fé. Para Maquiavel, este era o caso do tirano siciliano Agátocles, que de "condição ínfima e abjeta e tornou-se rei de Siracusa", e, na sua subida ao poder, "associou tanta virtù de alma e corpo, que, ingressando na milícia, pelos seus diversos graus chegou a ser pretor de Siracusa. Ao ser investido em tal posto, decidiu tornar-se príncipe e manter com violência e sem obrigação a outrem aquilo que lhe tinha sido conseguido por um acordo" (MAQUIAVEL, 1513, VIIII, p. 95), em seguida, prossegue Maquiavel, Agátocles “ordenou aos seus soldados matarem todos os senadores e os mais ricos do povo; mortos estes, ocupou e manteve o principado daquela cidade sem nenhuma controvérsia civil” (MAQUIAVEL, 1513, VIIII, p. 96). Maquiavel comenta que Agátocles teve sucesso em se manter no poder, pacificar os conflitos civis e libertar Siracusa do assédio dos cartagineses. Entretanto, seu modo de governar lhe permitiu conquistar o poder, mas não a glória:

“Quem considerar, portanto, as ações e a vida deste homem, verá pouca ou nenhuma coisa que se possa atribuir à fortuna, porque, como se disse acima, não pelo favor de alguém, mas pelos postos da milícia, os quais conquistou com mil incômodos e perigos, alcançou o principado; o qual posteriormente conservou com muitas resoluções corajosas e perigosas. Não se pode também chamar de virtù matar os seus cidadãos, trair os amigos, agir de má fé, sem piedade, sem religião: meios estes que permitem conquistar poder, mas não glória" (MAQUIAVEL, 1513, VIIII, p. 97) Grifos nossos.

Por que Agátocles conquistou o poder e não a glória? Não é simplesmente por ter recorrido à violência e à fraude, pois, para Maquiavel, “ao príncipe novo é impossível fugir da fama de cruel, por serem os Estados novos repletos de perigos”, e César Bórgia, um modelo de fundador para ele, "era tido por cruel: não obstante aquela sua crueldade pacificou a Romanha, uniu-a, reconduzindo-a à paz e à confiança” (MAQUIAVEL, 1513, XVII, p. 163). Mas se César 
Bórgia usou meios imorais quando necessários, Agátocles, por sua vez, perdeu a medida.

A avaliação de Agátocles está no famoso capítulo de $O$ Príncipe em que Maquiavel pergunta se é melhor ser amado ou temido. Maquiavel responde que "se gostaria de ser um e outro; mas porque é difícil conciliá-los, é muito mais seguro ser temido que amado, quando se deve ser desprovido de um dos dois” (MAQUIAVEL, 1513, XVII, p. 165). Agátocles escolheu o caminho de ser só temido. É o caminho mais seguro, quando não se pode ser, ao mesmo tempo, amado e temido, entretanto, para se conquistar a glória, é preciso ser amado pelo povo e ter realizado grandes feitos para o bem comum ${ }^{221}$.

A mesma valorização trágica da performance aparece em sua preferência pelo modelo romano de república. Para Maquiavel, Veneza e Esparta são os melhores modelos para quem procura prolongar a existência da república no tempo ${ }^{222}$, mas, ainda assim, ele prefere o modelo romano, visto como mais dinâmico e mais capaz de alcançar a grandeza ${ }^{223}$. A performance da republica romana o agrada mais do que a "sereníssima república" de Veneza. Para Viroli, Maquiavel preferia o modelo romano por ser o modelo de uma república bem ordenada, onde cada parte da cidade tinha o seu lugar adequado e os cidadãos pobres teriam a mesma chance de

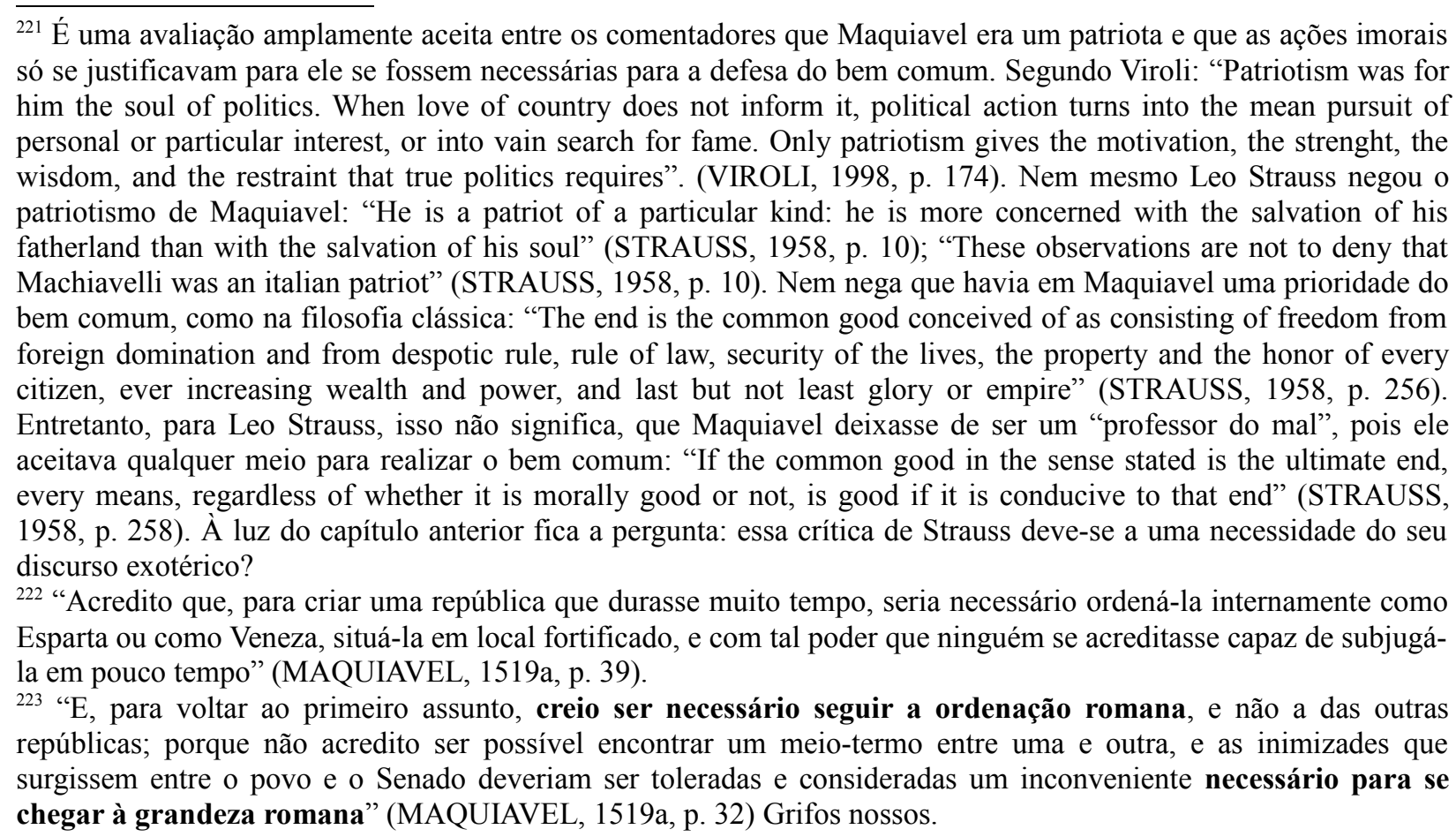


conseguir honras públicas ${ }^{224}$. Segundo McCormick, Viroli subestima a novidade de Maquiavel, que não consistia simplesmente em defender uma república "bem-ordenada", pois, no modelo de Maquiavel, haveria uma prevalência da plebe (MCCORMICK, 2003, p. 631) e este seria, segundo McCormick, o motivo para que Maquiavel preferisse o modelo romano: na república romana a plebe teria mais poder do que o senador romano Cícero gostaria que ela tivesse. Para Hulliung, Maquiavel preferia o modelo romano porque seria o mais adequado para a expansão territorial e o império, quer dizer, o modelo romano seria o melhor para alcançar a grandeza (HULLIUNG, 1983) 225 . A importância da grandeza na preferência pelo modelo romano também foi comentada por Leo Strauss (STRAUSS, 1958, p. 89). Para Pocock, em Maquiavel a "opção pela conquista às vezes era central e às vezes não" (POCOCK, 1985, p. 571), e criticou a tese de Hulliung por ser unilateral ao defender que o valor da cidadania para Maquiavel reduzia-se apenas à sua dimensão de conquista e que a república livre plebeia era preferida por ser mais capaz de dominar e destruir seus vizinhos (POCOCK, 1985, p. 570).

Para Hörnquist, tanto a posição de Hulliung quanto a dos autores associados à Cambridge School eram limitadas para compreender a preferência pelo modelo romano e o significado do termo grandeza em Maquiavel:

"Although Hulliung's interpretation has the merit of drawing our attention to the concrete, territorial, and action-centered aspects of greatness, it offers too crude and too restrictive a definition of Machiavelli's understanding of the term. If Skinner could be accused of overemphasizing the internal, or liberty-oriented, side of Machiavelli's republicanism by subsuming greatness under liberty, Hulliung can conversely be criticized for overstating its external and imperialist side by making liberty into a mere means for achieving greatness. The manifest limitations of these two conflicting interpretations oblige us to inquire more deeply into Machiavelli's

\footnotetext{
224 "Finally, and for Machiavelli this is a consideration of the greatest importance, in a good republic poor citizens have the same chance to attain public honours as anybody else: in Rome 'poverty did not bar you from any office or from any honour, and virtue was sought out no matter in whose house it dwelt"'. (VIROLI, 1998, p. 129

${ }^{225}$ Uma dos textos de apoio para Hulliung está nos Discorsi: "E no fim, quem examinar tudo sutilmente chegará a esta conclusão: ou se pensa numa república que queira fazer um império, como Roma, ou numa à qual baste manterse. No primeiro caso, é necessário fazer tudo como Roma; no segundo, pode-se imitar Veneza e Esparta, pelas razões e pelos modos que diremos no próximo capítulo" (MAQUIAVEL, 1519a, p. 25)
} 
general understanding of Roman history and the inner workings of the Roman republic" (HÖRNQUIST, 2004, p. 187-8).

Hulliung torna a liberdade civil instrumental para alcançar a grandeza. Skinner, e, podemos acrescentar, Viroli e Pocock, subordinam a grandeza à liberdade civil da república bem ordenada. Hörnquist nos fornece uma pista interessante para resolver o problema: a grandeza da república em Maquiavel deve ser entendida fundamentalmente como dependente da grandeza de ânimo do cidadãos (grandezza dello animo), tal como aparece nos Discorsi quando Maquiavel pergunta porque os antigos amavam mais a liberdade que os modernos cristãos e responde que a "nossa religião" tornou os homens menos fortes. O texto de Maquiavel é este:

"Pensando, portanto, nas razões de, naqueles tempos antigos, os povos serem mais amantes da liberdade do que nestes, concluo que isso se deve à mesma razão que torna os homens menos fortes agora, qual seja, a diversidade que há entre a nossa educação e a antiga, fundada na diversidade que há entre a nossa religião e a antiga (...) A religião antiga, além disso, só beatificava homens que se cobrissem de glória mundana, tais como os comandantes de exércitos e os príncipes de repúblicas. A nossa religião tem glorificado os homens mais humildes e contemplativos do que os ativos. Além disso, vê como sumo bem a humildade, a abjeção e o desprezo pelas coisas humanas, enquanto para a outra o bem estava na grandeza de ânimo, na força [fortezza] do corpo e em todas as outras coisas capazes de tornar fortes os homens. E, se nossa religião exige que tenhamos força [fortezza], é mais para suportar a força de certas ações do que para realizá-las” (MAQUIAVEL, 1519a, II, 2, pp. 189-190)

Para Maquiavel, defende Hörnquist, a grandeza da república romana dependia tanto das instituições republicanas, como ligava-se à expansão territorial ${ }^{226}$, mas, acima de tudo, a grandeza da república dependia da habilidade para produzir e promover nos cidadãos a “grandeza de ânimo” (HÖRNQUIST, 2004, p. 191). Entretanto, Hörnquist não investiga porque Maquiavel valorizava tanto a grandeza de ânimo e nenhum destes comentadores enfrentam

\footnotetext{
${ }^{226}$ Seria um erro não observarmos, em virtude de nossas preferências normativas atuais, que existia essa face expansionista no pensamento de Maquiavel e no republicanismo da época. Segundo Hörnquist: "The Renaissance idea that the Republic had two ends - one internal, centered around the classical concept of liberty (libertas), and one external, aspiring to acquisition of dominion (imperium), material goods, greatness, and glory - went back to the revival of Roman republicanism in the fourteenth century (HÖRNQUIST, 2004, p. 38). Além do próprio Hörnquist, as pesquisas de John Najemy, Alison Brown e James Hankins também têm ressaltado essa dimensão expansiva do republicanismo florentino (imperium). HANKINS, 1995; NAJEMY, 2000; BROWN, 2000.
} 
verdadeiramente a questão de saber porque Maquiavel prefere um modelo que ele próprio julga não ser tão duradouro quanto os modelos de Esparta e Veneza. A resposta a estas duas questões será possível depois de avaliarmos a cosmologia trágica de Maquiavel. No momento, queremos apontar ainda outros trechos em que Maquiavel não julga apenas pelo resultado.

Para Maquiavel, enquanto o modelo romano estimulava a grandeza de ânimo entre os cidadãos, as ordenações de Veneza, por sua vez, enfraqueciam os cidadãos e isto teria facilitado as derrotas de Veneza diante das tropas francesas em Vailate e a perda de parte de seus domínios para o papa e para o rei da Espanha. Os venezianos confiaram apenas na boa fortuna e sem estimular nos cidadãos a "grandeza de ânimo" ou a virtù foram derrotados de modo desonroso. Para Maquiavel, teria sido melhor vencer ou "perder com mais glória":

“Assim, se em Veneza e nas suas ordenações houvesse algum tipo de virtù, eles facilmente se recobrariam e mostrariam outra vez o rosto à fortuna, encontrando tempo para vencer ou perder com mais glória, ou então para fazer um acordo mais honroso. Mas sua covardia, causada pela má qualidade de suas ordenações, levou-os a perder de uma só vez o estado e a coragem. E isso sempre acontecerá a quem quer que se comporte como eles” (MAQUIAVEL, 1519a, III, 31, p. 416)

Maquiavel também demonstra considerar o lado derrotado do conflito na introdução do livro II dos Discorsi, quando critica os historiadores que idealizam o passado e se identificam com o lado dos vencedores, sem levar em conta o lado dos perdedores. ${ }^{227}$

Por fim, o próprio Maquiavel é um exemplo de cidadão que foi derrotado politicamente e sua vida e traços de sua personalidade, tal como expostos nas excelentes biografias de Roberto Ridolfi (RIDOLFI, 2003) e Maurizio Viroli (VIROLI, 1998a), nos revelam uma maneira trágica de encarar a vida - no sentido nietzscheano que liga trágico com alegria -, por meio de um estudo detalhado das cartas de Maquiavel e de amigos, testemunhos e análises de escritos menos

\footnotetext{
227 "Porque a maioria dos escritores se atêm de tal modo à fortuna dos vencedores que, para tornarem gloriosas as suas vitórias, não só aumentam aquilo que virtuosamente fizeram, como também magnificam as ações dos inimigos de tal modo que quem nascer depois em qualquer das duas províncias, na vitoriosa ou na vencida, terá razão para admirar-se daqueles homens e daqueles tempos, havendo de, forçosamente, louvá-los e amá-los" (MAQUIAVEL, 1519a, p. 177).
} 
conhecidos da obra do florentino.

Ridolfi menciona a carta que Maquiavel escreveu a seu amigo Guicciardini no final de outubro de 1525, em que ele assinou como "Maquiavel, historiador, comediógrafo e escritor trágico". Nesta carta, Maquiavel lamenta o fracasso do plano de expulsão dos espanhóis de Milão, ao qual havia dedicado toda sua energia, dizendo:

"Morone foi apanhado e o Ducado de Milão se danou, e como ele esperou para tirar o chapéu, o outros todos esperarão, não há mais remédio. Sic datum desuper [conforme menção acima]

Vejo da Alemanha retornar a flor-de-lis

E em seu Vicário...

Nosti versus, caetera per te ipsum lege [versos nossos, todos os outros valem para ti o mesmo]. Façamos desta vez um bom carnaval, e peçam a Barbera alojamento lá nos freis; que não se incomodem, eu não quero dinheiro; e cumprimentem Maliscotta, e avisem a todos a que ponto estão as coisas da comédia e quando pretendeis encená-la. Obtive aquele aumento de até cem ducados para a História de Florença. Agora começo outra vez a escrever e desabafo acusando os príncipes, que nos conduziram, todos eles, a esta situação" (Maquiavel, citado em RIDOLFI, 2003, p. 249).

\section{Ridolfi comenta esta carta:}

“A tragédia já estava no quinto ato, e era a tragédia da Itália. E sua vis tragica está inteiramente contida nessa prosa breve, com essas bruscas passagens do 'particular' ao universal juízo apocalíptico de uma política ruinosa, da lampejante profecia que milagrosamente antevê por meio de um verso de Dante [em ser vicário ter sido Cristo capturado] do despreocupado folguedo carnavalesco. Aqui está todo Maquiavel, e aqui ele é mais que nunca um símbolo de sua época e da Itália. Muito adequadamente se assinou no final desta carta, entre o sério e a brincadeira, logo abaixo das palavras: historiador, comediógrafo e escritor trágico" (RIDOLFI, 2003, p. 249).

Como notou Ridolfi, "sua vis tragica está inteiramente contida nessa prosa breve”, pois, diante de um grave revés, a reação do florentino não foi de tristeza e acusações contra a vida, mas de preparação para que "façamos desta vez um bom carnaval”, com a encenação de sua comédia Clizia. Era essa a sua atitude diante da vida, frente a dureza, as dificuldades e o fluxo do 
devir ${ }^{228}$, Maquiavel não se deixava abater ${ }^{229}$, nem condenava a vida ou buscava consolo fácil em "outro mundo", afirmava a vida inteira, com suas alegrias e sofrimentos, seja por um apolíneo desejo de imprimir forma e realizar grandes feitos, tal como na sua valorização da glória e da vida ativa, seja por um dionisíaco abandonar-se diante do inevitável e entregar-se às paixões e pequenas alegrias da vida.

A apolínea valorização da glória e do heroísmo perpassa toda a obra de Maquiavel e aparece também em suas cartas, e é amplamente reconhecida entre os mais diversos comentadores $^{230}$, já o seu lado “dionisíaco" é bem menos conhecido, mas aparece nas biografias que nos mostram que, em Maquiavel, o interesse pelas coisas grandes e graves, convive com a alegria das pequenas coisas, os amores e as tabernas. Viroli cita uma carta de Maquiavel a Vettori, de 31 de janeiro de 1515, que nos revela essa dupla face do florentino:

"Se alguém lesse nossas cartas, caro compadre, e visse a diversidade que há nelas, encheria-se de pasmo, porque teria a impressão de que ora somos homens graves, totalmente preocupados com as grandes coisas, incapazes

\footnotetext{
228 "O fluxo das desventuras humanas segue, para Nicolau, um ciclo inexorável. Não existe um progresso em direção à felicidade, ou à salvação, e sim uma eterna sucessão entre a ordem e a desordem, entre a virtude e o vício, entre o bem e o mal. Nada permanece o mesmo, nada se conserva imutável sob o sol: 'e é, e sempre foi, e assim será / que o mal suceda o bem, e o bem o mal', e um será sempre a causa do outro. Isso vale tanto para os Estados e os povos quanto para os indivíduos" (VIROLI, 1998a, p. 211).

229 "É preciso saber esperar e adaptar-se aos novos tempos, e quando os tempos são de amargura, de dor e de angústia, é preciso vivê-los com ânimo forte. Nicolau não quer chorar, 'porque o pranto ao homem sempre foi odioso, / deve-se, aos golpes da própria fortuna / voltar-lhe o rosto de lágrimas enxuto'. Sem lágrimas e quem sabe coberto por um sorriso que mascara, protege e alivia um pouco. Pode ser que a chave para compreender o significado de seu sorriso seja justamente essa concepção da vida que nos revelou em $O$ asno" (VIROLI, 1998a, p. 211). Viroli parece entender o trágico no seu sentido comum, de grave revés, infelicidade, e considera que o "sorriso de Maquiavel" era um modo de aliviar essa visão grave da vida e aliviar o fato de que a própria vida de Maquiavel era uma tragédia, desde caiu a república e ele foi destituído de seu cargo na chancelaria (VIROLI, 1998a, p. 249). Viroli não entendia o trágico em chave nietzscheana, trágico = alegria, mas os fatos e reações de Maquiavel descritos na sua biografia nos mostram essa visão no florentino. A exposição de Ridolfi, que comenta sobre a carta a Guicciardini que "aí está todo o Maquiavel" e que sua "vis trágica está inteiramente contida nessa prosa breve", aproxima, sem saber, ou sem explicitar, a atitude de Maquiavel diante da vida com a visão trágica tal como será entendida por Nietzsche.

230 "Unlike his friend Guicciardini, who believed that modern men do not long for glory, Machiavelli maintains that glory, along with riches, is one of the ends 'which everyone aims at'. The work to be done was then for him to rekindle the love of glory and direct it towards its proper goals (...) His belief in the possibility of reviving love of glory inspires most of his reflections on politics. He saw the love of glory as the only motive that might enable peoples to accomplish the grand deeds that liberty at times demands, like resisting tyranny and mobilizing against arrogant men who want to impose their domination. He also considered love of glory as the only motive that could drive leaders to accomplish the grand deeds that they alone can accomplish - that is, founding republics or kingdoms, liberating countries, redeeming a corrupt city" (VIROLI, 1998, pp. 39-40) Entre outros, ver também: (SKINNER, 2000, p. 140, 142, 199), (STRAUSS, 1958, pp. 281-291), (BALL, 1984).
} 
de abrigar em nosso peito um pensamento qualquer que não fosse em si grandioso e honesto. Porém, ao virar a página, imaginaria dessa vez que somos frívolos, inconstantes, lascivos e voltados às futilidades. Se essa conduta é condenável na opinião da maioria, é louvável na minha, pois assim imitamos a natureza, que é variada; e quem segue a natureza não merece ser repreendido" (Maquiavel, citado em: VIROLI, 1998a, p. 202)

Viroli comenta esta carta:

"Mesmo brincando, Maquiavel nos ensina a aceitar e respeitar a ideia segundo a qual cada um deve seguir a própria natureza, sem tornar-se escravo do julgamento dos outros”. (Id.)

Viroli cita como exemplo dessa tolerância de Maquiavel com aqueles que seguem sua “própria natureza”, sem se preocupar com o julgamento dos outros, o fato de que ele era amigo de Donato del Corno, notório homossexual de Florença e dono de um dos bares frequentados por Maquiavel. Quando não estava envolvido com as "grandes coisas", Maquiavel vivia uma vida libertina, entre tabernas, amizades com pessoas dos mais baixos estratos sociais, e com suas amantes, às quais ele se entregava completamente. Um dos exemplos que mais causaram constrangimento à Maquiavel ocorreu quando ele e uma amante sua tiveram que se defender na justiça da acusação de praticarem sodomia, um crime na época. Para Viroli, esse episódio, ainda que insignificante, confirmaria um importante aspecto da personalidade de Maquiavel:

“quando se tratava de paixões, desejos e prazeres, ele seguia apenas a natureza, isto é, sua natureza, sem se preocupar com as opiniões dos moralistas e das sentinelas da moral. Maquiavel era tão severo e respeitoso às leis na vida pública e política como era burlesco e libertino no campo do desejo e no amor”. (VIROLI, 1998a, p. 194)

Viroli menciona que certa vez Vettori pediu conselhos a seu amigo Maquiavel sobre a continuidade ou não de um caso amoroso que ele tinha com uma vizinha bem mais nova que ele, situação que se complicava por ser Vettori casado e "com filhas em idade de casar", e, Maquiavel escreve-lhe em uma carta:

"Não sei o que te dizer a não ser que deves seguir o amor totis habenis (sem freios), e o prazer que tiveste hoje, tu não o re-encontrarás amanhã. Se tudo aconteceu do modo como me contaste, invejo-te mais do que ao rei da Inglaterra. Suplico-te que siga a tua estrela [...], pois acredito, acreditei e sempre acreditarei que é verdade o que diz 
Bocaccio: 'é melhor fazer e arrepender-se, que não fazer e arrepender-se". (Maquiavel, citado em: VIROLI, 1998a, p. 199).

Ao que comenta Viroli:

"Essa era a sabedoria de Nicolau: diante da beleza da mulher, como das grandes coisas da política, não se deixava deter por temer o sofrimento ou a perda, mas deixava-se dominar pela paixão e seguia os grandes sonhos" (Id.)

Por meio das biografias, encontramos um Maquiavel trágico no dizer Sim à vida, "mesmo em seus problemas mais duros e estranhos", um homem que, como notou Nietzsche, conhecia a "arte do consolo daqui de baixo", sabia rir, e tinha a capacidade de expor os assuntos mais sérios num “indomável alegrissimo"231. Em suma, encontramos na biografia de Maquiavel, ao mesmo tempo, o impulso apolíneo no gosto pelas grandes coisas e a alegria na dissolução dionisíaca das identidades, das convenções sociais (apolíneas) que com falso moralismo bloqueavam o surgimento do novo e a "festa da reconciliação", dionisíaco presente em seu abandonar-se às paixões e à "natureza". Mas deixemos essa breve nota biográfica e retornemos aos textos do florentino.

Como entender a posição de Maquiavel, que, ao mesmo tempo, exibe um raciocínio estratégico, mas não julga as ações apenas pelo critério utilitário? Por que ele escreve tanto sobre a importância da virtù para o sucesso político, e, simultaneamente, afirma que a virtù não é suficiente diante da fortuna, dos "céus" ou do acaso cego? Por que Maquiavel valorizava mais o dinamismo conflitivo e a grandeza do modelo romano em vez dos mais duradouros modelos de Esparta e Veneza? A resposta a essas questões depende de sabermos mais sobre a visão de mundo de Maquiavel. Haveria uma “cosmologia trágica” em Maquiavel? Já é bem aceito que se há uma cosmologia em Maquiavel certamente não é a mesma da filosofia metafísica nem da tradição

\footnotetext{
${ }^{231}$ Além do já citado texto de Nietzsche, Leo Strauss também notou que no texto de Maquiavel convivem a gravidade e a leveza: "It is then of some importance to realize that the spirit of comedy, not to say levity, is not absent from his most serious books. In fact, gravity and levity are combined in these two books 'in a quasiimpossible combination' [Discourses and the Prince], just as they were in the man Machiavelli" (STRAUSS, 1958, p. 40)
} 
judaico-cristã. São bastante conhecidas as passagens em que Maquiavel se coloca em antagonismo com "os filósofos" e com o cristianismo. Mas quanto dessa oposição se deve a uma proximidade de Maquiavel com os trágicos?

Como vimos, para Platão, Homero era o "primeiro entre os trágicos" e as tragédias deveriam ser banidas da cidade, que deveria substituir os mitos "amorais" dos poetas pelos mitos criados pelos filósofos. Para Maquiavel, em certa medida, são os "filósofos" que constituem uma ameaça para a cidade, pois não enxergam a "verdade efetiva das coisas" e "imaginam repúblicas e principados que nunca foram vistos" (MAQUIAVEL, 1513, cap. XV, p. 153) 232, e a partir daí afirmam que, para os governantes, como para qualquer indivíduo, sempre seria racional seguir a virtude moral. Como é conhecido, para Maquiavel, se os governantes seguissem esse ensinamento não conseguiriam preservar o seu poder e a própria cidade iria à ruína. Maquiavel demonstra reserva com o "idealismo" dos filósofos e não parecia ter em alta estima a vida contemplativa, e, mesmo sendo um homem de letras, escreveu: "observam os sensatos que nas boas cidades as letras costumam vir depois das armas, e nas províncias como nas cidades os capitães vêm primeiro do que os filósofos” (MAQUIAVEL, 1525a, III, p. 229).

\footnotetext{
${ }^{232}$ Nesse trecho, é apenas implícita a crítica de Maquiavel aos filósofos "que imaginam repúblicas e principados que nunca foram vistos". O fato é que Maquiavel quase não cita os filósofos. Em $O$ Príncipe, Xenofonte é citado duas vezes; nos Discorsi, Xenofonte é citado oito vezes, Aristóteles uma vez e Platão uma vez; no Discursus Florentinarum Rerum, Aristóteles é citado uma vez e Platão uma vez; na História de Florença há apenas uma referência à "filosofia platônica", estimada, segundo Maquiavel, por Cosimo de Médici e Marsílio Ficino. Em nenhuma destas citações Maquiavel identifica sua posição com a dos filósofos nem expõe o pensamento dos filósofos. No Discursus Florentinarum Rerum, Maquiavel afirma que os filósofos Platão e Aristóteles fundaram repúblicas "por escrito" porque não as conseguiram fundar "em ato": "Io credo che il maggiore onore che possono avere gli uomini sia quello che volontariamente è loro dato dalla loro patria: credo che il maggiore bene che si faccia, e il più grato a Dio, sia quello che si fa alla sua patria. Oltra di questo, non è esaltato alcuno uomo tanto in alcuna sua azione, quanto sono quegli che hanno con leggi e con istituti reformato le republiche e i regni: questi sono, dopo quegli che sono stati Iddii, i primi laudati. E perché e' sono stati pochi che abbino avuto occasione di farlo, e pochissimi quelli che lo abbino saputo fare, sono piccolo numero quelli che lo abbino fatto; e è stata stimata tanto questa gloria dagli uomini che non hanno mai atteso ad altro che a gloria, che non avendo possuto fare una republica in atto, l'hanno fatta in iscritto: come Aristotile, Platone e molti altri; e quali hanno voluto mostrare al mondo che se, come Solone e Licurgo, non hanno potuto fondare un vivere civile, non è mancato dalla ignoranza loro, ma dalla impotenza di metterlo in atto" (MAQUIAVEL, 1521, p. 30). Nos Discorsi, há uma referência implícita aos filósofos Platão, Aristóteles e Políbio quando ele trata das formas de governo: "Outros - mais sábios, segundo a opinião de muitos - são de opinião que existem seis formas de governo, das quais três são péssimas e três são boas em si mesmas, mas tão fáceis de corromper, que também elas vêm a ser perniciosas" (MAQUIAVEL, 1519a, I, 2, p. 14). É curioso que Maquiavel tenha escrito "mais sábios, segundo a opinião de muitos", em vez de ele próprio considerar os filósofos sábios. Ele prefere manter a distância, escrevendo "segundo a opinião de muitos".
} 
Embora Maquiavel citasse poucas vezes os filósofos, e muitas vezes de modo pouco elogioso, com exceção para Xenofonte, ele conhecia suas obras. O pai de Maquiavel, Bernardo, preocupou-se em dar uma formação humanista para o seu filho. Segundo Ridolfi, em sua biblioteca, encontravam-se livros de Tito Lívio, Macróbio, Prisciano, Donato Acciauoli (sobre a Ética de Aristóteles), as Décadas, de Biondo, De Officiis, de Cícero, a Cosmografia, de Ptolomeu, além de livros de Plínio, Justino e a Bíblia (RIDOLFI, 2003, p. 20). Segundo Ridolfi, o jovem Maquiavel aprendeu latim e lia com fluência os poetas e historiadores latinos. Também teria lido, em traduções latinas, autores gregos, como Platão, Aristóteles, Xenofonte, Herodiano, Tucídides e Políbio. Segundo Viroli, depois destas primeiras leituras, Maquiavel teria lido, com particular dedicação, os poetas latinos:

“Os poetas latinos vinham em primeiro lugar, e acima de todos, Virgílio. Em seguida, aqueles poetas que ele chamava de 'menores' e que escreveram sobre o amor, como Tíbulo e Ovídio. Lucrécio ocupava um lugar à parte, com seu poema De rerum natura, que conta em versos a origem da natureza, dos mares, das plantas, dos animais e da condição humana. Nicolau não apenas leu como copiou o poema com esmero. (...) Leu depois os filósofos antigos, sobretudo os historiadores. Tucídides, que relatou a guerra entre Esparta e Atenas que iria dilacerar a Grécia; Tácito, que narra a corrupção e a perfídia de Tibério, Calígula e Nero, e, principalmente, aquele Tito Lívio, que o pai, Bernardo, havia adquirido (...) Entre os modernos amava Dante, Petrarca e Boccaccio” (VIROLI, 1998, p. 24).

Além destas leituras no seu período de formação, depois de deixar a chancelaria, com o retorno dos Médici ao poder, Maquiavel passa a frequentar os Orti Oricellari, “encontros realizados por um grupo de humanistas e literati que se reuniam regularmente nos jardins [Orti] de Cosimo Rucellai, nos arredores de Florença, para discutirem temas eruditos e também para entretenimento" (SKINNER, 1981, p. 79). Skinner comenta que essas discussões eram em geral de caráter literário e estimularam Maquiavel a canalizar suas energias criativas para a dramaturgia, e um dos resultados foi A Mandrágora. Mas também discutiam temas políticos e a maior parte dos membros do círculo dos Orti Oricellari eram contrários aos Médici e fervorosos 
republicanos, alguns deles chegaram a participar de uma conspiração fracassada para assassinar o cardeal Giulio de Medici em $1522^{233}$. Estas indicações mostram que Maquiavel, embora demonstre ter originalidade, estava profundamente inserido no universo dos humanistas cívicos, portanto, compartilhava o modo que os humanistas tinham de pensar os antigos em seus termos próprios, separados do contexto cristão, e a ideia de que seria preciso imitar os antigos. O modo como Maquiavel elabora esse programa o levou ao ponto de vista trágico.

Se as origens do trágico como visão de mundo estão em Homero e na religião pagã, os laços de Maquiavel com essas fontes nos ajudarão a entender sua relação com o trágico. Para Berlin, Maquiavel identificou dois ideais incompatíveis de vida e, portanto, duas moralidades e escolheu uma delas ${ }^{234}$. A escolha de Maquiavel teria sido pela moralidade pagã - cujos valores seriam a coragem, o vigor, a fortaleza na adversidade, a realização pública, a ordem, a disciplina, a felicidade, a força, a justiça e um poder que assegurasse uma vida política como "Péricles havia concretizado na sua Atenas ideal" e "Lívio encontrara na antiga República Romana" (BERLIN, 2002, p. 314). A outra moralidade, que Maquiavel abandona, seria a moralidade cristã, cujos ideais seriam "a caridade, a misericórdia, o sacrifício, o amor a Deus, o perdão aos inimigos, o desprezo pelos bens deste mundo, a fé na vida depois da morte, a crença na salvação da alma individual como algo de incomparável valor - mais elevado do que todo objetivo social, político ou qualquer outro propósito terrestre" (BERLIN, 2002, p. 314).

Berlin destaca também que, apesar da preferência de Maquiavel pela moralidade pagã, ele não considerou a moralidade cristã como má. "Ele não troca a ordem de nada”, diz Berlin, as virtudes cristãs são boas, também, entretanto, impediriam a existência do tipo de sociedade

\footnotetext{
${ }^{233}$ Skinner comenta a relação de Maquiavel com este republicanismo ardente: "Maquiavel nunca foi um partidário tão ardente da liberdade republicana a ponto de se sentir inclinado a associar seu nome com qualquer das várias conspirações contra os Médici. Mas é evidente que foi profundamente influenciado por seus contatos com Cosimo Rucellai e seus amigos" (SKINNER, 1981, p. 81)

${ }^{234}$ Quentin Skinner concorda com Berlin nesse ponto: “Assim, a diferença entre Maquiavel e seus contemporâneos não pode ser corretamente avaliada como a diferença entre uma visão moral da política e uma concepção da política que estaria divorciada da moralidade. O contraste essencial diz respeito, isso sim, a duas moralidades distintas duas exposições antagônicas e incompatíveis do que em última análise se deve fazer”. SKINNER, 1996, p. 155.
} 
preferida por Maquiavel. Por esse motivo, Berlin considera que Maquiavel teria rompido com o "monismo" que teria dominado o pensamento ocidental desde Platão e descobriu que existem "fins últimos" que são incompatíveis. Esse "relativismo" permitiu a Maquiavel, ao mesmo tempo, ter uma preferência e ser capaz de realizar uma análise fria das mais distintas formas de governo, o que, para Leo Strauss, significava uma imparcialidade imoral e inumana ${ }^{235}$.

Quer dizer, para Berlin, Maquiavel descobre o "politeísmo de valores" e o perspectivismo, características que nós atribuímos ao ponto de vista trágico. A não compreensão da moralidade preferida por Maquiavel, a pagã, ajuda a explicar a interpretação rápida demais daqueles que consideravam Maquiavel um “técnico da política”. Não é que Maquiavel seja um "cientista" indiferente às distintas formas de governo e moralidades, é que a sua moralidade pagã, "politeísta", trágica, não era "monista", para usar o termo de Berlin, não acreditava na existência de uma verdade moral universal válida para todos os tempos e encontrada por meio de algum critério objetivo. Desse modo, Maquiavel, apesar de ter sua preferência pela república com participação popular, não tinha como defender esse modelo para todas as situações e povos $^{236}$, nem possuía argumentos categóricos para negar a arbitrariedade fundamental de toda 235 "We called Machiavelli's detachment or neutrality inhuman, for, as he says, by nature men takes sides wherever there is a division which concerns them" (STRAUSS, 1958, p. 282). Para Strauss, apesar de ser republicano, Maquiavel é capaz de dar bons conselhos tanto para tiranos quanto para repúblicas e essa aparente neutralidade de Maquiavel no conflito entre tiranias e repúblicas seria normal, para Maquiavel, porque na opinião do florentino o maior bem comum é a "verdade": "the only good which is unqualifiedly the common good for all men is the truth, and in particular the truth about man and society" (STRAUSS, 1958, p. 283). Mas a "verdade" pode ser que a razão é apenas instrumental e incapaz de superar o politeísmo de valores. Um dos críticos dessa posição a acusará de "contradição performativa" (HABERMAS, 2002, p. 170).

${ }^{236}$ Por exemplo, a república não seria possível num povo "corrompido", sendo, nesse caso, preferível a monarquia, como escreve Maquiavel nos Discorsi: "Do que acabo de dizer, transparece a dificuldade, ou mesmo a impossibilidade, de manter-se o governo republicano numa cidade corrompida, ou de ali estabelecê-lo. De qualquer maneira, mais vale a monarquia do que o estado popular para assegurar que os indivíduos cuja insolência as leis não podem reprimir sejam subjugados por uma autoridade real” (MAQUIAVEL, 1519b, p. 77). Grifos nossos. Nas cidades com grande desigualdade social também seria impossível implantar a república, pois nelas os nobres consideram-se acima das leis, e os pobres são excessivamente humildes, nesse caso, só a monarquia poderia instaurar a ordem: "O reino de Nápoles, as terras da Igreja, a Romanha e a Lombardia ostentam essas duas espécies de homens; eis porque nunca houve nesses países governo regular, ou ordem pública: tal raça é inimiga declarada das instituições civis. Querer instituir governo num país assim organizado é tentar o impossível. Se se pudesse instaurar ali a ordem, isso seria apenas mediante a monarquia. A razão é a seguinte: onde há tantos motivos de corrupção, a lei não é mais do que um fraco obstáculo, sendo preciso apoiá-la com uma força mais difícil de resistir. Esta força reside no pulso forte de um rei; só seu poder absoluto e incontrastado pode por um freio à excessiva ambição e à corrupção dos poderosos" (MAQUIAVEL, 1519b, p. 173). Devemos ainda considerar que, para Maquiavel, há uma tendência natural à corrupção em todos os regimes, inclusive nas repúblicas, tendência que 
preferência última.

Essa concepção leva a pensar os conflitos morais em termos trágicos, como conflitos entre bem e bem. Pois, como disse Berlin, Maquiavel "não troca a ordem de nada", as virtudes cristãs são boas, também, mas são insuficientes não apenas para defender a república, mas para defender qualquer poder político, pois, para Maquiavel, uma liderança política com frequência depara-se com situações de escolha trágica, em que a liderança precisa agir de modo contrário às boas virtudes cristãs (bem) para salvar o bem comum (bem).

Para Leo Strauss, o que nós chamamos de conflito trágico entre bem e bem aparecia em Maquiavel como conflito entre virtude moral e virtude republicana ${ }^{237}$. A virtude moral é a virtude na sua concepção tradicional. A virtude republicana, por sua vez, seria aquela relacionada às qualidades necessárias para defender o "bem comum", segundo Strauss, entendido de modo "amoral", que seria a liberdade frente à dominação estrangeira e ao despotismo, o governo da lei, a segurança das vidas, da propriedade e da honra dos cidadãos, e o crescimento da riqueza e poder do país.

Para Maquiavel, prossegue Strauss, quando a existência da pátria está ameaçada ninguém deve se preocupar com "virtude moral", a justiça ou a injustiça, a compaixão ou a crueldade, o louvável ou o infame (STRAUSS, 1958, p. 259), pois sem o ambiente de segurança e liberdade criado pela República nem mesmo a virtude moral na vida privada dos cidadãos seria possível. É o Estado que cria o ambiente que torna possível a moralidade. Entretanto, a fundação do Estado não se dá por meios morais, e, na sua manutenção, frequentemente é necessário recorrer a meios imorais. Por isso, segundo Strauss, em Maquiavel “a moralidade só pode existir como uma ilha que é criada e protegida pela imoralidade" (STRAUSS, 1958, p. 255). Nesse sentido, a virtude

\footnotetext{
Maquiavel relaciona com os efeitos que a estabilização produz no caráter dos homens, para evitar a derrocada, a república deve ser capaz de se refundar periodicamente.

237 "One of the reasons why Machiavelli distinguishes between virtue and goodness is his desire to indicate the difference between republican virtue and moral virtue. Goodness in not always compatible with the common good, whereas virtue is always required for it" (STRAUSS, 1958, p. 257)
} 
republicana, para Maquiavel, estava acima da virtude moral. Esta também era a avaliação de Quentin Skinner, que comenta o mesmo trecho dos Discorsi citado por Leo Strauss ${ }^{238}$ :

“Maquiavel dá a resposta mais inequívoca possível. Não tem dúvidas de que a meta de manter a liberdade e a segurança de uma República representa o valor mais elevado, e mesmo decisivo, da vida política. Por isso, não hesita em concluir que não tem cabimento utilizar uma escala de valores cristã no exame dos assuntos políticos. Obviamente, aconselha a atuarmos da forma mais virtuosa a nosso alcance. Mas também recomenda, se a liberdade de nossa pátria exigir que trilhemos o caminho dos malfeitores, fazê-lo sem hesitar. Isso Maquiavel afirma com brutal clareza, quando, no final do último discurso, formula uma sentença que - diz ele - 'merece a atenção e deve ser seguida por todo cidadão que precise dar conselhos a seu país'. A sentença reza que, 'quando a segurança do país depender por completo da decisão a se tomar, não se deve levar em conta a justiça ou a injustiça, a bondade ou crueldade, ou a sua dignidade ou infâmia. Ao contrário, descartando-se qualquer outra consideração, deve-se optar, decididamente, por aquela alternativa que possa salvar a vida e conservar a liberdade do país'. A despeito das numerosas diferenças constatadas entre $O$ Príncipe e os Discursos, vê-se que a moralidade política subjacente aos dois livros é a mesma" (SKINNER, 1996, p. 203-4)

Aguila havia considerado que Maquiavel não seria trágico por não demonstrar simpatia pelo lado derrotado dos conflitos (o que, tentamos mostrar, não se sustenta) e por não exibir angústia diante deste conflito entre a moral e as medidas imorais necessárias para defender o bem comum. É verdade que Maquiavel não demonstra essa angústia, pois ele opta decididamente pela "virtude republicana". Entretanto, procuramos mostrar que a angústia não é uma característica suficiente para qualificar uma visão como trágica ou não, e que Aguila havia decidido incluir essa característica a partir da definição formal de tragédia feita por Aristóteles para o gênero trágico, e não para o trágico como visão de mundo. Para qualificar o trágico, neste ponto, basta a visão da colisão inevitável entre bem e bem e a compreensão de que a virtude moral deve ser sempre seguida, se possível ${ }^{239}$, mas que os líderes e cidadãos em uma república 238 "porque, quando se delibera sobre a salvação da pátria, não se deve fazer consideração alguma sobre o que é justo
ou injusto, piedoso ou cruel, louvável ou ignominioso; ao contrário, desprezando-se qualquer outra consideração,
deve-se adotar plenamente a medida que lhe salve a vida e mantenha a liberdade (MAQUIAVEL, 1519a, III, 41, p.
443 )
239 "Deve-se compreender que um príncipe, e em particular um príncipe novo, não pode praticar todas aquelas coisas
pelas quais os homens são considerados bons, uma vez que, frequentemente, é obrigado, para manter o Estado, a 
devem estar preparados para o trágico sacrifício deste bem em nome de outro bem maior.

Terence Ball também considera que Maquiavel fez uma opção por uma moralidade pagã, e procurou mostrar que a concepção de virtude em Maquiavel era uma concepção homérica ${ }^{240} \mathrm{e}$ que esta concepção não teria nada em comum com as virtudes cristãs ou ciceronianas. A palavra virtude não seria uma tradução perfeita para a areté homérica, pois esta se referiria a um conjunto de qualidades que permitiria a alguém preencher bem um papel e cumprir suas obrigações. A areté não seria nem mesmo uma qualidade específica do homem, falava-se na areté de uma espada, por exemplo, que seria sua afiação, de um cavalo, que seria sua velocidade, areté de um cão de guarda, expressa em sua ferocidade e lealdade ao mestre. O fiel cão de Odisseu exibia uma areté canina ao permanecer leal reconhecendo o seu mestre mesmo depois de longo tempo ausente. Penélope também teria exibido uma areté de esposa ao permanecer fiel ao seu marido, mesmo com todos os apelos dos pretendentes a se casar com esta suposta viúva. Para Ball, isso significa que ser virtuoso em um sentido homérico pode, em algumas ocasiões, requerer ações que seriam consideradas imorais para os nossos padrões. Areté seria a habilidade que alguém teria para executar as funções relacionadas com seus papéis. Aqueles que exibissem essa habilidade com sucesso acima da média adquiriam glória (kudos) ou fama (kléos). Para Ball, "não há nada como as regras de ouro, o imperativo categórico kantiano ou o princípio da universalização na ética homérica" (BALL, 1984, p. 527).

Para Ball, essa ética homérica aparece no príncipe virtuoso de Maquiavel, que mostra a sua virtù fazendo tudo aquilo que o seu papel e a necessidade (necessitá) de cada situação exige. Se a necessidade exige que ele aja de modo imoral, então ele deve agir assim, se ele não conseguir fazer isso ele terá falhado em seu papel, mostrando-se incapaz de executar sua

agir contra a fé, contra a caridade, contra a humanidade, contra a religião. Porém, é preciso que ele tenha um espírito disposto a voltar-se segundo os ventos da sorte e as variações dos fatos o determinem e, como acima se disse, não apartar-se do bem, podendo, mas saber entrar no mal, se necessário" (MAQUIAVEL, 1513, XVIII, p. 175

240 "My claim is that Machiavellian virtù shares some crucial affinities with the older Homeric conception of virtue" (BALL, 1984, p. 522). 
obrigação primária, que seria manter seu Estado e status. Ball considera que a metáfora usada por Maquiavel para a relação entre virtù e fortuna, segundo a qual a fortuna só se deixa dominar por aqueles que agem com audácia e não por aqueles que procedem friamente, revelaria sua noção homérica de virtude. Diz Ball, "a virtù é para a política o que a virilidade é para o sexo: o conjunto de qualidades que produzem sucesso nestas atividades nas quais o homem másculo, o vir viril, e o príncipe virtuoso estão respectivamente engajados. A virtù principesca é, com efeito, a interpretação atualizada e politizada que Maquiavel faz da areté arcaica" (BALL, 1984, p. 528). Segundo Ball, “o código moral de Maquiavel é, em uma palavra, heroico; ele se baseia em uma ética arcaica da emulação, não em uma reflexão racional sobre o certo, o justo e o bem" (BALL, 1984, p. 529).

Terence Ball tem razão em enfatizar a ligação de Maquiavel com uma ética pagã e homérica, que é visível na admiração do florentino pelo heroísmo e afeta sua concepção de virtù, mas ele exagera ao dizer que o código de Maquiavel é "em uma palavra, heroico", pois na ética puramente heroica não há tanto espaço para considerações estratégicas, que pressupõem que a razão pode contribuir para informar melhor os agentes em seus juízos prudenciais (não categóricos). Essa posição prudencial não significa nem o racionalismo moral iniciado pelo platonismo, nem a ética puramente heroica dos primeiros tempos, mas é uma posição perfeitamente inserida neste termo médio que é o ponto de vista trágico.

Ainda sobre a relação entre Maquiavel e a ética pagã, retornemos brevemente ao trecho já citado dos Discorsi em que o florentino compara a religião pagã com a cristã. Para Maquiavel, a "moderna religião" teria desestimulado o interesse pelas coisas "deste mundo" 241 e estimulado a fraqueza. ${ }^{242}$ Enquanto as religiões antigas "só atribuíam honras divinas aos mortais tocados pela

\footnotetext{
241 “Com efeito, nossa religião, mostrando a verdade e o caminho único para a salvação, diminuiu o valor das honras deste mundo. Os pagãos, pelo contrário, que perseguiam a glória (considerada o bem supremo), empenhavam-se com dedicação em tudo que lhes permitisse alcançá-la". (MAQUIAVEL, 1519b, p. 199).

242 "Quando se considera por que os povos da antiguidade amavam a liberdade mais do que os da nossa época, parece-me que a razão é a mesma que explica por que hoje os homens são menos robustos - o que se relaciona, a meu juízo, com a diferença entre a nossa educação e a dos antigos, e a diferença, igualmente grande entre a nossa
} 
glória mundana", a moderna religião "só santifica os humildes, os homens inclinados à contemplação, e não à vida ativa". ${ }^{243}$ Os pagãos, por sua vez, “davam a máxima importância à grandeza d'alma, ao vigor do corpo, a tudo, enfim, que contribuísse para tornar os homens robustos e corajosos. Se a nossa religião nos recomenda hoje que sejamos fortes, é para resistir aos males, e não para incitar-nos a grandes empreendimentos". É de se notar o "vitalismo" por trás desta valorização positiva dos "grandes empreendimentos", do vigor, da grandeza de ânimo, da coragem e da vida ativa.

Para Maquiavel, ao tornar os homens mais fracos, a moderna religião teria facilitado a vida dos tiranos, pois agora "estes sabem que podem exercer sem medo a tirania, vendo os homens prontos a sofrer sem vingança todos os ultrajes, na esperança de conquistar o paraíso" 244 . Apesar disso, Maquiavel não descarta a possibilidade de uma renovação do cristianismo que evite a interpretação "oficial” das escrituras que estimula a fraqueza. O ponto importante a reter é que permanece a associação antiga, que será característica do ponto de vista trágico, entre fraqueza e perda de liberdade, por um lado, e da liberdade com a fortaleza de caráter.

As críticas de Maquiavel aos filósofos e ao cristianismo foram possíveis em um momento como o Renascimento italiano, de certa crise da cristandade e de intensificação do contato com as obras da cultura antiga (pagã, heroica, trágica), o que facilitou o surgimento de visões cosmológicas alternativas à providência judaico-cristã. Para Cassirer, no Renascimento há uma volta ao naturalismo. Vínculos transcendentes são substituídos por imanentes. Vínculos religiosos e teleológicos substituídos por naturalistas. ${ }^{245}$ Koyré destacou a importância deste abalo na visão cosmológica medieval-cristã para o desenvolvimento da ciência moderna religião e a dos antigos" (MAQUIAVEL, 1519b, p. 199).

${ }^{243} \mathrm{Id}$.

${ }^{244} \mathrm{Id}$.

245 "as we move further into the Renaissance, we feel more and more that the advancement of the worldly spirit and of the worldly culture strengthens the tendency towards the basic doctrines of astrology. The basic magicalastrological view of causality comes to be interwoven in the whole Renaissance philosophy of nature (...) A transcendent bond is replaced by a naturalistic bond. And the latter was a harder one to surmount and surpass" (CASSIRER, 1963, p. 100). 
(KOYRÉ, 1991). Como é conhecido, a cosmologia medieval-cristã entendia o cosmos como criado, finito, hierárquico e teleológico. A escolástica medieval tratou de incorporar filósofos como Platão e Aristóteles, adaptando-os, tanto quanto possível, à sua visão cristã do cosmos. No Renascimento, para Koyré, houve uma revolução e “com Maquiavel, encontramo-nos verdadeiramente em todo um outro mundo. A Idade Média está morta. Mais ainda: é como se ela nunca tivesse existido. Nenhum de seus problemas - Deus, salvação, relações entre o mundos dos vivos e o além, justiça, fundamento divino do poder - existe para Maquiavel" (KOYRÉ, 1991, p. 17).

Para Koyré, Maquiavel teria antecipado a ciência moderna, mas esta só começa a ser desenvolvida de fato no século XVII. Quer dizer, a Renascença foi um período de transição entre duas cosmologias. A cosmologia medieval cristã e sua "síntese aristotélica" estavam abaladas, mas ainda não havia uma nova cosmologia para pôr no seu lugar. Assim, a Renascença se viu “sem física e sem ontologia, isto é, sem possibilidade de decidir, de antemão, se alguma coisa é possível ou não" e isso fez com que surgisse na época "uma credulidade sem limites" (KOYRÉ, 1991, p. 47), na magia, em oráculos e na astrologia, que não estava separada da astronomia e viveu uma efervescência, tendo estatuto de "ciência".

Parel abordou a relação de Maquiavel com a astrologia (PAREL, 1992), num estudo considerado por Pocock como "muito importante, interessante e uma contribuição original para os estudos maquiavelianos" (Id, na contracapa). Segundo Parel, a astrologia fazia parte do contexto intelectual de Maquiavel ${ }^{246}$. A ciência médica também tinha considerável repercussão neste meio. Essas foram duas das fontes do naturalismo renascentista ${ }^{247}$, para o qual também

\footnotetext{
${ }^{246}$ No campo da astrologia, Parel destaca o impacto da tradução para o latim, em 1136, da obra clássica de Ptolomeu sobre astrologia, o Tetrabiblos. Outro autor da astrologia que teve grande influência no contexto renascentista foi Abu Ma'shar que com sua obra De Magnis Conjunctionibus, disponível em latim. Nessa obra, o autor faz uma conjunção entre a a astrologia de Ptolomeu, a física e metafísica de Aristóteles e as teorias médicas de Hipócrates e Galeno, e desenvolve uma teoria dos efeitos causais sobre a história, a política e a religião. Para Parel, o impacto da teoria de Abu Ma'shar foi tremendo no pensamento astrológico da Renascença e pretendia "fazer nada menos que a redução da história a uma filosofia natural" (PAREL, 1992, p. 12).

${ }^{247}$ Outros comentadores notaram o "naturalismo" no pensamento de Maquiavel: Baron, Hans. Towards a More
} 
contribuiu o "naturalismo" pré-teleológico presente nas obras literárias da cultura antiga que estavam sendo resgatadas. Segundo Parel, a influência "naturalista" aparece na teoria política de Maquiavel, especialmente na relação que estabelece entre "os Céus" e a política, entre a virtù e a Fortuna e na sua teoria dos humores (umori). Para Parel, o uso dos termos umori e virtù estariam relacionados a este naturalismo. ${ }^{248}$ Parel mostra diversos trechos das obras de Maquiavel que indicariam que ele acreditava na influência dos "Céus" sobre o destino dos países e dos homens, e até mesmo indícios de que Maquiavel também acreditava ser possível conhecer essa influência dos Céus por meio de consulta a astrólogos e adivinhos. Segundo Parel, além de trechos das suas obras que sugerem isso, o próprio Maquiavel teria consultado astrólogos antes de tomar decisões quando membro da chancelaria florentina.

Para Leo Strauss, ao contrário de Parel, Maquiavel não teria fé no Deus cristão, nem nos deuses pagãos, nem na Fortuna e nem nos “Céus” de um modo místico. Para Strauss, Maquiavel seria um descrente que escondia a sua descrença ${ }^{249}$, e usava esses termos como metáforas para se referir a tudo aquilo que não estava sob controle do homem no momento da ação. Para os nossos propósitos, não importa tanto sabermos se Maquiavel acreditava na influência nos "Céus" e na Fortuna ou se utilizava esses termos de modo metafórico. O fato é que, em ambos os casos, Maquiavel se move no interior de um ponto de vista trágico, que pode perfeitamente ter uma versão religiosa ou não ${ }^{250}$, assim como os pressupostos da religião judaico-cristã permanecem existindo, de modo consciente ou não, em diversas filosofias laicas surgidas no interior da

Positive Evaluation of the Fifteenth-Century Renaissance. In: Journal of the History of Ideas, Vol. 4, No 1 (jan, 1943), p. 45; Chabod, Federico. Machiavelli and the Renaissance. New York, 1965, pp. 213-15. Garin, E. Italian Humanism. Oxford, 1965, p. 185; Sasso, G. Studi su Machiavelli. Napole, 1967, p. 281; Gilbert, F. Machiavelli and Guicciardini: Politics and History in Sixteenth-Century Florence. Princeton, 1965, p. 330. Leo Strauss também considerou que Maquiavel possuía uma cosmologia, e nela não havia espaço para uma mente que governa o universo, mas Strauss não decide se a cosmologia de Maquiavel seria "um tipo de aristotelismo" ou "demócritoepicúrea". Ver: STRAUSS, 1958, p. 222.

${ }^{248}$ Gilbert também notou que a virtù de Maquiavel tinha relação com a virtù da ciência médica da época, que sugeria "vitalidade". A virtù não teria na época apenas o significado derivado do vocabulário da moral. Ver: GILBERT, 1951, pp. 53-55.

${ }^{249}$ Esse também era o caso do próprio Leo Strauss, como procuramos mostrar no capítulo anterior.

${ }^{250}$ Mesmo entre os antigos era assim. Ésquilo era religioso e Eurípides era influenciado pela sofística e considerado por muitos como "ateu”, mas ambos eram poetas trágicos. 
cultura judaico-cristã. Para os nossos objetivos, o importante é que cada um desses pontos de vista sobre o cosmos e o homem tem características estruturais comuns e com determinadas consequências éticas e políticas.

O naturalismo reforça as afinidades de Maquiavel com o que chamamos de ponto de vista trágico $^{251}$. A astrologia, por caminhos diferentes, chega a uma visão do cosmos semelhante à visão trágica, pois na cosmologia trágica o cosmo é entendido como uma ordem precária construída sobre o Caos, permeada pela relação entre necessidade e acaso, sem um plano divino com alguma intenção moral a reger o cosmo e sem nenhuma garantia de compensação em outro mundo, o que significa que o homem não tem nenhum status especial nesta ordem trágica do cosmos. Para a astrologia, existiria uma ordem cósmica formada pelos movimentos dos planetas, cujas mudanças de posição determinariam a qualidade "dos tempos", afetando as mudanças e humores na terra, nos países e nos homens. Não há nenhuma intenção, vontade racional e moral, justiça ou injustiça, por trás desses movimentos do cosmos, que acontecem "naturalmente". Entretanto, para Ptolomeu, essas mudanças astrais seriam apenas uma causa geral que ainda permite que os indivíduos possam agir de acordo com seu temperamento ou de acordo com as "antipatias fortuitas" dos "Céus" (acaso/fortuna). Para Parel, isso que dizer que "em outras palavras, o universo é apenas imperfeitamente determinado, e os humanos podem, com o conhecimento 'científico' astrológico apropriado, escapar dos piores efeitos do determinismo universal" (PAREL, 1992, p. 12).

Segundo Parel, na época de Maquiavel esse naturalismo astrológico foi associado ao naturalismo da física e da medicina e adquiriu um viés implicitamente anti-cristão, contrário às doutrinas da providência, da imortalidade da alma, da origem sobrenatural da cristandade. As próprias religiões passaram a ser vistas, nesse meio "intelectual-científico", como produto dessa

\footnotetext{
${ }^{251}$ No primeiro capítulo mostramos que Nietzsche, um dos mais emblemáticos trágicos modernos, teria, segundo Moura, o "Projeto geral de elaborar uma filosofia que promova a naturalização integral da existência" e entendia o cristianismo como a matriz primeira da desnaturalização. Ver: MOURA, 2005, p. 185-6.
} 
ordem natural, e teriam valor por sua utilidade, mas não por sua verdade (PAREL, 1992, p. 14).

Contra esse viés naturalista se moveram os teólogos cristãos e os humanistas da época. Parel aponta o teólogo Savonarola e o humanista Pico de la Mirandola entre os que mais se destacaram no debate contra a astrologia. O conteúdo dos seus ataques à astrologia não tinha relação com a cientificidade ou não da astrologia, mas era principalmente uma crítica religiosa e moral, principalmente quanto ao tema do destino e do acaso. Não aceitavam a visão de que a ordem do cosmos pudesse ser produto de uma relação entre necessidade e acaso, independente do plano de Deus, nem as consequências morais da astrologia, que implicavam a negação do livre-arbítrio humano, pois para que ele existisse seria necessário pressupor uma alma racional capaz de ser livre de qualquer influência natural, sejam elas dos "Céus", da pressão dos humores ou do temperamento.

Maquiavel se posicionou do lado dos "cientistas" da época, com seu naturalismo, em oposição aos teólogos e aos humanistas. Portanto, pensamos que a partir da influência deste meio científico (ou pré-científico), destacado por Parel, e pela influência dos valores pagãos e homéricos presentes nas obras literárias e históricas da antiguidade (destacado por Berlin, Ball, Sasso, entre outros), foi se formando a cosmologia trágica de Maquiavel, que estava em oposição à filosofia metafísica e à religião judaico-cristã, como enfatizou Leo Strauss.

Um aspecto trágico da cosmologia maquiaveliana é a ideia de que o cosmos, natural e sem finalidade, está em constante transformação, visão semelhante ao fluxo heraclitiano do devir. Entre outros trechos, essa visão aparece na História de Florença, quando Maquiavel escreve sobre "as coisas deste mundo":

“Costumam as províncias, as mais das vezes, nas mudanças a que são submetidas, da ordem vir à desordem, e novamente, depois, passar da desordem à ordem: porque não estando na natureza das coisas deste mundo o deter-se, quando chegam à sua máxima perfeição, não mais podendo se elevar, convém que precipitem; e de igual maneira, uma vez caídas e pelas desordens chegadas à máxima baixeza, necessariamente não podendo mais 
cair convém que se elevem: assim, sempre do bem se cai no mal e do mal eleva-se ao bem. Porque a virtude gera tranquilidade, a tranquilidade, ócio, o ócio, desordem, a desordem, ruína; e igualmente, da ruína nasce a ordem, da ordem a virtude, e desta, a glória e a prosperidade” (MAQUIAVEL, 1525a, III, p. 229)

Não há em Maquiavel a projeção de uma interrupção final do fluxo do devir. Quanto às formas de governo, nem mesmo a melhor forma de governo possível durará para sempre, e também cairá a seu tempo, pois todos os corpos tem um ciclo natural de nascimento, corrupção e morte $^{252}$. Araújo notou que existe algo de "assustadoramente nietzscheano, pagão e anticristão" nessa visão de Maquiavel de que nem mesmo o melhor governo pode durar para sempre, mas que ao menos poderá deixar a sua marca no mundo (ARAÚJO, 2004, p. 181). Mas se o fluxo do devir não se detém qual é o lugar da iniciativa humana nas ações, que se dão sempre em contextos constrangidos pela necessidade e sujeitos ao acaso, contextos cujas condições não são totalmente conhecidas pelos agentes? Em outras palavras, qual é o lugar do livre-arbítrio no pensamento de Maquiavel? Essas questões são centrais para avaliarmos se Maquiavel pode ser considerado um autor trágico ou não. Para Leo Strauss, como vimos, o florentino não seria trágico porque para ele "o homem é o mestre" (STRAUSS, 1958, 292). Para Skinner, Maquiavel nunca foi tão otimista quanto os outros humanistas cívicos a respeito da capacidade humana de forjar seu próprio destino. Em $O$ Príncipe, Maquiavel não tem uma "visão determinista da condição humana", já nos Discorsi, a fortuna, os céus, o ciclo, ganham peso em relação à virtù humana:

“E, com a perda da fé na força da virtù, a grande tradição do republicanismo italiano foi chegando ao fim. Os começos desse declínio já se podem notar em Maquiavel, ao aceitar a ideia - fatalista, em última análise - de que, apesar dos melhores esforços dos estadistas, existe um ciclo inexorável de crescimento e decadência pelo qual todos os Estados tem que passar. No Príncipe não encontramos sinais dessa visão determinista da condição humana, mas os Discursos começam expondo, no pormenor, essa teoria polibiana dos ciclos inevitáveis” (SKINNER, 1996, p. 207)

\footnotetext{
${ }^{252}$ Maquiavel segue aí a ideia de ciclo, também presente em Políbio: “To Polybius the cycle was a physis, a natural cycle of birth, growth, and death through which republics were bound to pass" (POCOCK, 1975, p. 77)
} 
Para Maquiavel, a iniciativa humana existe, mas é limitada. Permitam-me uma longa e conhecida citação de $O$ Príncipe em que Maquiavel aborda o assunto:

"Não desconheço como muitos tiveram e têm opiniões de que as coisas do mundo são, de certo modo, governadas pela fortuna e por Deus; que os homens com a sua prudência não podem corrigi-las, não havendo, então, remédio algum; e por isso poderiam julgar que não seria necessário cansar-se muito nessas coisas, mas deixar-se governar pela sorte. Essa opinião tem muito crédito em nossos tempos, por causa da grande mudança nas situações que foram vistas e se veem todos os dias, que estão além de toda conjectura humana. Diante do que, pensando eu algumas vezes, inclinei-me de certo modo pela opinião deles. Todavia, para que nosso livre-arbítrio não seja extinto, julgo ser verdadeiro que a fortuna seja árbitra de metade das nossas ações, mas que ela ainda nos deixa governar a outra metade ou quase. E comparo a fortuna com um desses rios danosos que, quando se enfurecem, alagam as planícies, arruínam as árvores e os edifícios, levam terra desta parte e põem-na noutro lugar: qualquer um foge em sua presença, todos cedem ao seu ímpeto sem poder impedi-lo de modo algum. E, ainda que sejam assim, aos homens nada impede que, quando os tempos estão calmos, tomem providências, com proteções e diques: de modo que, ao se avolumarem depois, ou iriam por um canal ou o seu ímpeto não seria nem tão violento nem tão danoso" (MAQUIVEL, 1513, XXV, p. 235) Grifos nossos.

Neste texto do Príncipe, segundo Skinner "mais otimista" que os Discorsi a respeito do alcance da agência humana, Maquiavel afirma que nós governamos "a metade ou quase" de nossas ações, e que chegou a esta conclusão "para que o nosso livre-arbítrio não seja extinto". Não parece ser nenhuma defesa categórica e entusiástica da capacidade humana para determinar o seu próprio destino. Mas não nega essa capacidade. Os trágicos antigos também não negavam. Como procuramos mostrar antes, as tragédias não tratavam apenas do destino, mas do enfrentamento do herói com o destino. Além disso, não estavam ausentes nas tragédias os juízos prudenciais, seja na forma de conselhos para o herói no sentido de evitar a queda - ainda antes da peripécia -, seja no conselho de que, diante do inevitável, o melhor é "abandonar-se", o que também pode ser um juízo prudencial para amenizar o sofrimento. Nesta parte de $O$ Príncipe, Maquiavel atribui grande poder à fortuna, cuja força destrutiva é comparada a de um desastre 
natural, entretanto, o desastre poderia ser evitado ou minimizado se os homens tivessem tomado antes as devidas providências, o que deixa margem para juízos prudenciais.

Nos Discorsi, continua havendo espaço para a iniciativa humana, entretanto, Maquiavel parece dar mais ênfase aos limites dos nossos juízos prudenciais, o que contribui para que seja “impossível ordenar uma república perpétua":

“E como, para semelhantes desordens que surgem nas repúblicas, não é possível prescrever remédio certo, segue-se que é impossível ordenar uma república perpétua, porque sua ruína pode ser causada por mil vias imprevistas" (MAQUIAVEL, 1519a, III, 17, p. 378). Grifos nossos.

A impossibilidade de uma república perpétua, que pusesse termo ao fluxo do devir, já havia sido mencionada no livro I dos Discorsi, e de um modo muito semelhante ao que Maquiavel fez no trecho, já citado, de seu livro posterior História de Florença (1525). Como neste último, nos Discorsi (1519) Maquiavel também escreve que "todas as coisas humanas estão em movimento", mas afirma que "se for possível manter as coisas equilibradas", poderemos ter "verdadeira vida política" (vivere politico) e "verdadeira paz":

“E sem dúvida acredito que, se for possível manter as coisas equilibradas desse modo, ter-se-á verdadeira vida política e verdadeira paz numa cidade. Mas, como todas as coisas humanas estão em movimento e não podem ficar paradas, é preciso que estejam subindo ou descendo; e a muitas coisas a que a razão não nos induz somos induzidos pela necessidade: de tal maneira que, depois de ordenarmos uma república capaz de manter-se sem ampliar-se, se a necessidade a levasse a ampliar-se, seríamos levados a destruir os seus fundamentos e a levá-la mais cedo à ruína. Assim, por outro lado, sempre que o Céu lhe fosse tão benévolo que não lhe cumprisse guerrear, o ócio a tornaria efeminada ou dividida; coisas que, juntas ou cada uma por si, seriam razão para sua ruína". (MAQUIAVEL, 1519a, I, 6, p. 32) Grifos nossos.

Quer dizer, parece haver uma progressiva redução da capacidade humana de forjar o seu próprio destino nas obras O Príncipe (1513), Discursos sobre a primeira década de Tito Lívio (1519) e História de Florença (1525). Mas nem neste último e mais “trágico" livro, ${ }^{253}$ há um ${ }^{253}$ Ridolfi notou que, na sua obra histórica, Maquiavel apresenta de modo mais explícito suas ideias trágicas:
"Tragédias jamais as escreveu, talvez nem cogitou, a não ser essa em que agora estava trabalhando ao se voltar para
questões históricas. Porém ideias trágicas as carregava dentro de si o suficiente para dar àquela sua acusação aos 
fatalismo resignado, na medida em que Maquiavel continua julgando que a história é útil aos cidadãos que governam as repúblicas para que procurem evitar os erros anteriores. ${ }^{254}$

O texto acima exposto dos Discorsi acrescenta outra dificuldade à ideia de uma república perpétua que vai além da noção dos limites do conhecimento humano: a ideia de que ainda que tudo desse certo, e o Céu fosse favorável, o ócio tornaria a cidade "efeminada ou dividida", o que "seria razão para sua ruína", ideia que foi retomada na História de Florença, na parte já citada:

Porque a virtude gera tranquilidade, a tranquilidade, ócio, o ócio, desordem, a desordem, ruína; e igualmente, da ruína nasce a ordem, da ordem a virtude, e desta, a glória e a prosperidade" (MAQUIAVEL, 1525a, III, p. 229)

A sugestão de Parel e Gilbert, que mostramos antes, nos ajuda a compreender esta avaliação do florentino: o conceito de virtù de Maquiavel deve muito ao uso do termo no vocabulário naturalista da medicina, que associava virtù com vitalidade (GILBERT, 1951, pp. 53-55). A vitalidade exigia purgações periódicas e exercício. Esse tipo de associação entre vitalidade, renovação e exercício também estava presente no conceito de virtude dos antigos, o que aparecia com particular força no agonismo. Como procuramos mostrar antes, o agonismo era característico da tradição cultural hegemônica no mundo antigo grego e romano, ainda que entre os filósofos, especialmente nos mais próximos do platonismo, houvesse reserva contra o

príncipes, que não quiseram dar ouvidos à invocação final de $O$ Príncipe, lampejos de drama" (RIFOLFI, 2003, p. 251). Ridolfi sugere que, para Maquiavel, a tragédia da Itália, exposta na História de Florença, poderia ter sido evitada se os príncipes tivessem dado ouvidos "à invocação final de $O$ Príncipe", o que garante espaço aos juízos prudenciais, o que não é incompatível com o ponto de vista trágico, que admite a importância desses juízos, mas aponta seus limites. Em seguida, Ridolfi comenta que Maquiavel começou a escrever a História de Florença com "alguma trágica preocupação", como "entre o trágico e o cômico": "Porém ele, comediógrafo, historiador e autor trágico, não se ocupa agora de comédia, mas de história. Havia começado novamente a escrever não sem alguma trágica preocupação, como entre o trágico e o cômico lemos na correspondência com Guicciardini, 'e estava [ao escrevê-la] muito animado" (RIFOLFI, 2003, p. 256). Vimos que no trágico nietzscheano, a gravidade e a leveza andam juntas, há tragédia e comédia, o que não há é drama moral com acusações contra a vida e projeções de fim da história.

254 "porque se alguma coisa apraz e ensina na história, é a detalhada descrição; se alguma lição é útil aos cidadãos que governam as repúblicas, é precisamente a exposição dos motivos dos ódios e divisões das cidades, a fim de que possam, com outros casualmente tornados sensatos pelos perigos da experiência alheia, manter-se unidos" (MAQUIAVEL, 1525a, Proêmio, p. 31) 
agonismo. Reserva que não se notava nas obras dos poetas épicos, trágicos, cômicos e nos historiadores. A valorização da disputa relacionava-se à ideia de vitalidade. A disputa permitiria que a virtude fosse testada, que surgissem talentos, que a vida se desenvolvesse. Como notou Nietzsche, o "grego não podia carregar a fama sem a continuação da disputa, nem a felicidade no final da disputa" (NIETZSCHE, 1872a, p. 75). Isso significa que a vitalidade exige superar resistências, pressupõe tensão, exercício. Para Maquiavel, se a república tem sucesso ela produz virtude, mas "a virtude gera tranquilidade, a tranquilidade, ócio, o ócio, desordem, a desordem, ruína”.

A ideia de que a virtù precisa ser testada, que a vitalidade requer exercício, superação de resistência, também aparece quando Maquiavel, no início dos Discorsi, escreve sobre o local ideal para a fundação de uma cidade, e propõe a questão de saber se é melhor fundá-la em terreno estéril ou fértil e levanta a possibilidade de que talvez seja melhor em terreno estéril:

"E, como os homens agem por necessidade ou por escolha, e como se vê que é maior a virtù onde haja menos escolhas, é de pensar que, para a edificação das cidades, talvez fosse melhor escolher lugares estéreis, para que os homens, obrigados a esforçar-se e a ocupar-se menos com o ócio, vivessem mais unidos por terem menos razões de discórdia, em vista da pobreza do local” (MAQUIAVEL, 1519a, I, 1, p. 10)

O terreno estéril obrigaria os cidadãos ao esforço, afastaria o ócio e os manteria unidos. Em seguida, Maquiavel defende que é melhor escolher um lugar fértil, “desde que os efeitos da fertilidade sejam limitados por leis” (MAQUIAVEL, 1519a, I, 1, p. 11), e, mais uma vez , a acomodação é vista como corruptora, e a tensão - desta vez promovida pelas leis ditadas por "Rômulo, Numa e outros"-, é considerada como produtora de virtù:

“seja qual for o modo considerado, verá que Roma teve um princípio livre, sem depender de ninguém: verá também, como diremos adiante, a quantas necessidades as leis ditadas por Rômulo, Numa e outros a obrigaram, de tal modo que a fertilidade do solo, a comodidade do mar, as numerosas vitórias e a grandeza do império não a puderam corromper durante muitos séculos, mantendo-a cheia de tanta virtù, com que nenhuma outra cidade ou república jamais se ornou” ( MAQUIAVEL, 1519a, I, 1, p. 12) 
As boas leis, necessárias para uma república bem ordenada e para a paz, por sua vez, derivam de situações extraordinárias, como os tumultos entre a plebe e a nobreza, que, segundo Maquiavel, eram causa das leis que protegiam a liberdade:

"porque os bons exemplos nascem da boa educação; a boa educação, das boas leis; e as boas leis, dos tumultos que muitos condenam sem ponderar (...)” (MAQUIVEL, 1519a, I, 4, p. 22)

Mas as situações extraordinárias não foram necessárias apenas no momento inicial de fundação, senão que devem ser periodicamente repetidas, para evitar a decadência do corpo político. É de se notar que na discussão sobre a necessidade da refundação contínua apareçam termos como "vida", “corpo", “corpos mistos", "saudável”:

"A grande verdade é que todas as coisas do mundo têm seu tempo de vida; mas as que seguem todo o curso que lhes é ordenado pelo céu geralmente são aquelas cujo corpo não se desordena, mas se mantém de modo ordenado, sem alterações, ou, se as houver, com alterações que o tornem saudável, e não o danifiquem. E como estou falando de corpos mistos, como as repúblicas e as seitas, digo que são saudáveis as alterações que as levam de volta aos seus princípios. Portanto, são mais bem ordenadas e têm vida mais longa aquelas que, mediante suas ordenações podem renovar-se muitas vezes, ou que, por algum acontecimento independente de tal ordenação, procedem a tal renovação. E é mais claro que a luz o fato de que, não se renovando, tais corpos não duram” (MAQUIAVEL, 1519a, III, 1, p. 305)

Em seguida, ainda no mesmo capítulo dos Discorsi, Maquiavel explicitamente utiliza o vocabulário da medicina e compara os corpos com as repúblicas:

"E, como, com o passar do tempo, essa bondade se corrompe, esse corpo haverá de, necessariamente, morrer, se nada ocorrer que o reconduza às condições iniciais. E os doutores de medicina dizem, falando dos corpos humanos, 'quod quotidie aggregatur aliquid, quod quandoque indiget curatione' [Que todos os dias se acrescenta alguma coisa que, um dia ou outro, precisará de tratamento]. Essa recondução ao princípio, em se tratando das repúblicas, pode ocorrer por acontecimento extrínseco ou por prudência intrínseca. Quanto ao primeiro caso, era necessário que Roma fosse tomada pelos franceses, para renascer e, renascendo ganhar nova vida e nova virtù" (MAQUIAVEL, 1519a, III, 1, p. 306)

Maquiavel comenta que as repúblicas podem retornar ao princípio por acontecimento 
“extrínseco" ou por "prudência intrínseca" e cita o exemplo de Roma, que precisou ser tomada pelos franceses, "para renascer e, renascendo ganhar nova vida e nova virtù". Mais uma vez, aparece o termo vida e a virtù se confunde com vitalidade, sendo excitada pela resistência, no caso, representada pelos invasores franceses.

Segundo Maquiavel, para que dure mais tempo, sem que isso signifique eternidade, as instituições da República devem ser capazes de renovação contínua, devem ser capazes de retornar ao princípio periodicamente ${ }^{255}$, mas este retorno ao princípio, é o retorno à situação extraordinária, ao "estado de exceção", ao terror e medo originais, que parecem ter um efeito catártico:

“A propósito, os homens que governaram o estado de Florença de 1434 até 1494 diziam que seria necessário retomar o estado a cada cinco anos, caso contrário, seria difícil mantê-lo: e por retomar o estado entendiam disseminar entre os homens o terror e o medo que haviam disseminado ao tomá-lo, quando abateram todos os que, segundo aquele modo de vida, se haviam condizido mal" (MAQUIAVEL, 1519a, III, 1, p. 308)

Como notou Leo Strauss, o "retorno ao princípio" não significa recriar as mesmas leis e ordenações que existiam no princípio, mas apenas o retorno à situação extraordinária original, e este movimento sempre levaria à criação de novas leis e ordenações, em uma espécie de eterno retorno do diferente:

"The renovation of mixed bodies consists of the renewal of fear in the minds of their members or of putting in men that terror and that fear which the original founders had put into their partisans. This, and not the return to the old modes and orders, is the essence of the return to the beginning. Return to the beginning means in all cases introducing new orders. Therefore in particular Machiavelli's return to the ancient modes and orders means of necessity the devising of new modes and orders. Ordinary return to the beginning means return to the terror accompanying the foundation" (STRAUSS, 1958, p. 167) Grifos nossos.

Maquiavel pressupõe que a acomodação produzida por uma estabilidade muito longa 255 "Portanto, é de crer que Mânlio fosse obrigado a proceder com tanta rigidez por seus comandos extraordinários,
aos quais era inclinado por natureza, o que é útil numa república, porque faz que suas ordenações se voltem para o
seu princípio, para sua antiga virtù. E seria perpétua a república que fosse tão feliz que tivesse, frequentemente -
conforme acima dissemos -, alguém que, com seu exemplo, lhe renovasse as leis, e não só a mantivesse com o fito
de evitar a ruína, mas a fizesse voltar às origens." (MAQUIVEL, 1519a, III, 22, p. 391) Grifos nossos. 
leva a um crescimento da corrupção e à decadência, e, ainda que isto possa não parecer "racional", na sua avaliação, os homens precisam de situações extraordinárias com seus efeitos catárticos para que recuperem a virtù, a sua compreensão da importância do Estado, do respeito a lei e para renovar o seu amor à pátria. O título do capítulo 16, do livro III dos Discorsi, não poderia ser mais explícito acerca dessa ideia: "Em tempos difíceis, tem-se que recorrer à virtude verdadeira; mas quando tudo vai bem, sobressaem os homens ricos e de família influente, e não os homens virtuosos" (MAQUIAVEL, 1519b, p. 353) ${ }^{256}$. Uma avaliação parecida com a que terá Thomas Jefferson quando disse que seria necessária “uma revolução a cada geração" para evitar a esclerose cívica ${ }^{257}$.

Portanto, o obstáculo a uma república perene não é derivado apenas dos limites do conhecimento dos agentes, da pouca informação nos seus juízos prudenciais, mas do próprio sucesso da república, que produz estabilidade, e com ela, acomodação, a perda de virtù e a decadência. Como todo organismo, a república precisa de purgações periódicas e exercício, para uma vida mais longa e saudável. Essa avaliação de Maquiavel não é apresentada por ele como uma preferência normativa sua, mas como derivada da natureza dos corpos. Haveria, para o florentino, uma legalidade natural dos corpos políticos que limita, sem contudo eliminar, o papel da agência humana na produção de seu próprio destino. A possibilidade de escolher a nãorenovação, por exemplo, é excluída, já que para prolongar a existência e saúde do corpo político impõe-se a necessidade de renovação contínua, necessidade que é contrária a uma tendência espontânea dos organismos de permanecerem na acomodação já conquistada. Por esse motivo, o retorno ao princípio, a renovação contínua, nem sempre é fácil, e é mais frequente que a renovação derive de "causas extrínsecas", como disse Maquiavel a respeito da renovação da

\footnotetext{
${ }^{256}$ No original: "Che la vera virtu' si va ne' tempi difficili, a trovare; e ne' tempi facili, non gli uomini virtuosi, ma quegli che per ricchezze o per parentado hanno piu' grazia".

257 "The greatest danger to the new American Republic was that it would grow old and feeble and infirm. Its citizens and leaders could lose their nerve and their love of the new, and settle comfortably into their dotage. To postpone such civic sclerosis, Jefferson advocates a number of strategies. The most radical of these was to have a revolution every generation" (APPLEBY \& BALL, 1999, Introduction)
} 
virtù produzida em Roma pela invasão dos franceses ${ }^{258}$.

Em O Príncipe, Maquiavel havia escrito que para "salvar o nosso livre-arbítrio", considerava que nós governamos "a metade ou quase" do nosso destino. Como vimos, Skinner considerou que o papel da agência humana no Príncipe era maior que nos Discorsi, e isto é visível nesta frase do florentino sobre "a metade ou quase" que cabe ao nosso livre-arbítrio. Mas não quer dizer que na metade que nos cabe existiria um "eu racional" totalmente livre de qualquer determinação para escolher os fins e os meios nas suas ações. Isso nos leva a outro aspecto do trágico duelo entre a virtù e a fortuna, pois além virtù ser condição necessária, mas não suficiente, para obter sucesso político, a própria virtù não é algo que dependa somente de uma livre escolha ou mesmo de um aprendizado para escolher bem, pois além dos constrangimentos externos, independentes da vontade individual, a própria vontade individual é vista como determinada pela natureza do indivíduo e por sua educação. Physis e nomos, para usar os termos dos antigos trágicos gregos. A liberdade de escolha seria na melhor das hipóteses a liberdade do indivíduo agir de acordo com sua "estrutura humoral" ou temperamento, na pior das hipóteses seria uma ilusão. ${ }^{259}$

Para Maquiavel, como para os antigos trágicos, e mesmo para Aristóteles, não existe algo como uma consciência humana livre para escolher seu próprio temperamento, nem é esta consciência uma tábula rasa, cujos conteúdos seriam totalmente provenientes do meio social. Segundo Maquiavel, tanto a natureza quanto o meio social contribuem para a conformação de uma personalidade, e, uma vez estabilizada essa personalidade, não há mais uma flexibilidade

\footnotetext{
${ }^{258}$ A tendência à acomodação, bem como a limitada flexibilidade das personalidades, dificultam a renovação contínua por causas intrínsecas: "A reforma parcial e sucessiva deve ser provocada por um homem esclarecido que saiba reconhecer de muito longe as dificuldades, logo que surjam. É possível que nunca se encontre um homem deste tipo; se surgisse um só, não conseguiria jamais convencer os concidadãos dos vícios identificados pela sua previsão. Quando estão habituados a uma certa maneira de viver, os homens não a querem alterar, sobretudo se não enxergam claramente o mal que se lhes insinua" (MAQUIAVEL, 1519b, I, 18, p. 77)

259 "Quando Maquiavel divisa a possibilidade de tomar decisões livres, ele não subentende de nenhuma forma uma instância exterior ao curso da natureza; a vontade é tão condicionada por fatores naturais, os instintos, as tendências naturais contra as quais ninguém pode agir como a queda de uma pedra é determinada por seu peso (...) O homem é um pedaço da natureza e não pode de nenhuma forma se livrar de suas leis". HORKHEIMER, Max. Les débuts de la philosophie bourgeoise de l'histoire. Paris: Payot, 1974, p. 34. Citado em: ARANOVITCH, 2007, p. 91.
} 
tão grande para mudanças de conduta, o que pode fazer com que surja uma discrepância entre o temperamento de um líder e a necessidade "dos tempos", que exigiria uma determinada conduta. Esta discrepância seria um dos principais motivos para a ruína desse líder, adicionando mais uma dimensão trágica para o duelo entre virtù e fortuna ${ }^{260}$. Para Maquiavel, a natureza humana, possuiu variações individuais, e pode ser mais ou menos moldada pela educação, entretanto, nenhuma educação, nem a pagã nem a cristã ou outra, eliminaria completamente a natureza. Como é conhecido, para Maquiavel essa natureza humana era amoral (como toda natureza), e seria, ao mesmo tempo, egoísta, competitiva, insaciável, mas também capaz de solidariedade e de atos virtuosos.

Um exemplo de como Maquiavel entendia a força das tendências naturais na conformação de uma personalidade aparece na biografia que fez de Castruccio Castracani. Segundo a narração de Maquiavel, Castruccio nasceu em condições difíceis e ainda bebê foi abandonado, tendo sido encontrado em um cesto por uma senhora chamada Dianora, que era irmã do cônego Antônio Castracani e vivia com ele. Os dois criaram o pequeno Castruccio como se fosse seu filho e lhe deram sólida formação religiosa, com o objetivo de formá-lo sacerdote. Entretanto, o jovem era "de todo diferente do ânimo sacerdotal", e, quando chegou aos catorze anos de idade, "pôs de lado os livros eclesiásticos e começou a tratar das armas", e só queria saber de correr, saltar, manejar armas, e nesses exercícios demonstrava "grandíssimo valor de espírito e de corpo", o que provocava no seu padrasto "dor e aborrecimento inestimável” (MAQUIAVEL, 1520b, pp. 13-18). Até que em certa ocasião o senhor Francesco Guinigi, líder militar gibelino, observa os exercícios do jovem Castruccio e o chama para se unir a ele e

\footnotetext{
${ }^{260}$ A limitada flexibilidade da personalidade seria uma das razões para que Maquiavel considerasse as repúblicas como tendo mais vida e sendo mais duradouras que as monarquias: "Por isto a sorte dos homens varia: a sorte altera os tempos, mas nem todos modificam sua conduta.(...) Por isto, as repúblicas possuem mais germes de vida, e têm sorte mais duradoura do que as monarquias; elas podem mais facilmente acomodar-se à variedade das circunstâncias do que um monarca absoluto, dada a diversidade de cidadãos que as compõem. $O$ homem acostumado a agir de um só modo nunca muda, conforme já observei; se o tempo obrigar a alterações de conduta contrárias a seus hábitos, perecerá” (MAQUIAVEL, 1519b, III, 9, p. 336). Grifos nossos.
} 
receber treinamento militar. O padrasto permite e Castruccio torna-se soldado e chega a ser adotado por Francesco, tornando-se seu herdeiro político e tutor de seu filho. Quer dizer, apesar da educação religiosa e da intenção do padrasto, a tendência natural de Castruccio o levou a outro caminho. Para Maquiavel, existem algumas virtudes que são "naturais" nos indivíduos ${ }^{261}$.

O destino de Castruccio foi fruto de uma combinação de acasos que permitiram que ele realizasse sua natureza, o que facilitou seu sucesso e permitiu que sua história se tornasse digna de ser contada a todos aqueles que "com ações virtuosas se deleitam" (MAQUIAVEL, 1520b, p. 14). Essa concepção de liberdade, diferente do livre-arbítrio da tradição cristã e humanista, é uma gaia liberdade, entendida como aceitação da necessidade, como realização de uma natureza, como o desenvolvimento de uma potencialidade imanente.

Ainda sobre a relação entre tendências naturais, personalidade e escolha, há um momento em que Maquiavel relaciona as diferenças dos juízos (giudizio) e desejos (appetiti) com a diferença das forças ou vigor (forze) na juventude e na velhice, ou seja, em última instância, as perspectivas diferentes sofrem influência do ciclo natural do corpo, e este seria um dos motivos para que o julgamento dos anciões sobre os fatos passados, segundo Maquiavel, nem sempre fosse "razoável":

"Isso seria verdadeiro se, em todos os momentos da vida, os homens tivessem o mesmo tipo de julgamento e os mesmos desejos; mas, variando estes, mesmo quando os tempos não variam, os homens não podem ter dos tempos as mesmas impressões, visto terem desejos, predileções e considerações diferentes na velhice e na juventude. Porque, se à medida que os homens envelhecem lhes minguam as forças e crescem-lhes o juízo e a prudência, é inevitável que as coisas que na juventude lhes pareciam suportáveis e boas acabem por mostrar-se insuportáveis e ruins à medida que envelhecem; e, em vez de acusarem seu modo de julgar, acusam os tempos. Além disso, visto que os apetites humanos são insaciáveis, porque, tendo os homens sido dotados pela natureza do poder e da vontade de desejar todas as coisas e pela fortuna de poder conseguir poucas, o resultado é o contínuo descontentamento nas mentes humanas e o fastio das coisas possuídas: o que leva a condenar os tempos presentes,

261 "Como acontece entre os homens, há também cavalos de pouca coragem e cavalos impetuosos” (MAQUIAVEL, 1519 b, II, 18, p. 249). 
a louvar os tempos passados e a desejar os tempos futuros, mesmo que a isso não sejam movidos por nenhum motivo razoável” (MAQUIAVEL, 1519a, II, introdução, p. 180). Grifos nossos.

Em carta a seu amigo Vettori, o tema da influência de tendências "naturais" sobre os juízos aparece novamente. Maquiavel diz a seu amigo que suas divergências na análise política da situação da Lombardia deviam-se aos seus diferentes "sentimentos naturais" e temperamento"262. Mais tarde, Espinosa dirá que nós "não sabemos o que pode um corpo"²63. Nietzsche, e os que estão no ponto de vista trágico, seguirão pensando sobre a relação entre perspectiva e corpo, entre representação e fisiologia. Alliez destaca que para o Deleuze, "o ponto de vista está no corpo" (ALLIEZ, 2000, p. 437). No trecho acima citado dos Discorsi, o vigor ou o cansaço afetam as perspectivas e escolhas dos indivíduos, e, quando variam nossos apetites, mesmo que os tempos não mudem, acusamos os tempos.

Em seguida, no mesmo trecho citado, Maquiavel relaciona a acusação dos anciões contra "os tempos" com a insaciabilidade dos apetites humanos, o que remete ao tema da vontade, entendida em uma perspectiva naturalista, como puro querer, estando, portanto, na esfera do desejo. Como dizia Aristóteles, “é da natureza do desejo não ter limites e a maioria dos homens vive somente para satisfazer seus desejos". ${ }^{264}$ A afirmação de Aristóteles é feita quando ele

262 "I suspect that your not wanting it [a particular proposal for peace in Europe] and my wanting it have the same basis - a natural feeling or temperament that causes to say 'no' and me to say 'yes'. You justify your 'no' by pointing out that, were the king to regain Lombardy, there would be more difficulty in achieving peace; to justify my 'yes', I have pointed out that this is not true - furthermore, peace gotten by my method will be more secure and more stable". Grifos nossos. MAQUIAVEL, em carta a Vettori citada em: VIROLI, 1998, p. 70.

263 "O fato é que ninguém determinou, até agora, o que pode o corpo, isto é, a experiência a ninguém ensinou, até agora, o que o corpo - exclusivamente pelas leis da natureza enquanto considerada apenas corporalmente, sem que seja determinado pela mente - pode e o que não pode fazer (...) Disso se segue que, quando os homens dizem que esta ou aquela ação provém da mente, que ela tem domínio sobe o corpo, não sabem o que dizem, e não fazem mais do que confessar, com palavras enganosas, que ignoram, sem nenhum espanto, a verdadeira causa dessa ação (...) Ensina também que as decisões da mente nada mais são do que os próprios apetites: elas variam, portanto, de acordo com a variável disposição do corpo (...) Aqueles, portanto, que julgam que é pela livre decisão da mente que falam, calam, ou fazem qualquer outra coisa, sonham de olhos abertos" (SPINOZA, 2008, p. 167-171).

264 "A igualização das propriedades entre os cidadãos é sem dúvida um dos fatores suscetíveis de contribuir para evitar revoluções; não é, porém, um dos mais importantes, pois os membros das classes superiores se ressentiriam, argumentando que seus méritos não são iguais aos dos componentes das classes inferiores; por isto os vemos com frequência atacando o governo e rebelando-se; também a cupidez humana é insaciável, e embora inicialmente um subsídio de dois óbolos fosse bastante, quando este se tornou um direito adquirido as pessoas passaram a querer cada vez mais, sem nunca chegarem a um limite (o desejo por sua própria natureza não tem limites, e a maioria dos homens vive para sua satisfação)". (ARISTÓTELES. Política, 1267b, p. 53), Grifos nossos. 
explicava que a "cupidez humana" (pleonexia) seria insaciável e era causa do conflito entre as classes. Maquiavel faz afirmação semelhante a respeito da natureza humana, vista também como movida pelo desejo, e este como origem das dissensões:

"De fato, a natureza criou os homens com a sede de tudo abraçar e a impotência de atingir todas as coisas. Como o desejo de possuir é mais forte do que a faculdade de adquirir, disto resulta um secreto desgosto pelo que possuem, ao qual se junta o descontentamento por si próprios. Esta é a origem dos seus variados destinos. Uns querem possuir mais, outros temem perder o que já ganharam; daí o atrito e a guerra, que por sua vez provocam a destruição de um império para servir à elevação de outro. Inspira este comentário o comportamento do povo romano ao criar a instituição dos tribunos para se opor às pretensões da nobreza. Mal esta medida (que respondia a uma necessidade efetiva) foi concedida, o povo recomeçou o combate à nobreza, almejando partilhar suas riquezas e honrarias - os dois bens mais cobiçados” (MAQUIAVEL, 1519b, I, 37, p. $121)^{265}$

Maquiavel retoma o antigo tema da pleonexia, a ambição ilimitada, e chegou a esta reflexão não apenas por meio da leitura das obras dos antigos que enfrentaram a questão (entre eles Platão e Aristóteles), mas também como resultado da sua compreensão da natureza humana sem o apoio de uma teleologia e sem dualismo. Frente a pleonexia, Maquiavel não mobiliza uma "razão" de origem externa ao corpo capaz de lhe dar normatividade interna, tampouco há uma finalidade moral única que se imponha aos indivíduos. Resta que é o desejo que impulsiona os indivíduos e é responsável pelos conflitos entre homens, que lutam entre si não por "maldade", mas por que os desejos são variados e os homens podem tornar-se adversários na consumação dos desejos.

Leo Strauss destacou que em Maquiavel não existe a perspectiva de superar a esfera do desejo. Segundo Strauss, o maior propósito de Maquiavel é "mostrar a necessidade de levar em conta os desejos egoístas dos governantes e dos governados como a única base natural da

\footnotetext{
${ }^{265}$ Nesse texto, parece claro que Maquiavel não idealiza o povo como podemos ser levados a pensar a partir da interpretação de McCormick, pois também a plebe também movia-se pela pleonexia.
} 
política"266, e a arte política consiste em direcionar as paixões para o bem comum $^{267}$. Como vimos, Skinner enfatizou que, para Maquiavel, a república deve estar organizada de modo a produzir um "equilíbrio tenso entre forças sociais opostas" (SKINNER, 1981, p. 103) $)^{268}$. Isso porque, não podendo ser eliminada a pleonexia, resta impedir que ela se intensifique a tal ponto que a stasis (conflito civil) destrua a cidade ${ }^{269}$.

O equilíbrio tenso é produzido por meio de um arranjo institucional que mobiliza um humor contra o outro, "ambição contra ambição", e impede que um dos lados da cidade, ou um indivíduo, cheguem à preponderância inconteste. Nas palavras de Skinner, "embora inteiramente motivadas por seus interesses egoístas, as facções serão assim levadas, como que por uma mão invisível, a promover o interesse público” (SKINNER, 1981, p. 103). Isso não significa que Maquiavel considere que todo conflito social seja positivo para a liberdade, mas apenas aqueles que são canalizados institucionalmente ${ }^{270}$, de modo a que existam "válvulas de escape para a paixão" ${ }^{971}$ e que nenhuma das partes da cidade consiga destruir a outra ${ }^{272}$. Roma teria alcançado

266 "To the extent to which Machiavelli's two books are meant for immediate prudent use rather than for rendering secure the basis of prudence, their broad purpose is to show the need for reckoning with the selfish desires of rulers and the ruled as the only natural basis of politics" (STRAUSS, 1958, p 282) Grifos nossos.

267 "The task of the political art consists therefore in so directing the passions and even the malignant humors that they cannot be satisfied without their satisfaction contributing to the common good or even serving it" (STRAUSS, 1958, p. 281)

268 "A solução, argumenta Maquiavel, consiste em organizar as leis relativas à constituição de modo a produzir uma relação de equilíbrio tenso entre essas forças sociais opostas, na qual cada uma das partes permanece envolvida com os negócios do governo, e cada uma 'mantém a outra sob vigilância' para impedir tanto 'a arrogância do rico' quanto a 'licenciosidade do povo' (...) Embora inteiramente motivadas por seus interesses egoístas, as facções serão assim levadas, como que por uma mão invisível, a promover o interesse público em todos os seus atos legislativos: 'todas as leis feitas em favor da liberdade' irão resultar de sua discórdia"' (SKINNER, 1981, p. 103).

${ }^{269}$ Neste ponto, Strauss e Skinner estão do mesmo lado, pois entendem que, para o florentino, o egoísmo humano não pode ser eliminado, mas pode ser moldado de um modo que favorável ao bem comum.

270 "porque as inimizades que no início surgiram em Roma entre o povo e os nobres definiram-se discutindo, e em Florença, combatendo; as de Roma com a lei, as de Florença, com a morte e com o exílio de muitos cidadãos terminaram" (MAQUIAVEL, 1525a, III, 1, p. 143)

${ }^{271}$ Nos Discorsi, o direito de acusação pública, desde que submetido a regras e provas para evitar calúnias, era entendido como válvula de escape à paixão: "Esta medida tem, numa república, dois efeitos extremamente importantes: o primeiro é que os cidadãos, temendo ser acusados, não ousam investir contra a segurança do Estado; se tentam fazê-lo, recebem imediatamente o castigo merecido. O outro é o de se constituir numa válvula de escape à paixão que, de um modo ou de outro sempre fermenta contra algum cidadão. Quando esta paixão não encontra um meio legal de vir à superfície, assume uma importância extraordinária, que abala os fundamentos da república" (MAQUIAVEL, 1519b, p. 41). Grifos nossos.

272 "Disto ainda procedia que, com as vitórias do povo, a cidade de Roma mais virtuosa se tornava; porque este povo podendo participar da administração das magistraturas dos exércitos e dos impérios juntamente com os nobres prepostos, da mesma virtude que nestes havia, se impregnava; e a cidade, acrescida de virtude, crescia em potência. 
esse arranjo positivo para a liberdade. Florença não, especialmente por que nela, não eram os legítimos conflitos entre humores de classe que prevaleciam, mas conflitos entre facções/partidos $($ sètte $) .{ }^{273}$

O que queremos enfatizar é que, na perspectiva de Maquiavel, o equacionamento dos conflitos civis, para evitar a stasis violenta, só pode se dar no interior da esfera do desejo. Como vimos, Maquiavel destaca dois desejos principais, o desejo de "não ser oprimido" e o desejo de "comandar", e identifica estes dois desejos com as duas partes diferentes da cidade, "os grandes" e o "povo" 274 . No capítulo anterior procuramos mostrar que a partir desta teoria dos dois humores, e do modo institucional e legal de encaminhar o conflito civil, Skinner, Viroli e Pettit concluíram que Maquiavel seria um partidário da liberdade como "não-dominação", que entendia a liberdade positiva como instrumental para defender a liberdade negativa. A liberdade seria a ausência da possibilidade de interferência arbitrária, e seria garantida por um arranjo institucional-legal derivado de um encaminhamento bem ordenado dos conflitos civis. Também a partir da teoria de Maquiavel sobre o conflito civil, McCormick concluiu que o povo é o "guardião da liberdade". McCormick não concordava com o acento da Cambridge School na "neutralização" do conflito, e não considerava que Maquiavel pensasse os dois humores, da plebe e dos nobres, como igualmente perigosos em seus excessos. Para McCormick, como vimos, Maquiavel defendia uma república com prevalência popular, e McCormick também entendia a liberdade como não-dominação, como notou Silva (SILVA, 2010, p. 53), na medida

Mas em Florença, quando saía vencedor o povo, ficavam os nobres despojados de magistrados" (MAQUIAVEL, 1525a, III, 1, p. 143-4)

273 "Mas antes de tudo desejo, discorrendo segundo é meu costume, afirmar que aqueles que esperam que uma república possa ser unida, muito se equivocam nessa esperança. Na verdade, algumas divisões as prejudicam, outras as beneficiam; as que as prejudicam nascem junto aos partidos e partidários, as que as beneficiam, se mantêm sem estes nem aqueles. Então o fundador de uma república, não podendo impedir que nela existam inimizades, pelo menos deve providenciar que não existam partidos" (MAQUIAVEL, 1525a, VII, 1, p. 329)

${ }^{274}$ Já citamos o trecho em O Príncipe sobre os dois humores, mas Maquiavel também expõe o assunto nos Discorsi e na História de Florença: "As graves e naturais inimizades que existem entre as pessoas do povo e os nobres, causadas porque estes querem mandar e aquelas não querem obedecer, são os motivos de todos os males que surgem nas cidades, porque desta diversidade de humores nutrem-se todas as outras coisas que perturbam as repúblicas" (MAQUIAVEL, 1525a, III, 1, p. 143) 
em que identificou o povo como "guardião da liberdade", e o humor do povo consiste "em não querer ser oprimido".

Independente do mérito das preferências normativas destes comentadores, sentimos dificuldade em incluir Maquiavel, sem mais, na perspectiva da liberdade como não-dominação, pois não vemos em sua obra nenhuma demonstração de simpatia pelo simples "desejo de não ser oprimido", antes o contrário, temos muitas demonstrações de que o que mais o agradava eram os "grandes empreendimentos", a vida ativa, o querer comandar, imprimir forma. Preferências que também são destacadas nas biografias escritas por Ridolfi e Viroli que citamos antes. O querer comandar, influir, participar, obter glória, é constitutivo da liberdade positiva, enquanto o desejo de segurança é mais afim com a liberdade negativa. Maquiavel escreve que apenas uma minoria quer a liberdade para comandar ${ }^{275}$, mas em nenhum momento diz que a liberdade consistiria apenas em viver em segurança. Não podemos esquecer que Maquiavel dedica boa parte da sua obra para a análise do papel da liderança política. Para o florentino, a liderança é a força inovadora da sociedade, e o povo é a sede da moralidade e da religião. A resistência conservadora é importante para moderar a inovação, mas se prevalecesse apenas essa tendência à acomodação a renovação contínua necessária para a saúde da república seria limitada. Por esse motivo, segundo Maquiavel, os príncipes são superiores para introduzir novos ordenamentos, e o povo superior na manutenção dessas inovações, e erra menos que os príncipes:

"E, se os príncipes são superiores aos povos na ordenação das leis, na constituição da vida civil, no estabelecimento de novos estatutos e novas ordenações, os povos também são superiores na manutenção das coisas ordenadas, aumentando assim, sem dúvida, a glória daqueles que as ordenam. Em suma, para concluir esta matéria, digo que, assim como duraram muito os estados dos príncipes, também duraram os estados das repúblicas, e que ambos precisam ser regulados por leis, porque o príncipe que pode fazer o que quer é louco; um povo que pode fazer o que quer não é sábio. Se, portanto, pensarmos num príncipe vinculado às leis e num povo acorrentado a elas,

275 "Uma pequena parte do povo deseja ser livre para comandar, mas um número infinitamente maior de cidadãos querem ter a liberdade apenas para poder viver em segurança” (MAQUIAVEL, 1519b, I, 16, p. 71). 
veremos mais virtù no povo que no príncipe; e, se pensarmos em ambos irrefreados, veremos menos erros no povo que no príncipe, sendo tais erros menores e mais remediáveis” (MAQUIAVEL, 1519a, I, 58, p. 171) ${ }^{276}$

Tampouco consideramos convincente considerá-lo como seguidor de uma concepção de vida boa desinteressada e harmônica, em razão do seu ceticismo quanto a possibilidade de superar a pleonexia. Para Maquiavel, os homens por natureza precisam uns dos outros, mas também por natureza são "antagonísticos" uns com os outros, e "não podemos dizer qual destas duas necessidades opostas é mais natural" (STRAUSS, 1958, p. 280). Para considerarmos Maquiavel inequivocamente como um partidário da liberdade como não-dominação deveríamos encontrar declarações explícitas do florentino condenando a dominação, a grandeza e a conquista, mas, em vez disso, encontramos que, para ele, o desejo de conquistar não é condenável, mas "coisa muito natural":

“É verdadeiramente coisa muito natural e ordinária desejar conquistar: e sempre quando os homens o fazem e podem serão louvados ou não censurados; porém, quando eles não podem, e desejam fazê-lo de todo modo, aqui está o erro e a censura. Portanto, se a França pudesse com as suas forças assaltar Nápoles, deveria fazê-lo" (MAQUIAVEL, 1513, III, p. 53).

Maquiavel considera que o desejo de conquista é natural e louvável. Maquiavel não condena o desejo do cidadão conquistar glória, nem condena as conquistas da pátria em direção à grandeza. Sua valorização positiva da conquista também aparece, em outra forma, em suas suas comédias, Mandrágora e Clízia.

Na Mandrágora, Calímaco é excitado a tal ponto pelo desejo de conquistar a bela Lucrécia que arma um plano mirabolante, que envolve enganar o marido de Lucrécia, Messer Nícia, que quer muito ter um filho, mas é estéril. Calímaco se faz passar por médico e sugere

\footnotetext{
${ }^{276}$ Leo Strauss comenta esse capítulo dos Discorsi: "The people is the repository of the established, of the old modes and orders, of authority. Therefore one may provisionally say that the peoples are by far superior to princes in glory. But however this may be, one must say with finality that the peoples are by far superior to princes in goodness; for goodness or morality is essentially preserving or conservative, and not innovating or revolutionary, whereas the prototype of princes is Romulus the fratricide. The peoples are repository of morality. After all that has been said this does not mean that peoples always act morally or even that they are fundamentally moral; belief in morality is not yet morality (...) At any rate, for the same reason for which the peoples are the repository of morality, they are also the repository of religion" (STRAUSS, 1958, p. 130-1).
} 
uma poção de Mandrágora como tratamento para permitir a gravidez, entretanto, avisa que o primeiro homem que tiver relações sexuais com ela após a ingestão da poção poderá morrer dentro de oito dias, e sugere a Nícia que encontre alguém, um mendigo talvez, disposto a ter relações com Lucrécia arriscando sua própria vida. Nícia, tomado pelo seu desejo de ter descendente, aceita a proposta. E é Calímaco que irá ao leito de Lucrécia disfarçado de mendigo, sem que Nícia saiba que é ele. Faltava convencer a relutante e religiosa Lucrécia, e quem a persuade é o Frei Timóteo, em troca de bom pagamento ${ }^{277}$. Pouco antes da consumação do plano, Calímaco exibe preocupação com o seu sucesso: “Em que angústia d'alma estive e estou! E é verdade que o fado e a natureza mantêm sempre em equilíbrio as contas do balanço: nunca nos fazem um bem que, de encontro não surja um mal”278 (MAQUIAVEL, 1518, p. 119), e, Calímaco pensa consigo mesmo, “o pior que pode acontecer é morrer e ir para o inferno. Mas já morreu tanta gente! E estão no inferno tantos homens de bem! ${ }^{279}$ Deverás, porventura, envergonhar-te de lá ires também? Arrosta o destino; foge o mal, mas se não podes fugi-lo, suporta-o como homem; não te prosternes" ${ }^{280}$ (Id). Depois de consumado o ato, Lucrécia pede para que Calímaco retorne mais vezes. Calímaco conquistara Lucrécia ${ }^{281}$.

Nem na política, nem na guerra e nem no amor o desejo de conquistar é condenado por Maquiavel. É forçado explicar a sua preferência pelo modelo popular e expansionista romano

\footnotetext{
277 “Oh, frades! Quem conhece um, conhece-os todos” (Calímaco, em MAQUIAVEL, 1518, p. 131)

${ }^{278}$ A ideia de que não há um bem que não traga consigo também um mal era comum nas tragédias, como tentamos mostrar antes, e aparecia nas situações trágicas de colisão entre bem e bem.

${ }^{279}$ Esse pensamento de Calímaco lembra um episódio citado Ridolfi e por Viroli. Contam os biógrafos que Maquiavel, nos seus últimos dias, falou aos seus amigos sobre um sonho que teve em que um grupo de homens mal vestidos e de aparência sofredora dizem "Somos os santos e os bem-aventurados, vamos para o paraíso", e, depois que eles vão embora, apareceram outras pessoas de nobre aspecto, e entre elas Maquiavel teria reconhecido grandes filósofos, historiadores e outros homens famosos da Antiguidade e perguntou a eles quem eram e para onde se dirigiam, ao que eles responderam: "Somos os condenados ao inferno". Segundo Ridolfi e Viroli, Maquiavel terminou o relato aos seus amigos dizendo que preferia ir ao inferno discutir política com os grandes homens da Antiguidade do que ser mandado ao paraíso, para morrer de tédio na companhia dos beatos e dos santos. (RIDOLFI, 2003, p. 283; VIROLI, 1998, p. 17 e 95)

${ }^{280}$ Ideia profundamente trágica de enfrentamento com o destino, e se não houver como fugir, suportá-lo com dignidade (a dignidade da queda).

${ }^{281}$ Como notou Ball: “a virtù é para a política o que a virilidade é para o sexo: o conjunto de qualidades que produzem sucesso nestas atividades nas quais o homem másculo, o vir viril, e o príncipe virtuoso estão respectivamente engajados" (BALL, 1984, p. 528). Observação semelhante foi feita por Pocock: "Even Machiavelli's erotics are made the effect of his pursuit of conquest" (POCOCK, 1985, p. 570)
} 
apenas pelo fato de que Roma seria uma república bem ordenada, pois, como mostramos antes, os modelos de Esparta e Veneza também eram considerados por ele como "bem ordenados" e mais duradouros, e, ainda assim, ele preferia o modelo romano. Também nos parece forçada a tese de que Maquiavel preferia a ordenação romana porque veria nela um "populismo feroz", uma prevalência da plebe ${ }^{282}$. É verdade que ele quer dar um papel maior à plebe do que os aristocráticos humanistas cívicos, mas ele não idealiza a plebe. Estas interpretações apoiam-se em partes importantes da obra de Maquiavel, mas elegem uma ou outra parte e a exageram, procedimento que é perfeitamente válido se estamos preocupados em amenizar o pensamento de Maquiavel para torná-lo mais facilmente digerível diante das preferências normativas contemporâneas, mas que não faz justiça plena ao pensamento do florentino, sobretudo, porque esconde embaixo do tapete uma característica central do pensamento do florentino: o seu vitalismo trágico.

Vitalismo que é perceptível na sua teoria dos humores ${ }^{283}$, na sua exposição sobre a necessidade da refundação contínua ${ }^{284}$ e na sua concepção de virtù $^{285}$, como tentamos mostrar antes. Reconhecido esse vitalismo, como fica a questão da liberdade em Maquiavel? Qual é o significado da tensão entre forças sociais opostas proposta como solução para a stasis?

\footnotetext{
${ }^{282}$ Um dos momentos em que Maquiavel mostra o excesso da plebe: "Inspira este comentário o comportamento do povo romano ao criar a instituição dos tribunos para se opor às pretensões da nobreza. Mal esta medida (que respondia a uma necessidade efetiva) foi concedida, o povo recomeçou o combate à nobreza, almejando partilhar suas riquezas e honrarias - os dois bens mais cobiçados" (MAQUIAVEL, 1519b, I, 37, p. 121). Outro texto sobre o excesso da plebe: "Por outro lado, o desejo do povo florentino era injurioso e injusto, por isto a nobreza com maiores forças às suas defesas se preparava, e assim ao sangue e ao exílio dos cidadãos se chegava" (MAQUIAVEL, 1525a, III, 1, p. 143)

${ }^{283}$ Para Parel, a teoria dos humores devia muito ao naturalismo da medicina. Para Baron também: "In the Florence of Lorenzo de' Medici the Neo-Platonistas as well as humanists of the type of Poliziano were all in intercourse with Toscanelli's circle, and the effects are palpable in their work. As to Machiavelli, his dependence on medical and biological ideas was demonstrated by $\mathrm{O}$. Tommasini in his huge monograph thirty years ago. Had scientific pursuits as yet not played a part, side by side with classical and political interests, in the Florentine groups which influenced the growth of Machiavelli's thought, he would hardly have possessed the intellectual tools he needed for his naturalistic analysis of political disintegration and growth" (BARON, 1943, p. 45)

${ }^{284} \mathrm{O}$ organismo político, como qualquer organismo, precisa passar por purgações periódicas e exercício constante (superação de resistência) para permanecer saudável por mais tempo. A acomodação enfraquece o organismo.

${ }^{285}$ Entre outros, Gilbert destacou que o uso do termo virtù por Maquiavel tinha relação com a o uso do termo na ciência médica da época, que sugeria "vitalidade". GILBERT, 1951, pp. 53-55. Hörnquist lembrou a importância da "grandeza de ânimo" no discurso do florentino. A virtù precisa de exercício, a acomodação dilui a virtude, citamos alguns exemplos em que essa ideia aparece em Maquiavel na parte sobre a refundação contínua.
} 
No primeiro capítulo, mostramos que Von Vacano sugeriu que o conceito de vontade de poder de Nietzsche é iluminado pelo conceito de virtù de Maquiavel. Façamos agora o caminho contrário, analisemos o conceito de virtù do florentino à luz da vontade de poder, para tentar iluminar os impasses acerca da concepção de liberdade do florentino. Retomemos o texto já citado de Nietzsche em que ele faz uma referência à virtù:

“O que é bom? - Tudo o que eleva o sentimento de poder, a vontade de poder, o próprio poder no homem.

O que é mau? - Tudo o que vem da fraqueza.

O que é felicidade? - O sentimento de que o poder cresce, de que uma resistência é superada.

Não a satisfação, mas mais poder; sobretudo não a paz, mas a guerra; não a virtude, mas a capacidade (virtude à maneira da Renascença, virtù, virtude isenta de moralina)” (NIETZSCHE, 1888a, aforismo 2, p. 11)

A virtù da Renascença isenta de "moralina", virtù como capacidade de superar resistências é a virtù de Maquiavel. O florentino chegara a esta concepção principalmente por duas vias, uma delas consistiu em uma radicalização do espírito renascentista de pensar os antigos em termos próprios, separados do contexto cristão, e pela ideia de que seria preciso imitar os antigos, e, entre estes, as principais referências eram, para ele, os poetas e historiadores (mais profundamente marcados pelos aspectos "trágicos" da cultura antiga, por exemplo, a ligação entre agonismo e vitalidade) e não tanto os filósofos (em geral críticos do trágico). A outra via foi a sua aproximação com o naturalismo proveniente da "ciência" renascentista, a medicina e a astrologia. Duas vias que o levaram a um rompimento, talvez inédito até ele, com os pressupostos da tradição judaico-cristã.

Como procuramos mostrar no primeiro capítulo, também no contexto intelectual de Nietzsche havia este espírito de pensar os antigos em termos próprios e o projeto de imitá-los, que aparecia já na obra de Winckelman, e, em Nietzsche há uma crítica aos filósofos e uma preferência pelos poetas e historiadores antigos. Neste caminho para a Grécia (e todo retorno ao princípio é um começo novo, “novos modos e ordenações”), Nietzsche parou na Itália de 
Maquiavel, e encontrou no florentino um reforço para o seu filosofar com o martelo contra a tradição judaico-cristã, vista como debilitante. Com o eclipse dos pressupostos dessa tradição, a "morte do fundamento", restou, para Nietzsche, "o mundo visto de dentro", constituído por forças em relação de tensão com outras forças, com hierarquias provisórias de forças que se alteram quando surge um elemento diferencial de força. Nesse mundo, o eterno devir é visto como jogo criativo de forças e a vida entendida como vontade de poder, como ambição ilimitada dos organismos, como pleonexia, que precisa encontrar limitação, resistência, para evitar a autodestruição e para permitir um aumento da força.

Maquiavel pode ser inserido neste ponto de vista trágico que entende a vida como vontade de poder, e esta como perpétua superação de si. Nesta visão, o paradigma da arena é considerado o mais adequado para permitir o desenvolvimento da vida, pois uma cidade saudável, assim como um indivíduo saudável, tem que "ser rico em oposições" para ser fecundo. A fecundidade exige, portanto, a disputa, e esta, ao mesmo tempo, funciona como válvula de escape para a pulsão para o poder e lhe fornece uma medida, na forma das ambições adversárias. Para evitar que a disputa se transforme em disputa funesta, destrutiva, a arena precisa ser organizada de modo a manter uma tensão produtiva sem que nenhuma das partes possa chegar à preponderância absoluta, à tirania, pois ela eliminaria a disputa, fonte de vitalidade. Na disputa, deve haver equilíbrio entre os adversários, o que exige uma certa equidade na arena, uma desigualdade grande como a de Nápoles, segundo Maquiavel, tornaria impossível a liberdade. A desigualdade impediria uma verdadeira disputa - em que medida a classe e a herança não são proteções contra a disputa? -, e a república deve estar aberta ao talento dos cidadãos de todas as classes $^{286}$. Por fim, a disputa precisa ser "embelezada", assim como os instintos precisam ser

\footnotetext{
${ }^{286}$ Segundo Maquiavel, um dos motivos para o sucesso da república romana é que nenhum cidadão era impedido de servir ao país em virtude do seu nascimento em uma classe inferior: "ninguém tinha barrado o caminho a nenhum posto e a nenhuma honraria, e que a virtù era encontrada em qualquer casa onde a pobreza habitasse (MAQUIAVEL, 1519a, III, 25, p. 399). Maurizio Viroli comenta: "Finally, and for Machiavelli this is a consideration of the greatest importance, in a good republic poor citizens have the same chance to attain public honours as anybody else: in Rome 'poverty did not bar you from any office or from any honor, and virtue was
} 
estilizados pela cultura, que cria uma determinada hierarquia entre os instintos, um determinado equilíbrio, uma tensão produtiva entre eles.

Nesse sentido, a liberdade para Maquiavel não se identifica nem com o humor do povo, nem com o dos grandes. Sem a resistência do povo, a pulsão para o poder dos grandes seria destrutiva. O povo, por sua vez, quer a liberdade para não ser dominado, porque ainda não tem o poder, se tivesse quereria a supremacia - como teria ocorrido com a plebe em Florença, segundo Maquiavel -, se não conseguisse a supremacia quereria "justiça", ou "ausência da possibilidade de interferência arbitrária". Sugerimos que, mais do que liberdade como não-dominação, a liberdade maquiaveliana confunde-se com a vitalidade, ela é desenvolvimento expansivo, expansão que é sempre positiva, movida por uma pulsão para o poder, um querer dar forma, influir, participar. A vitalidade expansiva deve ser garantida por uma constituição mista que é uma arena, um equilíbrio tenso entre forças sociais opostas no máximo nível possível antes que a disputa se transforme em disputa funesta. Esta liberdade encontrada pelo trágico Maquiavel é uma liberdade "vista de dentro", é uma gaia liberdade, quer dizer, liberdade como desenvolvimento criativo de potencialidade imanente, não como liberdade abstrata, como polo oposto à necessidade. Nesta concepção, a liberdade negativa é instrumental para a liberdade positiva, já que o continuum entre as duas liberdades é a vitalidade expansiva (positiva), e a arena institucional-legal (que garante a liberdade negativa) é um instrumento que fornece medida para as disputas e canaliza a vitalidade expansiva dos cidadãos para o bem comum e para a grandeza da pátria, evitando a autodestruição que poderia ocorrer por meio da vitalidade expansiva desmedida, perigo que é particularmente intenso nas repúblicas, pois nas "repúblicas há mais vida". ${ }^{287}$

A medida desta vitalidade, para Maquiavel, não é produzida apenas pela arena 
institucional-legal capaz de renovação contínua, mas também, de certa forma, pelo mito, pois Maquiavel não era um homem religioso, entretanto, considerava a religião fundamental para a coesão social. Ele não questionava a verdade ou não da religião, mas a sua utilidade para a virtù e a república. Essa preocupação do florentino devia-se a uma avaliação acerca da insuficiência da arena institucional-legal?

Maquiavel chega a levantar a hipótese de que um Estado com boas leis e ordenações não têm necessidade das "virtudes de um bom homem", o que poderia indicar que a arena institucional-legal seria suficiente para fornecer medida ${ }^{288}$. Nesse sentido, Maquiavel cita algumas vezes a França como exemplo ${ }^{289}$. Sabemos que a monarquia absolutista francesa já contava com o modo estatista de governar, para usar o termo de Araújo, pois possuía impostos permanentes, exército permanente e burocracia, quer dizer, possuía meios concentrados de coerção capazes de dobrar as vontades em caso de necessidade. O Estado assim organizado não era tão vulnerável em relação à stasis. Nessa configuração, a ordem social não depende tanto dos costumes e da virtude. Mas nas cidades-estado, tanto as antigas quanto as da Itália de Maquiavel, ainda não existia o modo estatista de governar. As cidades-estado italianas se organizavam na

\footnotetext{
288 “As cidades, e principalmente as que não estão bem ordenadas, que sob o nome de república se administram, com frequência variam seus governos e estados não da liberdade à servidão, como muitos acreditam, mas da servidão ao desregramento. Porque da liberdade só é celebrado o nome pelos criados [ministri] da permissão, que são o povo, ou pelos da servidão, que são os nobres, desejando, todos estes, não ser pelas leis nem pelos homens submetidos. A verdade é que, mesmo quando acontece (e acontece raramente) que nelas surja um homem sensato, bom e poderoso, do qual venham leis que aquietem esses humores nos nobres e nos cidadãos, ou de tal maneira os limitem que não possam fazer mal, então é quando esta cidade pode-se chamar livre, e este estado pode-se julgar estável e firme: por estar fundado em boas leis e boas ordenações, não tem necessidade das virtudes de um bom homem, com têm outros, que o mantenha". (MAQUIAVEL, 1525a, IV, 1, p. 187) Grifos nossos.

289 “É sobretudo no reino da França que se pode perceber o efeito salutar desta conduta, já que o seu governo, mais do que qualquer outro, está sujeito ao império das leis e das instituições. São os parlamentos, e sobretudo o de Paris, que conservam e controlam o Estado. A constituição do Estado é revigorada toda vez que há uma sentença contra um dos príncipes do reino, ou um julgamento contra o próprio rei. Se a França se pôde manter assim até os nossos dias, isto se deve ao fato de se haver oposto constantemente e com coragem às pretensões da nobreza" (MAQUIAVEL, 1519b, III, 1, p. 304). Grifos nossos. Há outro momento nos Discorsi em que Maquiavel elogia o modelo francês: "Com efeito, só há uma união e felicidade nos Estados sujeitos a um governo único, monárquico ou republicano, como a França e a Espanha (...) Por outro lado, se a Igreja não foi tão forte como para poder ocupar toda a Itália, não permitiu que qualquer outro país dela se apossasse; fez assim com que esta nação não se pudesse reunir sob um só chefe, mantendo-se dividida entre vários príncipes ou senhores. Daí a desunião e a fraqueza, que a reduziram a presa não só de bárbaros ferozes, mas do primeiro que quisesse ataca-la", (MAQUIAVEL, 1519b, I, 12, p. 62) Grifos nossos.
} 
forma república, quer dizer, não havia clara separação entre civitas e Estado, nem um sistema de tributos permanente e capaz de sustentar um exército permanente e uma burocracia profissional. Vimos antes que nas cidades-estado a stasis era constante, e estes conflitos entre os humores da plebe e da nobreza, podiam assumir formas mais ou menos intensas. Mostramos que a decadência das cidades-estado era explicada por antigos e por modernos como resultado da decadência dos costumes. A preservação dos costumes e o discurso das virtudes possuía uma centralidade política que é desconhecida para nós que vivemos há muito tempo no interior do modo estatista de governo. Nesse contexto, Maquiavel não considerava a arena institucionallegal suficiente para fornecer medida, pois, segundo Maquiavel, quando os costumes decaem as leis são impotentes:

"De onde se conclui que, quando a massa do povo é sadia, as desordens e os tumultos não chegam a ser daninhos: mas quando está corrompida, mesmo as leis melhor ordenadas são impotentes - a menos que sejam manipuladas habilmente por uma personalidade vigorosa, respeitada pela sua autoridade, e que possa cortar o mal pela raiz" (MAQUIAVEL, 1519b, I, 17, p. 74).

Ainda sobre a insuficiência das leis frente à corrupção dos costumes, prossegue o florentino:

"Vamos supor, em primeiro lugar, uma cidade que chegou ao estado máximo de corrupção, onde a questão se apresenta com toda a força da sua dificuldade. Onde o desregramento é universal, não há leis nem instituições que o possam reprimir. De fato, os bons costumes só podem ser conservados com o apoio de boas leis, e a observação das leis exige bons costumes. Além disto, as leis e as instituições estabelecidas na origem de uma república, quando os cidadãos eram virtuosos, se tornam insuficientes quando eles começam a se corromper. E se os acontecimentos determinam alterações nas leis, como o mais comum é que as instituições não se modifiquem, a legislação nova fica sem efeito, já que as instituições originais cedo as corrompem” (MAQUIAVEL, 1519b, I, 18, p. 75).

Os bons costumes precisam das boas leis, mas estas também precisam dos bons costumes e as "leis e instituições" feitas na origem, quando os cidadãos ainda tinham virtude, tornam-se 
insuficientes quando o desregramento cresce, e Maquiavel ainda acrescenta uma dimensão trágica, ao comentar que o mais comum é que as instituições não se modifiquem, ainda que os acontecimentos exigissem uma mudança, o que faz com que as novas leis fiquem "sem efeito".

Maquiavel chega a dizer que em situações de grande corrupção é preferível uma monarquia ${ }^{290}$. Para Maquiavel, o bem público ainda depende do homem de bem, pois a arena institucional-legal seria insuficiente frente a um grau elevado de corrupção. A virtude não é dispensável em uma república. Para o florentino, é necessário adicionar espírito a esta máquina que é a arena institucional-legal. É requerida uma boa nova capaz de fazer com que os cidadãos desejem a virtude, tenham coragem e respeitem as leis e instituições:

“Quando se examina a história romana, é forçoso reconhecer que a religião servia para comandar os exércitos, levar a concórdia ao povo, zelar pela segurança dos justos e fazer com que os maus corassem pelas suas infâmias (...) De fato, nunca nenhum legislador outorgou a seu povo leis de caráter extraordinário sem apelar para a divindade, pois sem isto não seriam aceitas” (MAQUIAVEL, 1519b, I, 11, p. 58)

Para Maquiavel, Numa foi mais importante que seu antecessor Rômulo, fundador de Roma, pois Numa fundou a religião romana, o que permitiu que um povo bravio experimentasse a paz e visse surgir em seu seio grandes homens. Segundo Maquiavel, Numa havia percebido que a religião é o "agente mais poderoso para a manutenção da sociedade"291. As críticas de Maquiavel à Igreja Católica não estavam relacionadas à sua descrença, mas aos efeitos políticos nocivos que ele via nas ações da Igreja, considerada por ele como responsável pelo fato dos italianos viverem sem religião e sem moral e responsável pela divisão da Itália:

"Se a religião se tivesse podido manter na república cristã tal como o seu divino fundador a estabelecera, os

\footnotetext{
290 "Pois as instituições apropriadas a um povo corrompido são diferentes das que se ajustam ao que não o é; não convém a mesma forma a matérias inteiramente diversas (...) Do que acabo de dizer, transparece a dificuldade, ou mesmo a impossibilidade, de manter-se o governo republicano numa cidade corrompida, ou de ali estabelecê-lo. De qualquer maneira, mais vale a monarquia do que o estado popular para assegurar que os indivíduos cuja insolência as leis não podem reprimir sejam subjugados por uma autoridade real”. (MAQUIAVEL, 1519b, I, 18, p. 77)

291 "O novo monarca encontrou um povo bravio; quis impor-lhe os jugo da obediência civil, fazendo com que experimentasse as artes da paz. Voltou o seu olhar para a religião como agente mais poderoso da manutenção da sociedade, fundando-a sobre tais bases que nenhuma outra república demonstrou jamais maior respeito pelos deuses, o que facilitou todos os empreendimentos do Senado e dos grandes homens que aquele Estado viu nascer". (MAQUIAVEL, 1519b, I, 11, p. 57)
} 
Estados que a professavam teriam sido bem mais felizes. Contudo, a religião decaiu muito. Temos a prova mais marcante desta decadência no fato de que os povos mais próximos da Igreja Romana, a capital da nossa religião, são justamente os menos religiosos (...) É, portanto, à Igreja e aos sacerdotes que os italianos devem estar vivendo sem religião e sem moral (...) Por outro lado, se a Igreja não foi tão forte como para poder ocupar toda a Itália, não permitiu que qualquer outro país dela se apossasse; fez assim com que esta nação não se pudesse reunir sob um só chefe, mantendo-se dividida entre vários príncipes ou senhores. Daí a desunião e a fraqueza, que a reduziram a presa não só de bárbaros ferozes, mas do primeiro que quisesse ataca-la"”" (MAQUIAVEL, 1519b, I, 12, p. 62)

Maquiavel levanta a possibilidade de que se a religião tivesse se mantido como o seu "divino fundador a estabelecera" os estados que a professavam teriam sido mais felizes, entretanto, a religião “decaiu muito". Avaliação que separa o fundador dos desenvolvimentos posteriores, deixando margem para uma possibilidade de renovação do cristianismo. A preocupação de Maquiavel é com os efeitos cívicos da religião, e, nesse sentido, o florentino demonstrou preferência pela religião pagã porque fortaleceria os homens e estimularia o civismo, enquanto a religião cristã era vista por ele como enfraquecedora, como vimos em uma parte já citada dos Discorsi ${ }^{292}$. Entretanto, Maquiavel parece considerar mais difícil uma conversão ao paganismo, pois comenta que é mais fácil converter quem ainda não têm religião, como os "rudes habitantes das montanhas", mais preparados para receber "novas impressões" e "menos corrompidos":

“Admirador das virtudes e da sabedoria de Numa, o povo romano se empenhou em obedecer às instituições que ele formulou. É verdade que o domínio exercido naquela época pela religião, e a simploriedade dos homens que Numa devia governar, facilitaram-lhe o cumprimento dos seus desígnios, de tal modo os espíritos estavam preparados para receber novas impressões. Está também fora de dúvida que o legislador que hoje quisesse fundar

292 "Quando se considera por que os povos da antiguidade amavam a liberdade mais do que os da nossa época, parece-me que a razão é a mesma que explica por que hoje os homens são menos robustos - o que se relaciona, a meu juízo, com a diferença entre a nossa educação e a dos antigos, e a diferença, igualmente grande entre a nossa religião e a dos antigos (...) nossa religião, mostrando a verdade e o caminho único para a salvação, diminuiu o valor das honras deste mundo. Os pagãos, pelo contrário, que perseguiam a glória (considerada o bem supremo), empenhavam-se com dedicação em tudo que lhes permitisse alcançá-la (...) Nossa religião, ao contrário, só santifica os humildes, os homens inclinados à contemplação, e não à vida ativa. Já os pagãos davam a máxima importância à grandeza d'alma, ao vigor do corpo, a tudo, enfim, que contribuísse para tornar os homens robustos e corajosos. Se a nossa religião nos recomenda hoje que sejamos fortes, é para resistir aos males, e não para incitar-nos a grandes empreendimentos" (MAQUIAVEL, 1519b, II, 2, p. 199). 
um Estado encontraria menos obstáculos entre os rudes habitantes das montanhas, onde a civilização ainda é desconhecida, do que entre os habitantes das cidades, cujos costumes já estão corrompidos. Da mesma forma, um escultor fará mais facilmente uma bela estátua com um bloco informe do que com um mármore já trabalhado por mão imperita.”. (MAQUIAVEL, 1519b, I, 11, p. 58)

O fundador de religiões é comparado a um escultor, um artista que promove uma estilização das vontades de um modo favorável ao bem comum, e Maquiavel demonstra preferência por uma religião que não seja debilitante, que fortaleça os homens, aprove a busca de glória mundana e estimule o respeito à arena institucional-legal. A arena e a bela ilusão formando uma república em que a vitalidade expansiva dos cidadãos colabora para a vitalidade expansiva da república, permitindo o surgimento de grandes homens e grandes empreendimentos, entretanto, mesmo esta república cairá a seu tempo, o que levaria à pergunta: valeu à pena? E o Maquiavel trágico responderia: mas é claro! Todas as coisas deste mundo estão em movimento, foi um belo espetáculo com muitos exemplos de virtude, façamos agora um bom carnaval e comecemos os preparativos para a apresentação da nossa nova comédia. 


\section{REFERÊNCIAS BIBLIOGRÁFICAS:}

ADORNO, Theodor W. \& HORKHEIMER, Max. Dialética do Esclarecimento. Rio de Janeiro: Ed. Jorge Zahar, 1985.

ADKINS, Arthur W.H. (1960). Merit and Responsibility. A Study in Greek Values. Chicago: University of Chicago Press, 1975.

ADVERSE, Helton. Maquiavel: Política e Retórica. Ed. UFMG, 2009.

AGUILA, Rafael del. (2001) Machiavelli's Theory of Political Action: Tragedy, Irony and Choice. EUI Working Paper SPS No. 2001/3. European University Institute, Florence. Department of Political and Social Sciences.

ALLIEZ, Éric. Gilles Deleuze: uma vida filosófica. Ed. 34, 2000.

ANDREWES, A. “The Greek Tyrants". Londres: Hutchinson's University Library, 1957.

ANSELL-PEARSON, Keith. Nietzsche contra Rousseau: Nietzsche moral and political thought. Cambridge University Press, 1991.

. Nietzsche como pensador político. Rio de Janeiro: Ed. Jorge Zahar, 1997.

APPLEBY, Joyce / BALL, Terence (eds). Thomas Jefferson: political writings. Cambridge University Press, 1999.

ARANOVITCH, História e Política em Maquiavel. Ed. Discurso Editorial, 2007.

ARAÚJO, Cicero. Quod Omnes Tangit: fundações da república e do Estado. Tese de Livre Docência, FFLCH-USP, 2004.

ARENDT, Hannah. A Condição Humana. Rio de Janeiro 10ª edição. Ed. Forense Universitária, 2001. O que é política? Ed. Bertrand Brasil, 2007.

ARISTÓFANES. As Nuvens; Só para mulheres; Um deus chamado dinheiro. $2^{\mathrm{a} e d . ~ R i o ~ d e ~ J a n e i r o: ~ E d . ~ J o r g e ~ Z a h a r, ~}$ 2000.

ARISTÓTELES. Poética. Em: A Poética Clássica (trad. Jaime Bruna). Ed. Cultrix, 2005. . Ética a Nicômacos. Ed. Unb, 1985. . A Política. Ed. Unb, 1985.

AUBENQUE, P. A Prudência em Aristóteles. Ed. Discurso Editorial, 2003.

BALL, Terence. The Picaresque Prince: Reflections on Machiavelli and Moral Change. In: Political Theory, Vol 12, No 4 (Nov., 1984).

BARON, Hans. Towards a More Positive Evaluation of the Fifteenth-Century Renaissance. In: Journal of the History of Ideas, Vol. 4, № 1 (jan, 1943).

(1953) A Struggle for Liberty in the Renaissance: Florence, Venice, and Milan in the Early Quattrocento. In: The American Historical Review, Vol. 58, No. 2 (Jan., 1953), pp. 265-289.

(1960) The Social Background of Political Liberty in the Early Italian Renaissance. In: Comparative Studies in Society and History, Vol. 2, No. 4 (Jul., 1960), pp. 440-451.

. (1961) Machiavelli: The Republican Citizen and the Author of 'the Prince'. In: The English Historical Review, Vol. 76, No. 299 (Apr., 1961), pp. 217-253. 
(1966) Crisis of the Early Italian Renaissance. Princeton University Press, 1966.

BARTLETT, R.C. The "Realism" of Classical Political Science. American Journal of Political Science, Vol. 38, No. 2, (May, 1994).

BERLIN. Isaiah. (2002) A originalidade de Maquiavel. Em: Estudos sobre a humanidade: uma antologia de ensaios. Ed. Cia das Letras, 2002. pp. 299-348.

. (2002a) Dois Conceitos de Liberdade. Em: Estudos sobre a humanidade: uma antologia de ensaios. Ed.

Cia das Letras, 2002, pp. 226-298.

BIGNOTTO, Newton. Maquiavel Republicano. São Paulo: Ed. Loyola, 1991.

BOCK, Gisela. Civil Discord in Machiavelli’s 'Istorie Fiorentine'. In: Machiavelli and Republicanism. Cambridge University Press, 1990.

BROWN, Alison. The Language of Empire. In: Florentine Tuscany: structures and practices of power (ed. by William Connel and Andrea Zorzi). Cambridge University Press, 2000.

BURCKHARDT, Jacob (1855). The Civilization of the Renaissance in Italy. Penguin Classics, 1990.

CASSIRER, E. The Individual and the Cosmos. Oxford, 1963.

CASTORIADIS, Cornelius. As encruzilhadas do labirinto V. II. Ed. Civilização Brasileira, 2002. . (2004) A descoberta do abismo. Publicado em: Le Monde, 24/ 1/2004.

. (2006) Lo que hace a Grecia 1: de Homero a Heráclito. Seminários 1982-1983. Ed. Fondo de Cultura Económica, 2006.

CHABOD, Federico. Machiavelli and the Renaissance. New York, 1965.

CONNEL, William J. The republican idea. In: Renaissance Civic Humanism: reppraisals and reflections. Cambridge University Press, 2000. Org. Hankins, James. Cambridge University Press, 2000, pp. 14-29.

CONNOLY, W. Speed, Concentric Cultures, and Cosmopolitanism. In: Political Theory, Vol. 28, No. 5 (Oct., 2000), pp. 596-618.

COULANGES, F. A cidade antiga. Ed. Martins Fontes, 2004.

DELEUZE, G. Nietzsche e a filosofia. Portugal, Porto: Ed. Res, 2001.

DIENSTAG, Joshua Foa. Tragedy, Pessimism, Nietzsche. In: Rethinking Tragedy (ed. by Rita Felski). John Hopkins University Press, 2008.

DODDS, E.R. (1951) The Greeks and the Irrational. Boston: Beacon Press, 1957.

DUBOIS, Page. Toppling the Hero. In: In: Rethinking Tragedy (ed. by Rita Felski). John Hopkins University Press, 2008 .

EAGLETON, Terry (2003). Sweet Violence. The Idea of the Tragic. Blackwell Publishing, 2008.

EPSTEIN, S. R. Town and Country: Economy and Institutions in Late Medieval Italy. In: The Economic History Review, New Series, Vol. 46, No 3, (Aug., 1993), pp. 453-477.

. The Rise and Fall of Italian City-States. In: A Comparative Study of Thirty City-State Cultures. Historiskfilosofiske Skrifter 21. Det Kongelige Danske Videnskabernes Selskab. Comission Agent: C.A. Reitzels Forlag. 
Copenhagen, 2000. pp. 277-293.

FINKELBERG, M. Patterns of Human Error in Homer. In: The Journal of Hellenic Studies, Vol. 115 (1995), pp. 15-28.

FINLEY, Moses (1954). El mundo de Odiseo. México: Fondo de Cultura Económica, 1996. Between Slavery and Freedom. In: Comparative Studies in Society and History, Vol. 6, No. 3 (Apr., 1964). (1983). A Politica no Mundo Antigo. Ed. Edições 70, 1983. (1986) A Economia Antiga. Ed. Edições Afrontamento, 1986.

FORDE, S. Varieties of Realism: Thucydides and Machiavelli. In: The Journal of Politics, Vol. 54, No. 2 (May, 1992).

GAMBINO, Giacomo. Nietzsche and the Greeks: Identity, Politics, and Tragedy. In: Polity, Vol. 28, No. 4 (Summer, 1996).

GARIN, E. Italian Humanism. Oxford, 1965.

GILBERT, F. (1951) On Machiavelli's Idea of Virtu. In: Renaissance News, Vol. 4, No. 4 (Winter, 1951). (1965) Machiavelli and Guicciardini : Politics and History in Sixteenth-Century Florence. Princeton; New Jersey: University Press, 1965.

GLOTZ, Gustave. (1928). A Cidade Grega. São Paulo, SP: Difel, 1980.

GOLDHILL, S. Generalizing About Tragedy. In: Rethinking Tragedy. Ed. John Hopkins University Press, 2008

GUARINI, E. F. Machiavelli and the crisis of the Italian Republics. In: Machiavelli and Republicanism. Cambridge University Press, 1990.

GUICCIARDINI, F. Storie fiorentine. Bari : Laterza, 1931.

Opere. Milano: Rizzoli, 1945.

GUNNEL, John G. Interpretation and the History of Political Theory: Apology and Epistemology. In: The American Political Science Review, Vol. 76, No. 2. (Jun., 1982), pp. 317-327.

HABERMAS, Jürgen. O discurso filosófico da modernidade: doze lições. Tradução de Luiz Reppa e Rodnei Nascimento. São Paulo: Martins Fontes, 2002.

HALL, Edith. The Sociology of Athenian Tragedy. In: The Cambridge Companion to Greek Tragedy. Cambridge University Press, 1997.

HANSEN, M. H (Ed.). (1998) Polis and City-State: An Ancient Concept and its Modern Equivalent. Symposium, January 9, 1998. Det Kongelige Danske Videnskabernes Selskab. Comission Agent: C.A. Reitzels Forlag. Copenhagen, 1998.

. (1999) The Athenian Democracy in the Age of Demosthenes. University of Oklahoma Press, 1999. . (2000) A Comparative Study of Thirty City-State Cultures. Historisk-filosofiske Skrifter 21. Det Kongelige Danske Videnskabernes Selskab. Comission Agent: C.A. Reitzels Forlag. Copenhagen, 2000. (2006) Polis: An Introduction to the Ancient Greek City-State. Oxford University Press, 2006. 
HANKINS, James. The “Baron's Thesis” after Forty Years and some recent Studies of Leonardo Bruni. In: ournal of the History of Ideas, Vol. 56, No. 2 (Apr., 1995), pp. 309-338.

(ed.) Renaissance Civic Humanism: reappraisals and reflections. Cambridge University Press, 2000. Cambridge University Press, 2000.

HARTOG, François. Memória de Ulisses: narrativas sobre a fronteira na Grécia Antiga. Ed. Humanitas/UFMG, 2004.

HEGEL, G.W.F. Philosophy of Right. Trad. Knox, T.M.. Oxford: Clarendon, 1942.

Filosofia da História. Brasília: Ed. Unb, 1999.

“"Linhas Fundamentais da Filosofia do Direito ou Direito Natural e Ciência do Estado em Compêndio".

Terceira Parte: A Eticidade. Segunda Seção: A Sociedade Civil. Tradução: Marcos Lutz Müller. Textos Didáticos. Ed. Unicamp, 2000.

Fenomenologia do Espírito. Petrópolis/RJ: Ed. Vozes, 2002.

HESÍODO. Teogonia: a origem dos deuses. Ed. Iluminuras, 1995. Os trabalhos e os dias. Ed. Iluminuras, 1996.

HIRSCHMANN, Albert (1977). As Paixões e os Interesses. Rio de Janeiro: Ed. Record, 2002.

HULLIUNG, Mark. Citizen Machiavelli. Princeton: Princeton University Press, 1983.

JAEGER, W. Paidéia: a formação do homem grego. Ed Martins Fontes, 1995. . Aristóteles. Ed. Fondo de Cultura Económica, 1995.

KAUFMANN, Walter (1968). Philosophy and Tragedy. Ed. Princeton University Press, 1992.

KERFERD, G.B. O movimento sofista. Edições Loyola, 2003.

KOYRÉ, Alexandre. Estudos de História do Pensamento Científico. Ed. Forense Universitária, 1991.

KOSELLECK, Reinhart. Crítica e Crise: uma contribuição à patogênese do mundo burguês. Rio de Janeiro: Eduerj e Ed. Contraponto, 1999.

KYMLICKA, Will. Filosofia Política Contemporânea. Ed. Martins Fontes, 2006.

LAMPERT, Laurence. (1986) Nietzsche Teaching. New Haven: Yale University Press, 1986. . (1997) Leo Strauss and Nietzsche. University of Chicago Press, 1997.

(2005) Nietzsche's Challenge to Philosophy in the Thought of Leo Strauss. In: The Review of Metaphysics, Vol. 58, No. 3 (Mar., 2005).

LEFORT, Claude. Le travail de l'oeuvre Maquiavel. Paris: Gallimard, 1972.

LESKY, Albin. A Tragédia Grega. Ed. Perspectiva, 2006

LONG, A.A. Morals and Values in Homer. In: The Journal of Hellenic Studies, Vol. 90 (1970), pp. 121-139.

LYOTARD, J.F. Lessons in paganism. In: Andrew Benjamin (Ed.), The lyotard reader. Oxford: Blackwell Publishers, 1989.

MACHADO, Roberto. O Nascimento do Trágico: de Schiller a Nietzsche. Rio de Janeiro: Ed. Jorge Zahar, 2006. 
MACINTYRE, Alasdair. Depois da Virtude: um estudo em teoria moral. Ed. Edusc, 2001.

MAFFESOLI, M. The Return of the Tragic in Postmodern Societies. In: Rethinking Tragedy. Ed. John Hopkins University Press, 2008, pp. 319-336.

Time of the Tribes: the decline of individualism in mass society. London: Sage, 1996.

MANIN, B. The Principles of Representative Government. Cambridge University Press, 1997.

MANSFIELD, Harvey C. Machiavelli's Virtue. University of Chicago Press, 1998.

MAQUIAVEL, Nicolau. (1989) Machiavelli Chief Works V. II (ed. Gilbert). Duke University Press, 1989.

(1510) Ritracto di cose di Francia. In: Niccolò Machiavelli - Opere - volume I", a cura di Corrado Vivanti, Einaudi-Gallimard, Biblioteca della Pleiade, Torino, 1997.

. (1513) O Príncipe (Ed.Bilingüe). Ed. Hedra, 2007.

. (1517) L'Asino. In: Tutte le opere storiche e letterarie di Niccolo Machiavelli. Barbera Editore, Firenze, 1929.

. (1518) A Mandragora. Tradução de Mário da Silva. São Paulo: Peixoto Neto (Os grandes dramaturgos),

2004.

. (1519) Discorsi sopra la prima deca di Tito Livio. In: Tutte le opere storiche e letterarie di Niccolo Machiavelli. Barbera Editore, Firenze, 1929.

. (1519a) Discursos sobre a Primeira Década de Tito Lívio. Ed. Martins Fontes, 2007.

(1519b) Discursos sobre a Primeira Década de Tito Lívio. Ed. Unb, 2008.

(1520) A Arte da Guerra. Ed. Martins Fontes, 2006.

(1520a) Vita di Castruccio Castracani. In: Tutte le opere storiche e letterarie di Niccolo Machiavelli. Barbera Editore, Firenze, 1929.

(1520b) A Vida de Castruccio Castracani da Lucca. Porto Editora, 2003.

. (1521) Discursum Florentinarum Rerum. In: Niccolò Machiavelli: Tutte le Opere. Sansoni editore, 1971.

(1525) Istorie Fiorentine.In: Opere di Niccolò Machiavelli v.2. Torino: Unione tipografico-editrice torinese, 1986.

(1525a) História de Florença. Ed. Musa editorial, 1995.

(1527) Clizia. In: Collezione di Teatro 216, collana diretta da Paolo Grassi e Gerardo Guerrieri, Giulio Einaudi editore, 1977.

MARX, Karl. “Cartas Cruzadas en 1843”. In: Obras Fundamentales I. Marx: Escritos de Juventud. México: Fondo de Cultura Económica, 1987.

. Formações econômicas pré-capitalistas. Ed. Paz e Terra, 1991.

. A Ideologia Alemã. Ed. Hucitec, 1996.

A Sagrada Família. Trad. Marcelo Backes. Ed. Boitempo, 2003.

MCCORMICK, John P. (1993). Addressing the Political Exception: Machiavelli's "Accidents" and the Mixed Regime. In: The American Political Science Review, Vol. 87, No. 4, (Dec., 1993), pp. 888-900. 
. (1994) Fear, Technology, and the State: Carl Schmitt, Leo Strauss, and the Revival of Hobbes in Weimar and National Socialist Germany. In: Political Theory, Vol. 22, No. 4, (Nov., 1994), pp. 619-652.

. (1997) Carl Schmitt's critique of liberalism: against politics as technology. Cambridge University Press, 1997.

(2001) Machiavellian Democracy: Controlling Elites with Ferocious Populism. In: The American Political Science Review, Vol. 95, No 2, (Jun., 2001), pp. 297-313.

. (2003) Machiavelli against Republicanism: On the Cambridge School's “Guicciardini Moments”. In: Political Theory, Vol. 31, No 5, (Oct., 2003), pp. 615-643.

(2006) Contain the wealthy and patrol the magistrates: restoring elite accountability to popular government. In: American Political Science Review, vol. 100, no. 2, 2006.

(2007) Machiavelli's Political Trials and "The Free Way of Life". In: Political Theory 2007; 35; 385.

MOMIGLIANO, A. As raízes clássicas da historiografia moderna. Ed. Edusc, 2004.

MOSSÉ, Claude. Péricles: o inventor da democracia. Ed. Estação Liberdade, 2008.

MOUFFE, Chantal. Por um modelo agonístico de democracia. Em: Rev. Sociologia e Política. Curitiba, 25, p. 165177, jun. 2006.

MOURA, Carlos A. R. de. Nietzsche: Civilização e Cultura. Ed. Martins Fontes, 2005.

MUMFORD, Lewis. (1961) A cidade na história: suas origens, transformações e perspectivas. Ed. Martins Fontes, 1991.

MURRAY, Oswyn. Cities of Reason. In: The Greek City from Homer to Alexander. Oxford: Oxford University Press, 1990.

NAJEMY, John. (1979) Guild Republicanism in Trecento Florence: The Sucesses and Ultimate Failure of Corporate Politics. In: The American Historical Review, Vol. 84, No 1, (Feb., 1979), pp. 53-71.

(1982) Corporatism and Consensus in Florentine Electoral Politics, 1280-1400. University of North Carolina, 1982.

(1996) Baron's Machiavelli and Renaissance Republicanism. In: The American Historical Review, Vol. 101, No 1, (Feb., 1996), pp. 119-129.

. (2000) Civic Humanism and Florentine Politics. In: Renaissance Civic Humanism: reppraisals and reflections. Cambridge University Press, 2000. Org. Hankins, James. Cambridge University Press, 2000.

(2002) Politics: Class and Patronage in Twentieth-Century Italian Renaissance Historiography. In: The Italian Renaissance in the Twentieth Century. Ed. A. Grieco, M. Rocke, and F. Gioffredi Superbi (Florence: Leo A. Olschki and Villa I Tatti, The Harvard University Center for Italian Renaissance Studies, 2002), pp. 119-36. . (2004) Italy in the Age of the Renaissance. 1300-1550. Oxford University Press, 2004.

NEWELL, W.R. (1987) How Original is Machiavelli?: A Consideration of Skinner's Interpretation of Virtue and Fortune. In: Political Theory, Vol. 15, No. 4 (Nov., 1987).

(1988) Machiavelli and Xenophon on Princely Rule: A Double-Edged Encounter. In: The Journal of Politics, Vol. 50, No. 1 (Feb., 1988). 
NIETZSCHE, F. (1870) Introdução à tragédia de Sófocles. Rio de Janeiro: Ed. Jorge Zahar, 2006.

. (1872) O Nascimento da Tragédia ou Helenismo e Pessimismo. São Paulo: Ed. Companhia das Letras, 1992.

(1872a) Cinco prefácios para cinco livros não escritos. Ed. 7 Letras, 2005.

(1874) On the Uses and Disadvantages of History for Life. In: Friedrich Nietzsche, Untimely Meditations, trans. R. J. Hollingdale. Cambridge: Cambridge University Press, 1983.

(1878) Humano, Demasiado Humano. São Paulo: Ed. Companhia das Letras, 2005.

. (1881) Aurora. São Paulo: Ed. Companhia das Letras, 2004.

(1882) Gaia Ciência. São Paulo: Ed. Cia das Letras, 2005.

. (1884) Assim Falou Zaratustra. Petrópolis, RJ: Ed Vozes, 2007.

. (1886) Além do Bem e do Mal: prelúdio a uma filosofia do futuro. São Paulo: Ed. Companhia das Letras, 2005.

. (1887) Genealogia da Moral. São Paulo: Ed. Cia das Letras, 2004.

(1888) O Crepúsculo dos Ídolos. Rio de Janeiro: Relumé Dumará, 2000.

. (1888a) O Anticristo e Ditirambos de Dionísio. Ed. Companhia das Letras, 2007.

. (1906) A Vontade de Poder. Rio de Janeiro: Ed. Contraponto, 2008.

. (1908) Ecce Homo. São Paulo: Ed. Cia das Letras, 2008.

NUSSBAUM, M.C. The Therapy of Desire: Theory and Practice in Hellenistic Ethics. Princeton University Press, 1994.

The Morality of Pity. In: Rethinking Tragedy (ed. by Rita Felski). John Hopkins University Press, 2008.

OBER, Joshiah. The Athenian Revolution. New Jersey: Princeton University Press, 1996. $2^{\mathrm{a}}$ edição, 1999.

Political dissent in the democrathic Athens: intelectual critics of popular rule. New Jersey: Princeton University Press, 1998. $3^{\text {a }}$ edição, 2002.

OSBORNE, R. The Demos and its Divisions in Classical Athens. In: The Greek City from Homer to Alexander (edited by Oswyn Murray and Simon Price). Ed. Clarendon Prees, Oxford, 1991.

PAINE, Thomas. The Rights of Man (1792). In: Political Writings, ed. Bruce Kuklick, 49-203. Cambridge: Cambridge University Press, 1989.

PALMEIRA, Miguel Soares. Moses Finley e a "economia antiga": a produção social de uma inovação historiográfica. Tese de doutorado em História Social, defendida na FFLCH-USP em 2007.

PALMER, M. Machiavellian virtù and Thucydidean aretē: Traditional Virtue and Political Wisdom in Thucydides. The Review of Politics, Vol. 51, No. 3 (Summer, 1989), pp. 365-385.

PANOFSKY, Erwin. (1960) Renaissance and Renascences in Western Art. New York: Harper \& Row, 1972.

PAREL, A. The Machiavellian Cosmos. Ed. Yale University Press, 1992.

PINKER, Steven. Tábula Rasa: a negação contemporânea da natureza humana. Ed. Cia das Letras, 2004.

PLATÃO. A República. Ed. Martins Fontes, 2006. 
Protágoras. Ed. EDUFPA, 2002.

PLUTARCO. Vida de Sólon. (Tradução nossa). Em: Plutarch. Ed. Britannica Great Books, No¹4, 1952.

POCOCK, J.G.A. The Machiavellian Moment. New Jersey: Princeton University Press, 1975.

(1985) Machiavelli in the Liberal Cosmos. In: Political Theory, Vol. 13, No. 4 (Nov., 1985), pp. 559-574.

. Linguagens do Ideário Político. Tradução Fabio Fernandez. São Paulo: Edusp, 2003.

PURCELL, N. e HORDEN, P. The Corrupting Sea: a study of mediterranean history. Ed. Blacwell, 2000.

RAHE, Paul A. (1994) Republics Ancient and Modern. The Ancien Régime in Classical Greece. Ed. University of North Carolina Press, 1994.

(1995) Thomas Jefferson's Machiavellian Political Science. The Review of Politics, Vol. 57, No. 3 (Summer, 1995).

RICHTER, Melvin. "Reconstructing the History of Political Languages: Pocock, Skinner, and the Geschichtliche Grundbegriffe". History and Theory, Vol. 29, No. 1. 1990, pp. 38-70.

RIDOLFI, Roberto. Biografia de Nicolau Maquiavel. São Paulo: Ed. Musa, 2003.

RINESI, Eduardo (2002). Política e Tragédia: Hamlet, entre Maquiavel e Hobbes. Tese de doutorado defendida em maio de 2002, na FFLCH-USP, com orientação do prof. Renato Janine Ribeiro.

ROMILLY, Jacqueline de (1970). A tragédia grega. Ed. Edições 70, 2008.

ROSSI, Miguel Angel. A filosofia política diante do primado do sujeito e da pura fragmentação. Em: Filosofia Política Contemporãnea: Controvérsias sobre Civilização, Império e Cidadania. Atilio Boron, 1a ed. - Buenos Aires: Consejo Latinoamericano de Ciencias Sociales - CLACSO; São Paulo: Departamento de Ciência Política. Faculdade de Filosofia, Letras e Ciências Humanas. Universidade de São Paulo, 2006.

Schmitt y la esencia del catolicismo. Em: Carl Schmitt, su época y su pensamiento, EUDEBA; Buenos Aires, 2002.

SANDEL, Michael. "The procedural republic and the unencumbered self". In: "Communitarianism and Individualism". Org. Avineri, Shlomo \& Avner De-Shalit. Oxford University Press. 1992.

SASSO, G. Studi su Machiavelli. Napole, 1967.

SCHOPENHAUER, Arthur. O mundo como vontade e representação. Rio de Janeiro: Ed. Contraponto, 2001.

SILVA, Ricardo. Maquiavel e o conceito de liberdade em três vertentes do novo republicanismo. In: Revista Brasileira de Ciências Sociais, Vol. 25, nº 72, fevereiro, 2010.

SKINNER, Quentin (1981). Maquiavel. Ed. Brasiliense, 1988.

(1989) The State. In: Political Innovation and Conceptual Change. Cambridge: Cambridge University Press, 1989.

(1990) Machiavelli's Discorsi and the Prehumanist Origin of Republican Ideas. In: G.Bock, Q. Skinner and M. Viroli (eds): Machiavelli and Republicanism, Cambridge Mass: Cambridge University Press, 1990, pp. 121141.

(1990a) The Republican Ideal of Political Liberty. In: Machiavelli and Republicanism. Cambridge: 
Cambridge University Press, 1990, pp, 293-309.

(1996) As Fundações do Pensamento Político Moderno. São Paulo, SP: Companhia das Letras, 1996.

(1999) Liberdade antes do Liberalismo. São Paulo, SP: Unesp, 1999.

SMITH, Steven B. Leo Strauss: Between Athens and Jerusalem. In: The Review of Politics, Vol. 53, No. 1, Special Issue on the Thought of Leo Strauss (Winter, 1991), pp. 75-99.

SÓFOCLES. Antígona. Em: Trilogia Tebana. Ed. Jorge Zahar. Ájax (Tradução de Trajano Vieira). Em: Três tragédias gregas. Ed. Perspectiva, 1997.

SOURVINOU-INWODD, Christiane. What is Polis Religion? In: The Greek City from Homer to Alexander (edited by Oswyn Murray and Simon Price). Ed. Clarendon Prees, Oxford, 1991.

SPINOZA, B. Ética (ed. Bilíngue). Ed. Autêntica, 2008.

STE CROIX, G.E.M de. The Class Struggle in the Ancient Greek World: from the Archaic Age to the Arab Conquests. Ed. Duckworth, 1981.

STEINER, George (1961). A morte da tragédia. Ed. Perspectiva, 2006.

(2008) Tragedy”, Reconsidered. In: Rethinking Tragedy (ed. by Rita Felski). John Hopkins University Press, 2008, p. 30.

STRAUSS, Leo. (1952) Persecution and the Art of Writing. Glencoe, 111.: The Free Press, 1952. (1954) On a Forgotten Kind of Writing. In: Chicago Review, Vol. 8, No. 1 (1954), pp. 64-75. (1957) What is Political Philosophy? In: The Journal of Politics, Vol. 19, No. 3, (Aug., 1957) (1958). Thoughts on Machiavelli. University of Chicago Press, 1978. (1964) The City and Man. University of Chicago Press, 1964.

. (1967) Jerusalem and Athens: Some Introductory Reflections. In: Studies in Platonic Political Philosophy, ed. Thomas Pangle (Chicago: University of Chicago Press, 1983), pp. 147-73.

(1981) Progress or Return? The Contemporary Crisis in Western Civilization. In: Modern Judaism, Vol. 1, No. 1 (May, 1981).

(1983) Note on the Plan of Nietzsche's Beyond Good and Evil. In: Leo Strauss, Studies in Platonic Political Philosophy. Chicago: University of Chicago Press, 1983.

. (1995) Philosophy and Law. Trans. Eve Adler. Albany: State University of New York Press, 1995.

SZONDI, Peter. (1961) Ensaio sobre o trágico. Rio de Janeiro: Ed. Jorge Zahar, 2004.

TANDY, David W. Warriors and Traders: The Power of Market in Early Greece. University of California Press, 1997.

TARROW, S. From Comparative Historical Analysis to "Local Theory": The Italian City-State Route to the Modern State. Theory and Society, Vol. 33, No. 3/4, Special Issue: Current Routes to the Study of Contentious Politics and Social Change, (Jun. - Aug., 2004), pp. 443-471.

THEOGNIS. Fragment I. 1135. Em: Greek Elegiac Poetry: from the Seventh to the Fifth Centuries BC. Editado e traduzido por Douglas E. Gerber. Loeb Classical Library, Harvard, 1999. 
TILLY, Charles. Cities and States in Europe, 1000-1800. In: Theory and Society, Vol. 18, No 5, Special Issue on Cities and States in Europe, 1000-1800, (Sep., 1989), pp. 563-584.

Coerção, Capital e Estados Europeus. Ed. Edusp, 1996.

TUCÍDIDES. História da Guerra do Peloponeso. Ed. UNB, 1999.

URBINATI, N. Representative Democracy: principles and genealogy. The University of Chicago Press, 2006.

WALLACE, Jennifer. The Cambridge Introduction to Tragedy. Cambridge University Press, 2007.

WALKER, William. Sallust and Skinner on civil liberty. In: European Journal of Political Theory, 5 (3): 237-259, 2006.

WEBER, Max. Economia y Sociedad. Ed. Fondo de Cultura Económica, 1992.

. Ciência e Política: duas vocações. Ed. Cultrix, 1997.

WILLIAMS, Raymond (2001). Modern Tragedy. Broadview encore editions, 2006.

WOOD, Ellen Meiksins. Democracia Contra o Capitalismo - A renovação do materialismo histórico. Ed. Boitempo, 2003.

VEGETTI, Mario, Guida alla lettura della Repubblica di Platone. Guide ai classici. Roma: Laterza, 1999.

VERNANT, Jean Pierre (1965). Remarques sur la lutte de classe dans la Grèce ancienne. In: Eirene 4 (1965), 5-19. . (1971) Mito e Pensamento entre os Gregos. Ed. Paz e Terra, 2a edição, 2008. . (1992). Mortals and Imortals. Col Essays. Princeton University Press, 1992. Mito e Tragédia na Grécia Antiga. Ed. Perspectiva, 1999. . As origens do pensamento grego. Ed Difel, 2002. (1996). Entre Mito e Política. Ed. Edusp, 2001.

VERNANT, Jean Pierre \& VIDAL-NAQUET, Pierre (1981). Mito e Tragédia na Grécia Antiga. Ed. Perspectiva, 1999.

VIDAL-NAQUET, P. Les esclaves grecs étaient-ils une classe? In: Raison présente 6 (1968), 103-12.

VIROLI, M. Viroli, M. Rousseau and the 'Well-Ordered Society'. Cambridge University Press, 1988. Machiavelli and the republican idea of politics. In: Machiavelli and Republicanism. Cambridge University Press, 1990. . (1998) Machiavelli. Oxford University Press, 2005. (1998a) O Sorriso de Nicolau. São Paulo: Ed. Estação Liberdade, 2002.

VON FRITZ, K. (1954). The Theory of the Mixed Constitution in Antiquity: a critical analysis of Polybius political ideas. New York: Columbia University Press.

VON VACANO, Diego A. The art of power: Machiavelli, Nietzsche, and the making of aesthetic political theory. Ed. Lexington Books, 2007.

ZINGANO, Marco. A Ética Antiga. Ed. Discurso Editorial, 2007. 